UNIVERSIDADE DE SÃO PAULO

FACULDADE DE FILOSOFIA, LETRAS E CIÊNCIAS HUMANAS DEPARTAMENTO DE HISTÓRIA

PROGRAMA DE PÓS-GRADUAÇÃO EM HISTÓRIA ECONÔMICA

ANDRÉ FILIPPE DE MELLO E PAIVA

\title{
O IMPÉRIO DA FISCALIDADE: \\ UM ESTUDO SERIAL DAS CONJUNTURAS FISCAIS DO ATLÂNTICO PORTUGUÊS (1720-1807)
}

São Paulo 


\title{
O IMPÉRIO DA FISCALIDADE: \\ UM ESTUDO SERIAL DAS CONJUNTURAS FISCAIS DO \\ ATLÂNTICO PORTUGUÊS (1720-1807)
}

\begin{abstract}
Dissertação apresentada ao Programa de Pós-Graduação em História Econômica do Departamento de História, da Faculdade de Filosofia, Letras e Ciências Humanas da Universidade de São Paulo, para a obtenção do título de Mestre.
\end{abstract}

São Paulo

2016 
Autorizo a reprodução e divulgação total ou parcial deste trabalho, por qualquer meio convencional ou eletrônico, para fins de estudo e pesquisa, desde que citada a fonte.

Catalogação na Publicação

Serviço de Biblioteca e Documentação

Faculdade de Filosofia, Letras e Ciências Humanas da Universidade de São Paulo

P142i

Paiva, André Filippe de Mello e

O império da fiscalidade: Um estudo serial das conjunturas fiscais do Atlântico português (17201807) / André Filippe de Mello e Paiva ; orientador Maximiliano Mac Menz. - São Paulo, 2016. $130 \mathrm{f}$.

Dissertação (Mestrado) - Faculdade de Filosofia, Letras e Ciências Humanas da Universidade de São Paulo. Departamento de História. Área de concentração: História Econômica.

1. Fiscalidade. 2. Economia Atlântica. 3. Conjunturas Econômicas. I. Menz, Maximiliano Mac, orient. II. Título. 
Para H., C. e M.(in memoriam), com todo meu amor. 
(...)

Mas não sê tão ingrata!

Não esquece quem te amou

E em tua densa mata

Se perdeu e se encontrou.

$\mathrm{Ai}$, esta terra ainda vai cumprir seu ideal: Ainda vai tornar-se um imenso Portugal!

(...)

Guitarras e sanfonas,

Jasmins, coqueiros, fontes,

Sardinhas, mandioca

Num suave azulejo

E o rio Amazonas

Que corre trás-os-montes

E numa pororoca

Deságua no Tejo...

$\mathrm{Ai}$, esta terra ainda vai cumprir seu ideal: Ainda vai tornar-se um império colonial!

Fado Tropical

Chico Buarque e Ruy Guerra 


\section{AGRADECIMENTOS}

(..)

Fez-se do amigo próximo o distante

Fez-se da vida uma aventura errante

De repente, não mais que de repente.

\section{Soneto de Separação \\ Vinícius de Morais}

Ao terminar a dissertação, e esta é de fato a última parte que faço, depois das revisões mais variadas, das releituras mais detidas, dos pequenos problemas de todo o texto, o momento do agradecimento é aquele que pode conter mais injustiças. Para tentar minimizar esse erro, vou me concentrar naquelas pessoas que estiveram durante todos os três anos de trabalho mais próximas nas horas de desespero em que o texto não saía; quando precisei de chão para tocar a vida com a partida de um amigo; quando do outro lado do Atlântico fizeram a distância parecer menor.

Das relações acadêmicas, não posso deixar de agradecer o prof. Dr. Wilson Barbosa, por ter me dado o privilégio de assistir uma disciplina em que mais do que simplesmente discutirmos a História Econômica do Brasil, discutíamos em grande medida as relações que moldaram nosso país e, por que não, o mundo.

Fundamental neste período de formação, tenho em grande estima o prof. Dr. Pedro Puntoni. A gentileza em todas as vezes que nos encontramos fora do espaço da sala de aula e a deferência sempre dispensada fizeram com que minha admiração fosse mais do que apenas pelo acadêmico. Agradeço também prof. Dr. Fernando Novais pela a chance de ter participado do curso sobre a Nova História.

As contribuições que recebi na Qualificação desta dissertação também foram muito importantes para o resultado a que este trabalho chegou. Agradeço a solicitude do prof. Dr. Wolfgang Lenk e ao prof. Dr. Rodrigo Ricupero por todas as críticas e sugestões.

Sem uma fagulha, lançada quase dez anos atrás, nada disso seria possível. Não fosse a orientação na Iniciação Científica - que fiz com meu amigo Diego Amado, ainda na PUC-SP - da profa. Dra. Lucília Siqueira, que depois fez a gentileza de me apresentar ao meu atual orientador, provavelmente meus caminhos seriam outros.

Não posso deixar de fora a profa. Dra. Vera Ferlini, coordenadora de todas as mesas dos congressos de pós-graduandos que participei nestes anos. O olhar crítico e a 
generosidade das sugestões foram importantes para desobscurecer diversos pontos do que ainda era o projeto. Não posso esquecer também do apoio da Cátedra Jaime Cortesão, quando possibilitou o estágio de pesquisa nos arquivos portugueses. Igualmente agradeço à CAPES, pela bolsa que desde o final de 2013 apoiou esta empreitada.

Na estadia em Portugal, em finais de 2014, tenho a obrigação de agradecer duas pessoas que foram fundamentais no trabalho de pesquisa, sempre dispostas a ajudar no que fosse preciso no Arquivo Histórico do Tribunal de Contas. Não fosse a boa vontade diária do Luis e o apoio institucional dispensado pela diretora, Cristina Cardoso, o período de pesquisa naquele arquivo seria bem menos produtivo. A eles nomeadamente, mas extensível a todos os funcionários, agradeço imensamente.

Dentre todos os agradecimentos a professores, a um deles haveria de ser maior. Foram a paciência e o olhar sempre crítico de meu orientador, prof. Dr. Maximiliano Menz, nesses três anos que fizeram com que essa dissertação saísse. Agradeço por ter mantido ao menos um fio de esperança até nos períodos mais difíceis.

Principalmente nos momentos finais, a análise do amigo Felipe Melo foi de grande importância para fazer com que as ideias que estavam presentes no texto pudessem ser compreendidas e o corte daquelas que não faziam sentido. Não posso esquecer de forma alguma o irmão de batalha Diego Martins. Desde a montagem do projeto, em 2013, foram incontáveis noites em claro que passamos debruçados nos textos. Não fossem todas essas horas de ajuda provavelmente eu não estaria escrevendo estas páginas de agradecimento, pois não haveria dissertação.

Das mulheres da minha vida, começo por aquela que desde a decisão de prestar vestibular para um curso de História esteve sempre pronta a ajudar no que fosse preciso, minha mãe. A ela devo toda a sustentação dos últimos 29 anos, por isso dedico a ela este trabalho. Para Heloisa, que sofreu com as ausências, com a chatice, com o estresse, com a falta de paciência, com a falta de tempo, agradeço por ter aguentado, principalmente nos últimos meses, em que tudo isso foi potencializado. Nestes três anos em que tantas coisas boas aconteceram conosco, estas páginas representam também toda sua ternura comigo. A você também dedico estas páginas.

Por fim, a dedicatória não estaria completa sem uma ausência que tenho sentido todos os dias de um ano para cá. Não consigo expressar em palavras o quanto estas páginas também são suas. Obrigado por tudo, amigo. 


\title{
RESUMO:
}

A dissertação tem por objetivo o estudo das conjunturas fiscais no Atlântico Português por meio da análise dos contratos régios arrematados no Conselho Ultramarino. O recorte cronológico se inicia no ano de 1720, com a centralização das arrematações dos contratos no Conselho Ultramarino e a crescente exploração do ouro, e tem como marco final o ano de 1807, com o fim do exclusivo metropolitano. A pesquisa analisa séries inéditas dos dízimos e dízimas das principais praças coloniais (Bahia, Pernambuco, Rio de Janeiro e Minas Gerais). Por meio do cruzamento desses contratos régios com outros indicadores, como preços e exportações, foi possível concluir a existência de uma conjuntura atlântica comum entre alguns ramos da economia colonial. Os resultados alcançados, por meio da análise fiscal, permitem relativizar e problematizar algumas questões recentes da história econômica colonial, como a plausibilidade de se conjecturar um mercado colonial autônomo das variações externas.

\section{PALAVRAS CHAVE: CONTRATOS; CONJUNTURAS ECONÔMICAS; IMPÉRIO PORTUGUÊS; SÉCULO XVIII; CONSELHO ULTRAMARINO.}

\begin{abstract}
:
This dissertation aims to study the tax conjunctures in the Portuguese Atlantic by analyzing the royal contracts auctioned in the Overseas Council. The chronological cut begins in the year 1720, with the centralization of contracts by public sales in the Overseas Council and the increasing exploitation of gold; finishing in the year 1807 with the end of the metropolitan exclusive. This research analyzes unprecedented series of church tithes and other tithes and taxes of the main colonial squares (Bahia, Pernambuco, Rio de Janeiro and Minas Gerais). By crossing these regal contracts with other indicators such as prices and exports, it was concluded that there is a common Atlantic juncture between some branches of the colonial economy. The results achieved through the fiscal analysis allow us to relativize and discuss some recent issues of colonial economic history, such as the plausibility of conjecture an autonomous colonial market of external variations.
\end{abstract}

KEY WORDS: CONTRACTS, ECONOMIC CONJUNCTURES, PORTUGUESE EMPIRE; EIGHTEEN CENTURY; OVERSEAS COUNCIL. 


\section{SUMÁRIO}

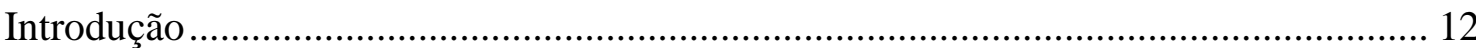

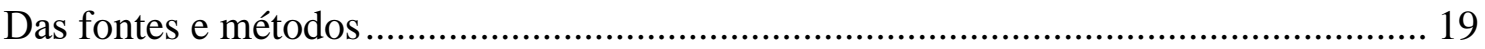

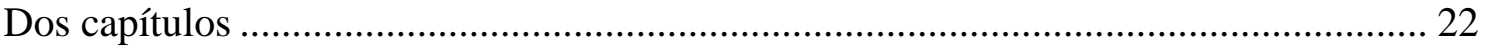

Capítulo I - Poder, Estado e Fiscalidade no Império Português ...................................... 24

Capítulo II - Demanda, Capital e Produção Colonial ...................................................... 44

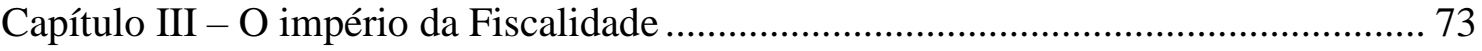

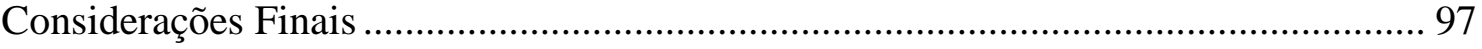

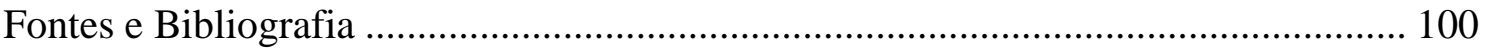

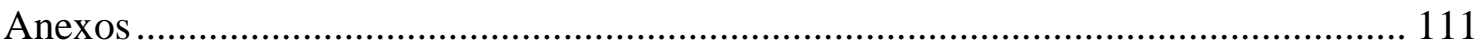




\section{ÍNDICE DE TABELAS}

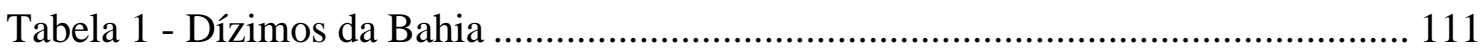

Tabela 2 - Dízima da Alfândega da Bahia.................................................................. 113

Tabela 3 - Dízimos de Pernambuco.............................................................................. 114

Tabela 4 - Dízima da Alfândega de Pernambuco .......................................................... 116

Tabela 5 - Dízimos do Rio de Janeiro ....................................................................... 118

Tabela 6 - Dízima da Alfândega do Rio de Janeiro..................................................... 120

Tabela 7 - Dízimos de Minas Gerais ............................................................................ 122

Tabela 8 - Entradas de Minas Gerais ......................................................................... 125

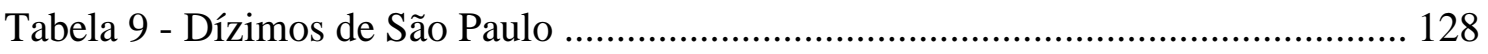

Tabela 10 - Dízimos do Rio Grande de São Pedro do Sul ......................................... 130

\section{ÍNDICE DE GRÁFICOS}

Gráfico 1 - Preço do Açúcar branco em Lisboa (réis/kg) - 1720-1807 ......................... 46

Gráfico 2 - Preço do Açúcar branco em Lisboa (réis/kg) - 1720-1762 ......................... 47

Gráfico 3 - Preço do Açúcar branco na Bahia (réis/kg) - 1720-1762 …....................... 48

Gráfico 4 - Preço do Açúcar branco Bahia x Lisboa - 1720-1762 (índice 1762 = 100) 49

Gráfico 5 - Preço do Açúcar branco no Rio de Janeiro (réis/kg) - 1763-1807 .............. 50

Gráfico 6 - Preço do Açúcar branco em Lisboa (réis/kg) - 1763-1807 .......................... 51

Gráfico 7 - Preço do Açúcar branco Rio de Janeiro x Lisboa - 1763-1807 (índice 1763

$=100$ ).

Gráfico 8 - Preço do Açúcar em Londres, Lisboa e Amsterdã (gramas de prata/kg) 1720-1807

Gráfico 9 - Preço do Açúcar em Londres, Lisboa e Amsterdã (gramas de prata/kg) 1720-1762.

Gráfico 10 - Preço do Açúcar em Londres, Lisboa e Amsterdã (gramas de prata/kg) 1763-1807 55

Gráfico 11 - Remessas de ouro/Imposto 1\% 1720-1807 (em contos de réis)................ 59

Gráfico 12 - Remessas de ouro/Imposto 1\% 1720-1762 (índice 1762=100) .................. 60

Gráfico 13 - Remessas de ouro/Imposto 1\% 1763-1807 (índice 1762=100) ................. 61 
Gráfico 14 - Remessas de ouro/Imposto 1\% provenientes da Bahia, Pernambuco e Rio de Janeiro 1720-1807 (em contos de réis)

Gráfico 15 - Valor das importações na Alfândega do Tabaco de Lisboa (em contos de réis) $1720-1807$

Gráfico 16 - Importações Gerais de Escravos (Bahia, Pernambuco e Rio de Janeiro agregados) 1720-1807

Gráfico 17 - Importações Gerais de Escravos (Bahia, Pernambuco e Rio de Janeiro) $1720-1807$ 68

Gráfico 18 - Importações Gerais de Escravos (Bahia, Pernambuco e Rio de Janeiro) 1720-1807 (por década)

Gráfico 19 - Dízimos da Capitania da Bahia 1720-1807 (em contos de réis) 77

Gráfico 20 - Dízima da Alfândega da Bahia 1720-1807 (em contos de réis) 78

Gráfico 21 - Índices dos preços do açúcar e importação de escravos em relação aos dízimos da Bahia 1720-1807 (1762=100) 80

Gráfico 22 - Dízimos de Pernambuco 1720-1807 (em contos de réis). 82

Gráfico 23 - Dízima da Alfândega de Pernambuco 1720-1807 (em contos de réis) ..... 84

Gráfico 24 - Índices os preços do açúcar e importação de escravos em relação aos dízimos e alfândegas de Pernambuco 1720-1807 (1762=100). 85

Gráfico 25 - Dízimos do Rio de Janeiro 1720-1807 (em contos de réis) 87

Gráfico 26 - Dízima da Alfândega do Rio de Janeiro 1720-1807 (em contos de réis).. 88 Gráfico 27 - Índices do imposto do $1 \%$ do ouro e importação de escravos em relação aos dízimos e alfândegas do Rio de Janeiro 1720-1807 (1762=100) 89

Gráfico 28 - Dízimos de Minas Gerais 1720-1807 (em contos de réis) ........................ 91

Gráfico 29 - Entradas de Minas Gerais 1720-1807 (em contos de réis) 92

Gráfico 30 - Índices do imposto do $1 \%$ do ouro em relação aos dízimos e entradas de Minas Gerais 1720-1807 $(1762=100)$ 93 


\section{Introdução}

O objetivo desta dissertação foi analisar as conjunturas fiscais no Atlântico Português, por meio dos valores de arrematação dos contratos de tributos régios. $\mathrm{O}$ recorte cronológico se inicia no ano de 1720, com a consolidação das arrematações dos contratos no Conselho Ultramarino, e tem como marco final o ano de 1807, com o fim do exclusivo metropolitano. ${ }^{1} \mathrm{O}$ problema de pesquisa pode ser resumido da seguinte forma: existiram relações entre a fiscalidade e a flutuação comercial do Império Português no Atlântico? Em outras palavras, esses dois setores econômicos - um marcado pela extração de renda pelo Estado e outro marcado pela atuação direta do setor privado - conjugavam-se em indicadores passíveis de aproximações? Essa pergunta tem uma implicação historiográfica cara ao debate sobre as relações econômicas entre as colônias e a metrópole, por isso se faz necessário recapitular, brevemente, os pontos principais desse debate para situarmos nosso problema de pesquisa.

A oposição "dependência X autonomia", é um bom ponto de partida para pensarmos o nosso trabalho. Comecemos pelas pesquisas que enfatizaram as ligações entre colônia e metrópole para depois apresentarmos aquelas que procuraram descontruir esse paradigma. Numa das pesquisas mais pioneiras que trataram da economia colonial, Roberto Simonsen sugeriu que o ciclo do açúcar foi a base econômica para a implantação de um sistema colonial na América Lusa, demonstrando reciprocidade entre o comércio açucareiro e o movimento geral da economia portuguesa. Por sua vez, o declínio do comércio do açúcar também esteve ligado a questões exógenas a colônia, como as querelas políticas em que Portugal se encontrava envolvido com outras metrópoles europeias. ${ }^{2}$

\footnotetext{
${ }^{1}$ Este período, marcado pela extração aurífera, traz consigo uma maior organização fiscal-administrativa, com o arrocho das cobranças dos impostos e a instalação de diversas instituições de controle, além da alteração da cabeça da colônia da Bahia para o Rio de Janeiro. A produção do ouro marca certa unidade econômica no período, tanto pelo alargamento do espaço colonial, com o avanço para os sertões, quanto pela integração e fomento a um mercado interno voltado ao abastecimento. Cf. BOXER, Charles R. A idade de ouro do Brasil: dores de crescimento de uma sociedade colonial, 3.ed. Rio de Janeiro: Nova Fronteira, 2000; CARRARA, Ângelo Alves. Minas e currais: produção rural e mercado interno em Minas Gerais 1674 - 1807. Juiz de Fora: Ed. UFJF, 2007; MAXWELL, Kenneth. A Devassa da Devassa: a Inconfidência Mineira, Brasil- Portugal (1750-1808). Rio de Janeiro: Paz e Terra, 1977; PINTO, Virgílio Noya. O Ouro Brasileiro e o Comércio Anglo-português. São Paulo: Cia. Ed. Nacional, 1979.

${ }^{2}$ SIMONSEN, História Econômica do Brasil (1500 - 1820). São Paulo: Companhia Editora Nacional, 1978. p. 176.
} 
Outro marco da historiografia foi Celso Furtado, para o qual a expansão da economia colonial esteve sempre atrelada às diretrizes político-econômicas reinóis. Com a Restauração em 1640, Portugal conquistou sua independência do jugo castelhano, porém perdeu sua principal fonte de lucros, o comércio com o Oriente, e sofreu com as alterações no comércio de açúcar, decorrente da invasão batava no Nordeste. Mesmo com a expulsão dos holandeses em 1654, a crise se acentuou, pois com a perda do monopólio açucareiro e a introdução da cultura canavieira nas Antilhas, houve uma queda brusca nos preços. Furtado sugere uma reversão da economia colonial, que se voltara para a subsistência, no momento de crise econômica. ${ }^{3}$ Como forma de contornar o momento de crise, e ainda envolvido em conflito com espanhóis e holandeses, a solução encontrada pela Corte Portuguesa foi a de se alinhar com a principal potência do período, a Inglaterra. Vários foram os acordos firmados e estes mudaram sobremaneira os vieses políticos e econômicos de Portugal e suas possessões nos dois séculos seguintes. ${ }^{4}$ Com os processos desencadeados pela Restauração, a economia portuguesa, bem como sua colônia na América, se reinsere na economia mundial.

A descoberta das minas vai tornar essa relação ainda mais próxima. Ainda segundo Furtado, o ouro brasileiro fomentou a manufatura inglesa, consolidando a Inglaterra como a principal metrópole da Europa. Já em Portugal, o fluxo de ouro

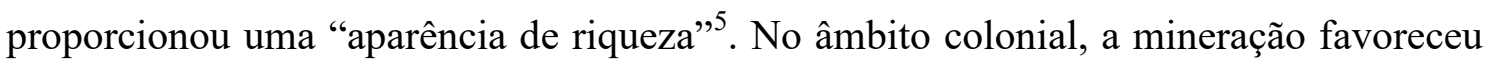
o assentamento demográfico e estimulou a criação de pequenos núcleos organizados de povoação. Também tornou a região propícia ao desenvolvimento urbano e a atividades que proporcionavam o desenvolvimento endógeno. ${ }^{6}$ A interpretação de Furtado é bem clara: a economia colonial estava submetida às flutuações econômicas dos centros metropolitanos. Havia um atrelamento das conjunturas econômicas da metrópole e da colônia. Além disso, Furtado ainda observa que as conjunturas de Portugal e de suas possessões na América estavam também interligadas com a economia inglesa e, desse modo, suscetíveis aos efeitos das variações da economia britânica. ${ }^{7}$

\footnotetext{
${ }^{3}$ FURTADO, Celso. Formação econômica do Brasil. São Paulo: Companhia das Letras, 2007, p. 44.

${ }^{4} \mathrm{O}$ tratado de Methuen, de 1703, foi o mais conhecido, porém outros acordos que contemplavam liberdades econômicas britânicas nas colônias portuguesas já existiam ao menos desde a década de 1640, com o tratado de "Paz e Comércio", avançando, em 1661, com "Paz e Aliança".

${ }^{5}$ FURTADO, Celso. Formação econômica do Brasil... Op. cit., p. 67

${ }^{6}$ Ibidem, p. 119.

${ }^{7}$ Idem, p. 127
} 
Fernando Novais segue as diretrizes básicas do pensamento de Furtado, assim como de outros pesquisadores que não discutiremos neste trabalho. Entretanto, vale assinalar um ponto da análise de Novais, pois foi um dos grandes expoentes da perspectiva dependentista e cujos trabalhos inspiraram muitas pesquisas. A sua grande preocupação é compreender a economia colonial nos quadros mais amplos da transição do feudalismo para o capitalismo. O Antigo Sistema Colonial faria parte desse processo de transição e a acumulação primitiva de capitais por parte da metrópole seria sua característica mais relevante. A análise de Novais não foge da de Furtado, uma vez que as flutuações econômicas da colônia seriam determinadas pela economia europeia. ${ }^{8} \mathrm{~A}$ acumulação de capitais estava entrelaçada ao processo de extração dos excedentes produzidos por formas de trabalho forçado. Além do mais, a própria ampliação das atividades econômicas relacionadas ao mercado interno era subordinada à procura externa. Em suma, para Novais era o setor voltado à exportação que determinava a produção colonial em todas as suas esferas.

Por outro lado, ao contrário dessa perspectiva que enfatiza a dependência dos mercados coloniais para com os mercados externos, temos as interpretações marcantes de João Fragoso e Manolo Florentino. Estes defendem a tese de uma autonomia da economia colonial e, portanto, consideram que as conjunturas locais estariam descoladas do movimento global da economia metropolitana, pois seguiriam ritmos distintos devido à força do mercado interno. ${ }^{9}$ Para Fragoso é indiscutível que a economia colonial se inseria no contexto de transformações ocorridas na Europa. Entretanto, a expansão marítima e a posterior colonização da América se inseriam em uma estrutura arcaizante, de vez que a transferência da renda produzida na colônia para a metrópole corroborou numa sociedade parasitária, consubstanciada em uma hipertrofia estatal e na fusão das atividades mercantis com as senhoriais, como se observa na figura do fidalgo-mercador. ${ }^{10}$

O Estado como empresário da empreitada colonial inibiu a atividade dos agentes privados. Una-se a esse fato o não investimento no desenvolvimento dos setores produtivos - tanto metropolitano, quanto colonial - que contribuíram para a reprodução de uma economia pré-capitalista. A colonização deveria prover a sociedade portuguesa

\footnotetext{
${ }^{8}$ NOVAIS, Fernando. Portugal e Brasil na crise do Antigo Sistema Colonial $(1777-1808)$. $4^{\mathrm{a}}$ ed. São Paulo: Editora Hucitec, 1986, p. 95-96.

${ }^{9}$ Cf. FRAGOSO, João e FLORENTINO, Manolo. O arcaísmo como projeto: mercado atlântico, sociedade agrária e elite mercantil em uma economia colonial tardia: Rio de Janeiro, c.1790-c.1840. Rio de Janeiro: Civilização Brasileira, 2001, passim.

${ }^{10}$ FRAGOSO, João Luís. Homens de grossa aventura. Rio de Janeiro: Civilização Brasileira, 1998.p. 48.
} 
de recursos, que reproduzisse a sociedade e as elites senhoriais. Nesse sentido, a exploração colonial não tinha como fim a acumulação primitiva de capitais, mas sim a reprodução da estrutura arcaizante.

Esses limites da economia lusitana, por outro lado, resultaram em restrições ao sistema de exclusivos, enquanto política de apropriação de excedentes. Assim, haveria uma "autonomia estrutural" que proporcionaria o desenvolvimento de uma produção mercantil de alimentos e o surgimento de uma camada de mercadores residentes nas praças coloniais, que se apropriavam do excedente produzido, fomentando acumulações internas. $^{11}$

Fragoso, juntamente com Manolo Florentino, aponta que esses mercadores residentes constituíram uma verdadeira elite local. A composição da produção colonial contribuía para a formação de mercados de escravos e também de alimentos, que viabilizavam a gênese de um comércio interno, que não estavam relacionados com o centro europeu. A estrutura arcaizante da sociedade colonial proporcionou a constituição de negócios coloniais, que fugiam ao controle metropolitano.

Diferentemente de certa leitura que existia sobre economia colonial, baseada na historiografia clássica, que sugere um atrelamento da economia colonial à economia europeia, os autores apontam para conjunturas locais que não se conectavam ao movimento atlântico de exportação, este sim, engendrado pelas flutuações internacionais. No fim, o significado disso tudo seria a sustentação de estruturas arcaizantes, já que a riqueza acumulada no mercado interno colonial era investida em terras e escravos, procurando demarcar a distinção e a nobilitação social dessas elites. No limite, havia "uma economia capaz de enfrentar com êxito qualquer conjuntura exterior mas que ao mesmo tempo, sofria uma contínua esterilização da riqueza produtiva, promovida por seu próprio capital mercantil." 12

A tese de Fragoso e Florentino sofreu diversas críticas tanto às suas formulações teóricas, quanto às suas demonstrações empíricas, ${ }^{13}$ as quais, adiantamos desde já, compartilhamos. Também há quem tenha sustentado e ampliado o seu paradigma

\footnotetext{
${ }^{11}$ FRAGOSO, João e FLORENTINO, Manolo. O arcaísmo como projeto... Op. cit., p. 231.

${ }^{12}$ Ibidem, p. 162 [grifo nosso]

13 ARRUDA, José Jobson de Andrade. O Império Tripolar: Portugal, Angola Brasil. IN MYRUP, Erik Lars e SCHWARTZ, Stuart (orgs.). O Brasil no império marítimo português. Bauru: Edusc, 2009; SCHWARTZ, Stuart B. Segredos internos: engenhos e escravos na sociedade colonial, 1550 - 1835. São Paulo: Companhia das Letras, 1988.; MENZ, Maximiliano M. Entre impérios: formação do Rio Grande na crise do antigo sistema colonial português (1777 - 1822). São Paulo: Alameda, 2009.; MARIUTTI, Eduardo Barros. Colonialismo, imperialismo e desenvolvimento econômico europeu. São Paulo: Aderaldo \& Rothschild, 2009. (Estudos Históricos; 68).
} 
explicativo. ${ }^{14}$ Outros autores procuraram discutir temas diversos relacionados à economia colonial como, por exemplo, o problema fiscal. ${ }^{15}$

Mais recentemente, Ângelo Carrara desenvolveu a tese do mercado interno para o espaço da mineração. Ao contrário das zonas de produção açucareira, nas regiões de produção aurífera a produção escravista era determinada pelas "demandas geradas pela circulação monetária correspondente à produção do ouro", sua dinâmica não dependia da demanda externa e a determinação da atividade mineradora "era absolutamente interna". De maneira que a economia da mineração não poderia ser entendida pela dependência externa. ${ }^{16}$

Antes de prosseguir, porém, é importante ressaltar que o debate sobre as conjunturas econômicas do Atlântico Português baseou-se em escassas evidências seriais. Simonsen, por exemplo, procurou construir, utilizando fontes quantitativas muito variáveis, uma série da produção açucareira no Brasil, mas ela possui muitas lacunas. Celso Furtado praticamente não utiliza dados quantitativos e tanto Novais, quanto Fragoso e Florentino fazem uso de dados do comércio apenas para o final do século XVIII e início do XIX. Além disso, os defensores da tese da autonomia basearam a sua interpretação exclusivamente no desempenho da economia do Rio de Janeiro, sem considerar os outros contextos coloniais.

Nossa investigação procura justamente subsidiar o debate com a construção de séries baseadas principalmente nos contratos de arrecadação de impostos e que tratam do conjunto do século XVIII, procurando pensar diferentes contextos. Posto isso, nosso trabalho pretendeu responder os seguintes questionamentos: existiria uma conjuntura fiscal do Atlântico? As curvas fiscais do Estado do Brasil seguiriam a mesma tendência dos trends europeus? Existiria uma autonomia relativa nas diferentes capitanias e/ou regiões estudadas?

Estas questões, contudo, não esgotam o problema haja vista a complexidade dos dados que iremos analisar e a diversidade de regiões consideradas. Destacamos que o desenvolvimento da produção exportadora em localidades antes marginais, por um lado

\footnotetext{
${ }^{14}$ GIL, Tiago; PESAVENTO, Fábio. Conversa de surdos: subsídio para o debate sobre o mercado interno. VI Jornada Setecentista. Curitiba, 2005; SAMPAIO, Antonio Carlos Jucá de. Na encruzilhada do império: hierarquias sociais e conjunturas econômicas no Rio de Janeiro (c.1650 - c.1750). 1. ed. Rio de Janeiro: Arquivo Nacional, 2003.

${ }^{15}$ CARRARA, Ângelo Alves, Receitas e despesas da Real Fazenda no Brasil: século XVII, Juiz de Fora: Editora UFJF, 2009; CARRARA, Ângelo Alves, Receitas e despesas da Real Fazenda no Brasil: século XVIII: Minas Gerais, Bahia, Pernambuco, Juiz de Fora: UFJF, 2009; LENK, Wolfgang, Guerra e Pacto Colonial: a Bahia contra o Brasil holandês (1624 - 1654), São Paulo: Alameda, 2013. et al.

${ }^{16}$ CARRARA, Ângelo Alves. Minas e currais... Op.cit., p. 60.
} 
cria mercados e condições de relativa autonomia econômica, seja no espaço deixado pelas crises dos centros produtores tradicionais, seja pela iniciativa de diversificação dos agentes locais. Por outro lado reforça a relação de dependência dos mercados em favor das demandas internacionais dos gêneros coloniais. ${ }^{17}$

A hipótese do trabalho é que o desempenho da agricultura colonial exportadora é resultado de um processo de interação entre a demanda agregada - principalmente a demanda "externa", mas também a demanda gerada pelos mercados internos, estimulados pela produção do ouro - e a "agência local", ou seja, as respostas dos homens de negócio às flutuações na produção local e em outras zonas de produção colonial, bem como das demandas do mercado externo. Essas hipóteses de trabalho constituem um esforço no sentido de se conjugarem tanto os problemas historiográficos que expomos, como os instrumentais conceituais de conjuntura e estrutura. A aproximação desses problemas e conceitos, junto com novos dados possibilitará enriquecer o entendimento sobre algumas questões da economia colonial, principalmente naquilo que toca os assuntos da fiscalidade.

A análise das conjunturas fiscais, isto é, a percepção dos movimentos econômicos, das partes do Império Português se coloca no sentido de apreendermos esses movimentos e os ciclos das arrecadações, associados à atividade econômica, por meio da arrematação dos impostos. Nesse sentido, o nosso recorte cronológico estendido visa à percepção dessas flutuações no longo prazo. Para Fernand Braudel, o aspecto mais representativo a respeito da realidade social da História é a duração social. ${ }^{18}$ No campo da História Econômica os problemas a serem observados são circunscritos por oscilações, que só podem ser analisadas no tempo longo.

Desse modo, para os estudos de longo prazo é necessário que se compreenda dois conceitos chaves: o primeiro deles é a ideia de ciclos econômicos, que tendem a expandir-se e ou se retrair por um determinado quantum de tempo, e que serve de "pano de fundo" para os grandes eventos; em segundo lugar, a noção de estruturas, pois

\footnotetext{
${ }^{17}$ TOMICH, Dale W., Pelo Prisma da Escravidão: Trabalho, Capital e Economia Mundial, tradução Antonio de Pádua Danesi; revisão técnica Rafael de Bivar Marquese. São Paulo: Editora da Universidade de São Paulo, 2011, p. 137.

${ }^{18}$ BRAUDEL, Fernand. Escritos sobre a História. [Tradução J. Guinsburg e Tereza Cristina Silveira da Mota]. - São Paulo: Perspectiva, 2009. - (Debates; 131 / dirigida por J. Guinsburg). p. 43.
} 
servem de sustentáculos e/ou obstáculos dos processos históricos e que são articuladas pelo tempo à longa duração. Os ciclos ocultam permanências e rupturas de determinado tempo social, a partir do momento que os fatos históricos são analisados no tempo mais alongado: é apenas nesta perspectiva que a totalidade histórica pode ser pensada como uma estrutura social.

Para o historiador, tudo se inicia e se termina com o tempo. E o que interessa a ele é o entrecruzamento de movimentos, sua interação e suas rupturas: essas nuances, entretanto, só podem ser observadas em um tempo mais alargado. É a partir desses conceitos, apresentados por Braudel, que cremos que a conjuntura econômica se insere naquilo que pode ser entendido como parte do "movimento social", ou seja, "todos os movimentos que animam uma sociedade, constituindo o conjunto desses movimentos $a$, ou melhor, as conjunturas". ${ }^{19}$

Nesse sentido, Ciro Flamarion Cardoso e Héctor Pérez Brignoli ${ }^{20}$ afirmam que, dos termos fundamentais para o estudo da História Econômica, a conjuntura é o principal deles. Caracterizar-se-ia por mudanças e movimentos dos componentes essenciais da vida econômica, marcada pela recorrência: aos movimentos de alta sucedem os de baixa e assim sucessivamente. Sendo assim, as conjunturas nada mais seriam que a manifestação de um fenômeno estrutural, e porque não dizer das relações sociais. E é a partir desses ciclos, dessas oscilações, que se verificam as crises econômicas.

A conjuntura como um todo, pode agrupar vários ciclos econômicos que vão desde flutuações curtas, como os ciclos sazonais, até aquelas adequadas à longa duração. Destarte, Pierre Vilar aponta que "para a análise histórica, a constatação de uma conjuntura não é um fim. É um dado" ${ }^{21}$. Assim sendo, o exame das conjunturas fiscais apresentadas na arrematação dos contratos é um dado importante para a apreciação da natureza do Império Ultramarino Português no século XVIII, contribuindo assim para entendermos o caráter das relações coloniais.

\footnotetext{
${ }^{19}$ BRAUDEL, Fernand. Civilização material, economia e capitalismo: séculos XV - XVIII: o tempo do mundo, volume 3. São Paulo: Martins Fontes, 1996. p. 59

${ }^{20}$ CARDOSO, Ciro Flamarion \& BRIGNOLI, Héctor Pérez. Os Métodos da História. Rio de Janeiro: Graal, 1983.

${ }^{21}$ VILAR, Pierre. Economía, Derecho, Historia. Barcelona: Editorial Ariel, 1983. p. 17. [tradução nossa]
} 


\section{Das fontes e métodos}

As fontes principais para este trabalho foram os contratos de arrendamento de tributos, instrumento legal utilizado pelo Império Português na arrecadação de impostos régios, transcritos e fichados no projeto do Banco de Dados do Conselho Ultramarino e os documentos originais constantes no Projeto Resgate Barão do Rio Branco. Esse sistema, pelo qual a Coroa entregava a administração de um imposto por tempo limitado a um particular em troca de uma renda, era bastante usual em Portugal e em seus domínios durante o Antigo Regime.

O ponto central de nosso trabalho são as conjunturas fiscais. Considerando a baixa diversificação da economia colonial, temos uma articulação do aparato fiscal com as atividades comerciais. Os homens de negócio que arrematavam os tributos régios estavam fortemente atrelados às atividades comerciais e produtivas. Sendo assim, pretendemos chegar a uma aproximação do movimento econômico real por meio dos arrendamentos. $^{22}$

A utilização dos contratos como fontes, já que esse instrumento de arrecadação de tributos perpassa por diversas áreas econômicas da colônia, possibilita assim uma visão panorâmica das receitas do Império Ultramarino, pois refletem as tendências dos períodos no momento da arrematação. De tal modo, o foco nas arrematações dos dízimos e alfândegas das Minas Gerais, Bahia, Rio de Janeiro, Pernambuco, São Paulo e Rio Grande de São Pedro podem oferecer esse painel.

O uso dos contratos se justifica pela abundância, fiabilidade e solidez desse corpo documental, que por tratar-se de uma produção oficial das contas da Fazenda, confere validade e homogeneidade como fonte, requisitos necessários à investigação serial. $^{23}$ Além dos dados que constam no Banco de Dados, acrescentamos as informações referentes aos contratos arrematados nas provedorias que podem ser encontradas nos Avulsos do Arquivo Histórico Ultramarino (AHU), a documentação

\footnotetext{
${ }^{22}$ Cf. ARAUJO, Luiz Antônio Silva, Fiadores, procuradores e testas de ferro: as redes de negociantes nas arrematações de contratos na América portuguesa no setecentos IN Revista Eletrônica de História do Brasil, v. 10, n. 1 e 2, Jan. - Dez., 2008; Negociantes e contratos régios: o reinado de D. João V (1707 1750), IN “Usos do Passado”, XII Encontro Regional de História ANPUH - RJ 2006;Idem, Contratos e Tributos nas Minas Setecentistas: o estudo de um caso - João de Souza Lisboa (1745-1765). Dissertação de mestrado do Programa de Pós-graduação em História da Universidade Federal Fluminense, Niterói2002; Idem. Contratos, Comércio e Fiscalidade na América Portuguesa (1641-1730) IN CARRARA, Ângelo Alves, SANTIRÓ, Ernest Sánchez (coord.) Guerra e fiscalidade na Ibero-América colonial (séculos XVII - XIX), Juiz de Fora: Ed. UFJF, 2012, p. 260.

${ }^{23}$ Cf. CARDOSO, Ciro Flamarion \& BRIGNOLI, Héctor Pérez. Os Métodos da História... Op. cit., p. 235
} 
que se encontra no Arquivo Histórico do Tribunal de Contas (AHTC, Lisboa) e no Arquivo Nacional da Torre do Tombo (ANTT, Lisboa), especialmente no fundo "Casa dos Contos do Reino e Casa/Erário Régio". Na nova versão do Banco de Dados dos Contratos, foram agregados 137 novos lançamentos, resultantes destas novas fases de prospecção, além de uma mudança na plataforma ${ }^{24}$, visando maior rapidez e facilidade para outros pesquisadores. Além desta nova versão do Banco, de forma anexa a esta dissertação, seguem também no CD-ROM as tabelas com os valores que foram utilizados para a construção dos gráficos e os próprios gráficos, para que possam ser visualizados da forma que o leitor achar mais adequada que a impressa. A estrutura do Banco permite que no futuro se possa disponibilizar de forma online e até mesmo incluir novos dados de forma colaborativa, tal qual o esforço do Transatlantic Slavery DataBase.

Já os demais dados que utilizamos no apoio e na definição das linhas conjunturais dos produtos comercializados, estes são oriundos de diversas séries já publicadas, além de esforços advindos de grupos de pesquisa que disponibilizam dados dos mais variados pesquisadores, já sistematizados.

Os dados coletados para a análise dos movimentos das importações de escravos foram extraídos do Trans-Atlantic Slave Trade Database ${ }^{25}$, Banco de Dados disponível online, que reúne informações quantitativas referentes ao comércio negreiro. Ainda que esta fonte apresente algumas limitações, pensamos que ainda assim constitui fonte inestimável para apreendermos os movimentos mais gerais destas importações. ${ }^{26}$ Com os gráficos que foram elaborados por intermédio dos dados referente ao trato negreiro, tivemos o intuito de apreender os impactos da introdução de africanos escravizados nas variações do movimento da economia, bem como nos momentos de expansão ou retração da produção colonial. ${ }^{27}$

Para tratar dos movimentos do ouro, nos basearemos no imposto do $1 \%$, por meio das bases de dados publicadas recentemente por Leonor Freire Costa, Maria

\footnotetext{
${ }^{24}$ O novo Banco de Dados dos Contratos foi construído em plataforma Access, esforço que não seria possível sem o auxílio de Pablo Oller Mont Serrath. A nova base de dados, com 601 lançamentos totais, teve também revisadas as informações em relação ao "fato gerador" dos contratos e incluída uma coluna em que se pode identificar a qual "capitania/localidade" o contrato se refere (Ver anexo).

${ }^{25}$ Disponível em: http://www.slavevoyages.org/

${ }^{26}$ Para esta análise contei com a generosidade e gentileza do amigo Diego de Cambraia Martins na discussão das origens e funcionamento do Database, e de meu orientador, Maximiliano M. Menz, com a disponibilização das tabelas com os dados.

27 "Desse modo, a escravidão revela a constante assimetria, desigualdade e tensão entre histórias locais particulares e os diversos, porém unificados, ritmos temporais e tensões espaciais dos processos econômicos mundiais.” TOMICH, Dale W., Pelo Prisma da Escravidão...Op. cit., p. 52.
} 
Manuela Rocha e Rita Martins de Sousa. ${ }^{28}$ Foi um imposto criado pela Coroa em 1720 e reza a cobrança de $1 \%$ ad valorem sobre o ouro proveniente do Brasil chegado à Casa da Moeda de Lisboa, contando com remessas tanto de particulares quanto do Estado. Os registros, em Livros Manifesto, cobrem desde sua criação até 1807, data do último Livro $^{29}$.

Utilizamos também outras duas bases de dados, disponíveis online, para a análise das principais praças de comércio: Londres, Amsterdã e Lisboa. Para as duas primeiras, utilizamos as bases disponibilizadas pelo Global Prize and Income History Group - GPIH ${ }^{30}$, de onde extraímos os dados relativos à flutuação dos preços do açúcar em valores relativos ao quilograma do produto por grama de prata. As duas tabelas foram organizadas pelo professor Robert C. Allen. Os dados para a elaboração das tabelas para Londres são oriundos, no período em que nos debruçamos, substancialmente dos seus próprios estudos ${ }^{31}$ e também os de Peter Bowden, que dão conta da História da agricultura na Inglaterra ${ }^{32}$. Para Amsterdã, o professor Allen fez uso dos dados que constam na obra de Nicolaas Wilhelmus Posthumus. ${ }^{33}$ Ambas as tabelas apresentam os dados tanto em seus valores nominais nas moedas locais quanto em quilogramas por prata, valor que aproveitamos para nossas comparações já que a prata poderia ser utilizada como equivalente comum nos valores das três praças comerciais, viabilizando uma análise em conjunto das variações.

\footnotetext{
${ }^{28}$ COSTA, Leonor Freire; ROCHA, Maria Manuela; SOUSA, Rita Martins de, O ouro do Brasil, 17001807, Lisboa, Imprensa Nacional - Casa da Moeda, 2013.

${ }^{29}$ SOUSA, Rita Martins de, Guerra e ouro brasileiro (1720 - 1807) IN CARRARA, Ângelo Alves, SANTIRÓ, Ernest Sánchez (coord.) Guerra e fiscalidade na Ibero-América colonial... Op. cit., p. 337.

${ }^{30}$ Disponível em http://gpih.ucdavis.edu/index.html (acesso em 04/05/2016). Sediado na Davis University of California, o banco sintetiza dados coletados e publicados individualmente por estudiosos, em períodos distintos, e dá conta de um grande espaço geográfico, estendendo-se por todos os continentes e com dados que variam desde valores nominais de produtos até variações de índices mais contemporâneos, como o PIB. Mantido pelos pesquisadores Leticia Arroyo Abad, (Middlebury College) e Peter H. Lindert, (University of California - Davis), o grupo de membros conta com mais de 20 pesquisadores de diversas universidades em todo o mundo.

31 Allen, Robert C., Enclosure and the Yeoman, Oxford: Clarendon Press, 1992. Professor da Universidade de Oxford, estudioso da História Agrária europeia, crescimento econômico, industrialização, levando em conta o caráter da História Global.

${ }^{32}$ Bowden, P., "Agricultural Farm Prices, Farm Profits and Rents", IN J. Thirsk (ed.), The Agrarian History of England and Wales, vol. IV: 1500-1640, London: Cambridge University Press, 1967, pp. 593695.; Bowden, P., "Agricultural Farm Prices, Wages, Farm Profits and Rents", in J. Thirsk (ed.), The Agrarian History of England and Wales, vol. V, part II: 1640-1750, London: Cambridge University Press, 1985, pp.1-118, 827-902.

${ }^{33}$ Posthumus, N.W., Inquiry into the history of prices in Holland, vol.2, Leiden: Brill, 1964. Historiador econômico holandês que publicou o volume I do estudo, que deu origem a nossos dados, durante a Segunda Guerra Mundial.
} 
Para os dados relativos aos preços em Lisboa, utilizamos o banco de dados Prices, Wages and Rents in Portugal - PWR ${ }^{34}$. Todos os valores compilados seguem o mesmo padrão de nossa outra base consultada, trazendo os valores nominais, em réis, e em gramas de prata por quilograma. Os dados referentes ao açúcar até 1768 são provenientes da obra de Stuart Schwartz, que se utiliza dos dados de Dauril Alden, ajustando-os. Para os demais dados, sua origem está nas obras de Rui Lopes ${ }^{35}$ e Nuno Luís Madureira. ${ }^{36}$ Além dos preços do açúcar, o PWR foi fundamental em nossa pesquisa nas consultas aos preços do algodão, tabaco e diversos outros produtos que podem não constar diretamente nesta dissertação, mas que foram consultados para a apreensão deste movimento geral dos preços no Atlântico.

\section{Dos capítulos}

O primeiro capítulo, intitulado Poder, Estado e Fiscalidade no Império Português, apresenta as bases da formação do que podemos chamar de um "Estado Fiscal" na cronologia do Império Português. Para isto, utilizamos como estratégia explicativa uma divisão das estruturas que faziam parte da ossatura do Império no tocante às rendas. Na primeira parte, nos ocupando das composições mais ligadas ao centro do poder, pretendemos aclarar as mudanças administrativas fruto das novas situações referentes à expansão ao ultramar. $\mathrm{Na}$ segunda parte, nos debruçamos sobre “As Estruturas da Periferia", onde discutimos a composição dos órgãos de poder mais locais ou que diziam respeito mais diretamente às administrações locais.

O capítulo tem foco na história política do Império Português e na história administrativa da organização das rendas estatais, tomando como pontos principais os contratos de tributos régios, mais detidamente nos dízimos e contratos da dízima das alfândegas.

\footnotetext{
${ }^{34}$ Disponível em http://pwr.dev.simplicidade.com.pt/000000/1/index.htm e http://pwr-portugal.ics.ul.pt/ (acessados em 04/05/2016). Este projeto foi iniciado em 2009, financiado pela Fundação Portuguesa para a Ciência e Tecnologia (FCT).Um dos seus objetivos foi o de construir uma base de dados de salários, preços e rendas em Portugal entre 1300 e 1910 cobrindo todo o país. Este esforço contou com a participação de diversos pesquisadores, como Inês Amorim (Universidade do Porto), Leonor Freire Costa (Instituto Técnico de Lisboa), Carlos Faisca (Universidade de Lisboa), Helder Fonseca (Universidade de Évora), António Castro Henriques (Universidade do Porto), Conceição Andrade Martins (Universidade de Lisboa), Álvaro Santos Pereira (Simon Fraser University), Jaime Reis (Universidade de Lisboa).

${ }^{35}$ LOPES, Rui , Preços e Salários dos Frades Menores, séc. XVII, Livo 2.

${ }^{36}$ MADUREIRA, Nuno Luís, Consumo, preços e salários (1760-1830) IN Ler História, Lisboa: ISCTE, $n^{\circ} 32$, 1996, pp. 5-32.
} 
Partimos então para a definição das conjunturas gerais dos produtos de destaque no Império Português, com o segundo capítulo, Demanda, Capital e Produção

Colonial. Aqui apresentamos os dados coligidos durante toda a pesquisa em relação ao panorama produtivo da colônia, notadamente a partir das atividades mais proeminentes: o negócio do açúcar, a extração do ouro, o tabaco e o tráfico de escravos.

Assim, os dados foram expostos em blocos temáticos, regionais, cronológicos com corte no período da mudança administrativa mais notável, a transferência da capital de Salvador para o Rio de Janeiro, em 1763, objetivando-se sempre a análise das evoluções da produção, tanto no que diz respeito aos seus valores, quanto em relação às suas regiões.

No último capítulo, que toma o título desta dissertação, O império da Fiscalidade, passamos às análises mais detidas dos movimentos conjunturais de cada localidade e das articulações com a produção que os contratos podem demonstrar. A ideia central foi apresentar um panorama das relações econômicas entre as capitanias e regiões do Estado do Brasil e perceber as mudanças do eixo econômico e de produção, focando sobre as mudanças nos "pesos" de cada região para a economia do Império Português. 


\title{
Capítulo I - Poder, Estado e Fiscalidade no Império Português
}

\author{
"Não há um Estado - mesmo que ainda \\ embrionário ou com uma arquitetura tenteante \\ - sem uma organização financeira." 1
}

A organização administrativa-fiscal do Império Português se deu em um contexto de grandes mudanças ao longo de mais de dois séculos, partindo da Lei Mental, em 1434, até a sistematização do Conselho Ultramarino, em 1642. Os processos desta organização nem sempre seguiram a "linearidade" que acostumamos observar nos projetos políticos contemporâneos. As mudanças de mentalidade, de um contexto medieval para a "racionalidade contábil" " da Época Moderna, ao mesmo tempo em que são inovadoras em seus períodos, refletem questões colocadas nos contextos em que se inserem, apresentando diversos momenta de centralização/descentralização do poder do Estado luso. O presente capítulo pretende oferecer uma visão panorâmica desses períodos, passando pela formação fazendária portuguesa até seus desdobramentos na periferia colonial.

\section{A formação do aparato tributário}

A fiscalidade foi um dos elementos fundamentais na constituição do Império Português e da própria colonização. As colônias e feitorias do ultramar eram parte do patrimônio régio, de maneira que a cobrança de impostos e a exploração dos monopólios eram importantes condicionalismos na expansão econômica e nos modos de integração entre as diferentes partes que compunham a monarquia. Para o traçado da(s) conjuntura(s) fiscal(is) é preciso, portanto, compreender as diferentes variações na administração fiscal e recapitular a constituição da formação do Estado Imperial ${ }^{3}$ em

\footnotetext{
${ }^{1}$ MAGALHÃES, Joaquim Romero, A Fazenda, IN MAGALHÃES, Joaquim Romero (coord.). História de Portugal; No Alvorecer da Modernidade (1480 - 1620), Lisboa: Editorial Estampa, 1997, p. 89.

${ }^{2}$ GODINHO, Vitorino Magalhães, Mito e Mercadoria, Utopia e prática de navegar: séculos XIII-XVIII, Lisboa: Difel, 1990, p. 135.

3 Para este trabalho, utilizaremos a definição formulada por Francisco Bethencourt: "A minha compreensão de Estado imperial não o identifica com a coroa. Envolve a Igreja Católica (com seus diferentes poderes: arcebispos, bispos, capítulos das catedrais, figuras principais das ordens religiosas e beneficiários das igrejas locais, todos nomeados com intervenção ou acordo do rei), a inquisição, os conselhos municipais, as Misericórdias (confrarias protegidas pelo rei que desempenhavam um importante papel na transmissão e execução dos testamentos), e os agentes da coroa, operando em diferentes níveis (Casa da Índia, Conselho do Ultramar, vice-reis, governadores, juízes, capitães, supervisores financeiros e agentes comerciais). Ou seja, inclui todos os mecanismos formais que
} 
Portugal. As modificações efetuadas na transição de uma fiscalidade "medieval", bastante calcada no senhorialismo, podem ser sentidas já por volta do século $\mathrm{XV}$, com a colocação em prática da Lei Mental, de D. Duarte, em 8 de abril de 1434. Por meio desta lei, o Rei retomava diversas propriedades que haviam sido doadas às famílias nobres utilizando-se da estratégia de que as heranças dessas propriedades só poderiam ser gozadas pelo filho mais velho, minando algumas bases do poder senhorial e reforçando o poder da Coroa. ${ }^{4}$

Assim, este reordenamento sobre propriedade senhorial, aliada à criação da sisa, que incidia sobre as transferências de direitos de propriedade, garantia uma forma de rendimento que "permitiu ao Reino português lançar-se na expansão ultramarina." Do ponto de vista institucional, quando em 1551 se incorporaram definitivamente à Coroa a administração perpétua dos mestrados das três ordens militares (de Cristo, de Santiago da Espada e de São Bento de Avis), se nota a consolidação e o aumento do poder régio. Ao Padroado, ressalte-se, não era apenas restrito o governo religioso, mas também o direito de cobrança e administração dos dízimos eclesiásticos. ${ }^{5}$ Veremos com mais vagar ao longo da dissertação a importância que os dízimos possuem na organização das rendas.

Até as primeiras décadas do século XVI os rendimentos da Coroa eram totalmente ligados à ideia de um estado "patrimonial". As rendas eram atreladas às relações senhoriais, que tinham por pressuposto apenas a manutenção da casa nobre e das estruturas locais, ou seja, não eram vistas exatamente como "rendas do rei", mas réditos que eram circunscritos aos governos locais, apenas frouxamente submetidos ao poder real. Não foi de forma imediata que se conseguiu separar tudo o que era público e privado, processo que se deu ao longo da construção do Estado moderno. ${ }^{6} \mathrm{~A}$ organização dos tributos também não se deu de modo repentino. Não obstante, podemos tomar como ponto de partida a ideia de que

(...) tributo é tudo o que deve ser, por costume, pago ao príncipe (tributum esse omne illud quod principi solui debet), considerado quer

mantinham um "firme controlo sobre a vida das pessoas" (como diria Botero), exerciam o monopólio legítimo da violência e regulavam os conflitos sociais." BETHENCOURT, Francisco, Configurações Políticas e Poderes Locais IN BETHENCOURT, Francisco e CURTO, Diogo Ramada (orgs.). A expansão marítima portuguesa, Lisboa: Edições 70, 2010, p. 210.

${ }^{4}$ SALGADO, Graça (coord.). Fiscais e Meirinhos: a administração no Brasil Colonial. Rio de Janeiro: Nova Fronteira; Brasília: INL, 1985, p. 27.

${ }^{5}$ Ibidem, p. 113.

${ }^{6}$ MAGALHÃES, Joaquim Romero, A Fazenda... Op. cit., p. 89. 
por sua arrecadação, quer quanto aos fins do seu emprego (...) o tributo supõe, com efeito, que numa comunidade (res publica) se dê a separação do poder público face aos particulares (a cousa privada), que deste modo vêem diferenciar-se de si o príncipe, detentor dessa republicae potestas. ${ }^{7}$

Desse modo, podemos perceber que a partir do século XVI, houve um movimento de consolidação do Estado Português, com a tentativa de unificação físcal através da sisa, genérica a toda comunidade, ou como sugeriu Vitorino Magalhães Godinho, um tributo universal. A noção da "comunidade", que define o Estado, seria a transposição "à escala nacional de uma maneira de encarar uma realidade social coletiva à escala local - é como que a noção de 'concelho' alargada a todo o reino."8 A cobrança da sisa demandava novas formas de contabilização, com a inserção definitiva dos algarismos arábicos, além de salientar a importância do comércio, já que este imposto estava restrito às movimentações de mercadorias. ${ }^{9}$

Mais ou menos no mesmo contexto ocorreu a reforma nas cartas de foral por D. Manuel I. As cartas de forais eram um tipo de documento oficial, concedido pelo rei ou senhorio laico ou eclesiástico, que disciplinava a relação entre os povoadores ou habitantes de determinada terra entre si e a entidade que lhes outorgava esses direitos. ${ }^{10}$ Ao mesmo tempo em que demonstrava a vontade do rei em povoar o Reino, confirmava também sua autoridade em relação a estes territórios e em relação às rendas que advinham dessas terras.

As mudanças no regime de foral resultavam em alguns desdobramentos do ponto de vista das relações entre rei e súditos. Desde ao menos 1481, já havia reclamações em relação às mudanças nas outras relações jurídicas empreendidas ao longo do século. Nesse sentido, o fortalecimento do poder real, bem como a padronização jurídica que fora alcançada através da legislação geral, fizera com que as antigas instituições de raízes medievais se enfraquecessem. ${ }^{11}$ A reforma dos forais, no reinado de D. Manuel I dotou a Coroa de novos instrumentos de controle, o que possibilitava gerenciar melhor as rendas, bem como unificar institucionalmente uma série de cargos da

\footnotetext{
${ }^{7}$ GODINHO, Vitorino Magalhães, Finanças públicas e estrutura do Estado, IN Dicionário de Historia de Portugal, vol. 3, Porto: Iniciativas Editoriais, 1971, p. 244.

${ }^{8}$ GODINHO, Vitorino Magalhães, Finanças públicas...Op. cit., p. 255, MENZ, M., Notas.

${ }^{9}$ MENZ, M., notas de aula (10).

${ }^{10}$ COSTA, Mário Júlio de Almeida, Forais, IN Dicionário de Historia de Portugal, Porto: Iniciativas Editoriais, vol. 3, 1971, p. 279

${ }^{11}$ Ibidem, p. 280
} 
administração. ${ }^{12}$ Ao mesmo tempo em que a Coroa se via com a necessidade de delegação dos poderes nas posses, dada a distância do poder central, para assim poder garantir a execução de suas ordens, cai em um paradoxo, pois "perde a força do 'Mando', ficando apenas com a supremacia teórica do Poder."13

Assim, desde as reformas empreendidas no século XV e ao longo do Antigo Regime o que se viu foi uma dominação da estrutura política por uma "pulverização" do poder administrativo para corpos inferiores. A demanda por novas formas de governo, devido ao alargamento das fronteiras do espaço de mando, aumenta de forma exponencial. Se antes apenas com as freguesias, calcadas no pequeno espaço e na municipalidade, a Coroa dava conta da administração, com a formação do Império isso não se mostra mais possível. Quando ampliamos esta questão para os espaços Ultramarinos o que podemos perceber em algumas ações é que ainda que o poder continue a emanar do centro, os poderes locais gozam de certos filtros para execução das decisões. ${ }^{14}$

\section{Os corpos institucionais}

A analogia ao corpo humano para explicar o exercício do poder, advém da concepção organicista, vinda do século XVI, onde as partes tinham suas funções, com o Rei representando a cabeça do reino, coordenador dos "órgãos" - conselhos, tribunais, ministros, oficiais - que seriam prolongamentos de seu corpo. Através desses prolongamentos que o Rei instrumentalizava sua ação política. ${ }^{15}$

Ao rei, e aos demais órgãos, competiam funções definidoras e "naturais" que deveriam desempenhar, cabendo ao monarca o papel de "centro coordenador", o que para além das funções de garantir harmonia, paz e segurança, em outras palavras, "fazer

\footnotetext{
${ }^{12}$ A reforma dos forais, no reinado de D. Manuel dota a Coroa de novos instrumentos de controle, o que possibilita gerenciar melhor as rendas, bem como unifica institucionalmente uma série de cargos da administração. COSTA, Leonor Freire, LAINS, P., MIRANDA, S. M., História Económica de Portugal, 1143-2010. Lisboa: Esfera dos Livros, 2014, p. 126

${ }^{13}$ MENZ, M., notas de aula (11); VICENS VIVES, J. Estructura administrativa estatal en los siglos XVI y XVII, 1961, p. 109, Apud MAGALHÃES, Joaquim Romero, O Algarve Econômico, 1600-1773, Lisboa: Estampa, 1993, p. 324

${ }^{14}$ MAGALHÃES, Joaquim Romero, O Algarve Econômico...Op. cit., p. 325

${ }^{15}$ GARCÍA MARÍN, José M., La burocracia castellana bajo los Austrias, Madrid, INAM, 1986; HESPANHA, António Manuel, História das Instituições. Épocas medieval e moderna, Coimbra: Almedina, 1982; HESPANHA, António Manuel, Poder e instituições no Antigo Regime, Lisboa: Cadernos Penélope, Lisboa: Cosmos, 1992, pp. 31-57 Apud SUBTIL, José, A administração central da coroa IN MAGALHÃES, Joaquim Romero (coord.). História de Portugal; No Alvorecer da Modernidade (1480 - 1620), Lisboa: Editorial Estampa, 1997, p. 76; KANTOROWICZ, Eric. Os dois corpos do Rei: Um estudo sobre a teologia política medieval. São Paulo: Companhia das Letras, 1998, passim.
} 
justiça". Imanente a esta função estava a de "evitar a intromissão de funções e competências entre os diversos órgãos político-administrativos". ${ }^{16}$

De acordo com José Subtil, a área de poder do príncipe corresponde ao que podemos chamar de "administração da coroa". No século XVI já seria possível identificar ao menos três grandes áreas de ação: justiça, fazenda e milícia. À área da justiça, de central importância nesta concepção jurisdicionalista de poder, podemos agrupar os órgãos ordinários do governo (tribunais, conselhos, magistrados e oficiais), ou seja, todas as questões em que se colocava à prova ou que necessitava intermediação para garantia dos equilíbrios sociais. Esta área acabava por sobrepor-se de certa forma às outras, já que "aos vários 'corpos' que coexistiam no rei aplicavam-se várias imagens: a de 'senhor da justiça e paz', a de 'chefe da casa' (de grande 'economo'), 'protetor da religião' e 'cabeça da república'.,"17

Aos finais do século XVI, algumas funções ganharam certa autonomia no processo administrativo português. Alguns órgãos foram de fato institucionalizados. Observamos o surgimento dos tribunais e conselhos, o que em última análise configura o que podemos chamar de "matriz do Antigo Regime"18. Notavelmente, nesse sistema "a malha da rede administrativa tinha os seus pontos de apoio no sistema municipal"19. As Câmaras municipais desempenhavam papel com relativa autonomia financeira e também completavam esse quadro de mudanças pós-manuelinas, já que suas funções de administração e justiça situavam-se mais próximas à comunicação política entre os vassalos e seus secretários, estes últimos que auxiliavam nestes processos com os tribunais e conselhos.

Deste modo, o que a historiografia chama de "regime polissinodal" seria um conjunto de instituições com funcionamento colegiado, em que cada uma de suas partes serviria tanto para aconselhamento do rei, quanto para unidades de poder auto regulatórias em questões de tribunal ou governo. Esse conjunto de organismos burocráticos dava origem a novas instituições ou instigavam a reforma das existentes.

\footnotetext{
${ }^{16}$ SUBTIL, José, A administração central... Op. cit., p. 75.

17 SUBTIL, José, Governo e Administração, IN HESPANHA, Antônio Manuel, História de Portugal; O Antigo Regime (1620 - 1807), Lisboa: Editorial Estampa, 1998, p. 141.

18 NEVES, Guilherme Pereira das, VAINFAS, Ronaldo, Antigo Regime IN VAINFAS, Ronaldo (org.), Dicionário do Brasil Colonial (1500 - 1808), Rio de Janeiro: Objetiva, 2001, pp. 43, 44.

${ }^{19}$ BELLOTTO, Heloísa Liberalli, O Estado Português no Brasil: Sistema Administrativo e Fiscal, IN SILVA, Maria Beatriz Nizza da, Nova História da Expansão Portuguesa; O Império Luso-Brasileiro (1750 - 1822), vol. VIII, Lisboa: Editorial Estampa, 1992, p. 280
} 
Em cada área de competência, administravam e tomavam decisões como órgãos superiores hierarquicamente à administração periférica. ${ }^{20}$

Sendo assim, as figuras de funcionários régios como, por exemplo do "Escrivão da puridade" (quando existiu) e dos "Secretários da câmara e despacho", eram bastante importantes já que materializavam e asseguravam a coordenação da atividade governativa, simbolizada e representada pelo rei, sobretudo no período pós-manuelino. ${ }^{21}$ Os tribunais, a Casa da Suplicação, as Relações do Porto, da Índia e do Brasil, além do Desembargo do Paço eram instituições com poderes independentes entre si, estando subordinados apenas à Coroa, assim como os Concelhos da Fazenda, do Estado, Mesa de Consciência e Ordens, Índia e Portugal, todos já consolidados em finais do século XVI e princípios do XVII. Portanto, podemos representar a Coroa como um centro emanador do poder representado na figura do rei, orbitado por diversas instituições de funcionamento de certa forma autônomas umas das outras, ou seja, com certa independência administrativa.

\section{A Fazenda}

O processo de especialização dos ofícios de Estado ocorreu em vários estágios. Primeiramente, surgiram os vedores, ainda por volta do século $\mathrm{XV}$, ligados ao Desembargo Régio. Estes, no início do século XVI passaram a contar com basicamente três vedorias (Reino, África e Contos e Índia) e tinham como principais competências o arrendamento das rendas e todas as atividades que poderiam depreender-se desta, como a confirmação dos aforamentos, provimento de ofícios, resolução de conflitos por via litigiosa, além de toda a escrituração contábil. ${ }^{22}$

Durante o período filipino, sobreveio o último estágio dessa evolução administrativa, com a criação do Conselho de Fazenda, nos finais do século XVI. A importância destes órgãos do ponto de vista político e institucional foi de grande monta, já que foi a partir dessas mudanças que se pôde demarcar a efetiva especialização dos cargos, opondo de forma mais clara os "financeiros e juristas". ${ }^{23}$ A estas mudanças, some-se a instituição em 1508, do cargo de provedor, função ampliada do cargo de contador, que também respondeu a este alargamento dos processos de controle criados

\footnotetext{
${ }^{20}$ SUBTIL, José, A administração central... Op. cit., p. 76.

${ }^{21}$ Ibidem.

${ }^{22}$ Idem, p. 81.

${ }^{23}$ Idem, p. 80 .
} 
pelo Estado Português. A dilatação das funções do cargo dos contadores demonstrou o ganho de valor desses procedimentos de controle contábil, ainda mais quando percebidos o incremento de importância das alfândegas, seja na obtenção ou no controle das rendas, principalmente nos quadros administrativos do Ultramar. ${ }^{24}$

A criação, em 1514, da Casa dos Contos do Reino como órgão centralizador da contabilidade parece ser de fundamental importância para essa reorganização das rendas portuguesas. Integrando a fiscalização de uma série de contadorias espalhadas pelo Reino. Mais do que simples organismo de fiscalização, este órgão figurou entre os mais importantes da administração, tendo subordinados a si os cargos relacionados à Fazenda: Provedor-Mor, Contador-Geral, Tesoureiro, Juízes dos Feitos de Fazenda, Procurador dos Feitos da Coroa e Escrivães. Mas não só. Subordinava também os cargos referentes às Alfândegas: Provedor/Juiz da Alfândega, Almoxarifes, Escrivães, Rendeiros/Contratadores, Porteiro, Guarda. Procurava-se exercer uma fiscalização mais rígida sobre a administração local, que tomava formas mais complexas de organização, o que dificultava a informação dos oficiais e seus cargos. Podemos perceber esse processo quando se funde a Casa dos Contos de Lisboa, em 1560, que fiscalizava a conta dos oficiais que atuavam no Reino, tornando clara a centralidade deste tribunal frente à Fazenda Real. ${ }^{25}$

Em 1580, ocorre a União das Coroas e com isso a integração dos organismos portugueses nas lógicas das instituições espanholas. Não houve uma integração total e irrestrita dos processos, o que acarretou em não haverem mudanças substantivas nestes dispositivos. ${ }^{26}$ Essa crescente "especialização" no auxílio das tomadas de decisão pode nos colocar frente a um paradigma: a crescente especialização da burocracia e dos ofícios satisfez um processo de centralização política, ao mesmo tempo em que o estímulo a esta especialização fortalece as instituições políticas e com isso pulveriza o exercício do poder, contrariando os propósitos de centralização política. ${ }^{27}$

Por sua vez, a criação do Conselho de Fazenda, em 1591, extinguiria as três vedorias e se colocaria então como última instância de recurso aos "feitos de fazenda". ${ }^{28}$ Os procedimentos então ligados aos contratos de arrendamento, assim como as tenças, passaram à jurisdição deste tribunal. Assim sendo, tinha também a seu cargo a inspeção

\footnotetext{
${ }^{24}$ PUNTONI, Pedro, O Estado do Brasil: Poder e Política na Bahia Colonial 1548 - 1700, São Paulo: Alameda, 2013, p. 117.

${ }^{25}$ Ibidem.

${ }^{26}$ Idem.

${ }^{27}$ SUBTIL, José, A administração central... Op. cit., p. 77.

${ }^{28}$ Ibidem, p. 82.
} 
dos livros de tombo, bem como autorizava o despacho de naus e armadas da Índia. Para evitar a acumulação de dívidas e possibilidades de fraude, a Coroa optou por um tipo de governo sinodal, agregando num único centro o controle de receitas e despesas. Para além da função jurisdicional, uma das funções que lhe tocava, em "termos de jurisdição voluntária", era a de fiscalizar os contratos de arrendamento de recolhimento de impostos. $^{29}$

Com a Restauração Portuguesa, em 1642 foi criado o Conselho Ultramarino, uma "remodelação" da Casa da Índia, criada por Filipe II durante o período da União Ibérica. Seguindo os moldes de seu antecessor, o Conselho Ultramarino tinha como atribuição uniformizar a administração do ultramar lusitano, tratando sob o mesmo teto de todas as posses e colônias. Sua composição era típica do Antigo Regime, sendo formado por três conselheiros, dois fidalgos de guerra e um letrado. O conselho era responsável sobre os negócios relativos aos estados do Brasil, Índia, Guiné, ilhas de São Tomé e Cabo Verde e demais partes ultramarinas da África. A atribuição de cargos, exceto os eclesiásticos, providos pela Mesa da Consciência e Ordens, também era uma de suas funções. Como órgão tradicional do Antigo Regime, o critério de seleção de seus presidentes era a titulação de fidalguia e a experiência nos negócios do ultramar. Desse modo, o Conselho Ultramarino passou a abarcar certas funções que antes pertenciam ao Conselho de Fazenda, centralizando assim os assuntos relativos às colônias ultramarinas. ${ }^{30}$

\section{Estruturas da Periferia}

As estruturas de poder, nas regiões periféricas do Império Português, seguiam alguns padrões da administração que já existiam no Reino, como por exemplo, a municipalidade e a atuação das câmaras; entretanto, houve certas inovações, como as capitanias donatárias. À expressão governativa da municipalidade estava ligada a ideia de "extensão da metrópole", em que a Coroa, ao invés de criar novas estruturas para exercer sua governação, apenas traspassava as já existentes aos novos territórios. ${ }^{31}$

\footnotetext{
${ }^{29}$ Idem, p. 82-3.

${ }^{30}$ CF. GOUVÊA, Maria de Fátima Silva. Conselho Ultramarino. IN VAINFAS, Ronaldo (organizador). Dicionário do Brasil colonial (1500-1808). Rio de Janeiro: Objetiva, 2001.

${ }^{31}$ Este tema foi desenvolvido por diversos autores, os quais podemos destacar: FAORO, Raymundo, $O s$ Donos do Poder: formação do patronato político brasileiro. 5. ed. (1 ed. 1958) - São Paulo: Globo, 2012; SALGADO, Graça (coord.), Fiscais e Meirinhos... Op. cit. e PRADO JUNIOR, Caio, Formação do Brasil Contemporâneo: Colônia. 1 ${ }^{a}$ Edição - São Paulo: Brasiliense; Publifolha, 2000 (Grandes nomes do pensamento brasileiro).
} 
Como já apontado, basicamente a estrutura judicial e administrativa portuguesa era o Conselho. Assim o era também nas partes periféricas do Império, como por exemplo, a tradição ibérica da instalação de pelourinhos em toda cidade portuguesa seja no Reino, seja no Ultramar - a fim de castigar os criminosos, sendo ele o maior símbolo governamental concernente à justiça. ${ }^{32}$

A América Portuguesa, até o segundo quartel do século XVI, não passava de território extrativista e sem grande relevância econômica, já que neste período Portugal estava completamente envolvido com seu Império no Oriente, que destacava-se por suas possibilidades comerciais e estratégicas. ${ }^{33}$ Assim, apenas em 1530, com a expedição de Martin Afonso de Sousa - intitulado "capitão-mor da armada e capitão-mor das terras do Brasil”, explicitando as faces militar e civil, tidas como inseparáveis pela Coroa $^{34}$ houve alguma mudança no estabelecimento mais efetivo da colonização brasileira.

A colonização demandava soluções não só na esfera econômica, mas também do ponto de vista jurídico e militar. Em resposta a um possível interesse francês nas terras da colônia americana, D. João III se mostrou favorável à instituição das capitanias donatárias, observando as experiências que a Coroa já experimentava nos arquipélagos atlânticos. ${ }^{35} \mathrm{O}$ sistema da distribuição das capitanias era marcado por sua simplicidade: certa porção de terra era atribuída a um donatário, de forma hereditária, que era a autoridade jurídica em sua extensão, podendo utilizá-la também de acordo com seus interesses pessoais. A estes direitos era ainda garantida a nomeação de um ouvidor, bem como de alcaides. Os rendimentos dos donatários seriam oriundos das receitas do paubrasil, da redízima, da vintena do peixe, bem como dos tributos das barcas. ${ }^{36}$

Com o estabelecimento das capitanias, foi natural que surgissem as primeiras vilas e com estas as câmaras. Responsáveis pelo governo no âmbito local, estas possuem papel fundamental nos modos de governar português e se inserem de certa forma na lógica da governabilidade. Podemos dizer que a ocupação do território

\footnotetext{
${ }^{32}$ SCHWARTZ, Stuart B., Burocracia e sociedade no Brasil colonial: o Tribunal Superior da Bahia e seus desembargadores, 1609 1751, São Paulo: Companhia das Letras, 2011, pp. 27-8.

${ }^{33}$ Sede do poder Imperial na Ásia desde 1510, Goa irradiava a presença portuguesa para o Oriente e era um ponto de importância comercial desde os árabes. Durante o séculos XVI e XVII, o Império do Oriente foi o maior responsável pelas grandes aferições de renda da Coroa, o que mudará de figura apenas no século XVIII com o crescente aumento de importância do Atlântico. Não obstante, o leste ainda foi muito lucrativo durante todo o período de presença portuguesa. SCHWARTZ, Stuart B., Burocracia e sociedade no Brasil colonial... Op. cit., pp. 38, 41.

${ }^{34}$ RICUPERO, Rodrigo, A formação da elite colonial: Brasil, c.1530-c.1630, São Paulo: Alameda, 2009, p. 135.

${ }^{35}$ CARVALHO, Filipe Nunes de, Do Descobrimento à União Ibérica, IN JOHNSON, Harold e SILVA, Maria Beatriz Nizza da, Nova História da Expansão Portuguesa, O império Luso Brasileiro (1500 1620), vol. VI, Lisboa: Editorial Estampa, 1992, p. 114, 115.

${ }^{36}$ Idem, p. 115
} 
americano pelos colonos era restrita, em partes, ao litoral. A entrada para o interior da capitania era de fato difícil e demandava grandes capitais, além de uma quantidade considerável de mão de obra para tal, já que transpor as barreiras naturais e o encontro com as populações nativas hostis, muitas vezes produziam um ambiente insalubre aos europeus que tentavam instalar-se. Porém, “em geral, o sistema de donatários no Brasil mostrou-se tão ineficiente na administração da justiça como na promoção da colonização. $^{, 37}$ Grande parte dos donatários não possuía experiência administrativa/judicial, apenas militar, já que a maioria provinha da pequena nobreza.

A saída, ainda no governo de D. João III, foi instituir a centralização do governo do Brasil na figura do Governador-Geral. ${ }^{38}$ Tomé de Souza foi seu primeiro ocupante em 1549. Além de atuar na defesa dos interesses locais, esta forma de governo em capitanias também atuava como afirmadora e mantenedora das determinações régias, pretendendo a defesa dos interesses dos colonos estabelecidos, tidos pela Coroa como elementos fundamentais para o desenvolvimento econômico colonial. ${ }^{39}$

No que toca as atividades de Justiça e Fazenda, o Governador-Geral trouxe consigo as figuras do ouvidor geral e do provedor-mor. Ambos os cargos tinham como prerrogativa coordenar e fiscalizar as atividades dos provedores, ouvidores e de outros oficiais que atuavam localmente nas capitanias. ${ }^{40}$ Esses cargos vão ganhando em importância, a partir do momento que a América Portuguesa passa a ter peso nas rendas imperiais. ${ }^{41}$ Não podemos nos esquecer, que "a presença do governo-geral orientava de maneira decidida a empresa colonial - de acordo com os interesses dos poderes do centro e dos interesses localmente negociados pelos próprios mandatários." ${ }^{42}$

\footnotetext{
${ }^{37}$ SCHWARTZ, Stuart B., Burocracia e sociedade... Op. cit., p. 44

38 RICUPERO, Rodrigo, A formação da elite colonial... Op. cit., p. 137. "Em resumo, a ocupação portuguesa viabilizou-se por um conjunto de ações, de instituições herdadas do repertório ibérico, mas que adquiriram sentido próprio e específico na América. Assim foram as sesmarias, as capitanias e as câmaras." FERLINI, Vera Lucia Amaral O município no Brasil colonial e a configuração do poder econômico IN MELLO E SOUZA, Laura de, FURTADO, Júnia Ferreira, BICALHO, Maria Fernanda (orgs.), O governo dos povos, São Paulo: Alameda, 2009, p. 393. "A abordagem da economia da América Portuguesa, na perspectiva do Antigo Sistema Colonial, coloca como relação dominante de exploração a que se estabelece, na diacronia, entre a metrópole e a colônia, como interação dialética entre a condição colonial e as expressões sociais específicas, o que permite a compreensão tanto do processo global como dos movimentos particulares." FERLINI, Vera Lucia Amaral, O município no Brasil colonial... Op.cit., p. 392.SCHWARTZ, Stuart B., Burocracia e sociedade... Op. cit., p. 44.

${ }^{39}$ FERLINI, Vera Lucia Amaral, O município no Brasil colonial... Op.cit., p. 392.

${ }^{40}$ RICUPERO, Rodrigo, Op. cit., p. 139.

${ }^{41}$ MENZ, M., notas de aula (11)

${ }^{42}$ PUNTONI, Pedro, “Como coração no meio do corpo": Salvador capital do Estado do Brasil , IN MELlO E SOUZA, Laura de, FURTADO, Júnia Ferreira, BICALHO, Maria Fernanda (orgs.), $O$ governo dos povos... Op. cit., p. 373.
} 
Figura de relativa importância no Reino, o provedor ao transcorrer dos anos de mil e seiscentos alcançou papel central nas relações e nas dinâmicas do Império. "Da 'fazenda dos ausentes', o provedor passa cada vez mais a cuidar da Fazenda real." ${ }^{\text {,4 }}$ Com suas funções no ultramar ampliadas, controlando sobretudo a cobrança de impostos, a provedoria desempenhava papel fundamental na administração das receitas e despesas coloniais tornando-se, ao longo do século XVIII, a máquina burocrática das periferias mais especializada no âmbito fiscal. Sob sua supervisão era arrematado o tributo mais importante do século XVII: o dízimo. Importante ressaltar que "até 1628, os dízimos eram arrematados em massa, isto é, por todo Estado do Brasil”44. A partir daí, as arrematações passaram a ser feitas por capitanias.

Assim, as câmaras, ao menos durante o século XVII, tinham a função da administração das rendas e da garantia do cumprimento das ordens no âmbito local. Entretanto, as invasões holandesas e a crise da Dinastia Filipina, deu às câmaras a iniciativa na criação de rendas e na administração de uma boa parte do esforço de guerra, o que conferia grande poder aos camarários. ${ }^{45} \mathrm{Na}$ segunda metade do século XVII, porém, com o crescente do protagonismo do Conselho Ultramarino aumentam os conflitos com a gestão dos recursos do Império. Um ponto de inflexão nesta querela, ao menos no que toca as rendas, se dá na centralização das arrematações dos contratos no Conselho Ultramarino na década de 1720.

\section{Fiscalidade e Administração no século XVIII}

A maior parte dos impostos no Império Português era arrendada a particulares. A arrematação de tributos não foi uma invenção da administração portuguesa e remonta ao Império Romano. Obviamente reelaborada e ressignificada, a arrecadação pública por meio da celebração de contratos - surgindo com isso a figura afamada do contratador foi central nas rendas Reais portuguesas. Podemos entender os arrendamentos como uma técnica auxiliar no planejamento das finanças, pois as arrematações teoricamente "garantiriam" os rendimentos e dariam melhores resultados, no que respeita à previsibilidade do ponto de vista orçamentário, em comparação ao cenário difuso das

\footnotetext{
${ }^{43}$ PUNTONI, Pedro, O Estado do Brasil... Op. cit., p. 117

${ }^{44}$ Ibidem, p. 121; CARRARA, Ângelo Alves, Receitas e Despesas da Real Fazenda no Brasil: século XVII... Op. cit., p. 39.

${ }^{45}$ Sobre esta questão, formação do aparato camarário na Bahia e as formas de tributação para sustento da capitania ver LENK, Wolfgang, Guerra e pacto colonial... Op. cit. p. 323-68.
} 
administrações diretas, que demandaria grande esforço da funcionalidade régia. ${ }^{46}$ Os arrendamentos de impostos foram bem sucedidos na sustentação financeira do Império. Independentemente das críticas a esta forma de administração, tão comuns no decorrer do século XVIII, o seu resultado, no geral, foi positivo.

As posses da Ásia caminhavam para a autossustentação financeira. Os rendimentos das alfândegas de Goa, Malaca, Ormuz e Diu já respondiam muito bem às necessidades orçamentárias locais, como as despesas militares, eclesiásticas e navais. ${ }^{47}$ Para o espaço Atlântico observaremos o mesmo. A divisão em capitanias previu justamente a sustentação de cada localidade com suas próprias formas de rendimento e arrecadação. Cada unidade deveria ser capaz de administrar-se com suas próprias receitas, mesmo depois da instituição do Governo Geral. A conquista e criação de um governo geral em Angola replicaram no outro lado do Atlântico-sul este sistema: governador geral, provedor e ouvidor passaram a governar o patrimônio régio no litoral africano, com o grosso das rendas produzido pelo imposto sobre a exportação de escravos.

Seja como for, do ponto de vista fiscal, no século XVII o Império mais valia pelas contribuições arrecadadas nas alfândegas portuguesas, do que pelas remessas líquidas das provedorias coloniais que parecem ter sido inexistentes. ${ }^{48}$ Mas as elites mercantis e senhoriais portuguesas ganharam um bom dinheiro na Ásia e no Atlântico, participando do comércio de longa distância e ocupando cargos e postos de administração. Assim, mais do que mudanças no processo produtivo português, o que ocorre durante o século XVII é uma crescente integração entre os domínios portugueses no Ultramar. ${ }^{49} \mathrm{~A}$ articulação entre produtos de luxo e especiarias asiáticas, escravos africanos e açúcar brasileiro nos parece decisiva para que as geometrias do Império Português fossem possíveis, cabendo ao capital mercantil lusitano os ganhos de arbitragem entre os mercados, que financiaram a expansão colonial.

Além disso, o Brasil, assim como a Ásia e a África, contribuiu de forma decisiva ao fornecer produtos comercializáveis e monopolizáveis. ${ }^{50} \mathrm{Na}$ América Portuguesa,

\footnotetext{
${ }^{46}$ MENZ, M., notas.

${ }^{47}$ COSTA, Leonor Freire, LAINS, P., MIRANDA, S. M., História Económica de Portugal... Op. cit., p. 128

${ }^{48}$ CARRARA, Ângelo Alves, Receitas e despesas da Real Fazenda no Brasil: século XVII... Op. cit.. p. 102 et seq.

${ }^{49}$ NOVAIS, Fernando A., Portugal e Brasil na Crise do Antigo Sistema Colonial... Op. cit., p. 96.

${ }^{50}$ PEDREIRA, Jorge Miguel, Custos e Tendências Financeiras do Império Português, 1415 - 1822, IN BETHENCOURT, Francisco e CURTO, Diogo Ramada (orgs.) A expansão marítima portuguesa... Op. cit., p. 70.
} 
primeiramente foi o Pau Brasil, utilizado para tingimento de tecidos, e que teve seu comércio monopolizado pela Coroa, garantindo alguns rendimentos interessantes. Lançando mão dos arrendamentos, podemos dizer que o Contrato do Pau Brasil foi o primeiro que a Coroa tomou como importante. Porém, o contrato que se mostraria mais lucrativo seria o do tabaco. Com mercado garantido, este arrendamento seguiria nas mãos de particulares até finais do século XVIII. As receitas do tabaco, ao menos desde a segunda metade do século XVII, já figuravam entre as receitas mais importantes para a fazenda régia e continuariam neste patamar mesmo durante a mineração. ${ }^{51}$

$\mathrm{Na}$ passagem para o século XVIII, o Império teve seu papel financeiro reescalonado. As descobertas de ouro no Brasil e a expansão do comércio do açúcar e tabaco exigiriam novas formas de fiscalização para que o contrabando e o descaminho fiscal, em grande escala com a mineração, fossem minimizados. Os confiscos feitos junto aos contrabandistas, nos primeiros anos de mineração, teriam sido bem maiores do que com a tributação, quando o quinto arrecadado chegou a aproximadamente $1 / 3$ das confiscações. Este cenário se mostrou fundamental para o estabelecimento das casas de fundição e das "derramas",52

$\mathrm{O}$ advento da mineração expandiu as receitas fiscais e potencializou a existência de sobras nas provedorias coloniais. ${ }^{53}$ A Coroa se interessava pelos impostos produzidos no Ultramar, e por isso promoveu uma "centralização" das arrematações dos contratos. Esta ação pode ser observada nos números de arrematações que passaram a figurar nas atividades do Conselho Ultramarino. ${ }^{54} \mathrm{O}$ número de contratos é mais que duplicado do primeiro para o segundo livro de registro ${ }^{55}$, tanto na "criação" de novos

\footnotetext{
${ }^{51}$ LOPES, Gustavo Acioli, Negócio da Costa da Mina e comércio atlântico: tabaco, açúcar, ouro e tráfico de escravos, Pernambuco (1654-1760), tese de doutorado, Universidade de São Paulo, 2008, p. 125.

${ }^{52}$ Cotas fixas de pagamentos em ouro que as localidades deveriam providenciar, em alguns momentos independente da extração. Este sistema será modificado diversas vezes ao longo de todo período minerador. Cf. PEDREIRA, Jorge Miguel, Custos e tendências financeiras... Op. cit., p. 70-1. No caso dos confiscos, 16,5 kgs versus 43,8 kgs. PINTO, Virgílio Noya, O Ouro Brasileiro e o Comércio Anglo Português: Uma Contribuição aos Estudos da Economia Atlântica no Século XVIII (2 $2^{\mathrm{a}}$ ed.), São Paulo, 1979, p. 60.

${ }^{53}$ CARRARA, Ângelo Alves, Receitas e Despesas da Real Fazenda no Brasil: século XVIII... Op. cit., p. 39, 94-6.

${ }^{54}$ MENZ, M. Capitalismo e Colonização, Relatório Projeto Temático FAPESP, 2012, p. 85; PAIVA, A., Banco de Dados dos Contratos do Conselho Ultramarino, Relatório Bolsa Treinamento Técnico 3 (TT3), 2012.

${ }^{55}$ O primeiro Livro de Registro dos Contratos, 1671 - 1731, conta com 100 contratos, ao passo que o segundo, 1731 - 1753, conta com 260 contratos. Tomando como ponto inicial o primeiro contrato, em 1671 (Contrato e estanque da Fábrica do Anil do Maranhão - Arquivo Histórico Ultramarino, Administração Central, Conselho Ultramarino, Contratos Reais, Códice 296, fls. 119b - 121a) até 1719 (Contrato do Sal deste Reino que vai para o Brasil - Arquivo Histórico Ultramarino, Administração
} 
contratos, quanto na "subida" destes: antes arrematados nas provedorias locais, passaram à arrematação neste órgão central, sediado em Lisboa, proporcionando o acesso a estes papéis aos maiores homens de negócio estabelecidos na metrópole.

Ou seja, a crescente importância da América Portuguesa para a Coroa no século XVIII tinha reflexo na esfera fazendária. A arrematação dos contratos, agora cativa ao espaço metropolitano, mostra como a euforia econômica do ultramar abriu interesses também para que a coleta de impostos, atividade antes reservada ao espaço colonial, chamasse a atenção dos agentes metropolitanos, na maioria mercadores, que encontraram nesse cenário mais uma fonte de rentabilização para seus capitais. Como bem observou Bruno Aidar, "o governo imperial a partir de Lisboa já não era polissinodal, mas vinculado a apenas um conselho," sediado em Lisboa e não mais nas colônias. ${ }^{56}$

Talvez seja possível falar de um questionamento ao paradigma administrativo nesta ação de centralizar os contratos, tirando da alçada das provedorias locais a sua administração. No mesmo viés estaria a criação da "Secretaria de Estado de Negócios de Marinha e Domínios Ultramarinos”, em 1736, acelerando a tomada de decisões e o despacho na administração do Estado. ${ }^{57}$ Parte deste movimento de afirmação do poder régio vem em resposta ao crescimento das rendas oriundas dos distritos mineradores. Estes proporcionaram a expansão de algumas atividades relacionadas à extração mineral em outras localidades, como por exemplo, as entradas de escravos pelos portos do Rio de Janeiro, que eram destinados ao trabalho minerador ${ }^{58}$. O que tencionamos deixar claro é que a mineração foi fundamental para a organização do sistema fiscal colonial brasileiro, pois demandou maior organização do poder central para coibir os descaminhos e consolidou o Brasil entre os maiores rendimentos do Império.

Sendo assim, uma parte da historiografia ressalta a importância da constituição de um excedente comercial que era transferido à metrópole, graças às políticas protecionistas como a prática do monopólio. Desse modo, a Coroa garantia uma balança

Central, Conselho Ultramarino, Contratos Reais, Códice 296, fls. 337b - 343) temos dezesseis contratos, enquanto que apenas nos cinco primeiros anos da década de 1720 encontramos vinte e dois contratos.

${ }^{56}$ COSTA, Bruno Aidar, A Vereda dos Tratos: Fiscalidade e poder regional na capitania de São Paulo, 1723 -1808, tese de doutorado, Universidade de São Paulo, 2012, p. 138.

${ }^{57}$ SUBTIL, José, Governo e Administração... Op. cit., p. 162.

58 Não obstante, para o caso de São Paulo, "parece correto destacar que a ascensão do Conselho Ultramarino sobre a arrematação dos contratos dos domínios foi lenta até 1722 e errática entre 1723 e 1735, estando completamente assegurada apenas no período de 1736 a 1761." COSTA, Bruno Aidar, A Vereda dos Tratos... Op. cit., p. 141. 
comercial favorável ao Reino. ${ }^{59}$ Contudo, no século XVIII, houve uma mudança na geração de receitas: do excedente oriundo das relações comerciais e do monopólio, configurou-se um sistema baseado na fiscalidade que garantia grandes receitas para Portugal. ${ }^{60}$ A forma de recolha de tributos baseada na arrematação de contratos, foi assim, parte fundamental da organização administrativa e econômica do Império português. A arrematação previa um monopólio, que tanto poderia se basear em produtos oriundos do estanco quanto de relações territoriais.

Ainda que possamos colocar em dúvida este procedimento, já que muitos dos contratos acabavam renovados com os mesmos cessionários, a dinâmica das arrematações seguiu esta lógica: primordialmente eram postas a lanço nas provedorias locais, em seguida no Conselho Ultramarino e, por fim, nas Juntas e no Erário Régio, que a partir de sua criação passou a fiscalizar e regular as arrematações. Não obstante, em diversos casos ocorria o que se chama de "retalhamento" dos contratos, prática que acabava por onerar relativamente mais os pequenos produtores do que os grandes, já que "a camada mais elevada (...), comprando uma porção do ramo do contrato, ficava no mínimo isenta do imposto, e no máximo realizava algum lucro."61 Ou seja, os maiores produtores, em vez de simplesmente pagar os tributos relativos às suas produções, podiam operar também no mercado dos arrendamentos, comprando uma parte do contrato, que podia em muitos casos ser muito pequena, e com isso cobrar de si mesmos, opção não disponível aos pequenos lavradores e que estavam obrigados ao pagamento a outrem em cima do que produziam.

Atendo-nos às características puramente econômicas dos contratos, devemos levar em consideração, a relação risco x lucratividade. Consta nos contratos, ainda que em alguns casos possam ter sido revistas, cláusulas expondo que em toda forma de "quebra" o valor do contrato deve ser honrado como foi acordado no momento de sua arrematação. Da mesma forma, os lucros "normais" e em alguns casos mesmo os extraordinários, deveriam ser encarados como fruto da "boa administração do contrato". Além disso, outros benefícios eram garantidos ao contratador em cláusulas específicas,

\footnotetext{
${ }^{59}$ ARRUDA, José Jobson, A Produção Econômica, IN SILVA, Maria Beatriz Nizza da, Nova História da Expansão Portuguesa; O Império Luso-Brasileiro (1750 - 1822), vol. VIII, 1992, p. 90.

${ }^{60}$ CARRARA, Ângelo Alves, Receitas e despesas da Real Fazenda no Brasil: século XVIII... Op. cit., p. 20.

61 GALLO, Alberto. Colóquio Internacional Economia e Colonização na Dimensão do Império Português, São Paulo, 30 de Setembro-3 de Outubro 2008 / Mesa 1. Fiscalidade e Poder Imperial, 30 de Setembro de 2008. p. 5.
} 
como por exemplo, outro monopólio adjunto ao contrato ${ }^{62}$, o privilégio do porte de armas, e a não necessidade de se prestar o serviço militar. ${ }^{63}$

A ascensão de Sebastião José de Carvalho e Melo, futuro Marquês do Pombal, inaugura um período de grandes inovações administrativas. O Conselho de Fazenda se firma na matéria das finanças como exclusiva instância judicial, reforçando sua competência jurisdicional. Contudo, com a criação do Erário Régio em 1761, perdeu todas as suas prerrogativas do campo financeiro. Na esteira das reformas empreendidas pela administração Josefina, o Erário congregou todas as atividades de fiscalização e controle do sistema financeiro, bem como do fluxo das arrecadações, fluxo de impostos e destinação dos fundos da Real Fazenda. ${ }^{64}$

A ideia da centralização das contas em apenas um órgão veio no sentido de diminuir as possibilidades de prevaricação e abusos vindos de tesoureiros e almoxarifes, que por suas ações podiam levar o erário a prejuízos. As práticas que eram vigentes até então, pelo grande número de pessoas envolvidas, tornava todo o sistema lento e sujeito a condições favoráveis ao descaminho, tornando-se assim ineficiente. Assim sendo, a reforma como disciplinadora das finanças públicas, agia como medida de modernização do aparelho do Estado. Ao mesmo tempo em que a implantação destas medidas auxiliava Portugal a aproximar-se das nações mais desenvolvidas, foi importante para o fortalecimento do absolutismo e "constituiu pedra fundamental na consolidação do monopólio fiscal como expressão da afirmação do poder."

Pombal, o presidente deste novo órgão, acumularia também o cargo de intendente, seguido imediatamente por um tesoureiro-mor, responsável pela TesourariaGeral. Existiam ainda quatro contadorias, cada qual com seus contadores gerais, tendo como função "arrecadar os depósitos feitos pelos corregedores, provedores, juízes, almoxarifes, tesoureiros e outros recebedores e contratadores das rendas reais". 66 Os territórios imperiais foram divididos nessas quatro grandes contadorias, sendo a primeira responsável pela Corte e Província de Estremadura; a segunda para o restante do Reino e ilhas dos Açores e Madeira; a terceira para África Ocidental, Maranhão e Bahia e a quarta para o Rio de Janeiro, África Oriental e Ásia.

\footnotetext{
${ }^{62}$ Como o monopólio do marfim, adjunto ao contrato do Reino de Angola.

${ }^{63}$ ARAUJO, Luiz Antônio Silva, Fiadores, procuradores e testas de ferro... Op. cit., p. 78-9

${ }^{64}$ SUBTIL, José, Governo e Administração...Op. cit., p. 154-5.

65 TOMAZ, Fernando, As Finanças do Estado Pombalino: 1762 - 1776, IN Estudos e Ensaios em Homenagem a Vitorino Magalhães Godinho, Lisboa: Livraria Sá da Costa Editora, 1988, p. 355-6.

${ }^{66}$ SUBTIL, José, Governo e Administração... Op. cit., p. 155.
} 
Uma das inovações inseridas pelo Erário Régio foi a implementação das partidas dobradas. Este método consiste em uma nova forma de contabilização das dívidas ativas e passivas nos livros contábeis e tornava obrigatória a descrição destes movimentos financeiros em "duas colunas": de "deve" e "haver". A utilização deste novo método uniformizava as informações que eram prestadas e permitia o maior controle das rendas, já que os livros de cada contadoria deveriam ser conferidos pelo tesoureiro-mor. Essas medidas, centralizadoras das receitas e despesas, tinham por objetivo também o de concentrar o poder destas matérias, "retirando aos tesoureiros e almoxarifes o direito de fazer pagamentos e aos Tribunais da Fazenda de arrecadar as receitas., 67

Ao período que se segue após a morte de D. José I, não se observa grandes modificações na estrutura que organizava as finanças portuguesas. O que se observa após o consulado pombalino é a mudança pontual de algumas cobranças. Nesse sentido, podemos afirmar que a administração Josefina, assim, assentou as bases de todo o sistema fazendário que perduraria até meados do século $\mathrm{XIX}^{68}$. Com efeito, diversas críticas ao caráter "patrimonialista" que alguns grandes contratos adquirem, tem maior reverberação neste período. A ideia das arrematações prorrogadas ao contratador vigente $^{69}$ iria de encontro aos pressupostos da própria arrematação, assim como contrárias às regras que deveriam ser observadas no processo da contratação. ${ }^{70}$ Esta prática é bastante significativa ao longo da década de 1790, principalmente após decreto de D. Maria I, na qual os contratos poderiam ser prorrogados sem ter de ir à hasta pública. ${ }^{71}$ A proximidade à Coroa que o negócio dos grandes contratos proporcionava e a aceitação da participação de particulares em operações financeiras - empréstimos, por

\footnotetext{
${ }^{67}$ MOREIRA, Alzira Teixeira Leite, Inventário do Fundo Geral do Erário Régio, Arquivo do Tribunal de Contas, Lisboa: 1977, p. X

${ }^{68}$ Arquivo Nacional do Tribunal de Contas de Portugal (http://www.tcontas.pt/pt/apresenta/historia/tc1761-1832.shtm acessado em 13/05/2015).

${ }^{69}$ Em favor da centralização, preferia ocupar os lugares chave com suas "criaturas”, “(...) recorrendo ao argumento que sempre acompanha a apologia dos contratadores: é preferível dar os contratos a capitalistas de reconhecida solidez do que a aventureiros que muito provavelmente não vão cumprir as condições convencionadas. (...) O contrato é demasiado poderoso para poder ser deixado na posse de elementos cuja fidelidade não esteja assegurada." COSTA, Fernando Dores. Crise Financeira, Dívida Pública e Capitalistas. 1796 - 1807. Lisboa, dissertação de mestrado apresentada na Faculdade de Ciências Sociais e Humanas da Universidade Nova de Lisboa. 1992, p. 214.

${ }^{70}$ OLIVAL, Fernanda, COSTA, Fernando Dores, Elites económicas IN LAINS, Pedro e SILVA, Álvaro Ferreira da (orgs.) História Económica de Portugal, 1700 - 2000, vol. 1 O século XVIII, Lisboa: ICS. Imprensa de Ciências Sociais, $3^{\circ}$ ed., 2005, p. 330.

${ }^{71}$ COSTA, Fernando Dores. Crise Financeira... Op. cit., p. 212.
} 
exemplo - pressupôs a inversão da polaridade da operação, já que passou a caracterizar um "serviço" por parte dos particulares.", 72

Até agora percorremos alguns caminhos para indicar como se organizou a administração das rendas imperiais portuguesas em torno da fiscalidade. Uma questão em relação ao sistema físcal do Império seria se este dava na realidade algum lucro. Se para o século XVII, "as despesas determinaram as receitas" "73, o mesmo pode não se repetir para o XVIII. Quando as potências europeias consolidaram suas posições coloniais, por volta da segunda metade do século XVII, estas apresentavam basicamente um mesmo regime de exploração. Entretanto, quando observadas em conjunto, podemos separar de um lado o capital mercantil europeu em expansão, e do outro as economias coloniais, culminando na essência do sistema de exploração de um pelo outro. ${ }^{74}$

Portanto, podemos destacar como fundamentais para a consolidação deste "sistema" dois aspectos: os monopólios e o pacto colonial. O arrendamento de contratos, baseados neste binômio, aparece como uma das tecnologias do poder que fez com que Portugal chegasse ao propósito da colonização ultramarina: a transferência de rendas para a metrópole, ao mesmo tempo em que não "fosse ameaçado o profundo vínculo político com a camada dominante de seus moradores." ${ }^{\text {"75 }}$ Enquanto Portugal caminhou cada vez mais para aumento da carga e da relação dos particulares na execução dos impostos, no caminho contrário a Inglaterra baseava sua política fiscal em cobranças indiretas e administração estatal da arrecadação. ${ }^{76}$ Desse modo, no caso

\footnotetext{
${ }^{72}$ Em finais do século XVIII, por parte de grandes contratadores, como Jacinto Fernandes Bandeira e Ignácio Pedro Quintela, ligados a diversos contratos, dentre eles o do Tabaco, foi captado um empréstimo, em 1794, para pagamento de dividendos da coroa. Em contrapartida, tiveram seu monopólio sobre o tabaco prorrogado por mais seis anos. Anos depois, já na primeira década do XIX, os mesmos contratadores figuraram na lista dos avalizadores de um novo empréstimo. Este serviço poderia ser "cobrado" em outra situação, pois "(...) num sistema de trocas, um serviço é a produção de um desequilíbrio em favor daquele que o faz."Cf. COSTA, Fernando Jorge Dores. Crise Financeira... Op. cit., p. 207-8.

${ }^{73}$ CARRARA, Ângelo Alves, Receitas e despesas da Real Fazenda no Brasil: século XVII... Op. cit., p. 62, MENZ, M.M., notas de aula (11) e LENK, Wolfgang, Guerra e Pacto Colonial... Op. cit., p. 323.

${ }^{74}$ "O exclusivo metropolitano no comércio colonial consiste em suma na reserva do mercado das colônias para a metrópole, isto é, para a burguesia comercial metropolitana. Este o mecanismo fundamental, gerador de lucros excedentes, lucros coloniais; através dele, a economia central metropolitana incorporava o sobreproduto das economias coloniais ancilares" NOVAIS, Fernando. Portugal e Brasil na crise do Antigo Sistema Colonial... Op. cit., pp. 88-89.

${ }^{75}$ LENK, Wolfgang, Guerra e Pacto Colonial... Op. cit., p. 369.

${ }^{76}$ COSTA, Leonor Freire, LAINS, P., MIRANDA, S. M., História Económica de Portugal... Op. cit., p. 207
} 
português, a arrematação dos contratos podia ser encarada de duas formas: um caminho para o enriquecimento dos vassalos, ao mesmo tempo em que tomava os contratadores como braços que ampliavam o controle e a hegemonia do Estado. ${ }^{77}$

A extração aurífera alterou as relações que Portugal mantinha com as outras nações e faz com que sua balança comercial tomasse contornos não experimentados até então. O Brasil, no século XVIII responsável por mais de $50 \%$ da produção mundial do metal, ampliou a demanda dos produtos oriundos da metrópole, com inclusão de objetos de uso doméstico e vestuário ${ }^{78}$. Assim, a atividade mineradora pujante e a recuperação do açúcar geravam remessas de valores para Lisboa ${ }^{79}$, enquanto o comércio com o Oriente entrava em um período de estagnação; se observarmos o desenho do Império em seu conjunto, podemos perceber a diminuição relativa do Oriente e um aumento, influenciado pela mineração e outros produtos coloniais, do Brasil. ${ }^{80}$

A reorganização dos sistemas de arrecadação, tocada após o terremoto de 1755, foi fundamental para aumentar a eficácia da Fazenda. Mas não só: a abolição da distinção entre "cristão-novo" e "cristão-velho" e a nobilitação da atividade mercantil do grosso trato, no consulado pombalino, deve ser encarada como importantes. Com essa alteração de status, se durante o período do Antigo Regime estes homens de negócio eram mal vistos e não conseguiam proximidade com a Corte, em finais do século XVIII este grupo beneficiou-se da proximidade do centro do Estado Imperial. Em alguns casos os grandes negociantes, ou seja, a elite econômica metropolitana, em toma ares de aristocracia. A partir da segunda metade do Setecentos, com o estatuto do negociante, a concessão de honrarias que sempre fora negada a eles, passou a ser concedida com frequência, inclusive o hábito da Ordem de Cristo. ${ }^{81}$

No tempo largo, a tríade exclusivo-monopólio-privilégio se sobrepõem e se alternam como os principais mecanismos de extração do excedente colonial. Entretanto, as regras do jogo foram sendo alteradas durante todo o período, frutos da óbvia historicidade de um sistema. Seja como for, é possível falar de uma conjuntura fiscal? Algum favorecimento dos mercadores residentes teria ocorrido, em detrimento do capital mercantil metropolitano e da fiscalidade real? Cremos que não é isto que os

\footnotetext{
${ }_{77}^{7}$ ARAUJO, Luiz Antônio Silva, Fiadores, procuradores e testas de ferro... Op. cit., p. 78.

${ }^{78}$ COSTA, Leonor Freire, LAINS, P., MIRANDA, S. M., História Económica de Portugal... Op. cit., p. 246-7

${ }^{79}$ CARRARA, Ângelo Alves, Receitas e despesas da Real Fazenda no Brasil: século XVIII... Op. cit., Anexos

${ }^{80}$ PEDREIRA, Jorge Miguel, Custos e Tendências Financeiras... Op. cit., p. 73

${ }^{81}$ OLIVAL, Fernanda, COSTA, Fernando Dores, Elites económicas... Op. cit., pp. 338-42.
} 
estudos sobre o período Josefino e mariano indicam. ${ }^{82}$ Em todo o caso, a análise das conjunturas fiscais a ser feita no próximo capítulo poderá lançar mais luzes sobre este questionamento. $^{83}$

\footnotetext{
${ }^{82}$ ALDEN, Dauril. O periodo final do Brasil Colônia, 1750-1808. IN BETHELL, Leslie (org.). História da América Latina: América Latina Colonial. Tradução Mary Amazonas Leite de Barros e Magda Lopes. São Paulo: EDUSP, 2004; ARRUDA, José Jobson de Andrade. O sentido da colônia. Revisitando a crise do antigo sistema colonial no Brasil (1780-1830). IN TENGARRINHA, José (org.). História de Portugal. $2^{a}$ ed. São Paulo: Editora Unesp, 2001; CARRARA, Ângelo Alves. Minas e Currais... Op. cit.; COSTA, Fernando Jorge Dores. Crise Financeira... Op. cit.; MAXWELL, Kenneth. A devassa da devassa... Op. cit.; NOVAIS, Fernando. Portugal e Brasil na Crise do Antigo Sistema Colonial... Op. cit.; Idem. Aproximaç̧̃es. Estudos de história e historiografia. São Paulo: Cosac Naify, 2005.

${ }^{83}$ LENK, Wolfgang, Guerra e Pacto Colonial... Op. cit., p. 370.
} 


\section{Capítulo II - Demanda, Capital e Produção Colonial}

"Como desdobramento da expansão comercial, a colonização insere-se no processo de superação das barreiras que se antepuseram, no fim da Idade Média, ao desenvolvimento da economia mercantil, e ao fortalecimento das camadas urbanas e burguesas."1

Neste capítulo, pretendemos discutir as conjunturas por meio de séries relativas à produção. O objetivo é analisar o que poderíamos chamar de "indicadores gerais" da economia colonial: as curvas nos preços do açúcar, preços do tabaco, produção do ouro, e importação de escravos. Já no próximo capítulo focaremos na análise dos contratos propriamente ditos, procurando verificar se existe uma correlação entre os "indicadores gerais" de produção e os valores lançados pelos contratadores.

\section{"A Civilização do Açúcar"2}

Gênero que perpassa todo o período colonial, a comparação dos preços do açúcar em diferentes praças pode oferecer importante indicativo para percebermos os movimentos da economia. Produto mais representativo nas rendas coloniais até a mineração, o açúcar permaneceu como um dos mais importantes gêneros na pauta de exportações brasileiras até o final do século XVIII. Mesmo com o processo de diversificação agrícola, o produto foi caracterizado na faixa de média lucratividade por Jobson Arruda. ${ }^{3}$

A organização da cultura do açúcar, dada em latifúndios com altos patamares de produção, alavancava os níveis de renda dos setores dominantes, do ponto de vista econômico, da colônia. Além disso, foi a principal responsável na movimentação de

\footnotetext{
${ }^{1}$ NOVAIS, Fernando Antônio. Aproximações... Op. cit., p. 46.

2 Tomamos emprestado o título do trabalho da professora Vera Lucia Amaral Ferlini, publicado em 1984 sob a série "Tudo é História", vol. 88, da Editora Brasiliense.

3 A empresa açucareira chegou a representar uma lucratividade na casa dos $40 \%$, se considerarmos o açúcar branco, perdendo apenas para o negócio dos couros $(53,8 \%)$ e algodão $(64,5 \%)$, porém, estes com produção muito menor e mais localizada no final do século XVIII. No caso dos couros, ao menos desde meados do século XVIII já se observam remessas não insignificantes na região amazônica. "A saber, café $(84,68 \%)$, arroz $(101,29 \%)$ e produtos com presença secular no trânsito comercial: cacau $(99,7 \%)$ e tabaco (103,74\%)." ARRUDA, José Jóbson de Andrade, Superlucros: a prova empírica do exclusivo colonial. IN Topoi (Rio J.),v. 15, n. 29, jul./dez. 2014 . p. 711.
} 
atividades auxiliares, como a produção de farinhas ${ }^{4}$ por exemplo, além de estimular a vinda da mão de obra escrava africana para as plantações brasileiras. A historiografia recente tem demonstrado que a produção de alimentos nos próprios engenhos era insuficiente para o sustento dos planteis, e os produtos para subsistência eram comprados no mercado, gerando demanda para outras atividades.

Paulatinamente, as terras pouco aptas para a produção de açúcar eram ocupadas para a produção de alimentos: roças de mandioca e outros produtos agrícolas nas zonas mais próximas do litoral, e de gado bovino no sertão. Também o fornecimento de escravos para os engenhos gerava outras atividades econômicas, como a construção naval na Bahia, além de alimentos que eram demandados para as tripulações e para os cativos. Em todas essas ocupações, utilizava-se amplamente a mão de obra gerando uma alta demanda por trabalhadores escravizados oriundos da costa da África ${ }^{5}$.

O açúcar era o principal elemento de ascensão social e de formação das elites nas cidades de Salvador e Recife, que assumiam os cargos militares e administrativos na colônia. Ou seja, o açúcar - muito além de uma mera atividade econômica sobredeterminava as relações sociais e políticas na colônia. Era um elemento agregador dos aspectos econômicos, políticos e sociais. Além de garantir lucros e ascensão social, era uma atividade que tinha um efeito multiplicador sobre a economia local. O estímulo também era sentido em outras localidades, como nas capitanias do sul $^{6}$, onde "gradativamente, o açúcar foi imprimindo às terras e aos homens uma nova configuração, assentando as bases de um mundo de senhores e escravos que o café se encarregaria de consolidar." ${ }^{\prime 7}$ Em finais do século XVIII, animados pela mudança da capital para o Rio de Janeiro e com o crescimento da população dos escravos libertos, observa-se “(...) o desenvolvimento de uma infraestrutura de estradas melhoradas,

\footnotetext{
${ }^{4}$ A farinha de mandioca era demandada para alimentação em geral e também para o plantel de escravos, em alguns casos servindo até para exportação, como indica PINTO, Virgílio Noya, O ouro brasileiro... Op. cit., p. 188. A carestia de víveres deste tipo foi abordada por MENZ, Maximiliano Mac. Reflexões sobre duas crises econômicas no Império Português (1688-1770) IN Varia História, Programa de PósGraduação em História, Faculdade de Filosofia e Ciências Humanas, Universidade Federal de Minas Gerais - vol. $29 \mathrm{n}^{\circ} 49$ - jan./abr. 2013. pp. $42-44$.

${ }^{5}$ Cf. SCHWARTZ, Stuart B. Escravos, roceiros e rebeldes. Bauru: EDUSC, 2001; BARICKMAN, B. J. Um contraponto baiano: açúcar, fumo, mandioca e escravidão no Recôncavo, 1780-1860. Rio de Janeiro: Civilização Brasileira, 2003; LAPA, José Roberto do Amaral. A Bahia e a Carreira da Índia. São Paulo: Companhia Editora Nacional, 1968.

6 "De certa maneira, podemos afirmar que, no caso do Rio de Janeiro, o tráfico criou o açúcar, incrementando sua dinâmica econômica desde o final do XVII. Cana para aguardente, aguardente para escravos, escravos para cana e para a mineração - a produção açucareira fluminense inseriu-se num esquema bastante próximo da auto-estimulação.” FERLINI, Vera Lucia Amaral. Açúcar e Colonização. São Paulo: Alameda, 2010. p. 201-2.

${ }^{7}$ FERLINI, Vera Lucia Amaral. Açúcar e Colonização... Op. cit., p. 185.
} 
instalações portuárias e cabotagem, que viabilizaram e tornaram lucrativo o abastecimento do mercado carioca." 8

Observemos os preços do açúcar em Lisboa ao longo do século XVIII, de maneira a alcançar um primeiro indicador do movimento geral da economia:

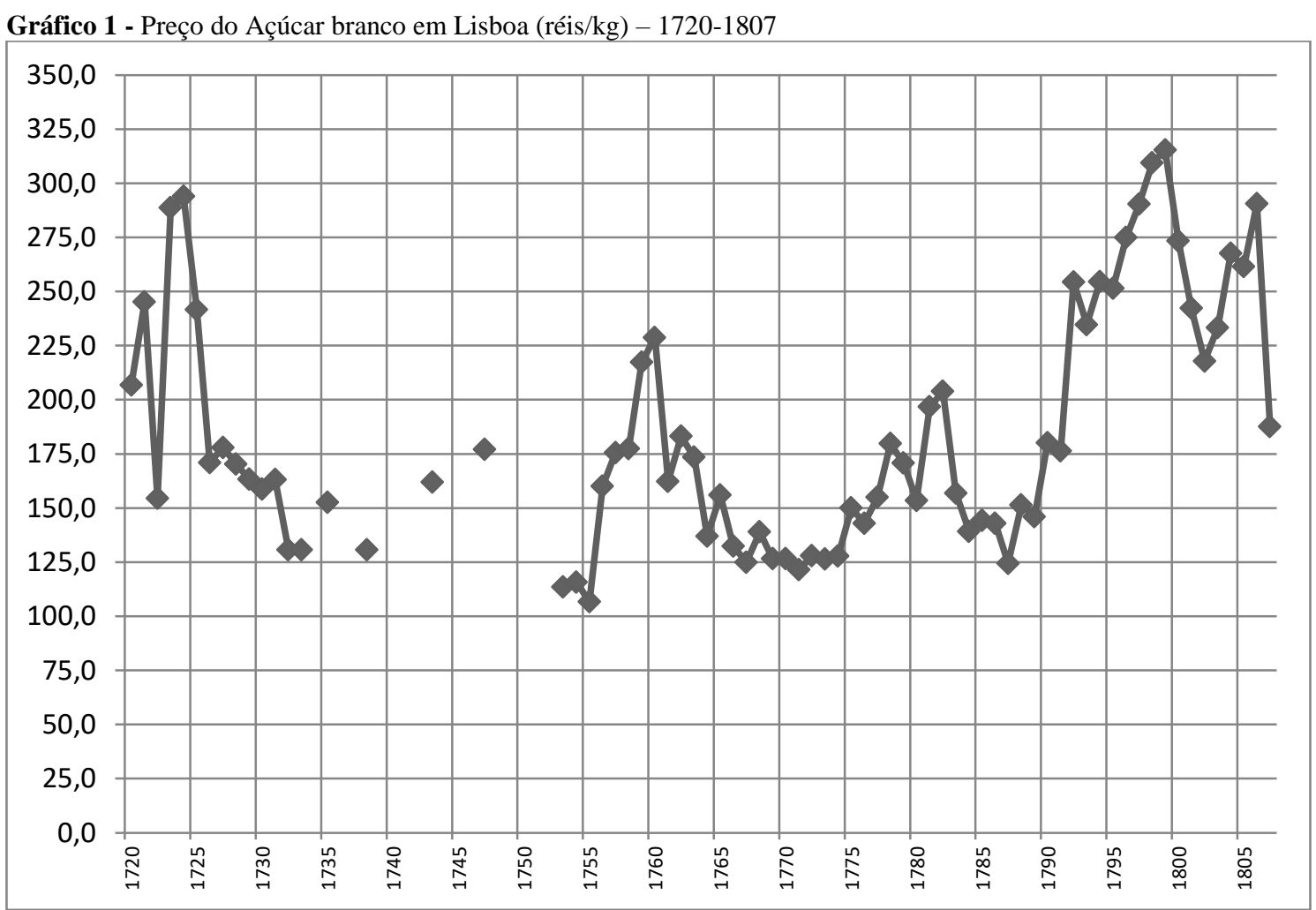

Fonte: LOPES, Rui , Preços e Salários dos Frades Menores, séc. XVII, Liv o 2; MADUREIRA, Nuno Luís (1996), Consumo, preços e salários (1760-1830), Ler História, Lisboa: ISCTE, no 32 (pp. 5-32) Apud Honey and sugar prices in Lisbon, PWR - Prices, Wages and Rents in Portugal, 2013.

Os preços pagos em Lisboa pelo açúcar branco sofrem grande variação ao longo do século XVIII, atingindo seu valor máximo em 1799, valendo 315.3 réis o quilo, e seu ponto mais baixo no ano de 1755, o ano do terremoto, com 106.5 réis o quilograma. Para que possamos analisar de forma mais detida, dividiremos o gráfico em duas partes, tomando como marco divisório a criação do Erário Régio em dezembro de 1761, quebrando a série no ano de 1762. Dada a ligação de nosso trabalho com a fiscalidade e a organização das rendas do Império Português, pensamos ser uma escolha adequada utilizar este marco institucional como divisão:

\footnotetext{
${ }^{8}$ SCHWARTZ, Stuart B. Escravos, roceiros...Op. cit. p. 140.
} 
Gráfico 2 - Preço do Açúcar branco em Lisboa (réis/kg) - 1720-1762

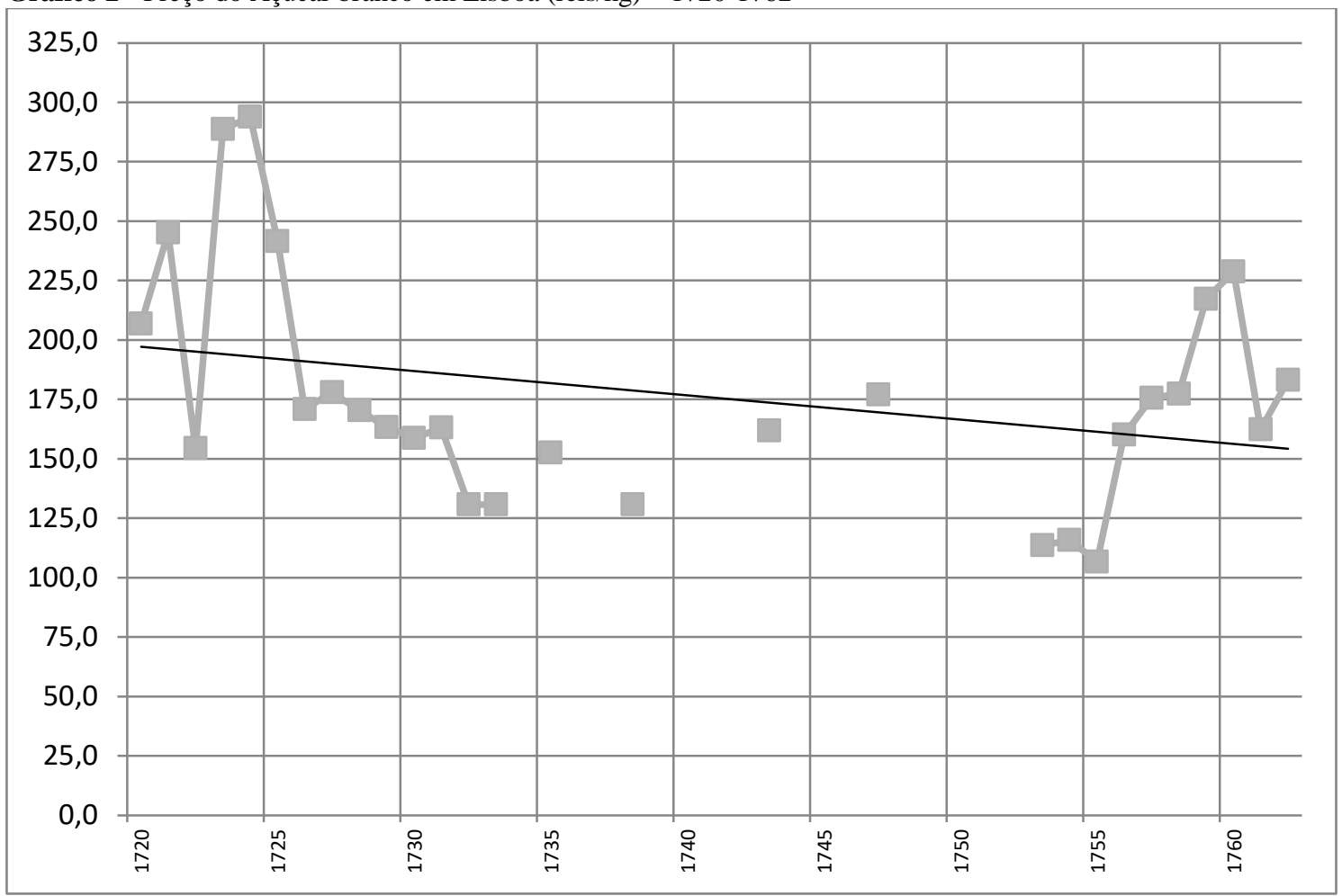

Fonte: LOPES, Rui , Preços e Salários dos Frades Menores, séc. XVII, Liv o 2; MADUREIRA, Nuno Luís (1996), Consumo, preços e salários (1760-1830), Ler História, Lisboa: ISCTE, $\mathrm{n}^{\circ} 32$ (pp. 5-32) Apud Honey and sugar prices in Lisbon, PWR - Prices, Wages and Rents in Portugal, 2013.

Ainda que tenhamos valores acima dos 200 réis por quilograma entre os anos de 1720 e 1725, em grande parte do período analisado os valores estiveram abaixo desse patamar. Houve quinze apontamentos entre 150 réis e 200 réis; seis entre 100 e 150 réis e uma recuperação acima dos 200 réis, após grande queda ocorrida nos anos 1750, quando atingiu seu preço mais baixo. Por mais que haja algumas lacunas nessa parte da série, a tendência entre 1720 e 1762 é de baixa nos preços do açúcar. Analisemos o mesmo período a partir dos dados compilados por Dauril Alden e ajustados por Stuart Schwartz, agora para a Bahia. 
Gráfico 3 - Preço do Açúcar branco na Bahia (réis/kg) - 1720-1762

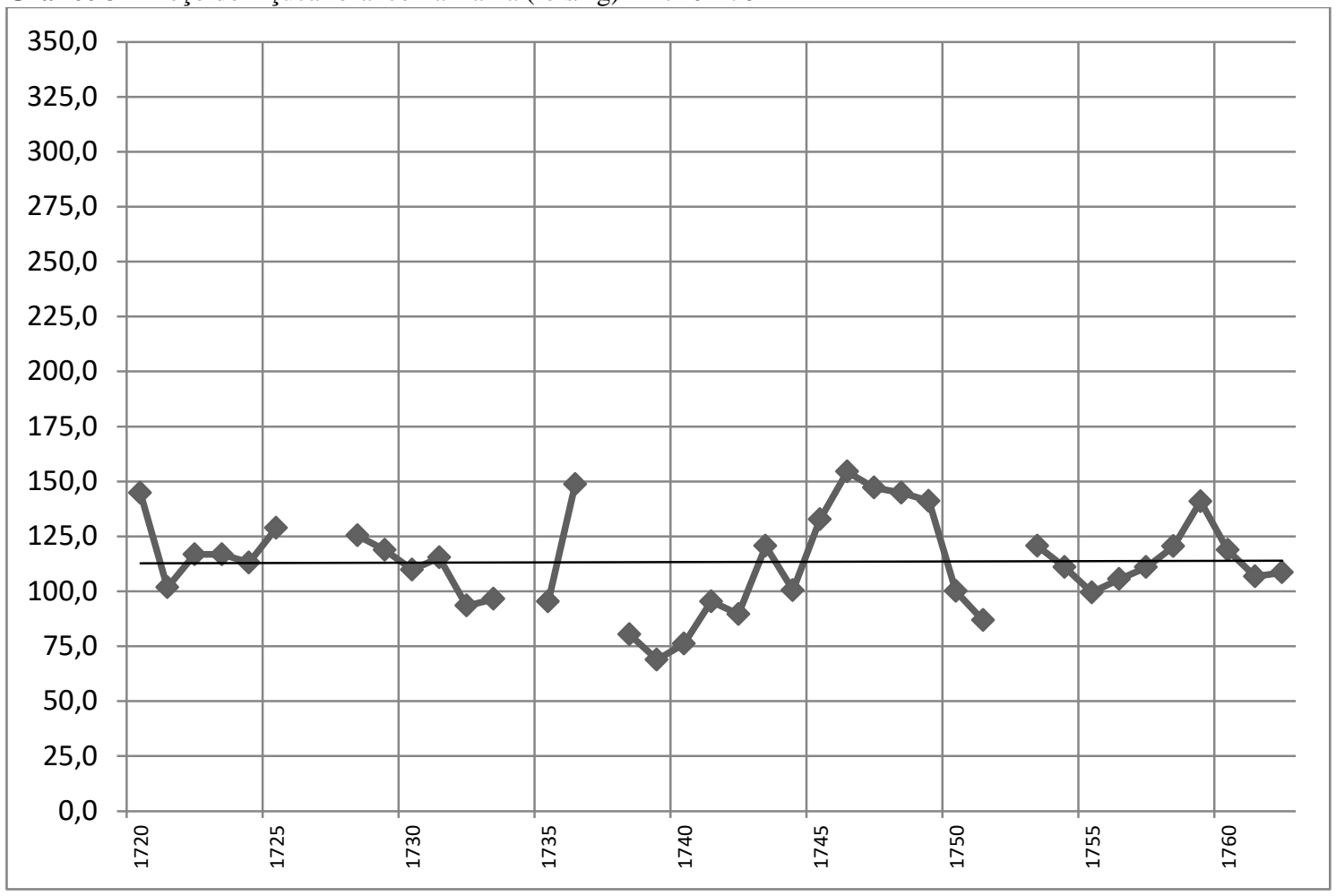

Fonte: ALDEN, Dauril. Price Movements in Brazil Before, During and After the Gold Boom, IN Essays on the Price Histories of 18th Century Latin America pp. 340-341, series for "white sugar"; SCHWARTZ, Stuart B. Sugar Plantations in the Formation of Brazilian Society: Bahia 1550-1835. Cambridge: Cambridge, 1985. Apud Brazil - 1550-1779 GPIHG - Global Price and Income History Group.

Notadamente, os preços do açúcar branco aferidos na Bahia diferem relativamente daqueles que encontramos em Lisboa, fruto das margens de custo e lucro entre uma e outra cidade, apontando uma tendência à estagnação. Ainda que possamos identificar uma leve recuperação de 1740 até 1746 , seguido por nova queda até 1751. A seguir analisemos o Gráfico 4, que conta com estes dados, porém transformados em índices, tendo como marco o ano de $1762^{9}$ :

\footnotetext{
${ }^{9}$ Para esta escolha seguimos a divisão que escolhemos para facilitar nossas análises, levando em conta a data de criação do Erário Régio. A opção de transformação dos valores em índices vem no sentido de podermos apreender de forma mais proveitosa o comportamento das curvas geradas pela variação destes valores, independentemente de seus valores nominais aferidos.
} 
Gráfico 4 - Preço do Açúcar branco Bahia x Lisboa - 1720-1762 (índice 1762 = 100)

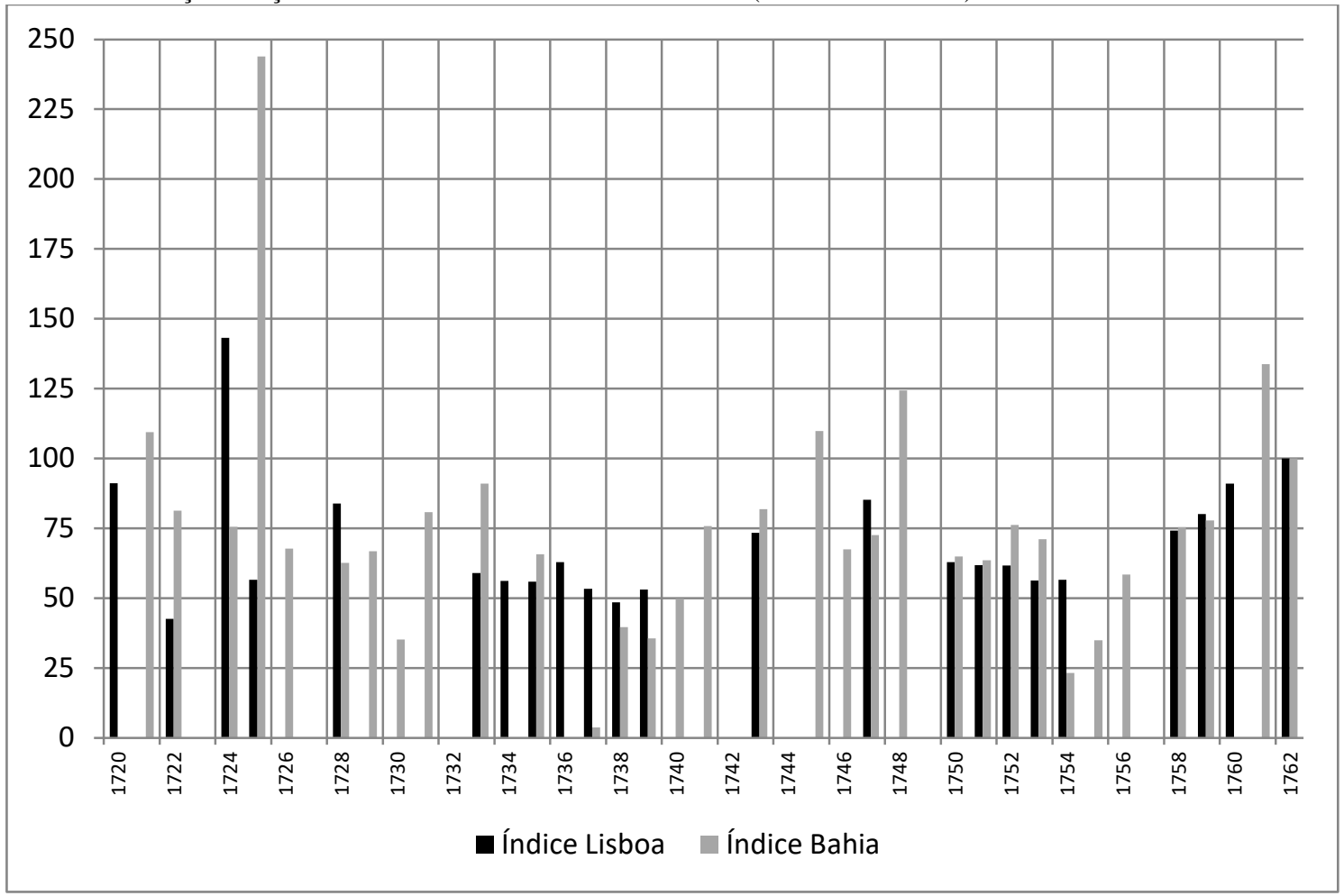

Fonte: LOPES, Rui , Preços e Salários dos Frades Menores, séc. XVII, Liv ${ }^{\circ}$; MADUREIRA, Nuno Luís (1996), Consumo, preços e salários (1760-1830), Ler História, Lisboa: ISCTE, $\mathrm{n}^{\circ} 32$ (pp. 5-32) Apud Honey and sugar prices in Lisbon, PWR - Prices, Wages and Rents in Portugal, 2013; ALDEN, Dauril. Price Movements in Brazil Before, During and After the Gold Boom, IN Essays on the Price Histories of 18th Century Latin America pp. 340-341, series for "white sugar"; SCHWARTZ, Stuart B. Sugar Plantations in the Formation of Brazilian Society: Bahia 1550-1835. Cambridge: Cambridge, 1985. Apud Brazil - 1550-1779 GPIHG - Global Price and Income History Group.

Optamos pela apresentação destes dados em índices para evidenciar uma característica bastante interessante: podemos notar uma confluência nas variações dos valores na praça colonial e na metrópole. Claro que em alguns anos, especificamente 1722, 1724 e 1725 e 1763 existe uma diferença na flutuação, mas que podemos classificar como algo pontual, já que em todos os anos restantes a oscilação dos preços tende a acompanhar seu correspondente da outra ponta do Atlântico com alguma similaridade.

Já que não dispomos de dados para a Bahia a partir do ano de 1768, utilizaremos então para comparação os preços do gênero aferidos no Rio de Janeiro a partir do ano de 1763 (Gráfico 5). Nosso propósito é o de complementar nossa análise da flutuação dos preços do açúcar, para verificar se há de fato uma conjuntura comum entre os valores encontrados na colônia e na metrópole: 
Gráfico 5 - Preço do Açúcar branco no Rio de Janeiro (réis/kg) - 1763-1807

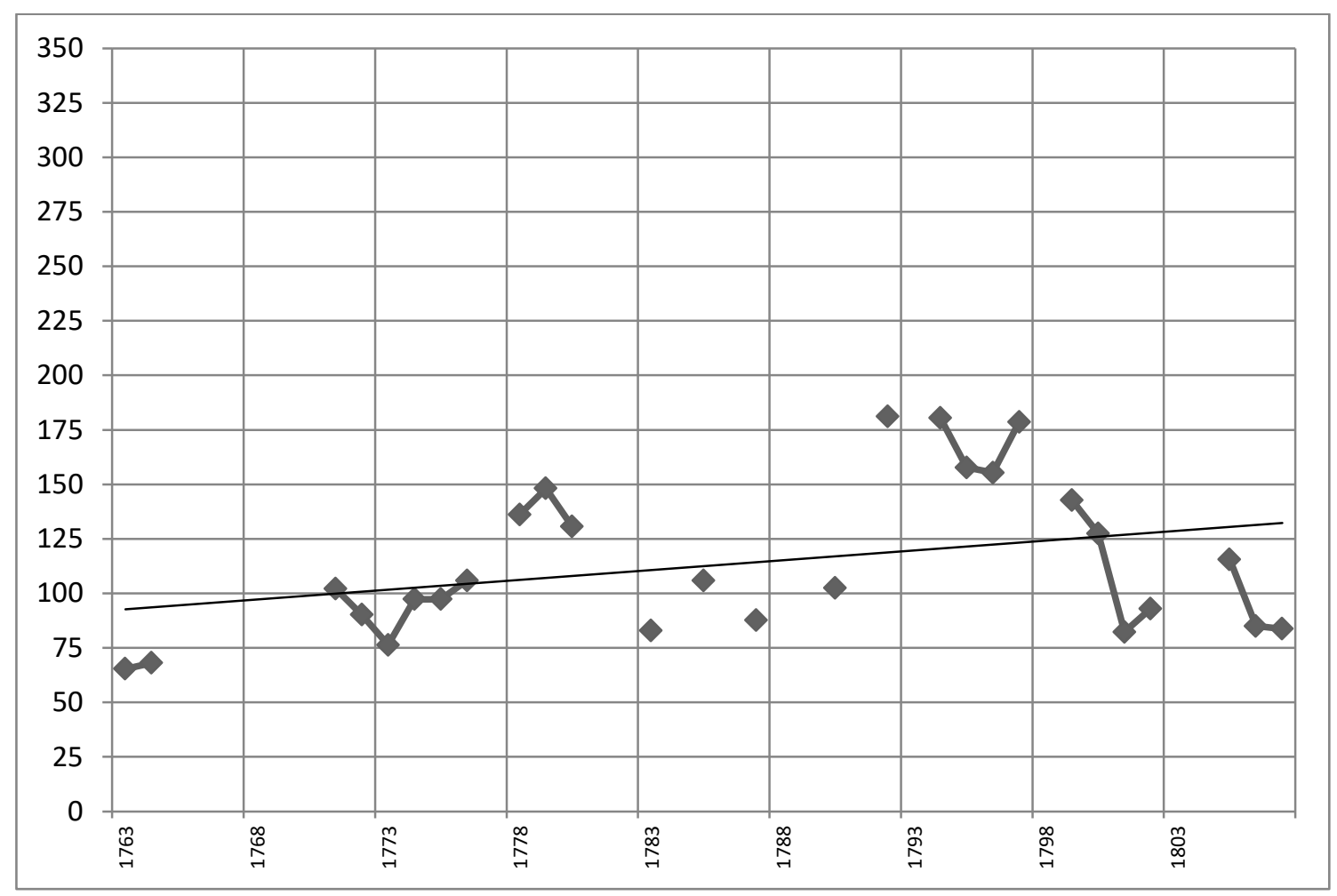

Fonte: JOHNSON Jr., Harold. A preliminary inquiry into money, prices, and wages in Rio de Janeiro, 1763-1823. In: ALDEN, Dauril (ed.). Colonial roots of modern Brazil. Berkeley: University of California Press, 1973, pp. 274-6.

Apesar de algumas lacunas na fonte, o primeiro movimento que podemos perceber uma variação negativa em meados da década de 1770, seguida de recuperação que se anunciava a partir de 1773 , que se sustenta até os 148 réis por quilograma, no ano de 1779. Como demonstrado no gráfico 6, após um período de estagnação nos preços de Lisboa, uma recuperação destes é sentida a partir do ano de 1774 . Na virada para a década seguinte, ambas as series apontam para uma leve queda. Após algumas variações nos poucos lançamentos que possuímos de 1780 a 1794, o movimento que pode ser mais bem apreendido está nos 4 lançamentos seguintes, que mostram variações que são sucedidas por uma grande queda nos preços, até 1801, quando retorna aos valores na casa dos 80 réis, movimento de queda bastante semelhante ao que foi aferido para a metrópole, no período 1799-1802 quando se desvaloriza em quase 100 réis no preço. 


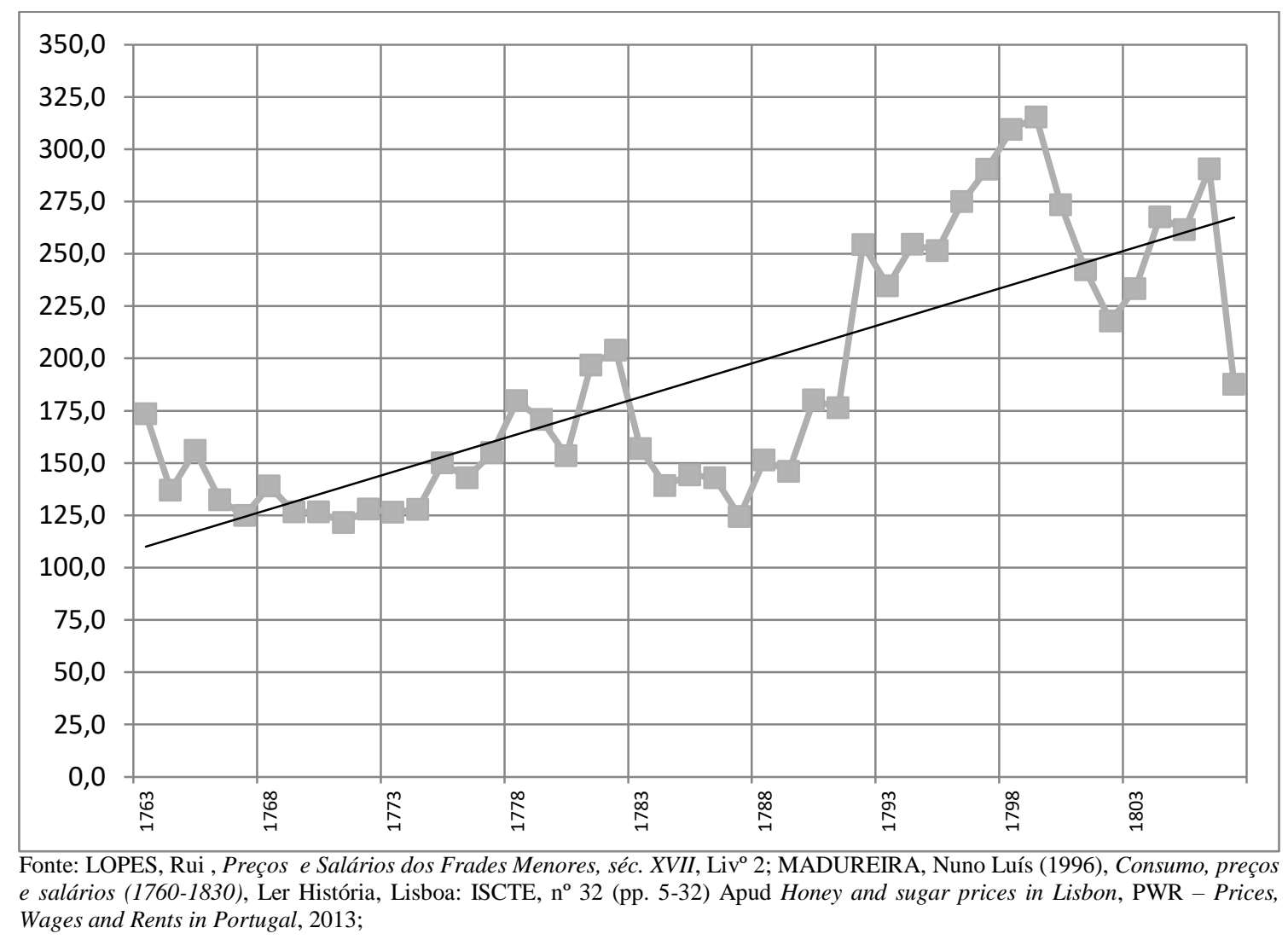

No gráfico 6 podemos observar a clara tendência de alta nos preços em Lisboa. Alguns movimentos distintos podemos depreender da série: 1763-1782, estagnação com viés de alta; 1782-1787, breve período de queda; 1787-1799, valorização constante, partindo de 124 réis e chegando em 315.3 réis, ou seja, uma valorização de $254 \%$.

O que a comparação da metrópole com caso o Rio de Janeiro pode nos mostrar (Gráfico 7), mais do que movimentos completamente coincidentes, são os movimentos "chave" análogos de queda/valorização dessas duas praças. A integração que a economia açucareira fluminense passa a experimentar nesta segunda metade do Setecentos, pode passar a ser percebida nessas variações dos preços. Antes ligada apenas ao abastecimento das Minas e ao serviço do transporte do ouro, a economia do Rio de Janeiro, impulsionada por estas atividades se relacionará de forma mais direta ao mercado Atlântico e, desta forma, ao tráfico de escravos, conforme abordaremos ao longo do capítulo. 
Gráfico 7 - Preço do Açúcar branco Rio de Janeiro x Lisboa - 1763-1807 (índice $1763=100)^{10}$

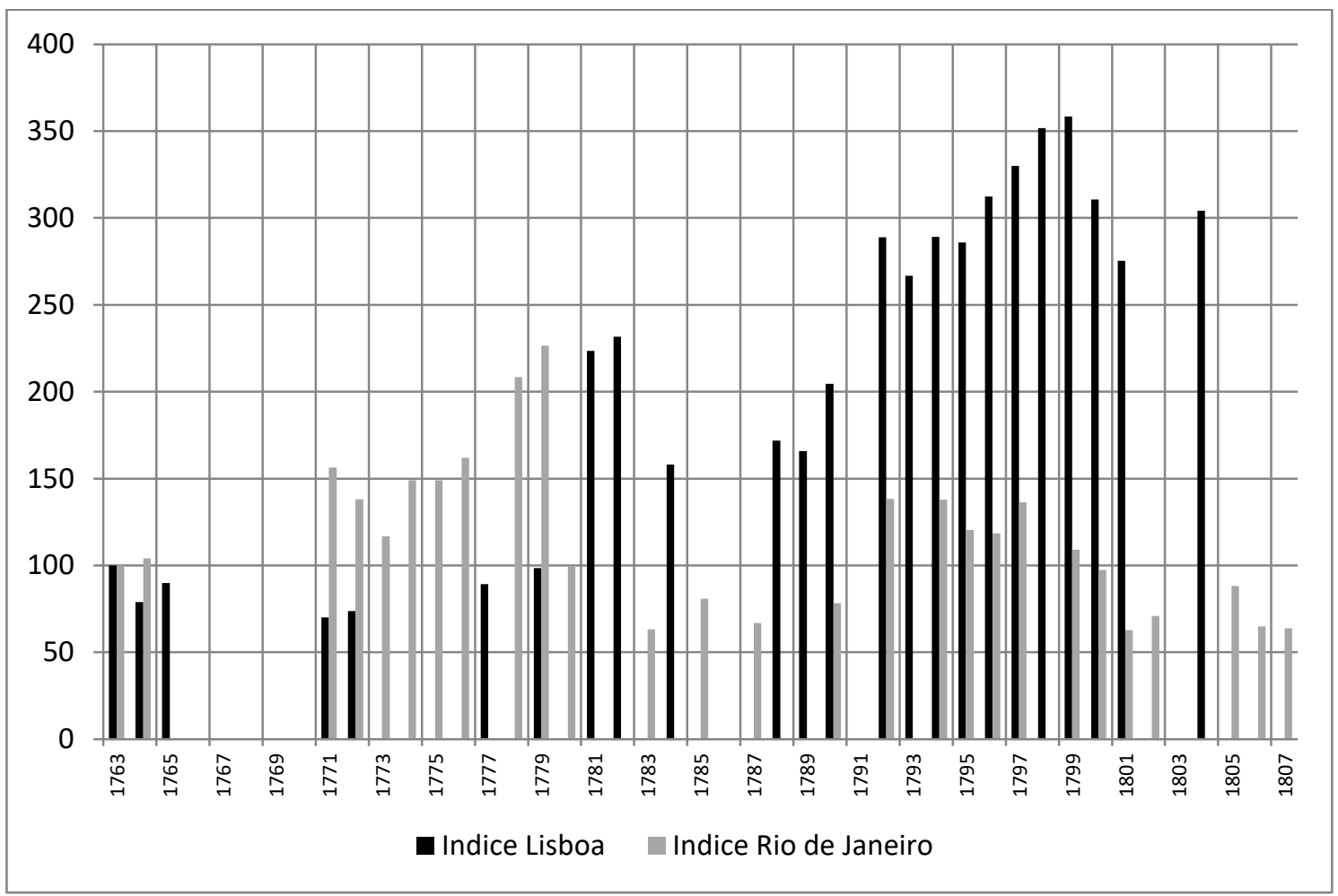

Fonte: JOHNSON Jr., Harold. A preliminary inquiry into money, prices, and wages in Rio de Janeiro, 1763-1823. In: ALDEN, Dauril (ed.). Colonial roots of modern Brazil. Berkeley: University of California Press, 1973, pp. 274-6; LOPES, Rui , Preços $e$ Salários dos Frades Menores, sec XVII, Liv 2; MADUREIRA, Nuno Luís (1996), Consumo, preços e salários (1760-1830), Ler História, Lisboa: ISCTE, no 32 (pp. 5-32) Apud Honey and sugar prices in Lisbon, PWR - Prices, Wages and Rents in Portugal, 2013;

Tendo em vista o caráter exportador da produção açucareira e sua interconexão com os mercados mundiais, a seguir apresentamos um gráfico com os preços gerais do açúcar nas principais praças europeias, Lisboa, Londres e Amsterdã para que possamos observar se há uma estrutura de preços mundial do gênero. Considerando a diferença nas tendências entre a primeira e a segunda metade do século e a organização de nossas fontes ${ }^{11}$, apresentamos os dados em três partes, começando com uma visão geral (Gráfico 8 para todo o período, Gráfico 9 de 1720 a 1762 e Gráfico 10, de 1763 a 1807).

\footnotetext{
${ }^{10}$ Apenas neste gráfico utilizamos como marco do índice o ano de 1763, pois não possuímos dados relativos ao Rio de Janeiro para o ano de 1762.

${ }^{11}$ Para a primeira parte, até 1762, utilizamos para os preços de Lisboa os dados de Dauril Alden, ajustados por Stuart Schwartz e convertidos para o equivalente em prata pelo GPIHG. Para o segundo, utilizamos os dados disponibilizados pelo $P W R$.
} 
Gráfico 8 - Preço do Açúcar em Londres, Lisboa e Amsterdã (gramas de prata/kg) 1720-1807

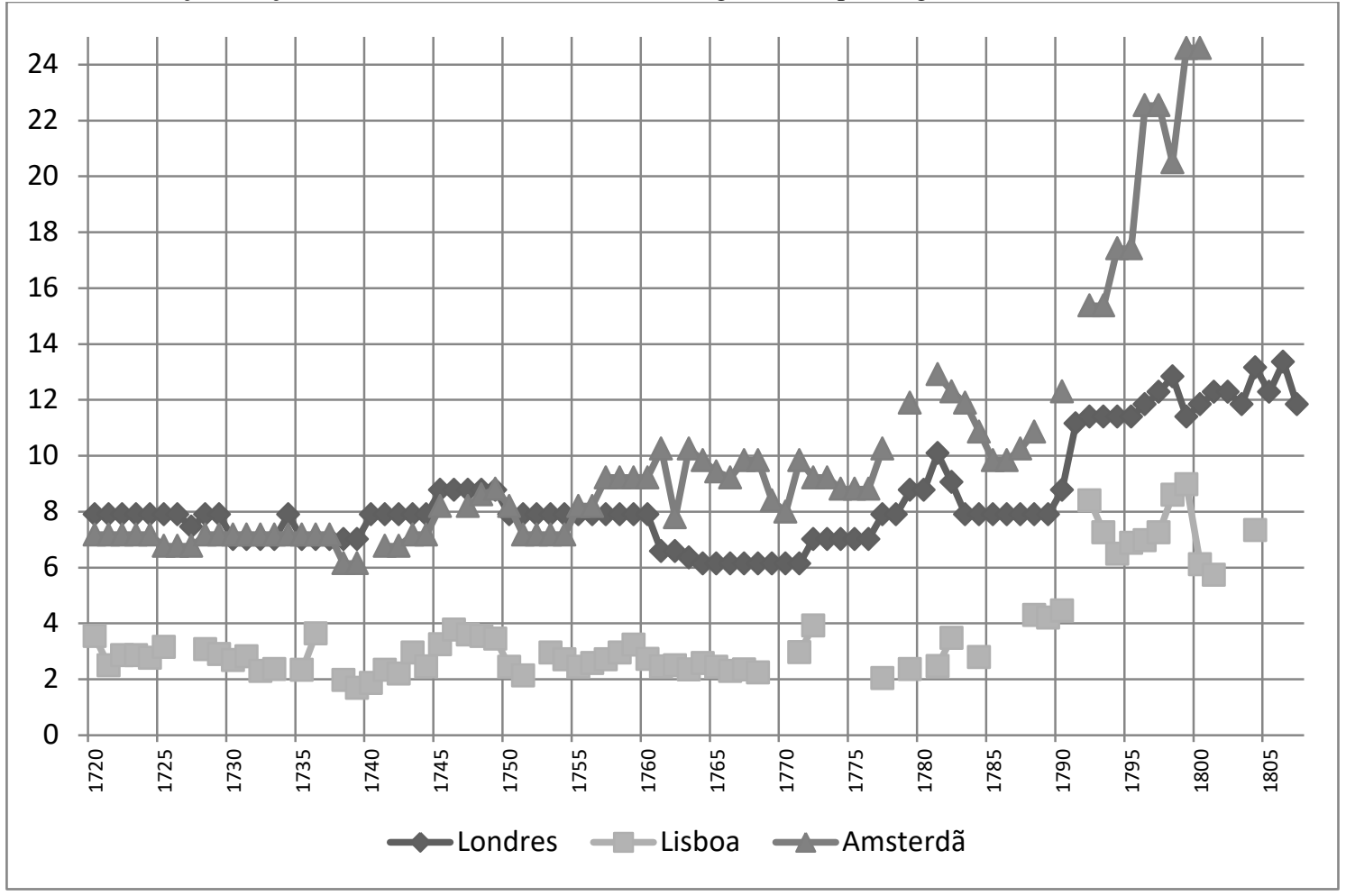

Fonte: LOPES, Rui , Preços e Salários dos Frades Menores, séc. XVII, Liv ${ }^{\circ}$; MADUREIRA, Nuno Luís, Consumo, preços e salários (1760-1830), Ler História, Lisboa: ISCTE, $\mathrm{n}^{\circ} 32$ (pp. 5-32), 1996 Apud Honey and sugar prices in Lisbon, PWR - Prices, Wages and Rents in Portugal, 2013; ALLEN, Robert C., Enclosure and the Yeoman, Oxford: Clarendon Press, 1992; Posthumus, N.W., Inquiry into the history of prices in Holland, vol.2, Leiden: Brill, 1964, pp. 272-83. Apud ALLEN, Robert C., Prices and Wages in Amsterdam \& Holland, 1500-1914, International Institute of Social History/ GPIHG - Global Price and Income History Group.

No Gráfico 8 podemos observar que mesmo que não haja uma profunda correspondência entre os preços aferidos nas diferentes praças, percebemos certa similaridade nos movimentos das curvas entre as três localidades: período de queda a partir de 1738, seguido de recuperação até 1746, bem como a alta observada no período de 1755 a 1759 e a queda a partir da década de 1760, com tendência positiva após o ano de 1787. Vejamos agora como se comportam as curvas para o período entre 1720 e 1762: 
Gráfico 9 - Preço do Açúcar em Londres, Lisboa e Amsterdã (gramas de prata/kg) 1720-1762

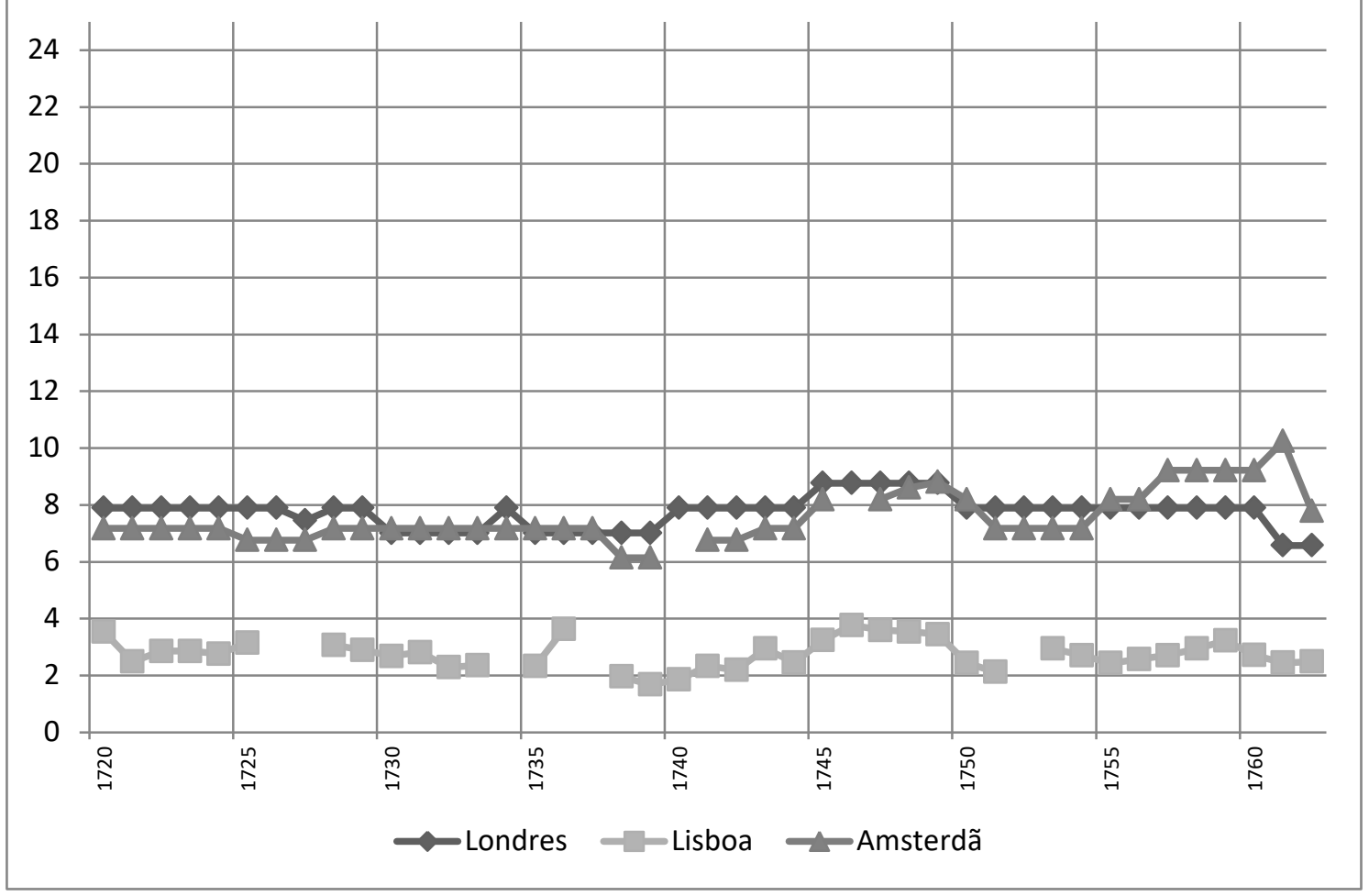

Fonte: LOPES, Rui , Preços e Salários dos Frades Menores, séc. XVII, Livo 2; MADUREIRA, Nuno Luís, Consumo, preços e salários (1760-1830), Ler História, Lisboa: ISCTE, $\mathrm{n}^{\circ} 32$ (pp. 5-32), 1996 Apud Honey and sugar prices in Lisbon, PWR - Prices, Wages and Rents in Portugal, 2013; ALLEN, Robert C., Enclosure and the Yeoman, Oxford: Clarendon Press, 1992; POSTHUMUS, N.W., Inquiry into the history of prices in Holland, vol.2, Leiden: Brill, 1964, pp. 272-83. Apud ALLEN, Robert C., Prices and Wages in Amsterdam \& Holland, 1500-1914, International Institute of Social History/ GPIHG - Global Price and Income History Group.

A tendência do gráfico 9 é de estabilidade e correspondência, uma vez que não existiam grandes variações entre os mercados, na primeira metade do século XVIII. Além disso, constata-se que Amsterdã e Londres competem em pé de igualdade nos preços do açúcar. Quando se observa os preços para esse primeiro recorte, notamos uma tendência de pouca flutuação dos mesmos para Londres e Amsterdã e Lisboa. Vejamos agora o que ocorre no segundo recorte de análise, começando a partir do ano de 1763: 
Gráfico 10 - Preço do Açúcar em Londres, Lisboa e Amsterdã (gramas de prata/kg) 1763-1807

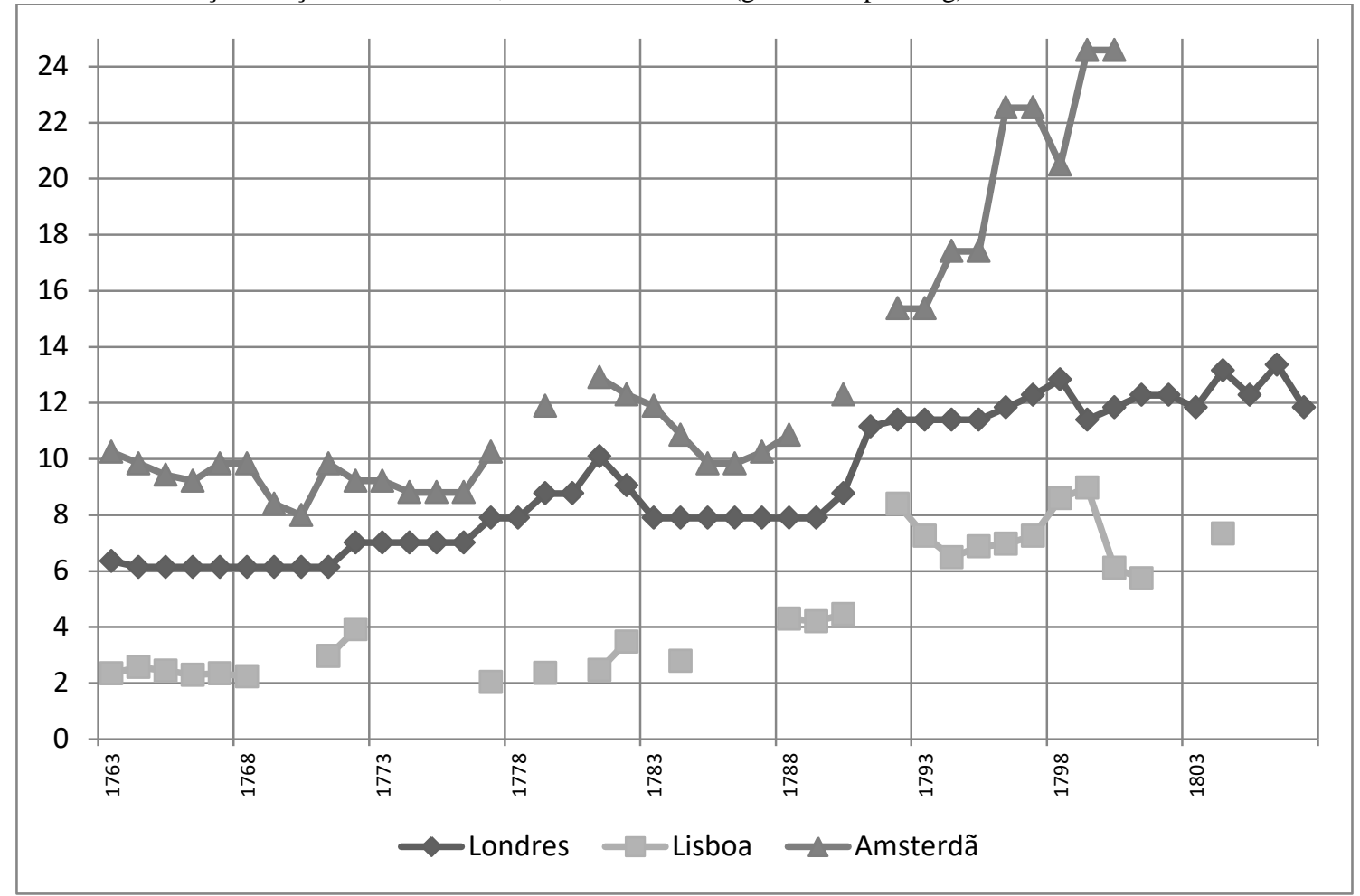

Fonte: LOPES, Rui , Preços e Salários dos Frades Menores, séc. XVII, Liv ${ }^{\circ}$; MADUREIRA, Nuno Luís (1996), Consumo, preços e salários (1760-1830), Ler História, Lisboa: ISCTE, $\mathrm{n}^{\circ} 32$ (pp. 5-32) Apud Honey and sugar prices in Lisbon, PWR - Prices, Wages and Rents in Portugal, 2013; ALLEN, Robert C., Enclosure and the Yeoman, Oxford: Clarendon Press, 1992; POSTHUMUS, N.W., Inquiry into the history of prices in Holland, vol.2, Leiden: Brill, 1964, pp. 272-83. Apud ALLEN, Robert C., Prices and Wages in Amsterdam \& Holland, 1500-1914, International Institute of Social History/ GPIHG - Global Price and Income History Group.

Notamos uma diminuição da similaridade nas curvas dos preços em relação a Lisboa e observamos um salto nos preços pagos em Amsterdã ao final da série, a partir de 1792 (Gráfico 10). Esta descolagem do mercado de Amsterdã pode ser causada pelas guerras associadas à Revolução Francesa, como por exemplo, o processo da Revolução Haitiana. Mas não só. Também nessa época o açúcar das colônias britânicas era destinado exclusivamente para a Inglaterra. ${ }^{12}$ Isso explica a diferença dos preços da Inglaterra para com os de Amsterdã. De vez que suficientemente abastecido o mercado interno, os mercadores britânicos não precisavam competir em mercados estrangeiros.

Se a similaridade com os dados relativos a Lisboa diminui - ainda que este acompanhamento não seja possível devido às lacunas na fonte - o mesmo não pode se dizer em relação aos dados aferidos nas outras duas praças analisadas, Londres e Amsterdã. De 1763 até 1790 as curvas se acompanham ${ }^{13}$; a partir da década de 1790 os

\footnotetext{
${ }^{12}$ PEDREIRA, Jorge. Estrutura Industrial e mercado colonial. Portugal e Brasil (1780-1830). Lisboa: Difel, 1994, p. 53.

${ }^{13}$ Tendo a diferença entre si nos valores aferidos de 1,5 a 2,9 gramas de prata por quilograma de açúcar, como mostra o gráfico 8 .
} 
preços em Amsterdã disparam e podemos observar certa similaridade com o movimento de Lisboa, que demonstra certa recuperação a partir de 1795. Sinteticamente, as curvas gerais são: 1720-1738, estagnação com viés de queda; 1739-1749, ascendente; 17501771, estagnação com viés de queda; 1772-1781, ascendente; 1782-1807, estagnação seguida de alta.

Em resumo, não é possível afirmar que os preços no Brasil pudessem ser regulados pelos próprios produtores, configurando um sellers market. ${ }^{14}$ Ao contrário. Parece que a ideia mais clara, a partir dos dados, é de que os preços do açúcar seriam determinados externamente, pelos mercados situados principalmente em Londres e Amsterdã. Mesmo que em alguns períodos não comprem açúcar produzido no Brasil, controlam os preços do gênero, pressionando os negociantes e influenciando diretamente as flutuações do mercado mundial do açúcar.

De certa forma, esta ideia, já apontada por Celso Furtado, pode ser comprovada ao analisarmos estas curvas de preços e a ligação destas com os ganhos reais da produção do açúcar, que se dava substancialmente nestas praças até a primeira metade do século XVIII. Assim, uma parcela dos rendimentos que eram atribuídos aos senhores de engenho estariam localizadas nas mãos dos não residentes, ou seja, fora da colônia. ${ }^{15}$ Esta hipótese, aliás, é demonstrada pela maior estabilidade dos preços em Lisboa que se verifica no gráfico 4 .

Sobretudo, o que os últimos três gráficos (8, 9 e 10) nos dizem é algo muito evidente. Os preços eram hierarquizados. Os maiores preços eram aqueles do noroeste europeu, seguidos pelos de Lisboa e por último, o das colônias. A determinação dos preços e sua inter-relação se encontram nessa evidencia simples, e não tanto nas oscilações das curvas, sempre passiveis de imprecisão mas, como demonstramos, elas possuem ritmos semelhantes, conclusão importante para a análise conjuntural que propomos fazer.

Nossa análise se focou então nas alterações de cunho mais duradouro e naqueles momentos de maior vulto nas valorizações/quedas, e que se acompanham nas diferentes praças estudadas. A partir dos dados que dispomos, conseguimos estabelecer em um primeiro período algumas relações de integração da Bahia neste jogo mundial das

\footnotetext{
${ }^{14}$ Menz aponta esta característica para o mercado dos grãos produzidos no Rio Grande do Sul e vendidos no Rio de Janeiro. Dada a falta de oferta deste gênero e a carestia de alimentos na capital, o mercado passaria então a ser controlado pelos produtores, caso inverso ao do açúcar em mais de um aspecto. MENZ, Maximiliano M. Entre Impérios, Op. Cit., p. 166.

${ }^{15}$ FURTADO, Celso, Formação econômica do Brasil... Op. cit., p. 82.
} 
determinações dos preços, o que também foi feito na segunda metade, desta vez com o Rio de Janeiro. A percepção desta hierarquização dos preços nos parece clara ao passo que estas grandes variações expressadas no contexto dominante europeu, Londres e Amsterdã, se sente nos preços de Lisboa, que repassa esta pressão aos mercados da América Portuguesa, que ao longo do século XVIII integra novas regiões ao comércio de exportação, não apenas no ramo da plantação da cana e fabrico do açúcar, mas também nas atividades de apoio desta.

\section{O vil metal}

Ao lado do açúcar, a mineração foi fator importante para a economia colonial durante o setecentos. Os valores aferidos com a sua extração fizeram com que o metal assumisse posição de destaque no contexto do século XVIII. Mesmo se levarmos em conta o pequeno tempo que durou seu boom exportador (aproximadamente de 17201750), as riquezas proporcionadas e as transformações na economia colonial foram imensas. A articulação de economias proporcionada pela mineração ${ }^{16}$ nos coloca em face de algumas características especiais desta atividade. $\mathrm{O}$ fato de o ouro funcionar como moeda, fez com que a economia colonial pudesse criar meios de ser polo de atração/demanda de mão de obra e ganhasse maior pujança em termos de mercado interno. A produção mineral sustentava e proporcionava a reprodução escravista na mineração. $^{17}$

É exatamente nesta dependência da circulação de uma moeda produzida na própria colônia, e não originária de uma demanda externa, que reside a especificidade da economia de Minas: a determinação última da atividade (e não economia) mineradora era absolutamente interna. Seu tempo de duração era determinado pela soma dos tempos de duração do conjunto das empresas. Isso quer dizer que o setor minerador não experimentou nenhuma dependência de oscilações de preços ou de demanda externa por seus produtos - ouro e pedras preciosas. ${ }^{18}$

\footnotetext{
${ }^{16}$ CARRARA, Ângelo. Minas e currais... Op. cit., p. 17-18.

${ }^{17}$ Ibidem, p. 60.

${ }^{18}$ Idem.
} 
A economia mineradora funcionava a partir de diferenciadas formas de extração: desde a pequena lavra até a produção em larga escala, utilizando mão de obra escrava. Assim, as lógicas - e os tempos - da atividade mineradora proporcionavam variadas ações decorrentes - desde a produção de alimentos até a reprodução da escravidão todas elas geradas a partir do caráter multiplicador da mineração, como bem frisou Ângelo Carrara ${ }^{19}$.

Assim como observamos na empresa açucareira, as atividades influenciadas pela mineração no contexto mais local das Minas - pecuária, agricultura etc. - são ligadas pelo vértice da escravidão. Também a criação pecuária, tanto de gado vacum, quanto de muares para transporte, a produção de gêneros alimentícios em condições de comportar o grande fluxo migratório para a capitania e mesmo a disponibilidade de novos ofícios, tornam-se elementos de primeira grandeza para o desenvolvimento da capitania. Mas é a reprodução do modo de produção escravista e sua sustentação que aparecem como o vetor do processo de desenvolvimento econômico aurífero e, porque não, colonial.

Dado seu caráter diferenciado em relação à produção, aonde a sua demanda respondia a um estímulo do rendimento das lavras, a reprodução do escravismo subordinado à produção - se finda em decorrência do esgotamento das minas. O contrário ocorre nas regiões açucareiras, nas quais os estímulos são externos, determinantes da demanda, subordinadores da produção e, por consequência, do sistema escravista em si. Por outro lado, nas franjas do modo de produção escravista, desenvolvem-se formas de produção camponesas que permitem um crescimento autônomo e relativamente independente da demografia colonial ${ }^{20}$.

A integração de regiões antes pouco povoadas ou que não estavam completamente articuladas a um mercado interno de abastecimento, passam a integrar a teia produtiva colonial. O sul da capitania de Minas, o oeste de São Paulo e o extremo Sul, com o Rio Grande de São Pedro, passam a interagir para o abastecimento, animados pela extração aurífera. Com suas produções em contínua integração, mesmo na decadência do ouro, persistiram abastecendo, por sua vez, também o mercado do Rio de Janeiro na segunda metade do século XVIII.

\footnotetext{
${ }^{19}$ Cf. Idem, p. 60-64.

${ }^{20}$ Idem, p. 66-67.
} 
Um bom ponto de partida para nossa análise é verificar, em números gerais, como foi a performance do metal amarelo. Para isso, vejamos como se comporta a curva do rendimento geral do imposto do $1 \%$ do ouro (Gráfico 11).

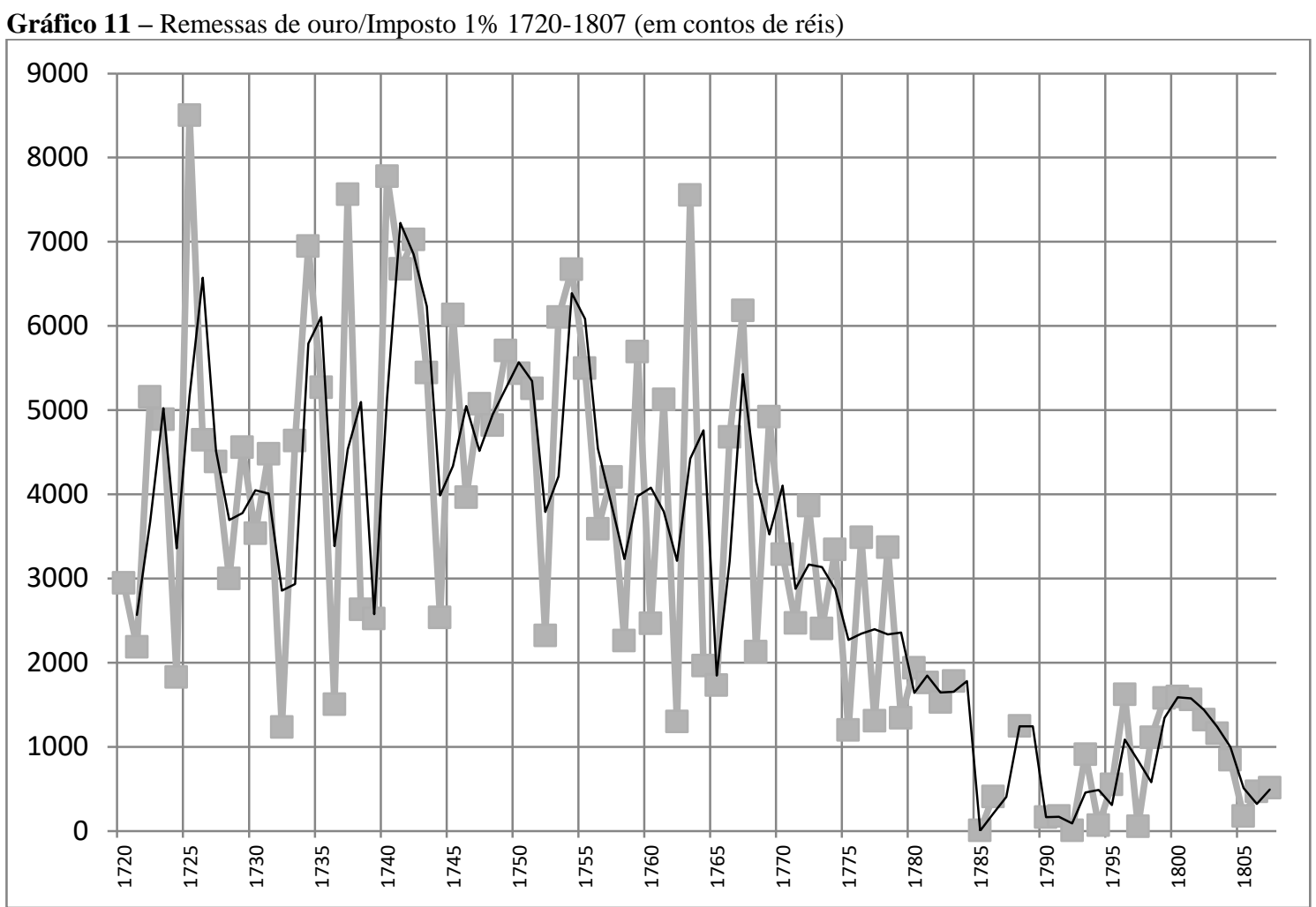

Fonte: Gabinete de História Económica e Social - https://aquila4.iseg.ulisboa.pt/aquila/investigacao/ghes/investigacao/projetoscoordenados-pelo-ghes/o-ouro-do-brasil:-remessas-e-agentes,-1720-1807 (acesso em 11/07/2016). Apud COSTA, Leonor Freire; ROCHA, Maria Manuela; SOUSA, Rita Martins de. O ouro do Brasil, 1700-1807, Lisboa, Imprensa Nacional - Casa da Moeda, 2013.

Ao regime das frotas atribuímos as grandes variações entre os valores anuais. Com o intuito de auxiliar na visualização inserimos uma linha de tendência em médias móveis $^{21}$ e percebemos uma clara tendência descendente, logo após 1767. Porém, a queda já se anunciava desde 1754. Vejamos agora este gráfico transformado em índice, fragmentado em dois ${ }^{22}$, o primeiro dando conta de 1720 a 1762 e o segundo com o restante de nosso período, 1763 a 1807:

\footnotetext{
${ }^{21}$ Período $=2$

${ }^{22}$ Assim como no caso dos gráficos que apresentamos para a comparação do preço do açúcar nas praças europeias.
} 


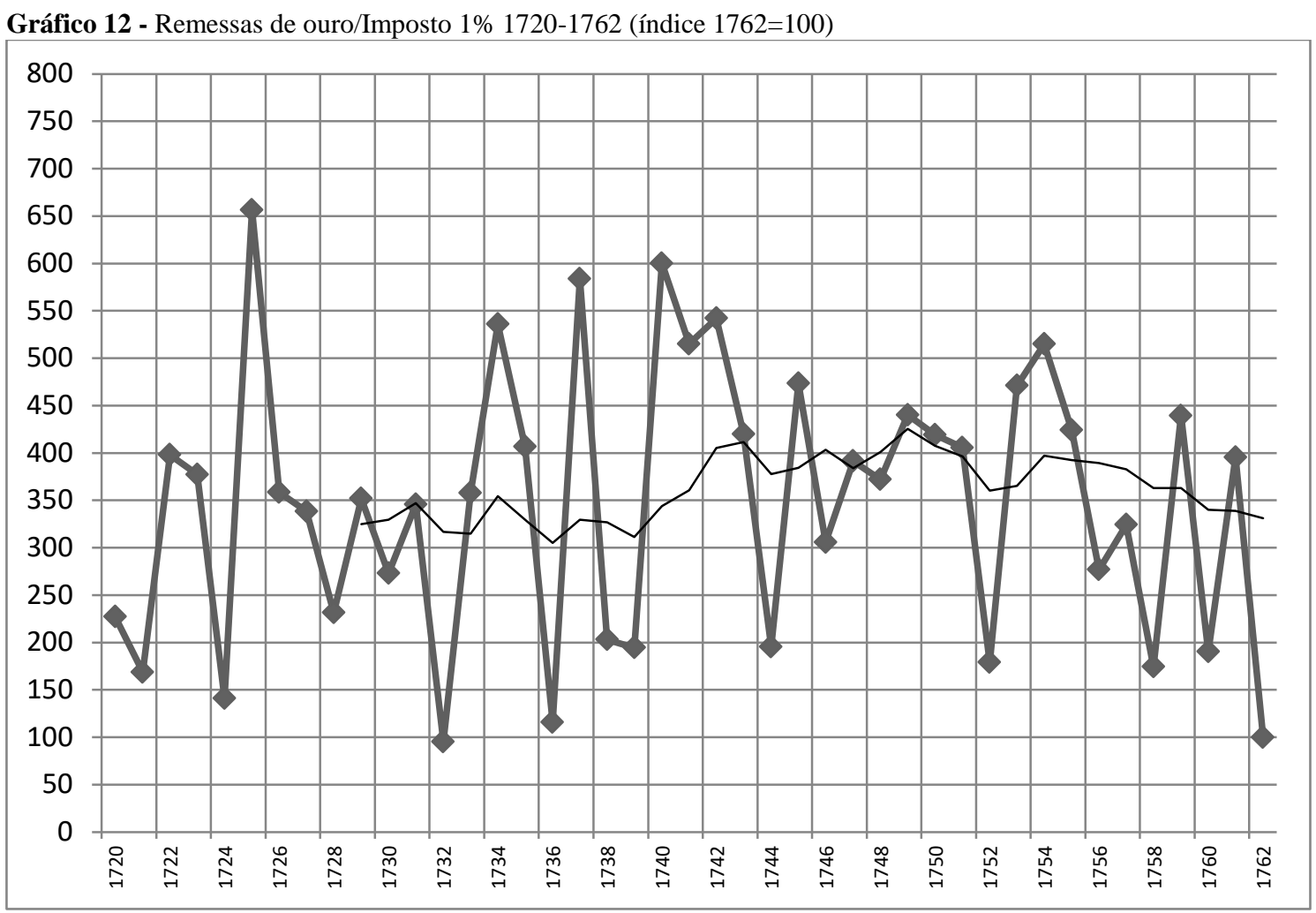

Fonte: Gabinete de História Económica e Social - https://aquila4.iseg.ulisboa.pt/aquila/investigacao/ghes/investigacao/projetoscoordenados-pelo-ghes/o-ouro-do-brasil:-remessas-e-agentes,-1720-1807 (acesso em 11/07/2016). Apud COSTA, Leonor Freire; ROCHA, Maria Manuela; SOUSA, Rita Martins de. O ouro do Brasil, 1700-1807, Lisboa, Imprensa Nacional - Casa da Moeda, 2013.

No gráfico 12 observamos alto patamar no índice de remessas, tendendo de certa forma a uma produção constante se observarmos a linha tendencial inserida. Esta forma de análise por índices evidencia o período de queda que nossa data de referência está inserida, 1762, bem como mostra que a produção aurífera está sujeita a grandes variações de um lançamento a outro. Tal fato justifica a inserção da linha tendencial de médias móveis $^{23}$, para que possamos apreender o movimento tendencial do multiplicador, de forma mais duradoura. O ponto de inflexão provocado pela marca referência do índice, ao final deste gráfico, evidencia este auge produtivo, que conhecerá sua derrocada no período representado pelo gráfico seguinte:

\footnotetext{
${ }^{23}$ Agora com período mais largo, 10.
} 


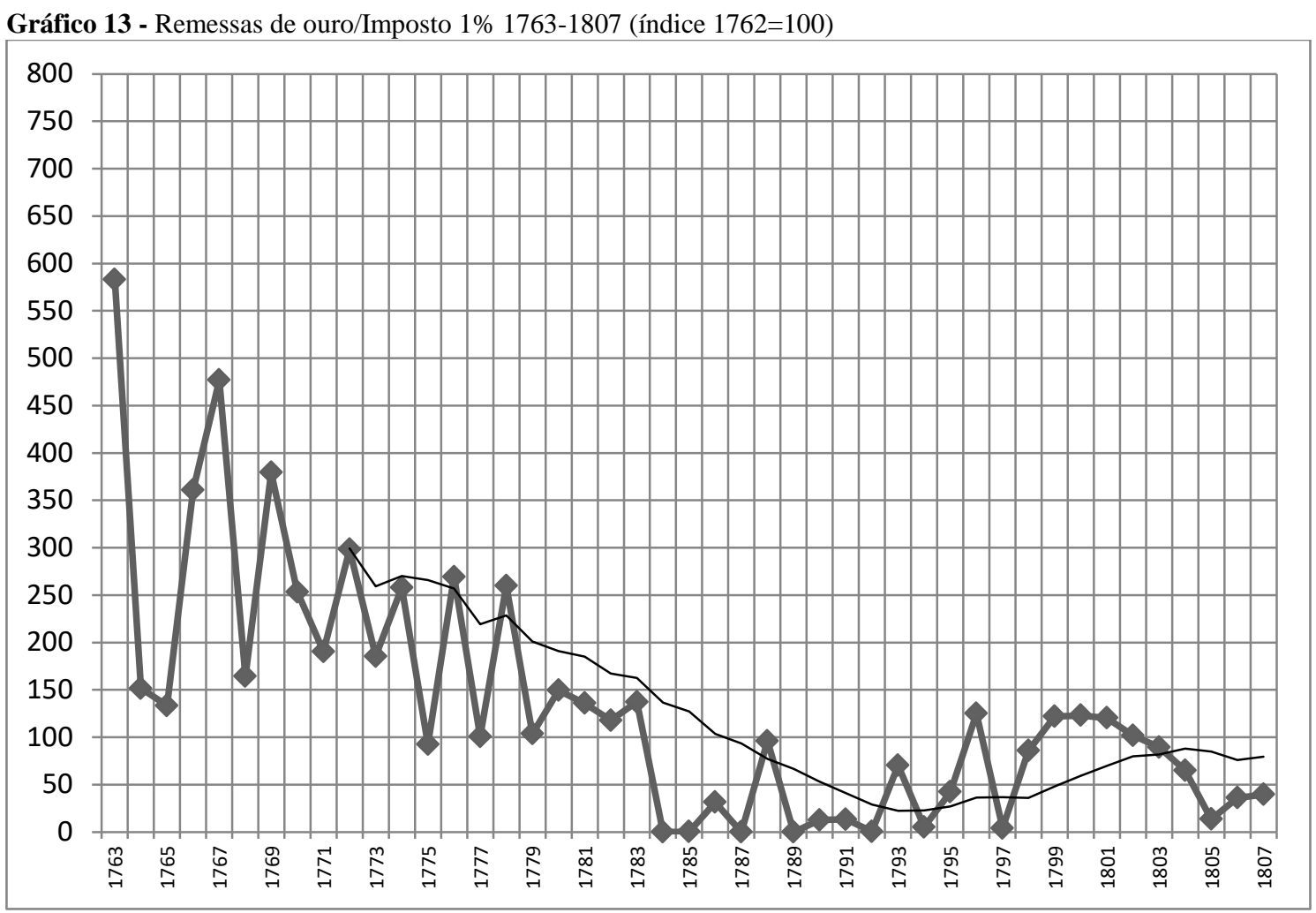

Fonte: Gabinete de História Económica e Social - https://aquila4.iseg.ulisboa.pt/aquila/investigacao/ghes/investigacao/projetoscoordenados-pelo-ghes/o-ouro-do-brasil:-remessas-e-agentes,-1720-1807 (acesso em 11/07/2016). Apud COSTA, Leonor Freire; ROCHA, Maria Manuela; SOUSA, Rita Martins de. O ouro do Brasil, 1700-1807, Lisboa, Imprensa Nacional - Casa da Moeda, 2013.

A queda nas remessas de ouro se pronuncia em meados da década de 1750, chegando aos seus níveis mais baixos a partir da década de 1780 (Gráfico 13). O esgotamento dos veios auríferos em Minas Gerais remete a uma profunda desaceleração nos rendimentos dos dízimos (ver Anexos, Tabela 7), seguida por um período de estagnação, que observaremos com mais vagar no próximo capítulo. Interessante observar que para além da derrocada da capitania de Minas Gerais, o ouro tinha em seu movimento de escoamento pelos portos certo efeito em outras capitanias, principalmente Rio de Janeiro e Bahia, esta última com produção própria um pouco tímida. ${ }^{24}$ Sobre o movimento do transporte nos portos, podemos observar os diferentes patamares:

\footnotetext{
${ }^{24}$ Existe um tópico específico sobre a produção baiana em PINTO, Virgílio Noya, O ouro brasileiro... Op. cit., p. 81-85.
} 
Gráfico 14 - Remessas de ouro/Imposto 1\% provenientes da Bahia, Pernambuco e Rio de Janeiro 1720-1807 (em contos de réis)

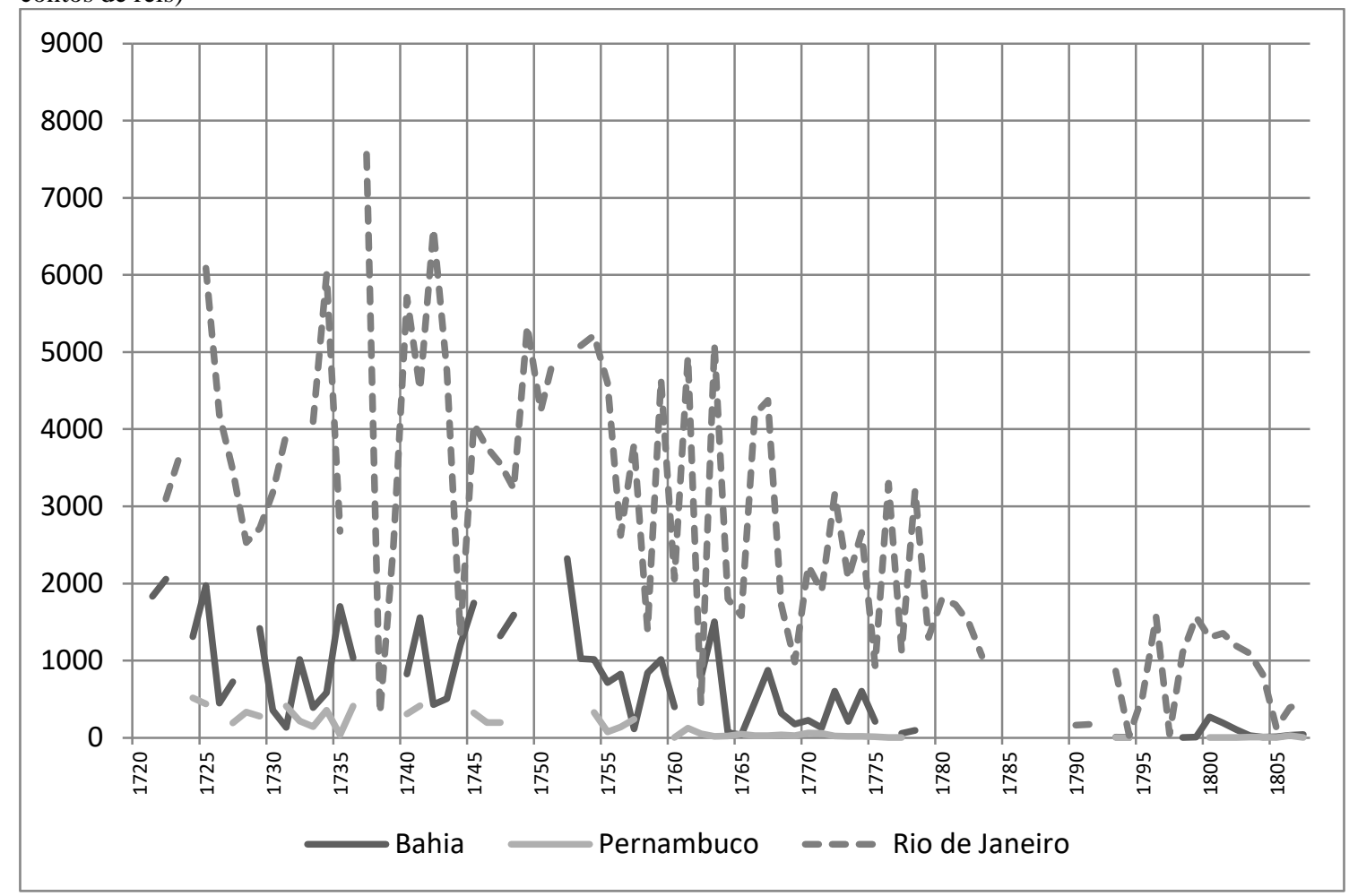

Fonte: Gabinete de História Económica e Social - https://aquila4.iseg.ulisboa.pt/aquila/investigacao/ghes/investigacao/projetoscoordenados-pelo-ghes/o-ouro-do-brasil:-remessas-e-agentes,-1720-1807 (acesso em 11/07/2016). Apud COSTA, Leonor Freire; ROCHA, Maria Manuela; SOUSA, Rita Martins de. O ouro do Brasil, 1700-1807, Lisboa, Imprensa Nacional - Casa da Moeda, 2013.

Destarte, nossa atenção é apreendida com o fato de que o transporte substantivo das cargas do ouro se fazia por meio dos portos do Rio de Janeiro. A diferença nos montantes aferidos chega a ser de quase quatro vezes no ano de 1737, por exemplo, se comparamos as remessas do Rio de Janeiro em relação à Bahia. Importante destacar que este domínio no escoamento, relacionado à proximidade geográfica entre a zona mineradora e o porto fluminense, pode explicar parcialmente a mudança do eixo econômico da colônia de Salvador para o Rio de Janeiro. Esta alteração pode ser identificada nas curvas dos dízimos (Anexos, Tabelas 1 e 5), que serão largamente abordados no capítulo posterior. Não obstante, após o declínio da atividade mineradora, as remessas do Rio só experimentarão níveis tão baixos quanto os da Bahia somente no ano de 1786, quando caem abaixo dos 500 contos de réis, enquanto que a queda na Bahia ocorre desde 1768, quando atingiu patamar de 318 contos. Em Pernambuco o volume é ainda menor, nunca ultrapassando os 516 contos, caindo a níveis abaixo dos 100 contos de réis no início da década de $1760 .^{25}$

\footnotetext{
${ }^{25}$ Para os valores detalhados ano a ano, consultar tabela "valores_e_indices" no CD-ROM.
} 
Em linhas gerais, em relação às remessas de ouro durante o século XVIII (Gráfico 11), temos então: entre 1720 e 1737, a tendência é ascendente, destacando-se o auge no ano de 1725; entre os anos de 1738 e 1754, a tendência é de estagnação, contudo em alto patamar, na casa dos 4.000 contos; entre 1755 e 1769, nota-se uma tendência à queda, porém com médias consideráveis na casa dos 2.500 a 3.000 contos; já entre os anos de 1770 e 1794 assistiu-se uma queda vertiginosa nas remessas de ouro; entre 1795 e 1807 houve uma tímida recuperação, não ultrapassando a casa dos 1.500 contos em 1801, seguida novamente uma tendência negativa até 1807.

\section{A ascensão do primo pobre ${ }^{26}$}

Funcionando como espelho invertido da produção sacarina, a fumicultura demandava áreas normalmente descartadas para o plantio da cana - ou esgotadas por este - e se articulava às produções ligadas à subsistência e aos pequenos produtores. Sua configuração em relação aos tamanhos das plantações e condições do solo diferia frontalmente ao negócio da cana, o que de certa forma privilegiava os pequenos produtores. Fora isso, nas mesmas áreas onde o tabaco era cultivado a mandioca também poderia ser plantada. ${ }^{27}$ Desta forma, percebemos então como que as atividades produtivas dos espaços coloniais se complementam de forma coordenada. O tabaco se mostrou um gênero de suma importância nas articulações econômicas do Império, dada sua utilização no tráfico de escravos compondo uma cesta com os diferentes produtos demandados por ele, garantindo certas vantagens aos homens de negócios estabelecidos na colônia ${ }^{28}$, além de atender as demandas do próprio mercado europeu. Vejamos a flutuação dos valores das importações do tabaco no gráfico a seguir:

\footnotetext{
${ }^{26}$ Tomamos emprestado o título de um artigo de Gustavo Acioli, publicado na revista Saeculum (João Pessoa) em jan./jun. de 2005, A ascensão do primo pobre: O tabaco na economia colonial na América Portuguesa - um balanço historiográfico.

${ }^{27}$ ACIOLI, Gustavo. Negócio da Costa Mina... Op. cit., p. 97.

28 "Portugueses reinóis, estabelecidos nos principais portos do Brasil, passaram a fazer tráfico com a África utilizando, no século XVII, gêneros da terra: cachaça e tabaco juntamente com as demais manufaturas demandadas em África.” ACIOLI, Gustavo. Negócio da Costa Mina..., Op. cit., p. 84.
} 


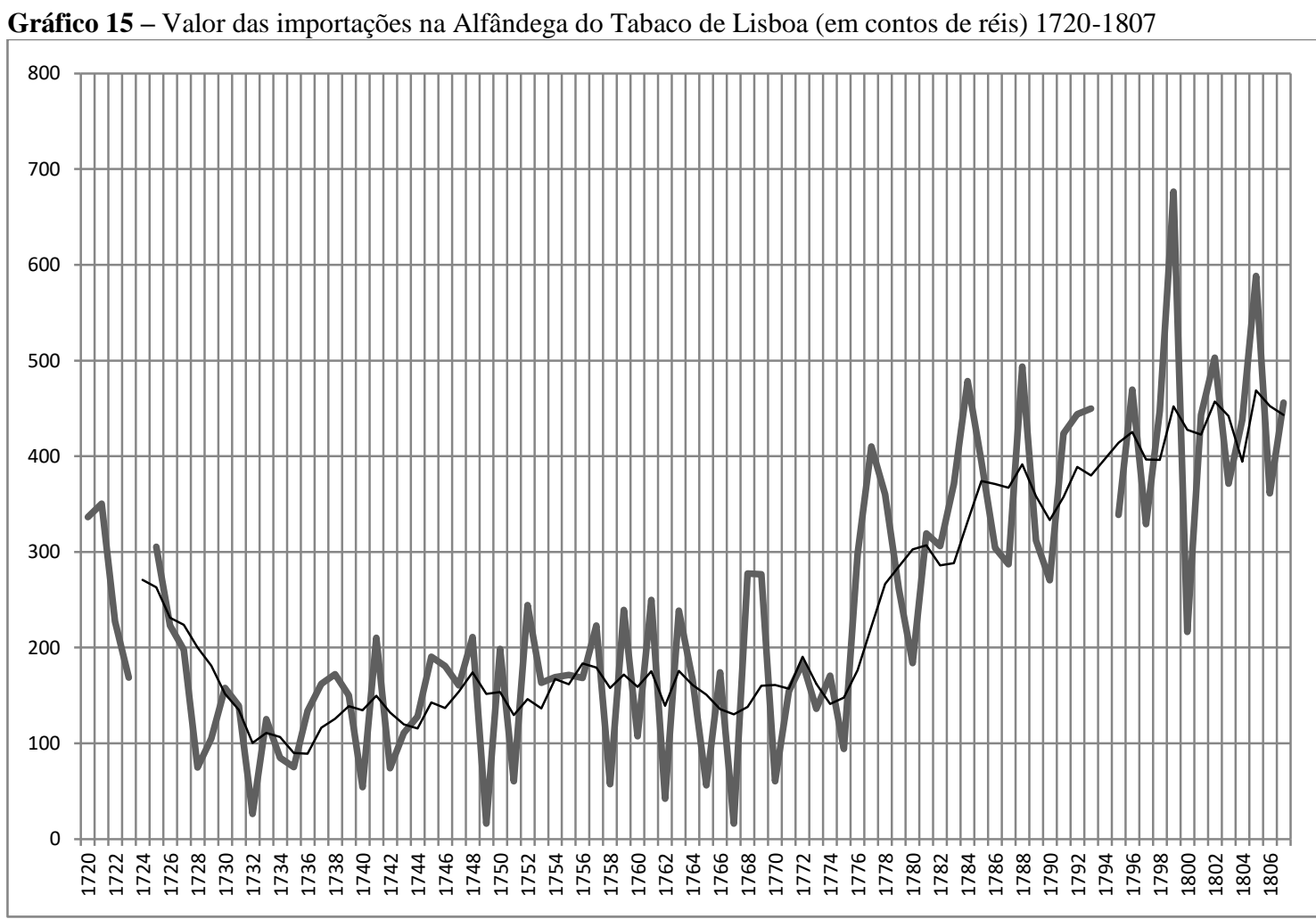

Fonte: NARDI, Jean Baptiste, O Fumo Brasileiro no período colonial, São Paulo: Brasiliense, 1996, apêndice 1.1, p. 366-68; apêndice 5.3 , p. $405 .^{29}$

No primeiro período, até 1732 , uma série de fatores influenciou a queda relativa nos montantes. Primeiramente, o próprio estabelecimento dos direitos de entrada e do monopólio ainda estava gerando efeitos negativos nos preços, o que desanimava os lavradores. Podemos levar em conta também a concorrência do fumo da Virgínia. Uma variação nos preços, de 1.350 para 900 réis, influenciou bastante essa queda no total. Essa fase descendente já havia sido identificada por Nardi, desde o ano de 1699, a qual denominou como estagnação relativa. ${ }^{30}$

A fase seguinte é marcada por altas e baixas, mas a partir das médias, constatase uma tendência à estagnação. Esta pode ter origens tanto na manutenção dos preços baixos da arroba, quanto na média de produção. Uma conjuntura de alta concorrência do

\footnotetext{
${ }^{29}$ No Gráficos 15, elaborado a partir dos dados de Jean Baptiste Nardi , utilizamos uma linha de médias móveis igual a cinco tanto para percebermos melhor as flutuações sem as oscilações tradicionais da variação das quantidades transportadas, quanto para seguir o próprio autor, que indica os preços de Lisboa em médias quinquenais. Para a elaboração do Gráfico utilizamos os dados do movimento de importação da Alfândega do Tabaco de Lisboa, donde o volume aferido refere-se ao fumo oriundo do Brasil, multiplicados pelo preço médio quinquenal de Lisboa. A escolha deste valor de preço se dá devido ao fato de que os preços da Bahia possuíam muitas lacunas e também por ocasião do comercio direto da Bahia com a Costa da Mina. Sendo assim, o montante aferido nos parece mais condizente com as relações entre os dados e para nosso fim, que é o de produzir mais um indicativo do movimento da economia Atlântica. Cf. NARDI, Jean Baptiste, O Fumo Brasileiro no período colonial, São Paulo: Brasiliense, 1996, apêndice 1.1, p. 366-68; apêndice 5.3, p. 405.

${ }^{30}$ NARDI, Jean Baptiste, O Fumo Brasileiro... Op. cit., p. 336-38.
} 
fumo anglo-americano e de maior controle sobre a produção e comercialização (limitação de preços no Brasil, alta nos direitos em Lisboa), contribuiu para esta situação. E mesmo as medidas liberalizantes nas décadas de 1750-60 terão seus efeitos apenas em meados de $1770 .^{31}$

Podemos observar que o movimento do tabaco decola a partir do ano de 1776. Neste ano, além do preço médio por arroba subir de 900 réis para 1.100, as quantidades que chegam à Alfândega de Lisboa crescem em 100.000 arrobas. Nardi define este período como "arrancada". Entre suas causas estaria a decadência do sistema colonial, o processo de independência dos Estados Unidos e medidas tomadas na própria metrópole, como a abolição parcial do direito de entrada e a permissão de se importar de fumo de menor qualidade para a Europa. ${ }^{32}$

Assim como o açúcar, o tabaco se aproveitou do contexto causado pelos conflitos militares. O tabaco brasileiro (leia-se, baiano) desponta justamente no período de independência das treze colônias americanas. Algo muito similar ao que aconteceu com o algodão. Não a toa que desde a segunda metade do XVII, a produção fumageira já despertava interesses por parte da Coroa, tendo em vista que desde esse período houve esforços no sentido fiscal e de monopolização do comércio. ${ }^{33}$

No Reino, apesar das flutuações no primeiro quartel do XVIII, o estanco do tabaco cresceu de forma significativa até 1755, quando atingiu mais do que o dobro que se arrecadava em 1702. ${ }^{34}$ A tendência geral do tabaco - tanto do lado da produção, quanto dos preços - foi de expansão acentuada a partir do terceiro quartel do Setecentos até a primeira década do século XIX, quando a partir de 1811 o volume das importações da Alfândega do Tabaco de Lisboa regride aos níveis pré $1760 .{ }^{35}$ Portanto, percebemos três movimentos claros nas flutuações da produção do fumo ao longo do Setecentos: entre 1720 e 1727, de tendência descendente; entre os anos de 1728 e 1775, observamos uma estagnação; por fim, entre 1776 e 1807, há um movimento ascendente.

\footnotetext{
${ }^{31}$ Ibidem, p. 342.

32 Idem.

${ }^{33}$ ACIOLI, Gustavo, Negócio da Costa da Mina... Op.cit., p. 93-8.

${ }^{34}$ SALVADO, João Paulo. O Estanco do Tabaco em Portugal: Contrato Geral e Consórcios Mercantis (1702-1755). IN LUXÁN, Santiago de., Política y Hacienda del Tabaco em los Impérios Ibéricos (siglos XVII-XIX), Madrid: Centro de Estudios Políticos y Constitucionales, 2014, p. 144.

${ }^{35}$ Nardi não desenvolve muitas linhas a respeito deste último período, chamado por ele de "Última fase (1808-1830)". Em linhas gerais, atribui esta queda no movimento da Alfândega do Tabaco de Lisboa um incremento no comércio direto com a Costa da Mina principalmente no período pós 1815, no fluxo clandestino dada a proibição do tráfico de escravos. NARDI, Jean Baptiste, O Fumo Brasileiro... Op. cit., p. 343.
} 


\section{A "instituição peculiar"}

Por fim, chegamos ao último, mas não menos importante, ponto de nossa análise das atividades coloniais definidoras deste século XVIII. Se pudéssemos apontar alguma delas como interconectada a todas as outras, esta reside na mão de obra e suas formas de obtenção: a escravidão. Entendemos a escravidão como uma instituição econômica de primeira grandeza, totalizante, definidora das relações sociais e econômicas, calcada na relação da produção mercantil dominante. ${ }^{36}$

Nas páginas que se seguem, procuraremos expor dados que aportem mais indícios e tendências dos movimentos conjunturais da economia colonial. Para isso, apresentamos os seguintes gráficos, que dão conta das importações gerais de escravos para as três localidades mais importantes da América Portuguesa: Bahia, Pernambuco e Rio de Janeiro, seguindo o padrão que temos estabelecido até aqui para as demais atividades. Esta análise está ligada às outras já apresentadas e procura complementar as hipóteses, principalmente acerca do comportamento das curvas do açúcar (Gráficos 3 e 4, referentes à Bahia; Gráficos 5 e 7, dando conta do Rio de Janeiro).

\footnotetext{
${ }^{36}$ TOMICH, Dale W., Pelo Prisma da Escravidão... Op. cit., p. 52; NOVAIS, Fernando. Aproximações... Op. cit., p. 365.
} 
Gráfico 16 - Importações Gerais de Escravos (Bahia, Pernambuco e Rio de Janeiro agregados) 1720-1807

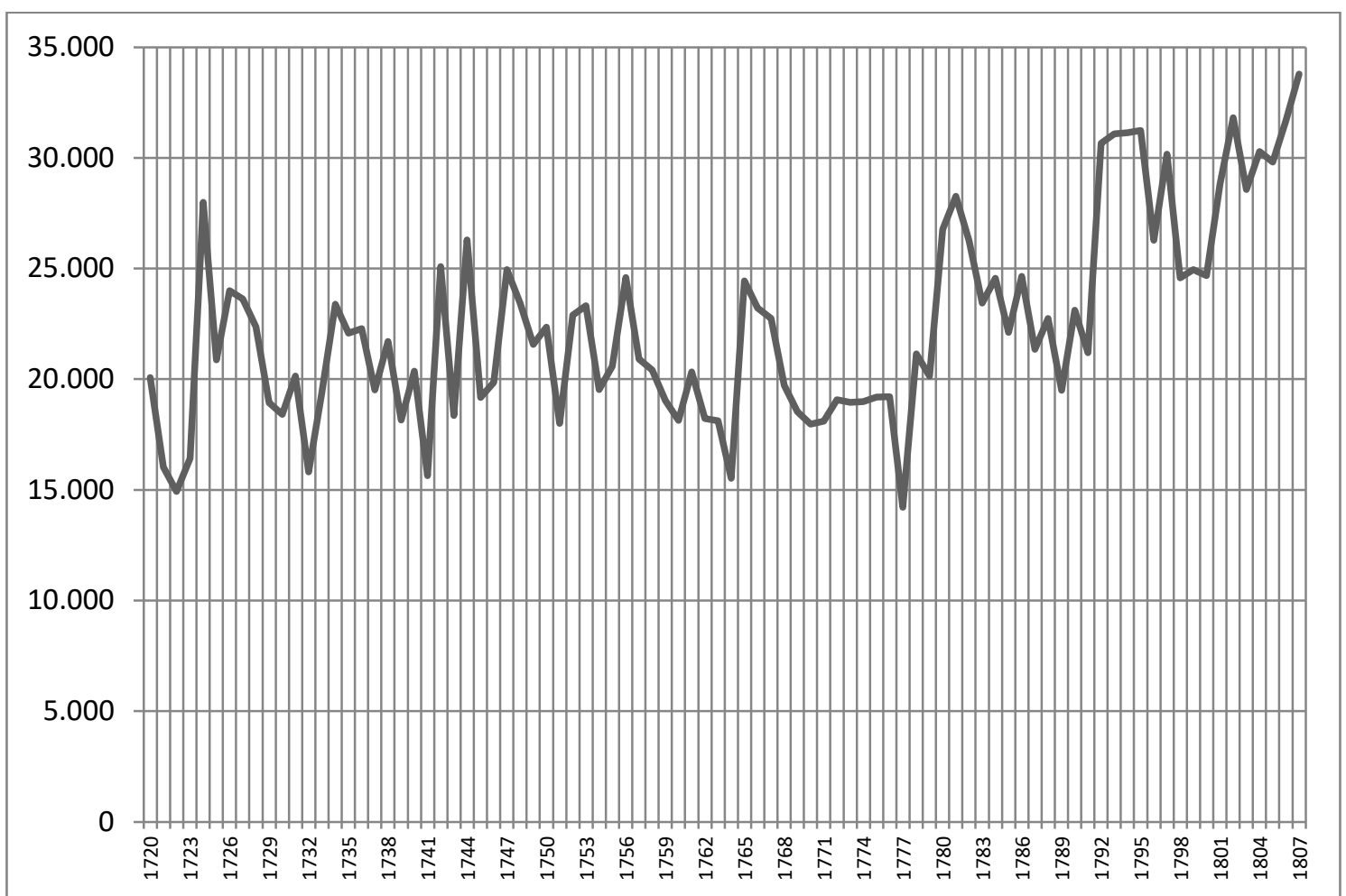

Fonte: ELTIS, David, et. al. "Voyages: The Trans-Atlantic Slave Trade Database" (2008), www.slavevoyages.org (consultado em $12 / 11 / 2012)$

Podemos perceber que as importações seguem um ritmo ascendente, ainda que com grandes variações (Gráfico 16). No início do Oitocentos observamos seu auge, chegando a mais de 33.000 peças, mais do que o dobro de seus pontos mais baixos, experimentados abaixo da casa dos 15.000 escravos, nos anos de 1722 e 1777. Observemos a seguir um gráfico com estes dados desagregados, mostrando as curvas de Bahia, Pernambuco e Rio de Janeiro separadamente e em seguida passamos à análise dos dados em visões individuais de cada movimento. 
Gráfico 17 - Importações Gerais de Escravos (Bahia, Pernambuco e Rio de Janeiro) 1720-1807

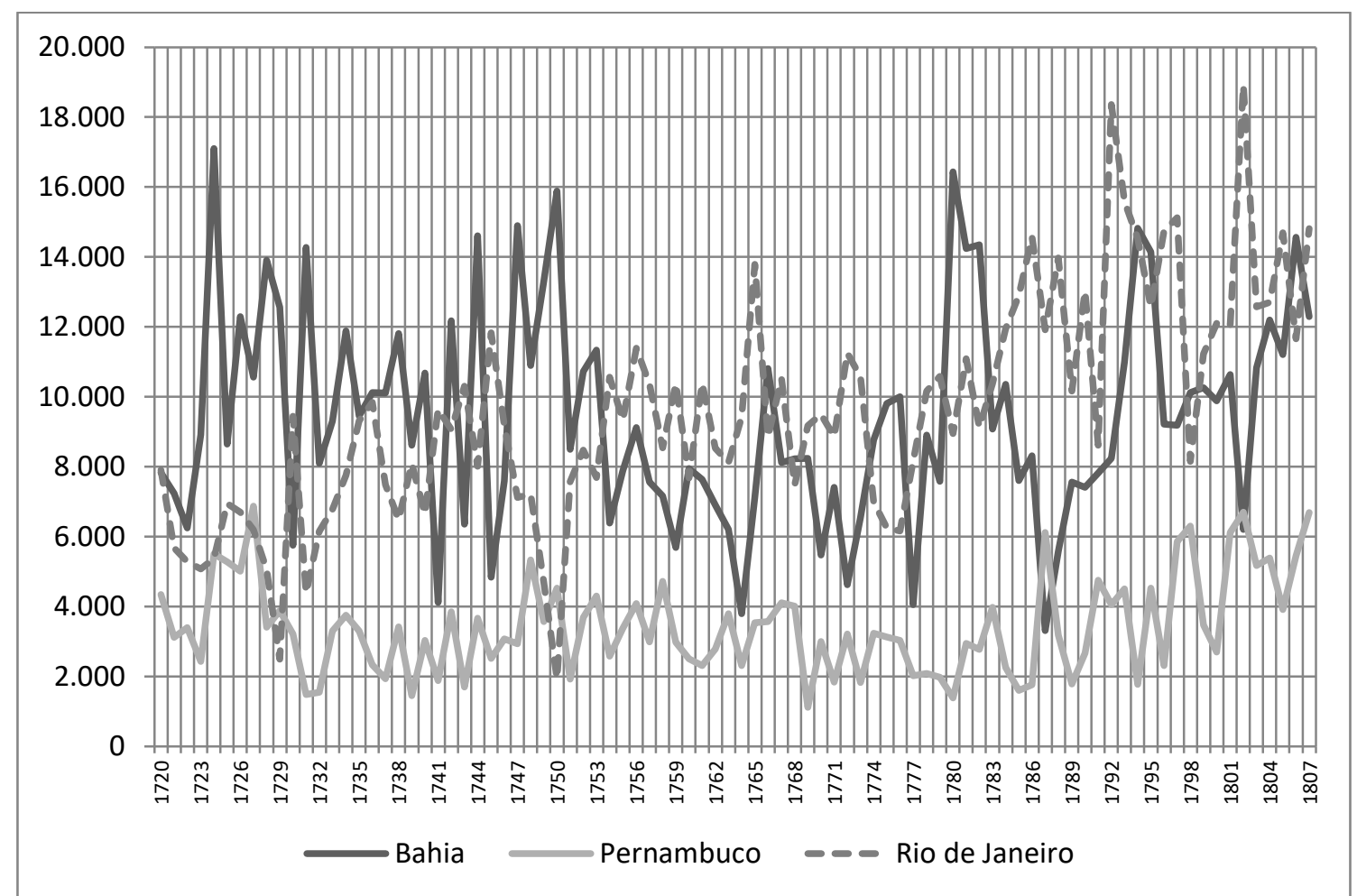

Fonte: ELTIS, David, et. al. "Voyages: The Trans-Atlantic Slave Trade Database" (2008), www.slavevoyages.org (consultado em 12/11/2012).

Analisando o gráfico 17, comecemos pelas variações baianas. Vemos que a queda que resultou no segundo menor ponto da série inicia-se após 1760, mas as informações contidas no gráfico nos indica esta tendência à queda desde ao menos 1750. Ao longo do século XVIII houve uma dominância nas importações por duas praças: Bahia e Rio de Janeiro. Em um primeiro momento, a Bahia domina praticamente todos os anos. No momento seguinte, a partir da década de 1760, esta dominância passa para o Rio de Janeiro, explicitado a seguir pelo gráfico 18. 
Gráfico 18 - Importações Gerais de Escravos (Bahia, Pernambuco e Rio de Janeiro) 1720-1807 (por década)

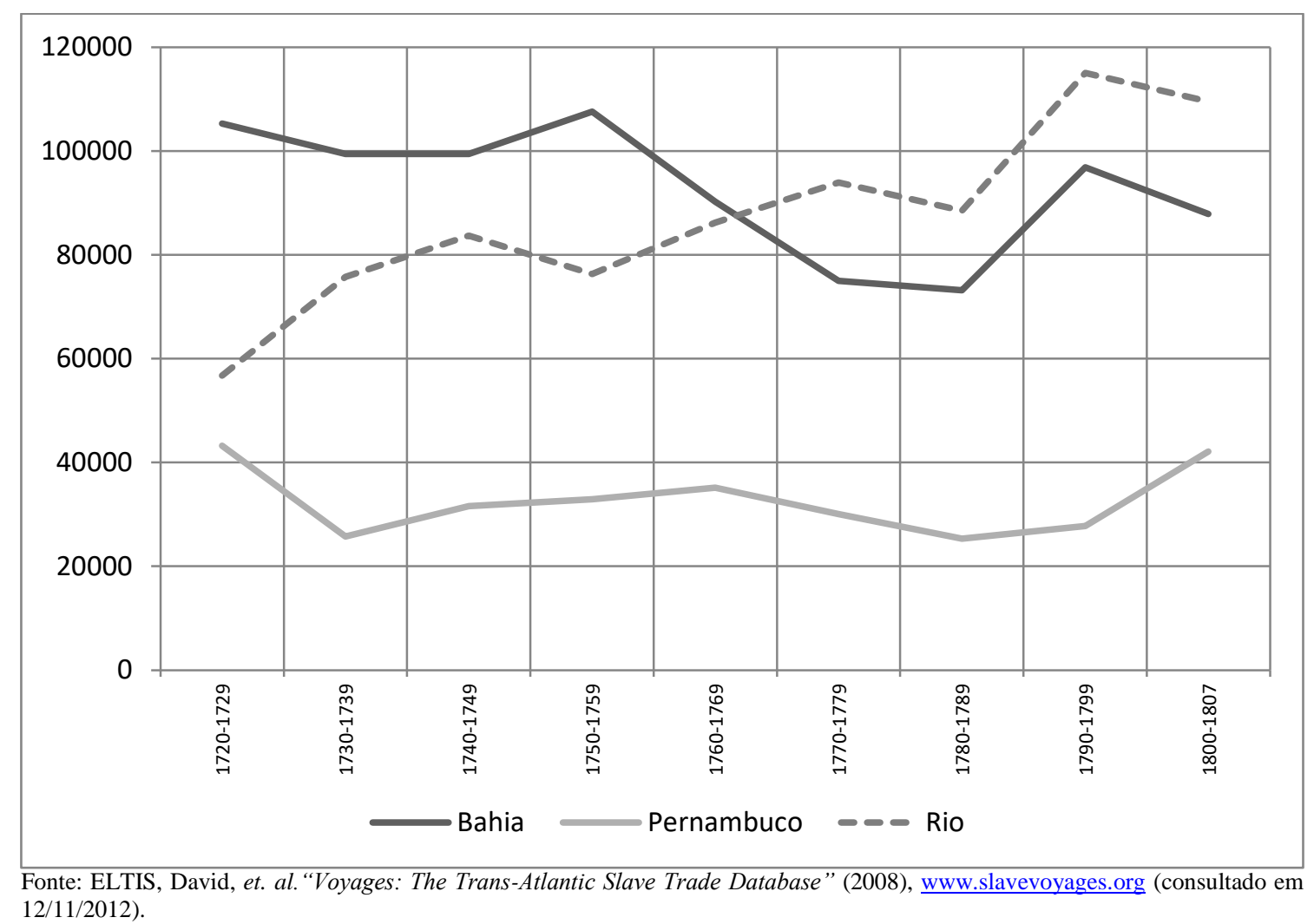

Sendo assim, temos os seguintes movimentos: 1720-1745, ascendente, seguido de leve tendência de queda; 1746-1764, movimento similar ao anterior, iniciando com uma tendência ascendente e em seguida, descendente: até este último movimento, mais precisamente até o ano de 1753, a Bahia liderava os números de importação de escravos, respondendo com aproximadamente $49 \%$ das importações, sendo que no ano seguinte, respondendo com apenas 33\%, perde seu lugar para o Rio de Janeiro, que por sua vez chega à participação de $54 \%$ das peças entradas. Esta diferença poderia dar-se por uma diminuição geral das importações, o que de fato acontece, já que no ano de 1753 mais de 23 mil pessoas são importadas, ao passo que no ano seguinte, apenas 19.523. Porém, a proeminência do Rio de Janeiro perdurará, tendo a Bahia o superado apenas em um ano neste período, em 1760.

Já em 1765-1776, houve leve estagnação com viés de alta, com a Bahia responsável pela maior contribuição em 1766 e 1768; 1777-1794, alta aguda, começando em 1780 um período de três anos em que a Bahia tomará novamente a dianteira das importações, passando por um movimento descendente com leve recuperação nos últimos seis anos; 1795-1807, descendente, com leve estagnação: 
queda em 1802, mas recuperação e tendência de alta ao fim da série, e dois anos com a maior participação, 1798 e 1807.

A respeito de Pernambuco, verificamos que os níveis de importação de escravos encontram-se bem abaixo dos aferidos na Bahia e Rio de Janeiro. Observamos flutuações mais suaves. Analisando as conjunturas temos que entre os anos de $1720 \mathrm{e}$ 1731 há uma tendência negativa, sendo 1731 a menor participação da capitania nos percentuais totais de importação de escravos. Assistimos uma estagnação entre os anos de 1732 e 1748. Entre 1749 e 1780 a estagnação continua, entretanto com viés de baixa. Por fim, de 1781 a 1807, mesmo com flutuações bruscas, a tendência é claramente de alta. Esse aumento das importações de escravos, assistido nesse período final, ajudam a entender a recuperação da produção do açúcar de Pernambuco, após o início dos conflitos para independência do Haiti e, principalmente, com o fim da companhia monopolista de comércio, em 1780. Além do desenvolvimento da cultura algodoeira que passa a representar as mais avultadas rendas da capitania também nesse período, a partir do terceiro quartel do século XVIII. ${ }^{37}$

Sendo assim, temos: 1720-1731, descendente, média de 20\% de participação nos primeiros anos, tendo o mínimo de $13 \%$ em 1723, atingindo um maior patamar de $29 \%$ em 1727, finalizando o período com viés descendente, com o ano de 1731 respondendo um dos menores coeficientes de participação de Pernambuco nos totais, 7\%, média geral neste período de 20\%; 1732-1748, média de participação de 14\%, estagnação, com viés de alta; 1749-1780, estagnação, com viés de baixa; 1781-1807, variações bruscas ano a ano, com tendência de alta, mesma média do período anterior, $15 \%$ de participação nos totais.

O caso do Rio de Janeiro é o que comporta a maior diferença entre o valor mínimo aferido e o máximo: 1.937 para 18.908. Alguns movimentos mais claros podemos depreender: alta do início da série até 1745, seguida por uma brusca queda até 1750, em que sua recuperação posterior sugere uma leve estagnação seguida por uma alta mais consistente até 1792, sofrendo nova queda até 1798 . Em toda a série, a participação do Rio de Janeiro esteve na média dos 43\%, tendo seus menores valores entre 1747 e 1750, anos em que computa 29\%, 31\%, 22\% e 9\%, respectivamente. A estes anos, ainda no período de dominância total da Bahia em relação às importações,

\footnotetext{
${ }^{37}$ Cf. RIBEIRO JÚNIOR, José, A economia algodoeira em Pernambuco, Da Colônia à Independência.IN Revista Brasileira de História, São Paulo 1, 2, set. 1981, pp. 236-38.
} 
devemos levar em conta um crescimento nas importações desta em relação aos anos anteriores, tendo dobrado seu número em relação a 1746.

De tal modo: 1720-1730, descendente, média ainda bem abaixo daquela que experimentará para a série, 28\%. O ano de 1730 é atípico, tendo uma alta bastante grande nas importações do Rio, em detrimento da queda dos números da Bahia; 1731 1745, ascendente, média de 40\% de participação para o período, com 1731 respondendo pela participação mais baixa, $22 \%$ e dois anos em que se alcançaram as maiores participações até então, 62\%, em 1741 e 1745; 1746-1772, inicia com queda aguda, contendo o pior ano da série, 1750, com 1.937 importações, seguido de recuperação. De certa forma, podemos apontar que os últimos quatro anos foram fundamentais na mudança do eixo das importações de escravos, invertendo-se da Bahia para o Rio de Janeiro. Neste quadriênio, a média de participação situou-se em 42\%, e o ano de 1754 registra o maior número absoluto de peças importadas pelo Rio até então, 10.560. A maior parte, os últimos 17 anos, estagnação, com pico em 1765, maior média relativa dos períodos analisados até este ponto, 48\%; 1773-1798, início descendente, acompanha-se uma queda geral das importações, até 1777 os números totais caem abaixo do patamar das 20.000 peças, quando começa-se a perceber uma recuperação. Em números relativos, 1786 atinge 14.569 peças, 59\% dos totais. O último quadriênio é descendente, queda nos números absolutos do patamar de 14.000 peças, participação média de 53\%; 1792-1807, pico em 1792, seguido de queda abrupta até 1798. Ainda que este primeiro período seja de queda nos números absolutos, parte-se de patamares muito altos, somando 99.079 peças importadas, encerrando-se a série com viés de alta, seguida de estagnação.

Com a análise dos dados apresentados até este momento, percebemos um domínio até meados da década de 1750 do que chamamos de região Norte - composta por Bahia e Pernambuco - sobre e a região Sul - capitaneada por Rio de Janeiro e Minas Gerais. Essa mudança de eixo pôde ser observada no gráfico 17, que trata da participação nas importações gerais de escravos. Já em relação ao ouro de Minas Gerais percebemos que foi através das remessas desse metal que o Rio de Janeiro se beneficiou e conseguiu se alcançar uma posição de destaque entre as capitanias da América 
portuguesa. O impulso gerado pelo ouro na economia carioca não se esgotou com a decadência aurífera, pelo contrário, a economia do Rio se aproveitou (ou foi motor) da alteração institucional, tornando-se a capital do Estado do Brasil em 1763. Sendo assim, na segunda metade de nosso recorte, de 1763 a 1807, a dominação passou ao eixo sul da colônia, com o Rio de Janeiro a capitanear a economia da América Portuguesa, e se sustenta como tal até o final de nosso recorte, como demonstrado nas curvas por década, do Gráfico 18. O escoamento da produção aurífera pela Bahia, ainda que nunca tenha sido em altos patamares, experimenta de forma mais precoce a diminuição nos afluxos, com valores que serão apenas aferidos em finais da década de 1760 no Rio de Janeiro, onde o escoamento se dava de forma majoritária, qual ressaltado no Gráfico 14.

Assistimos uma série de movimentos, que ao final do século XVIII apontam para uma recuperação geral da economia portuguesa no Atlântico. A variação negativa nas primeiras décadas de nosso recorte - influenciada pela queda no preço do açúcar nas décadas de 1730 e 1740 - é compensada pelo aumento da extração aurífera neste mesmo período: esta atinge seu ápice no final da década de 1730, mantendo as altas remessas até inícios da década de 1750. A recuperação dos preços do açúcar em Londres e Amsterdã se dá a partir de finais da década de 1730, algo que animou novamente a produção baiana, valorização sentida já no início da década seguinte, inclusive na metrópole, recuperando as perdas destas na relação com o ouro (Gráficos 11, 9, 3 e 1).

O que pensamos estar claro em relação aos preços do açúcar é a relação de hierarquização entre as diferentes praças do mercado mundial. Capitaneadas por Amsterdã, que possui os maiores preços, e seguida por Londres, diferenças que pudemos perceber pela conversão dos valores ao equivalente comum, a prata. Em Lisboa, os preços sempre são menores, assim como os preços coloniais, que são pressionados pelos mercadores metropolitanos, tal qual explanado no Gráfico 8.

Completando o quadro, pudemos observar, com o auxílio do Gráfico 15, que mesmo com os preços do tabaco estáveis em Lisboa, houve um incremento impressionante na produção do gênero a partir da década de 1770. Em termos conjunturais, existem indícios de que a América Portuguesa da segunda metade do século XVIII vale mais comercialmente do que, mais ou menos, nos 30 anos anteriores. Estes indícios e mudanças serão abordados com mais vagar no próximo capítulo, quando, debruçando-nos acerca da questão da fiscalidade, responderemos e proporemos mais perguntas sobre o comportamento das conjunturas fiscais do Atlântico e suas respostas globais ou locais. 


\title{
Capítulo III - O império da Fiscalidade
}

\begin{abstract}
"Pelo que temos dito até agora, não haverá quem possa duvidar de ser hoje o Brasil a melhor e mais útil Conquista, assim para a fazenda real como para o bem público, de quantas outras conta o Reino de Portugal, atendendo ao muito que sai destes portos que são minas certas e abundantemente rendosas."1
\end{abstract}

O jogo de palavras presente no título de nosso trabalho e também neste capítulo, remete ao crescente "domínio" da tributação direta no século XVIII em relação às rendas aferidas pela Coroa. Este domínio está diretamente ligado à ampliação dos espaços coloniais e de uma mudança no eixo produtivo da América Portuguesa, sobretudo a partir da década de 1760 . Isso porque nessa mesma década houve a criação do Erário Régio e a transferência da capital de Salvador para o Rio de Janeiro. Procedemos ao cerne de nosso estudo, explorando as movimentações dos valores de arrematação das dízimas das alfândegas e dos dízimos das capitanias da Bahia, Pernambuco, Rio de Janeiro e Minas Gerais. ${ }^{2}$ Completamos nossas séries de dados com os dízimos de São Paulo e Rio Grande de São Pedro do Sul.

\section{Os dízimos e as dízimas}

Em Portugal, uma série de privilégios eclesiásticos estava sob a jurisdição da Ordem de Cristo. Como vimos, esta foi incorporada pela Coroa, que passou a administrar seus rendimentos, como é o caso dos dízimos. Estes foram utilizados como uma espécie de "fluxo de caixa" de suas despesas ordinárias, para além do pagamento das folhas do clero. ${ }^{3}$ Os dízimos consistem em um tributo que incide sobre a produção a uma taxa de $10 \%$. No Estado Português, com as reformas nos forais, se tomaram as

\footnotetext{
${ }^{1}$ ANTONIL, André João. Cultura e Opulência do Brasil por suas Drogas e Minas (primeira edição, 1711). Introdução de notas por Andréa Mansuy Diniz Silva. São Paulo: Editora da Universidade de São Paulo, 2007 (Documenta Uspiana II). p. 302-3.

${ }^{2}$ Nesta última, em vez da dízima da alfândega tomamos sua congênere, as entradas.

${ }^{3}$ Esta característica de extração de réditos para além de sua destinação original aparece "a fim de ajudar a cobrir os déficits na administração geral, como ocorreu nos distritos auríferos de Minas Gerais durante o século XVIII". BOXER, Charles. O Império Marítimo Português. São Paulo: Companhia das Letras, 2002, p. 244.
} 
rendas muito mais como coisa pública, do que em outros casos da colonização do Novo Mundo. ${ }^{4}$

Em relação ao Brasil, "apesar de sua cobrança representar quase exclusivamente o rendimento da produção do açúcar, a decisão sobre quais gêneros recairia a cobrança dependia, evidentemente, do nível de participação deles no comércio." ${ }^{~} 5$ Não obstante, como já apontado, boa parte dos contratos dos dízimos arrematados era retalhada e vendida novamente. Estas porções dos contratos podiam ser minúsculas, chegando a menos de $1 \%$ dos valores dos dízimos de uma capitania. Essa prática foi necessária para que se pudesse facilitar a cobrança nas diversas freguesias, dada a vastidão do território que um contrato poderia abarcar. Também para garantir, de certa forma, uma colaboração das hierarquias locais daquelas sociedades. Assim, se garantia a cobrança da carga fiscal que era elevada, se considerar o conjunto dos impostos. ${ }^{6}$

O que se observa no período que chamamos de centralização dos contratos, a partir de 1720, e mais precisamente com o boom aurífero é a utilização dos tributos régios, dentre eles o dízimo, como modo de extração da riqueza que estava sendo produzida na Colônia e que deveria entrar nos cofres das provedorias locais. Sua função primordial, custear a folha eclesiástica amalgamava-se então ao fim último da colonização em favor da metrópole. Se não transferia rendas desta natureza em metal sonante para Lisboa, ao menos tocava a colonização sem despender recursos do Reino.

Já as alfândegas e a cobrança de seus rendimentos surgiram nos regimentos das Ordenações de Reino e Fazenda de D. João III. ${ }^{7}$ As alfândegas funcionaram em todas as colônias e foram a porta de entrada das mercadorias que vinham de outras partes do Império. Como a maioria dos rendimentos fiscais, sua aplicação era prioritariamente militar, servindo para a construção de fortalezas, por exemplo. Em localidades onde não era possível a instalação das alfândegas, outra cobrança era realizada com a mesma

\footnotetext{
${ }^{4}$ Apenas para exemplificar, havia uma diferença entre os dízimos de Portugal com os dízimos de Buenos Aires, primeiramente em relação à própria constituição da produção, já que em Buenos Aires eram separados gados e grãos enquanto que no Império Português não parece que exista uma diferenciação, mas que substancialmente se dá com a cobrança de outros impostos específicos, como no caso dos couros, carnes verdes e etc. Cf. AZCUY AMEGHINO, Eduardo. Agricultura, ganadería y diezmos em el bispado de Buenos Aires, 1782-1802: uns comparación infructuosa. IN La Otra Historia. Economia, Estado y sociedad en Río de la Plata Colonial, Buenos Aires: Imago Mundi, 2002, passim.

${ }^{5}$ CARRARA, Ângelo, Receitas e despesas da Real Fazenda no Brasil: século XVII...Op. cit., p. 39.

${ }^{6}$ GALLO, Alberto. Op. cit., p. 5.

${ }^{7}$ CARRARA, Ângelo. Receitas e despesas (...) século XVIII...Op.cit., p. 198.
} 
finalidade: as entradas. $\mathrm{O}$ caso de maior rendimento desse tipo de cobrança foi a das entradas das Minas Gerais. ${ }^{8}$

A estrutura de funcionamento das alfândegas era relativamente simples. Todas as mercadorias sofriam tributação de $10 \%$. Entretanto havia algumas que sofriam tributação especial, seja por protecionismo ou por acordos celebrados com a Coroa de Portugal. O Tratado de Methuen, por exemplo, taxou de forma diferenciada produtos oriundos de Inglaterra, que por sua vez tributava de forma diferenciada os produtos portugueses que importavam. Além da dízima, as alfândegas poderiam ser responsáveis pela recolha de impostos sazonais, como os $4 \%$ para a reconstrução de Lisboa e os $3 \%$ para as fragatas, impostos que incidiam nas importações. Em alguns casos, como na Alfândega Grande de Lisboa pagava-se $8 \%$ dos valores das exportações, como direitos de consulado, sujeitos a Casa da Índia. Existiam alguns casos em que se cobravam direitos a $4 \%$, sob efeito de baldeação. ${ }^{9}$

Uma das vantagens dos direitos arrecadados nas alfândegas era que sua cobrança poderia ser feita quase em tempo real. Esta agilidade na arrecadação poderia levar ao contratador, ou à Fazenda quando esta o administrava, a uma resposta melhor em relação ao investimento e despesas da atividade. Assim sendo, ao mesmo tempo em que os contratos da dízima da alfândega tinham mais chances de serem pagos integralmente, comparativamente aos dízimos por exemplo, estes contratos também tinham mais chances de serem administrados com mais eficácia. ${ }^{10}$

Destas fontes de dados podemos retirar diversos indícios do nível de vida das populações ou mesmo avaliar o desempenho das economias e suas relações. ${ }^{11} \mathrm{Da}$ relação dos dízimos é possível apreender os movimentos de ânimo das produções locais, bem como a evolução destas produções. Um exemplo pode estar na relação que estabelecemos com os preços: em períodos de estagnação em que os dízimos apresentam uma subida nos seus valores de arrematação podem representar um aumento

\footnotetext{
${ }^{8}$ As alfândegas são instaladas em portos de mar, sendo assim, nas capitanias em que não se tinha acesso ao litoral, utilizava-se cobrar as entradas. Em menor escala, neste tipo de cobrança podemos citar o caso da capitania de Goiás. Ver anexos, Tabela 8.

9 "O valor da dízima não consistia em $10 \%$ sobre o valor real das mercadorias, mas também não era o resultado de $10 \%$ sobre o valor fixado pela pauta para as diversas mercadorias. Era antes um valor intermédio entre os dois." SILVA, Francisco Ribeiro da. Alfândegas lusas em finais de Setecentos: fiscalidade e funcionalismo. IN O litoral em perspectiva histórica (Séc. XVI a XVIII). Porto: Instituto de História Moderna, 2002, p. 208-12.

${ }^{10}$ GALLO, Alberto. Colóquio Internacional... Op. cit., p. 3.

${ }^{11}$ CARRARA, Ângelo Alves, Para uma história dos preços do período colonial: questões de método IN LOCUS: revista de historia. Juiz de Fora: Programa de Pós-Graduação em Historia/Departamento de História, 2008 v. 14, n.01, p. 191.
} 
da produção total do gênero naquela localidade ou mesmo um processo de diversificação da produção. Com as alfândegas, determinados comportamentos de alta e baixa nas arrematações podem apontar para uma mudança nas pautas de cobrança ou até mesmo um incremento/decréscimo na eficácia da recolha deste tributo, além de poder sugerir o aumento relativo da economia, já que este tributo regula sobre as mercadorias que entram nas capitanias e estas entradas haviam de ser pagas de alguma forma.

Vejamos pormenorizadamente o comportamento de cada uma das localidades estudadas no que concerne aos dízimos e às alfândegas, tentando traçar um panorama geral da economia do Império Português com o auxílio dos dados já discutido no capítulo II.

\section{Bahia}

Foi a cabeça da América Portuguesa até 1763. A Bahia liderou os valores de arrematação dos dízimos até 1730, quando é ultrapassada por Minas Gerais devido à mineração (Gráfico 19). Na dízima da alfândega houve um movimento parecido, porém mais precoce. Em 1726 o Rio de Janeiro toma a dianteira deste arrendamento, condição que manterá por mais de uma década, quando Minas Gerais assume este posto, mantido até 1765 , quando a atividade mineradora declinou. 
Gráfico 19 - Dízimos da Capitania da Bahia 1720-1807 (em contos de réis)

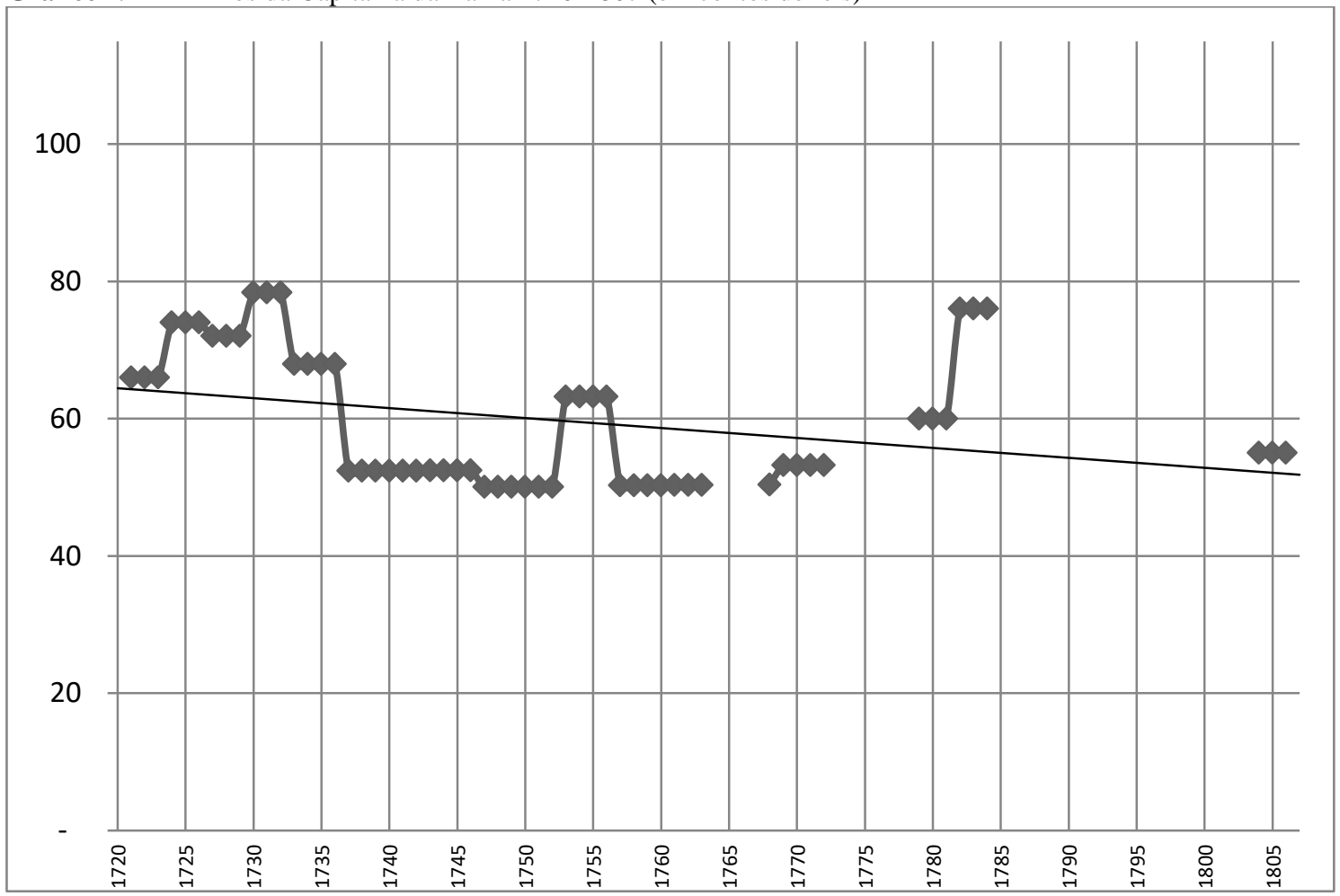

Fontes: PAIVA, A. Banco de Dados dos Contratos do Conselho Ultramarino, 2012; Arquivo Histórico Ultramarino, Administração Central, Conselho Ultramarino, Bahia, Avulsos, Cx. 7, D. 561; Arquivo Histórico Ultramarino, Administração Central, Conselho Ultramarino, Bahia, Avulsos, Cx. 17, D. 1544; Arquivo Histórico Ultramarino, Administração Central, Conselho Ultramarino, Bahia, Avulsos, Cx. 21, D. 1907; Arquivo Histórico Ultramarino, Administração Central, Conselho Ultramarino, Bahia, Avulsos, Cx. 17, D. 1544; Arquivo Histórico Ultramarino, Administração Central, Conselho Ultramarino, Assento e Fianças dos Contratos Reais, cód. 296; Arquivo Histórico Ultramarino, Administração Central, Conselho Ultramarino, Bahia, Avulsos, Cx. 27 D. 2482 ; Arquivo Histórico Ultramarino, Administração Central, Conselho Ultramarino, Bahia, Avulsos, Cx. 85, D. 6945; Arquivo Histórico Ultramarino, Administração Central, Conselho Ultramarino, Assento e Fianças dos Contratos Reais, cód. 297; Arquivo Histórico Ultramarino, Administração Central, Conselho Ultramarino, Assento e Fianças dos Contratos Reais, cód. 298; Arquivo Histórico do Tribunal de Contas de Portugal, Erário Régio, liv. 4253; Arquivo Histórico Ultramarino, Administração Central, Conselho Ultramarino, Bahia, Avulsos, Cx. 112, D. 8792; Arquivo Histórico Ultramarino, Administração Central, Conselho Ultramarino, Bahia, Castro Almeida, Avulsos, Cx. 57, D. 10961-10962; Arquivo Histórico do Tribunal de Contas de Portugal, Erário Régio, liv. 535. Arquivo Histórico Ultramarino, Administração Central, Conselho Ultramarino, Mapa Cronológico dos Contratos do Ultramar, cód. 1269 e Arquivo Histórico Ultramarino, Administração Central, Conselho Ultramarino, Bahia, 2a série, cx. 33, doc. 3031 apud CARRARA, Ângelo Alves, Receitas e Despesas da Real Fazenda no Brasil: século XVIII, Juiz de Fora: Ed. UFJF, 2009. p. 213.

No gráfico 20, verificamos que a Bahia partiu de um patamar elevado, na casa dos 66 contos, com franca ascendência até a década de 1730, quando atingiu mais de 78 contos. No final desta década assistiu-se o seu encolhimento, seguida de posterior estagnação. Em que pese não possuirmos dados a partir de meados da década de 1780 até a virada do século, notamos que em 1779 se ensaiava uma recuperação, em que os valores de arrematação chegavam bem próximos de seu maior valor alcançado cinquenta anos antes. Em 1804 os valores retornam aos números do período de estagnação, o que contribui para que a linha tendencial esteja em baixa. 
Gráfico 20 - Dízima da Alfândega da Bahia 1720-1807 (em contos de réis)

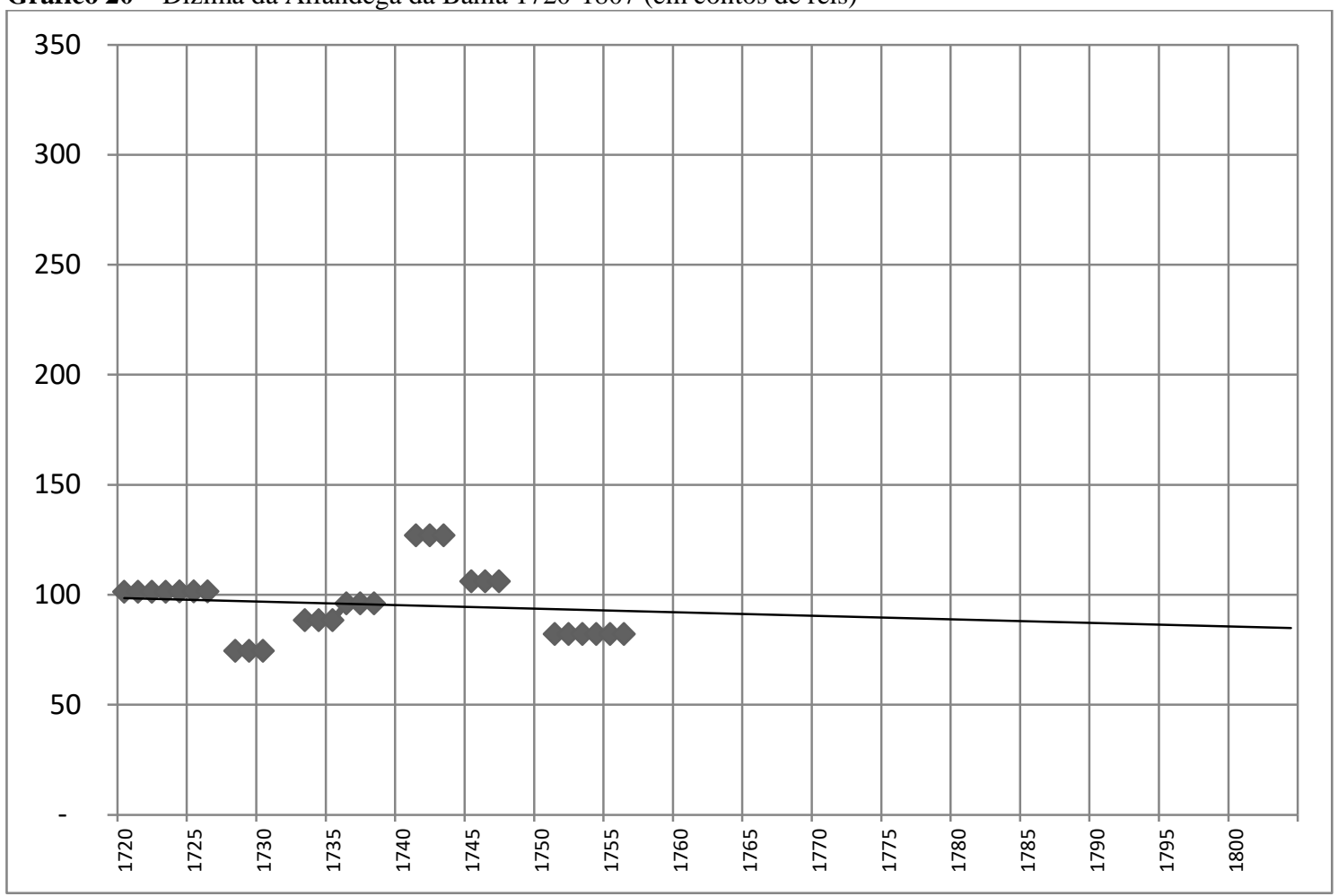

Fontes: PAIVA, A. Banco de Dados dos Contratos do Conselho Ultramarino, 2012; Arquivo Histórico Ultramarino, Administração Central, Conselho Ultramarino, Assento e Fianças dos Contratos Reais, cód. 296; Arquivo Histórico Ultramarino, Administração Central, Conselho Ultramarino, Assento e Fianças dos Contratos Reais, cód. 297; Arquivo Histórico Ultramarino, Administração Central, Conselho Ultramarino, Assento e Fianças dos Contratos Reais, cód. 298.

A dízima da alfândega da Bahia sofre do mesmo problema que os dízimos em relação à coleta de dados. Esta ausência de registros pode ser explicada por conta da organização dos registros das receitas em Contadorias, após a criação do Erário Régio. A Bahia, bem como as capitanias denominadas como "do norte", fazia parte da "Contadoria Geral do Maranhão, Baía e África Ocidental"12, livros que não estão disponíveis no Arquivo Histórico do Tribunal de Contas de Lisboa. Conquanto, estão disponíveis neste arquivo os livros borradores, que contém lançamentos diários/mensais das receitas, o que para nosso objeto não era de tanta valia, já que esses lançamentos em sua maior parte não especificam a quais anos ou arrematações são referentes.

De qualquer forma, podemos observar algumas questões importantes nestes lançamentos. Vale ressaltar que embora o movimento seja bastante irregular, parte-se de um patamar bastante elevado, na casa dos 100 contos e o último dado que dispomos, para 1755, é de mais de 80 contos. Com uma queda logo no início da série, desvalorizando o contrato em $25 \%$, vemos uma recuperação nas arrematações seguintes,

\footnotetext{
${ }^{12}$ MOREIRA, Alzira Teixeira Leite, Inventário do Fundo Geral do Erário... Op. cit., p. XVII.
} 
chegando a mais de 125 contos no triênio 1741-1743. Podemos atribuir algumas dessas variações aos movimentos do preço do açúcar no período, conforme abordado no capítulo anterior (Gráfico 1, 2 e 3). Uma grande variação nos preços da Bahia, que atingiram pico de valorização em 1736 seguido de queda vertiginosa até 1739 podem explicar um pouco desta desvalorização, que também é sentida nos dízimos no período de 1735-1737.

O que se pode afirmar com os dados que dispomos e tomando uma perspectiva mais alargada dos movimentos da primeira metade do século XVIII é que o viés da alfândega da Bahia parece realmente ser de queda. Somem-se as variações do preço do açúcar à consolidação do abastecimento das minas via Rio de Janeiro, o que pode ser comprovado ao menos desde 1728, quando os rendimentos do Caminho Novo superam os do Caminho Velho. ${ }^{13}$

A queda nos preços do açúcar, principal produto de exportação na Bahia, impacta diretamente o movimento dos arrendamentos. No caso das alfândegas, a menor oferta de meio circulante, resultante das transações do açúcar, restringe as mercadorias que dão entrada naquele porto, diminuindo o rendimento deste tributo. Os contratadores, atentos aos movimentos mais gerais da economia, podem perceber estas variações na atividade, o que culmina em uma desvalorização nos lances para a arrematação dos contratos. Não apenas na Bahia isto acontece, mas nas arrematações como um todo. Vale notar que o desempenho positivo do tabaco não compensa, aparentemente, o açúcar.

\footnotetext{
${ }^{13}$ CARRARA, Ângelo, Minas e currais... Op. cit., p. 119.
} 
Gráfico 21 - Índices dos preços do açúcar e importação de escravos em relação aos dízimos da Bahia 1720-1807 $(1762=100)$

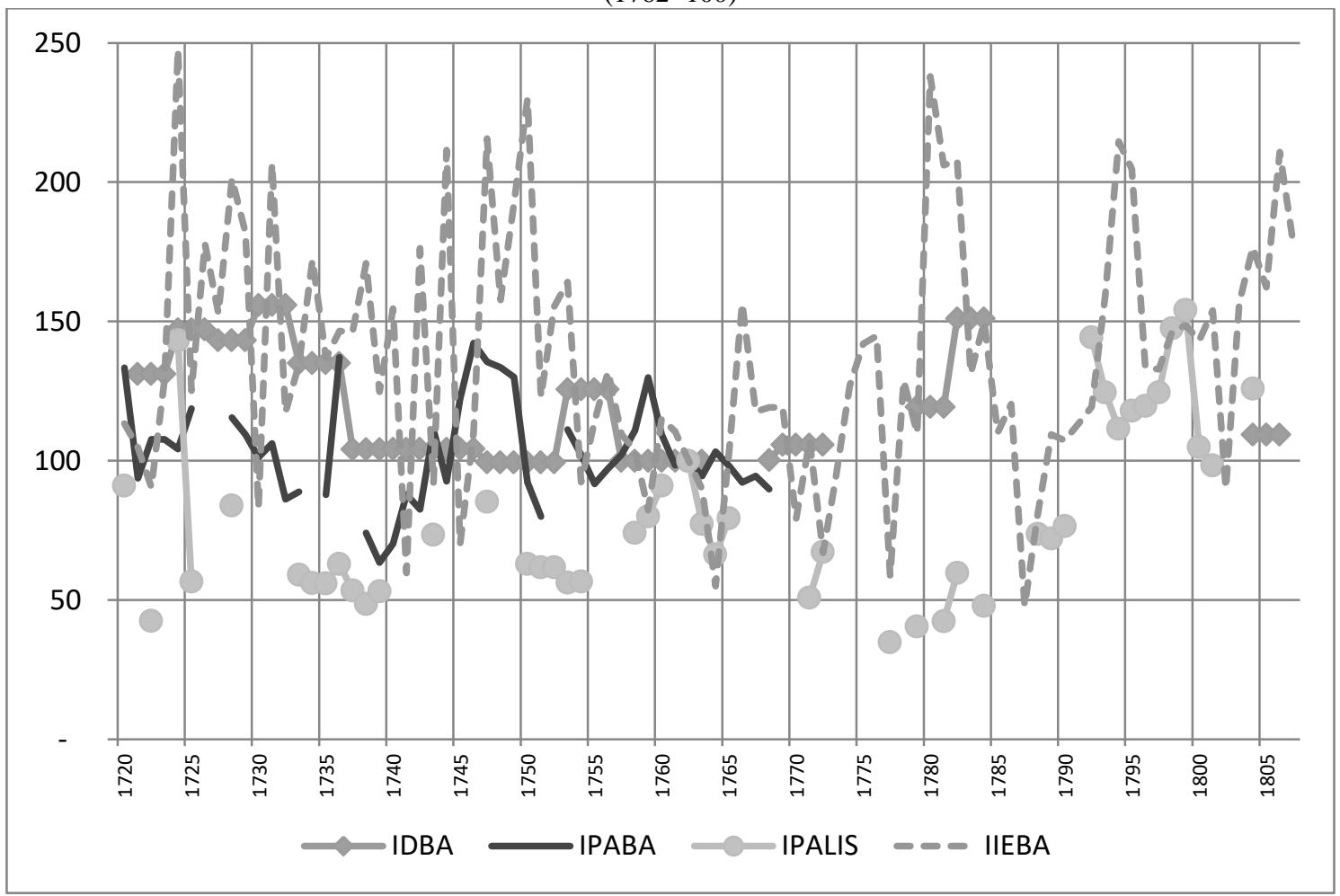

Legendas: IDBA: Índice dos dízimos da Bahia; IPABA: Índice dos preços do açúcar da Bahia; IPALIS: Índice dos preços do açúcar de Lisboa; IIEBA: Índice das importações de escravos da Bahia.

Fontes: PAIVA, A. Banco de Dados dos Contratos do Conselho Ultramarino, 2012; Arquivo Histórico Ultramarino, Administração Central, Conselho Ultramarino, Bahia, Avulsos, Cx. 7, D. 561; Arquivo Histórico Ultramarino, Administração Central, Conselho Ultramarino, Bahia, Avulsos, Cx. 17, D. 1544; Arquivo Histórico Ultramarino, Administração Central, Conselho Ultramarino, Bahia, Avulsos, Cx. 21, D. 1907; Arquivo Histórico Ultramarino, Administração Central, Conselho Ultramarino, Bahia, Avulsos, Cx. 17, D. 1544; Arquivo Histórico Ultramarino, Administração Central, Conselho Ultramarino, Assento e Fianças dos Contratos Reais, cód. 296; Arquivo Histórico Ultramarino, Administração Central, Conselho Ultramarino, Bahia, Avulsos, Cx. 27 D. 2482; Arquivo Histórico Ultramarino, Administração Central, Conselho Ultramarino, Bahia, Avulsos, Cx. 85, D. 6945; Arquivo Histórico Ultramarino, Administração Central, Conselho Ultramarino, Assento e Fianças dos Contratos Reais, cód. 297; Arquivo Histórico Ultramarino, Administração Central, Conselho Ultramarino, Assento e Fianças dos Contratos Reais, cód. 298; Arquivo Histórico do Tribunal de Contas de Portugal, Erário Régio, liv. 4253; Arquivo Histórico Ultramarino, Administração Central, Conselho Ultramarino, Bahia, Avulsos, Cx. 112, D. 8792; Arquivo Histórico Ultramarino, Administração Central, Conselho Ultramarino, Bahia, Castro Almeida, Avulsos, Cx. 57, D. 10961-10962; Arquivo Histórico do Tribunal de Contas de Portugal, Erário Régio, liv. 535. Arquivo Histórico Ultramarino, Administração Central, Conselho Ultramarino, Mapa Cronológico dos Contratos do Ultramar, cód. 1269 e Arquivo Histórico Ultramarino, Administração Central, Conselho Ultramarino, Bahia, $2^{\mathrm{a}}$ série, cx. 33, doc. 3031 apud CARRARA, Ângelo Alves, Receitas e Despesas da Real Fazenda no Brasil: século XVIII, Juiz de Fora: Ed. UFJF, 2009. p. 213; Fontes: PAIVA, A. Banco de Dados dos Contratos do Conselho Ultramarino, 2012; Arquivo Histórico Ultramarino, Administração Central, Conselho Ultramarino, Assento e Fianças dos Contratos Reais, cód. 296; Arquivo Histórico Ultramarino, Administração Central, Conselho Ultramarino, Assento e Fianças dos Contratos Reais, cód. 297; Arquivo Histórico Ultramarino, Administração Central, Conselho Ultramarino, Assento e Fianças dos Contratos Reais, cód. 298; ELTIS, David, et. al. "Voyages: The TransAtlantic Slave Trade Database" (2008), www.slavevoyages.org (consultado em 12/11/2012).

De vez que os dados da dízima estão muito defasados, resta comparar a evolução dos dízimos com os indicadores explorados no capítulo 2. No gráfico 21, podemos observar algumas similaridades nas variações dos índices de preços do açúcar na Bahia e em Lisboa. Interessante perceber que a curva das importações de escravos encontra algumas variações bastante semelhantes, respondendo aos estímulos gerados pelas recuperações e baixas nos preços do negócio sacarino. 
Destacamos, pois, a queda nos preços do açúcar acompanhada pela diminuição das importações de mão de obra nos anos de 1724, assolado por uma rigorosa seca e ainda pragas nas plantações; queda também em 1762, 1792 e 1799. Em 1758 se assiste uma recuperação, ano em que também se valorizou o rendimento do tabaco; bem como 1771 e 1794, em que há uma melhora geral das finanças baianas e no período final, em inícios do século XIX. ${ }^{14}$ Notemos também a relação que os dízimos apresentam com estes mesmos dados. Há queda até o ano de 1737 e a estagnação deste tributo ao longo dos 30 anos seguintes, quando também as variações do preço do açúcar tornavam difícil alguma valorização, ainda mais se considerarmos o contexto geral das potências europeias, com a Guerra dos Sete Anos.

O que podemos perceber ao final do período, com a crescente importação de mão de obra, é uma recuperação da economia de exportação. Essa recuperação do final do século pode estra ligada à maior produção de tabaco, que pode ser cultivados nas terras já cansadas pelas plantações canavieiras. $\mathrm{O}$ alargamento da fronteira agrícola, em busca de terras menos desgastadas, leva a uma maior especialização da economia da capitania, consolidada ao comércio externo. Após o declínio do ouro, a Bahia se beneficia do comércio de abastecimento, desenvolvido nas áreas agrícolas das minas que após 1760 possuem excedentes das produções que se expandiram pela capitania durante todo período do boom aurífero. Retornaremos a este tema adiante.

\section{Pernambuco}

Assim como na Bahia, carecemos de alguns dados para a série de Pernambuco, porém, seu viés, dado o crescimento em fins do século, alavanca a leitura da linha tendencial. É algo que também podemos confirmar ao observar os dados relativos à dízima da alfândega desta capitania. Passado um grande período de estagnação, com movimentos tímidos, na faixa dos 10 aos 20 contos, o crescimento nas arrematações a partir de 1770, ainda mais quando analisamos o penúltimo lançamento a que tivemos acesso, de 1780, chega a quase 30 contos. Em que levemos em conta o período de lacuna, na virada do século, os dízimos chegam a 70 contos, valor nunca antes alcançado e próximo do triplo de seu maior valor aferido, conforme apontado no Gráfico 22.

\footnotetext{
${ }^{14}$ CARRARA, Ângelo, Receitas e Despesas da Real Fazenda no Brasil: século XVIII... Op. cit., p. 79
} 
Um dos impulsos ao valor comercial de Pernambuco pode ser rastreado na qualidade de seu solo para o incremento da produção do algodão. Produto extremamente demandado na fabricação têxtil, esta cultura era incentivada pelo governador de Pernambuco, Luís Diogo Lobo da Silva, que sugeria até a obrigação das lavouras de açúcar de produzir, ao ano, 2 arrobas de algodão, além da exaltação do clima ao bicho-da-seda. ${ }^{15}$ Em que pese toda uma primeira metade do Setecentos em que o desenvolvimento da produção pernambucana não tenha atingido seu auge, estando em patamares de arrematação bem diferentes da Bahia. Após um período de instabilidade até 1729 , a capitania alcança o patamar dos 20 contos anuais e sofre uma drástica queda para 11, em 1741. Seu desenvolvimento parece constante a partir desta década, quando a série varia menos em relação aos valores alcançados nos lanços. Ainda que algumas lacunas existam, principalmente após 1781, a linha de tendência, que foi puxada pela arrematação da virada para o XIX, mas ainda assim estaria ao menos com um viés de alta.

Gráfico 22 - Dízimos de Pernambuco 1720-1807 (em contos de réis)

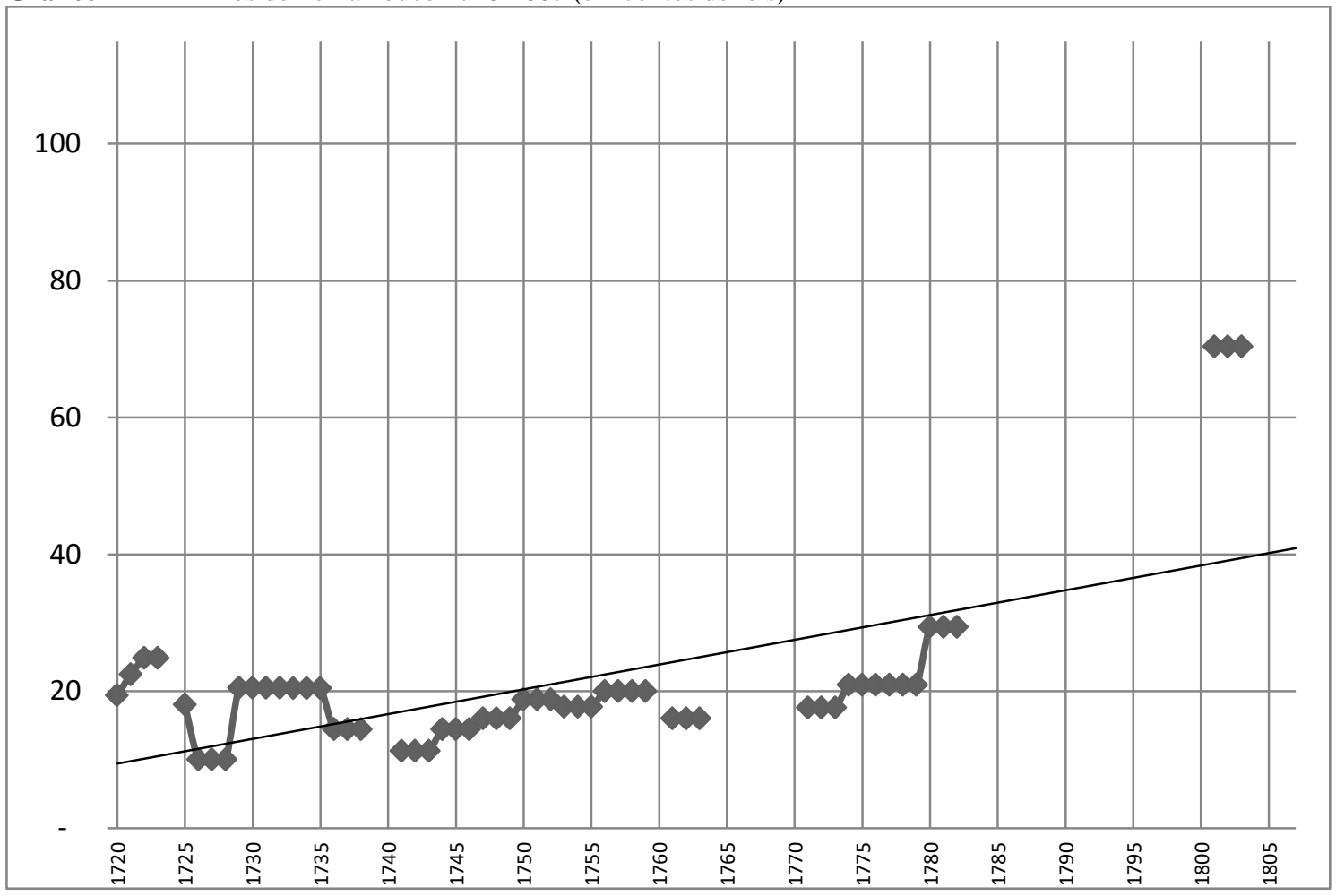

${ }^{15}$ Carta de Luís Diogo a Sebastião José, em 9 de maio de 1757 e 18/05/1767, Arquivo Histórico Ultramarino, Caixas de Pernambuco, caixa 46. Apud RIBEIRO JÚNIOR, José, Colonização e monopólio no Nordeste brasileiro: a Companhia Geral de Pernambuco e Paraíba, 1759-1780.São Paulo: Hucitec, 2004, p. 70. 
Fontes: PAIVA, A. Banco de Dados dos Contratos do Conselho Ultramarino, 2012; Arquivo Histórico Ultramarino, Pernambuco, Avulsos, Administração Central, Conselho Ultramarino, Pernambuco, Avulsos, Cx. 32, D. 2969; Arquivo Histórico Ultramarino, Administração Central, Conselho Ultramarino, Assento e Fianças dos Contratos Reais, cód. 296; Arquivo Histórico Ultramarino, Administração Central, Conselho Ultramarino, Assento e Fianças dos Contratos Reais, cód. 297; Arquivo Histórico Ultramarino, Administração Central, Conselho Ultramarino, Pernambuco, Avulsos, Cx. 56, D. 4876; Arquivo Histórico Ultramarino, Administração Central, Conselho Ultramarino, Assento e Fianças dos Contratos Reais, cód. 298; Arquivo Histórico do Tribunal de Contas de Portugal, Erário Régio, liv. 4253; Arquivo Histórico Ultramarino, Administração Central, Conselho Ultramarino, Pernambuco, Avulsos, Cx. 128, D. 9719; Arquivo Histórico do Tribunal de Contas de Portugal, Erário Régio, liv. 4254. Arquivo Histórico Ultramarino, Administração Central, Conselho Ultramarino, Pernambuco, Avulsos, Carta do provedor da Fazenda Real da capitania de Pernambuco, João do Rego Barros, ao rei D. João V, sobre arrematação do contrato dos dízimos reais da dita capitania; anexo 1 doc.; Recife, 20 de agosto de 1725 [cx. 32, doc. 2952] apud CARRARA, Ângelo Alves, Receitas e Despesas da Real Fazenda no Brasil: século XVIII, Juiz de Fora: Ed. UFJF, 2009. p. 243.

Possuímos algumas lacunas, mas a série das dízimas da alfândega (Gráfico 23) é mais completa tanto em relação aos dízimos desta capitania, quanto aos valores que conseguimos para a Bahia. A linha tendencial é claramente com viés de alta, sustentada por um crescimento que coloca a capitania de Pernambuco em condições de fazer frente à Bahia por volta de 1779. Além disso, consegue disputar com o Rio de Janeiro o posto de maior valor, mas somente quando a Capitania de Minas Gerais já experimentava seu declínio. Ao final do século, Pernambuco chegava ao seu maior rendimento, bastante próximo dos 168 contos de réis.

Um dos "gargalos" que podemos apontar para o caso pernambucano em relação aos valores de arrematação dos contratos está no fato de que em inícios da segunda metade do século XVIII foi instituída uma empresa privilegiada, a Companhia Geral de Pernambuco e Paraíba, que atuou no comércio daquela localidade entre 1759 e 1780. De acordo com registros do governador José César de Menezes, feito nos anos em que a empresa monopolista agonizava, os valores dos contratos da dízima da alfândega de Pernambuco somando os 18 anos anteriores, 1742-1759, caiu de 706 contos para 495 contos nos primeiros 18 anos de seu funcionamento, 1760-1777. ${ }^{16} \mathrm{O}$ movimento da instalação de uma companhia mercantil privilegiada representou uma ação de poder da Coroa, favorecendo os grupos metropolitanos em detrimento dos locais. Ao passo que a empresa estimula a produção colonial de exportação por meio de seus capitais, captura, por sua vez, os rendimentos dos gêneros exportados, mantendo na metrópole os ganhos mais avultados de capital e, com isso, fortalecendo o pacto colonial. ${ }^{17}$

\footnotetext{
${ }^{16}$ Carta de J. César à junta da administração, 13/7/1778. Arquivo Histórico Ultramarino, Caixas de Pernambuco, caixa 66. Apud RIBEIRO JÚNIOR, José, Colonização e monopólio... Op. cit., p. 187-8.

${ }^{17}$ Mesmo com esforços do governador Luis Diogo Lobo da Silva no sentido da defesa dos mercadores locais, a companhia foi criada com os capitais oriundos dos grandes mercadores do Império, como aqueles ligados ao contrato do tabaco, Anselmo José da Cruz, José Rodrigues Bandeira e Ignácio Pedro Quintela. Cf. RIBEIRO JÚNIOR, José, Colonização e monopólio... Op. cit., p. 79-95.
} 
A estratégia do governo Josefino por meio da ação de Pombal foi a de arregimentar os capitais tanto da nobreza quanto de um grupo mercantil formado por essa burguesia comercial que se organizava em torno dos contratos. ${ }^{18}$ Se por um lado a inserção de mercadorias e a organização do comércio de exportação levam a uma multiplicação das produções pernambucanas, por outro apenas com a sua extinção é que as amarras puderam ser desfeitas. No caso do algodão, mesmo com as cartas do governador a companhia não chegou a estimular sobremaneira esta cultura, que atingiu seu auge apenas com a extinção da empresa monopolista. ${ }^{19}$ No entanto, a questão fundamental na valorização e do auge da cotonicultura, sem dúvidas, é o estímulo dado pela Revolução Industrial na Inglaterra, que demanda toneladas desta matéria-prima. Se a valorização do contrato dos dízimos que se dá em 1801 estiver seguindo um desenvolvimento mais firme desde 1780, último lançamento que dispomos, podemos atribuir ao menos parte desta valorização à cultura algodoeira, que possui maior valor em relação à tonelada do que o açúcar. $\mathrm{O}$ aumento substancial a partir de 1782 mostra que de alguma forma o comércio na capitania foi aumentado, gerando rendimentos suficientes para esta variação positiva nos valores da dízima.

Gráfico 23 - Dízima da Alfândega de Pernambuco 1720-1807 (em contos de réis)

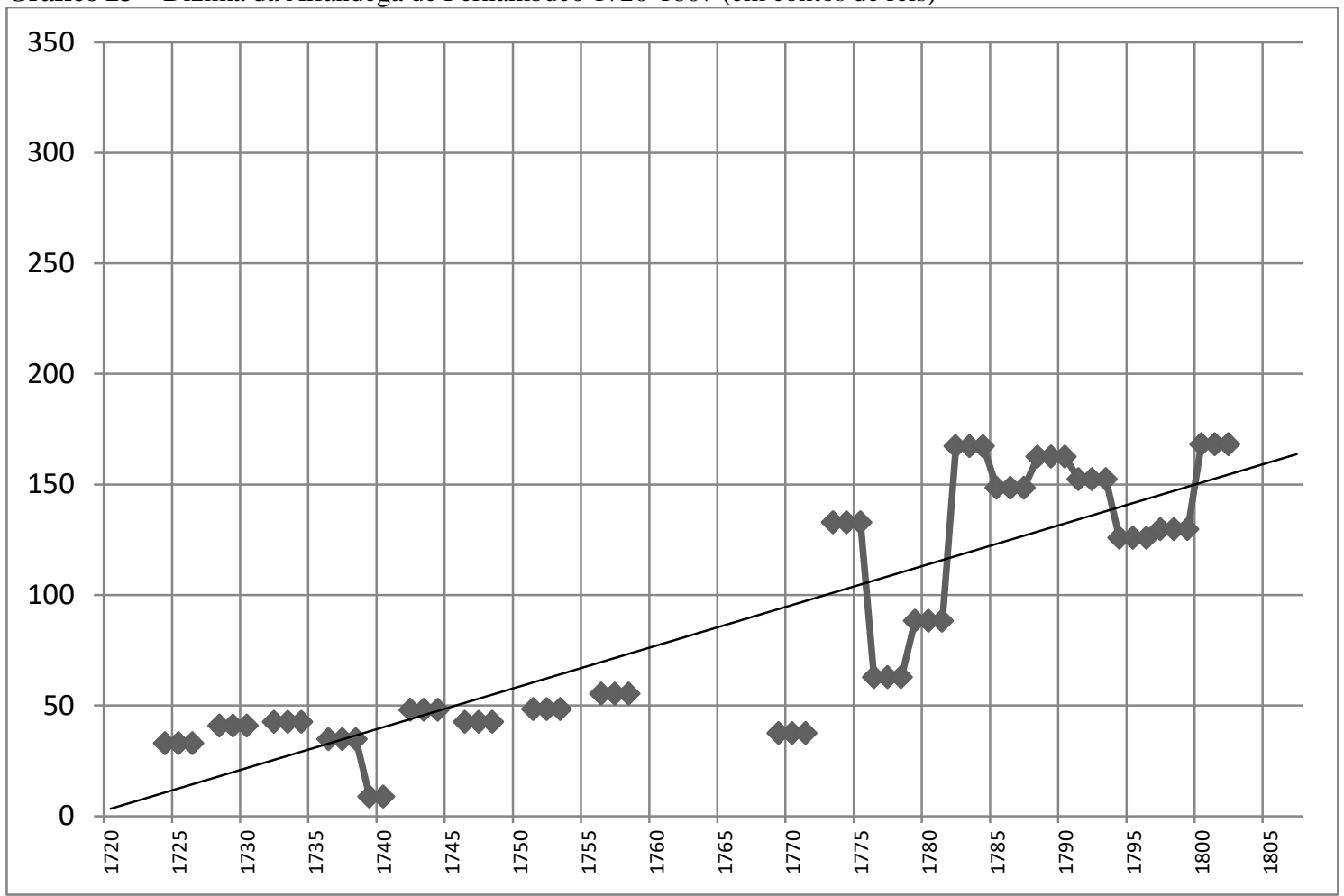

\footnotetext{
${ }^{18}$ RIBEIRO JÚNIOR, José, Colonização e monopólio... Op. cit., p. 98.

${ }^{19}$ Ibibem, p. 107.
} 
Fontes: PAIVA, A. Banco de Dados dos Contratos do Conselho Ultramarino, 2012; Arquivo Histórico Ultramarino, Administração Central, Conselho Ultramarino, Assento e Fianças dos Contratos Reais, cód. 296; Arquivo Histórico Ultramarino, Administração Central, Conselho Ultramarino, Assento e Fianças dos Contratos Reais, cód. 297; Arquivo Histórico Ultramarino, Administração Central, Conselho Ultramarino, Pernambuco, Avulsos, Cx. 79, D. 6544. Biblioteca Nacional do Rio de Janeiro. Divisão de Manuscritos. Relação demonstrativa dos rendimentos da capitania de Pernambuco; 05, 03, 17; coleta feita a partir da folha 14 v.; inclui alguns dados da capitania de Itamaracá; na folha 95 acha-se registrado o "rendimento das sobras das provedorias do Ceará, Paraíba e Rio Grande do Norte". apud CARRARA, Ângelo Alves, Receitas e Despesas da Real Fazenda no Brasil: século XVIII, Juiz de Fora: Ed. UFJF, 2009. p. 255-57.

Pernambuco até inícios do século XVIII parece ter algumas semelhanças ao caso baiano. No caso, pelo fato de possuirmos séries mais sólidas em relação às alfândegas, podemos observar algumas variações que se relacionam com os dízimos e que, por sua vez, respondem a alguns estímulos provocados pela variação dos preços do açúcar em Lisboa. Se não é possível estabelecer uma relação de causalidade entre estes índices, pela própria constituição heterogênea das fontes, podemos ao menos apontar algumas similaridades nos movimentos que compõe este quadro e que sofre bastante com as influências dos eventos externos caros ao negócio do açúcar e que reverberam na demanda efetiva de braços nesta localidade, resultando em um movimento bastante irregular nas importações de escravos.

Gráfico 24 - Índices os preços do açúcar e importação de escravos em relação aos dízimos e alfândegas de Pernambuco 1720-1807 (1762=100)

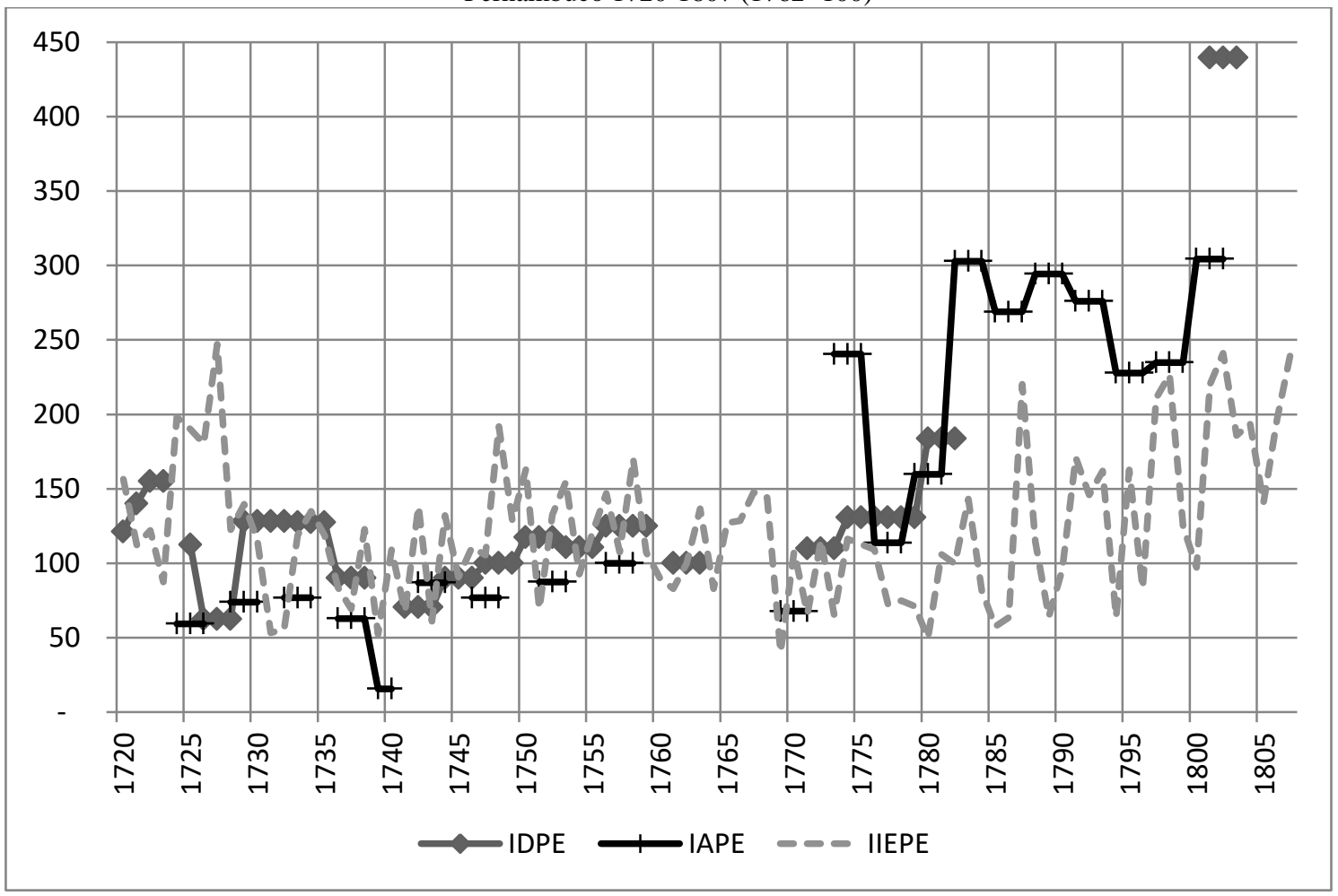

Legenda: IDPE: Índice dos dízimos de Pernambuco; IAPE: Índice das dízimas da alfândega de Pernambuco; IIEPE: Índice da importação de escravos de Pernambuco

Fontes: PAIVA, A. Banco de Dados dos Contratos do Conselho Ultramarino, 2012; Arquivo Histórico Ultramarino, Pernambuco, Avulsos, Administração Central, Conselho Ultramarino, Pernambuco, Avulsos, Cx. 32, D. 2969; Arquivo Histórico Ultramarino, Administração Central, Conselho Ultramarino, Assento e Fianças dos Contratos Reais, cód. 296; Arquivo Histórico Ultramarino, 
Administração Central, Conselho Ultramarino, Assento e Fianças dos Contratos Reais, cód. 297; Arquivo Histórico Ultramarino, Administração Central, Conselho Ultramarino, Pernambuco, Avulsos, Cx. 56, D. 4876; Arquivo Histórico Ultramarino, Administração Central, Conselho Ultramarino, Assento e Fianças dos Contratos Reais, cód. 298; Arquivo Histórico do Tribunal de Contas de Portugal, Erário Régio, liv. 4253; Arquivo Histórico Ultramarino, Administração Central, Conselho Ultramarino, Pernambuco, Avulsos, Cx. 128, D. 9719; Arquivo Histórico do Tribunal de Contas de Portugal, Erário Régio, liv. 4254. Arquivo Histórico Ultramarino, Administração Central, Conselho Ultramarino, Pernambuco, Avulsos, Carta do provedor da Fazenda Real da capitania de Pernambuco, João do Rego Barros, ao rei D. João V, sobre arrematação do contrato dos dízimos reais da dita capitania; anexo 1 doc.; Recife, 20 de agosto de 1725 [cx. 32, doc. 2952] apud CARRARA, Ângelo Alves, Receitas e Despesas da Real Fazenda no Brasil: século XVIII, Juiz de Fora: Ed. UFJF, 2009. p. 243; PAIVA, A. Banco de Dados dos Contratos do Conselho Ultramarino, 2012; Arquivo Histórico Ultramarino, Administração Central, Conselho Ultramarino, Assento e Fianças dos Contratos Reais, cód. 296; Arquivo Histórico Ultramarino, Administração Central, Conselho Ultramarino, Assento e Fianças dos Contratos Reais, cód. 297; Arquivo Histórico Ultramarino, Administração Central, Conselho Ultramarino, Pernambuco, Avulsos, Cx. 79, D. 6544. Biblioteca Nacional do Rio de Janeiro. Divisão de Manuscritos. Relação demonstrativa dos rendimentos da capitania de Pernambuco; 05, 03, 17; coleta feita a partir da folha 14 v.; inclui alguns dados da capitania de Itamaracá; na folha 95 acha-se registrado o "rendimento das sobras das provedorias do Ceará, Paraíba e Rio Grande do Norte". apud CARRARA, Ângelo Alves, Receitas e Despesas da Real Fazenda no Brasil: século XVIII, Juiz de Fora: Ed. UFJF, 2009. p. 255-57; ELTIS, David, et. al. "Voyages: The Trans-Atlantic Slave Trade Database" (2008), www.slavevoyages.org (consultado em 12/11/2012).

Podemos observar no Gráfico 24 similaridades de queda nos anos iniciais, já na década de 1720, e a partir de 1734, seguido de lenta recuperação iniciada em 1740 que se prolonga até o final da década de 1750. A queda de 1775, geral nos demais índices, precede a recuperação que alça a capitania ao ponto de destaque no Nordeste da colônia, ocupando o lugar da Bahia. Uma das hipóteses que pode ser levantada para essa substituição pode estar ligada ao fato novo do incremento da produção algodoeira pernambucana, sobretudo a partir da década de $1790 .{ }^{20} \mathrm{~A}$ demanda mais firme por mão de obra escrava também pode ser um indício do desenvolvimento e consolidação de Pernambuco no mercado de exportação do algodão.

\section{Rio de Janeiro}

Os dízimos do Rio de Janeiro apresentaram um comportamento padrão de crescimento longo e sustentado, passando por momentos de leve estagnação, mas sempre levando a capitania em direção a arrematações mais altas. A partir de 1780, a Capitania do Rio de Janeiro consolida seu crescimento, quebrando a barreira dos 30 contos, experimentando elevações substantivas até 1797, quando dobrou seu valor, passando dos 60 contos. Encerra a série com um aumento substancial de 50\%, chegando a mais de 90 contos na primeira década do século XIX. A linha de tendência mostra como esse crescimento ao longo do tempo se mantém (Gráfico 25).

\footnotetext{
${ }^{20}$ Idem, p. 236.
} 
Gráfico 25 - Dízimos do Rio de Janeiro 1720-1807 (em contos de réis)

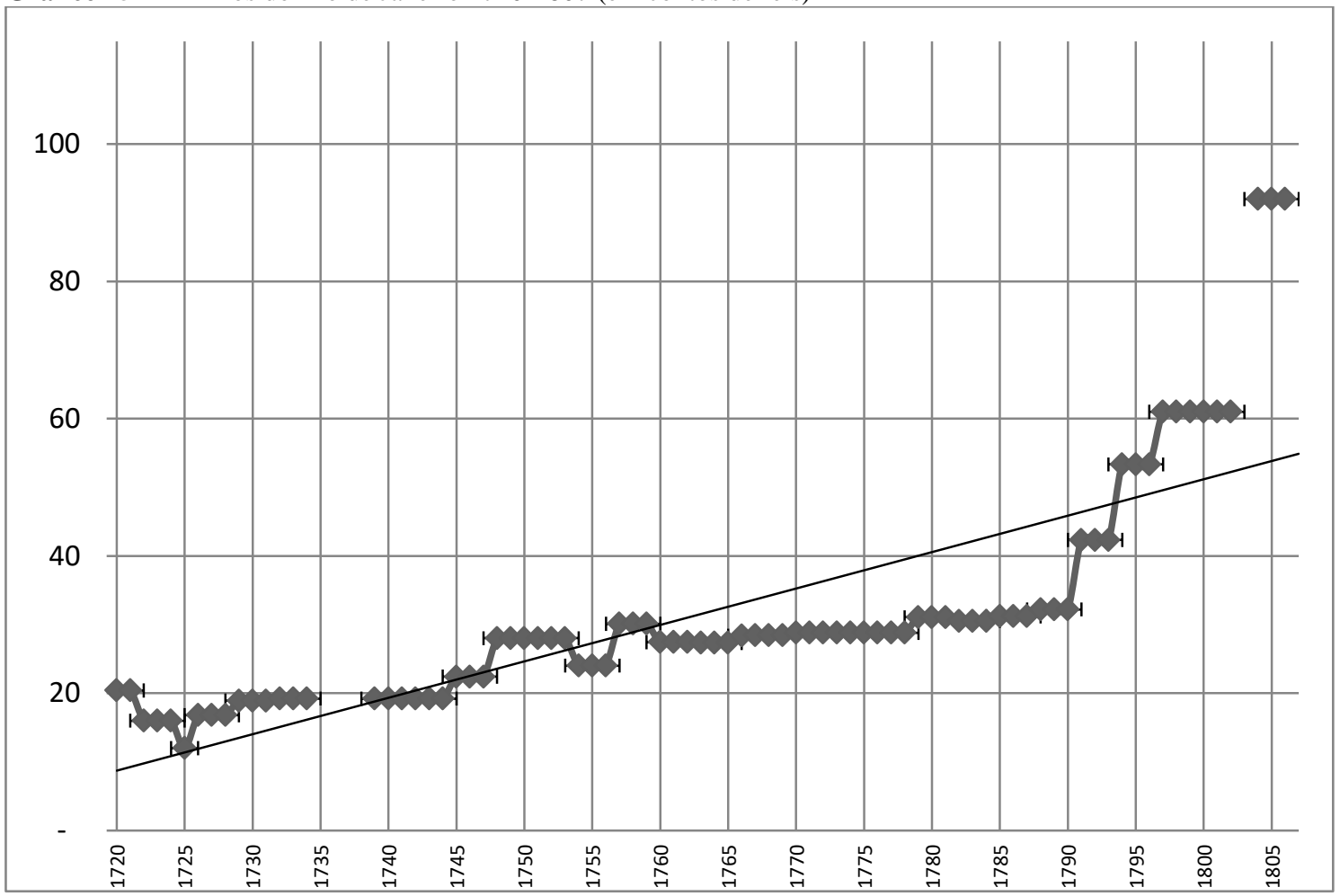

Fontes: PAIVA, A. Banco de Dados dos Contratos do Conselho Ultramarino, 2012; Arquivo Histórico Ultramarino, Administração Central, Conselho Ultramarino, Rio de Janeiro, Avulsos, Cx. 10, D. 1131; Arquivo Histórico Ultramarino, Administração Central, Conselho Ultramarino, Rio de Janeiro, Avulsos, Cx. 12, D. 1355; Arquivo Histórico Ultramarino, Administração Central, Conselho Ultramarino, Rio de Janeiro, Avulsos, Cx. 15, D. 1718; Arquivo Histórico Ultramarino, Administração Central, Conselho Ultramarino, Assento e Fianças dos Contratos Reais, cód. 296; Arquivo Histórico Ultramarino, Administração Central, Conselho Ultramarino, Assento e Fianças dos Contratos Reais, cód. 297; Arquivo Histórico Ultramarino, Administração Central, Conselho Ultramarino, Assento e Fianças dos Contratos Reais, cód. 298; Arquivo Histórico do Tribunal de Contas de Portugal, Erário Régio, liv. 4132; Arquivo Histórico Ultramarino, Administração Central, Conselho Ultramarino, Rio de Janeiro, Avulsos, Cx. 129, D. 10263; Arquivo Histórico do Tribunal de Contas de Portugal, Erário Régio, liv. 4106; Arquivo Histórico Ultramarino, Administração Central, Conselho Ultramarino, Assento e Fianças dos Contratos Reais, cód. 306; Arquivo Histórico Ultramarino, Administração Central, Conselho Ultramarino, Assento e Fianças dos Contratos Reais, cód. 307; Arquivo Histórico do Tribunal de Contas de Portugal, Erário Régio, liv. 535.

Assim como nas demais regiões, o imposto da dízima da alfândega do Rio de Janeiro tem origens na constituição da defesa da capitania, sendo cobrada desde o ano de $1699 .{ }^{21}$ Após um período de franco crescimento, desde o início da série, passando por uma leve turbulência no final da década de 1720, a alfândega do Rio de Janeiro chega à marca de 200 contos de réis em finais da década de 1730 e se mantém neste patamar até 1752, quando há uma lacuna de uma década em nossos números (Gráfico 26). O período subsequente apresenta variações, pois dos dados oriundos dos livros da Contadoria, ou seja, no período pós criação do Erário Régio. Essa flutuação se dá de 1762 até 1791, quando os contratos foram administrados pela Fazenda Real. Estas

\footnotetext{
${ }^{21}$ ARAÚJO, José de Souza Azevedo Pizarro e. Memórias Históricas do Rio de Janeiro e das províncias anexas a jurisdição do vice-rei do Estado do Brasil, dedicadas a El-Rei Nosso Senhor Dom João VI. Rio de Janeiro, Imprensa Régia, 1820. Apud FERNANDES, Valter Lenine. Os contratadores e o contrato da dízima da Alfândega da cidade do Rio de Janeiro (1726-1743). Dissertação de Mestrado apresentada ao Programa de Pós Graduação da Universidade Federal do Estado do Rio de Janeiro, 2010, p. 155.
} 
variações, portanto, são devido ao fluxo de entrada dos rendimentos ao ritmo que a própria Fazenda conseguia cobrar, diferentemente do sistema de arrendamento, quando o valor era definido no momento da arrematação.

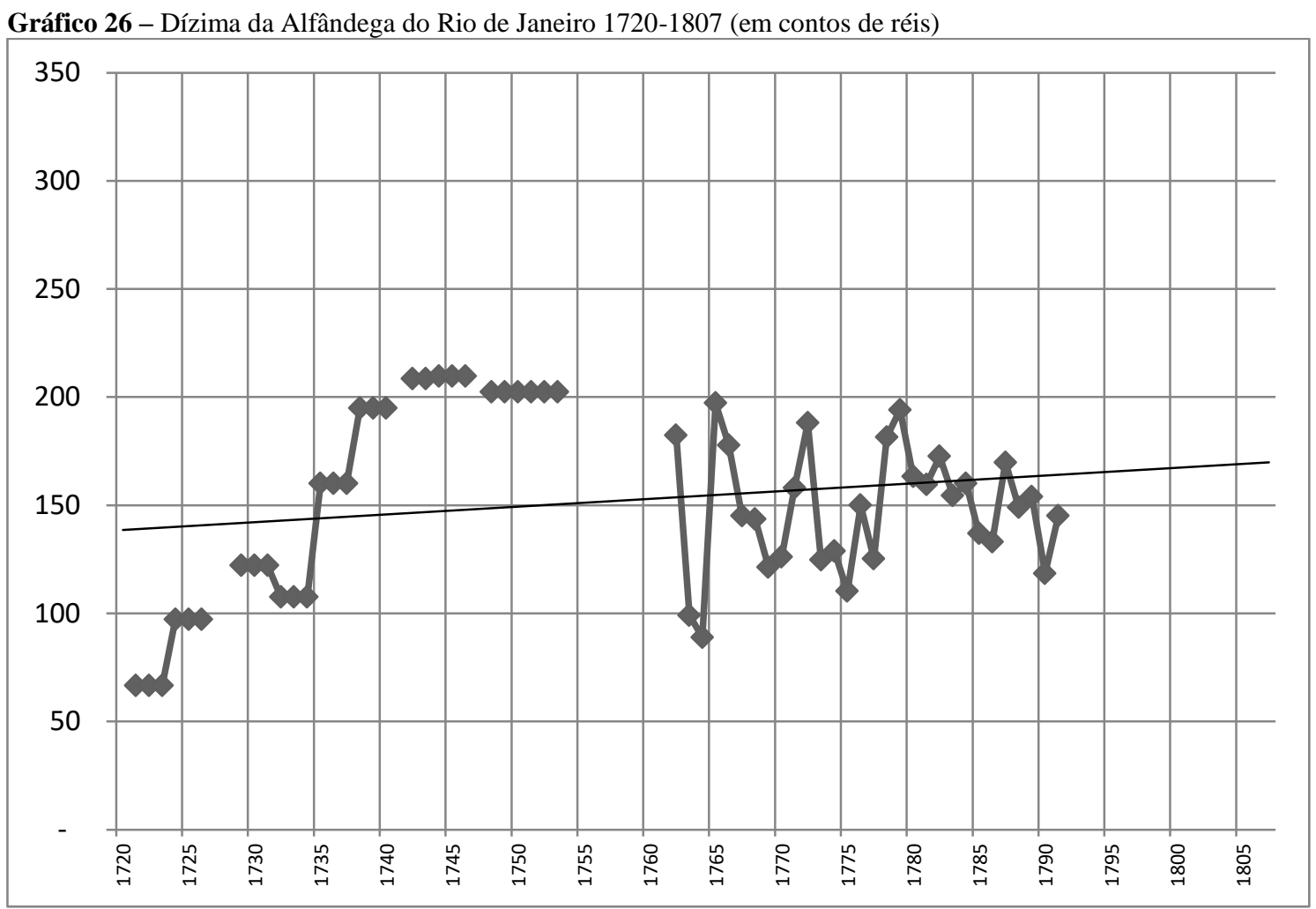

Fontes: PAIVA, A. Banco de Dados dos Contratos do Conselho Ultramarino, 2012; Arquivo Histórico Ultramarino, Administração Central, Conselho Ultramarino, Assento e Fianças dos Contratos Reais, cód. 296; Arquivo Histórico Ultramarino, Administração Central, Conselho Ultramarino, Assento e Fianças dos Contratos Reais, cód. 297; Arquivo Histórico Ultramarino, Administração Central, Conselho Ultramarino, Rio de Janeiro, Avulsos, Cx. 78, D. 7059; Arquivo Histórico do Tribunal de Contas de Portugal, Erário Régio, liv. 4132; Arquivo Histórico do Tribunal de Contas de Portugal, Erário Régio, liv. 4057; Arquivo Histórico do Tribunal de Contas de Portugal, Erário Régio, liv. 4037.

O caso do Rio de Janeiro traz nossa análise para outra atividade de suma importância no século XVIII português. O transporte do ouro, que foi feito substancialmente pelos portos do Rio de Janeiro, impulsionando o crescimento da capitania. $\mathrm{O}$ ano de 1762, inserido no que é conhecido como o período de decadência da extração aurífera, nos força a apresentar este índice em um eixo individual do gráfico, já que a atividade nos anos da primeira metade do XVIII são mais pujantes. Isto posto, podemos perceber com mais clareza que o impulso gerado pela produção do metal amarelo não se esgotou com a diminuição progressiva de seu transporte pelos portos do Rio de Janeiro, a partir da década de 1760, conforme manifesta o Gráfico 27. 
Gráfico 27 - Índices do imposto do $1 \%$ do ouro e importação de escravos em relação aos dízimos e alfândegas do Rio de Janeiro 1720-1807 (1762=100)

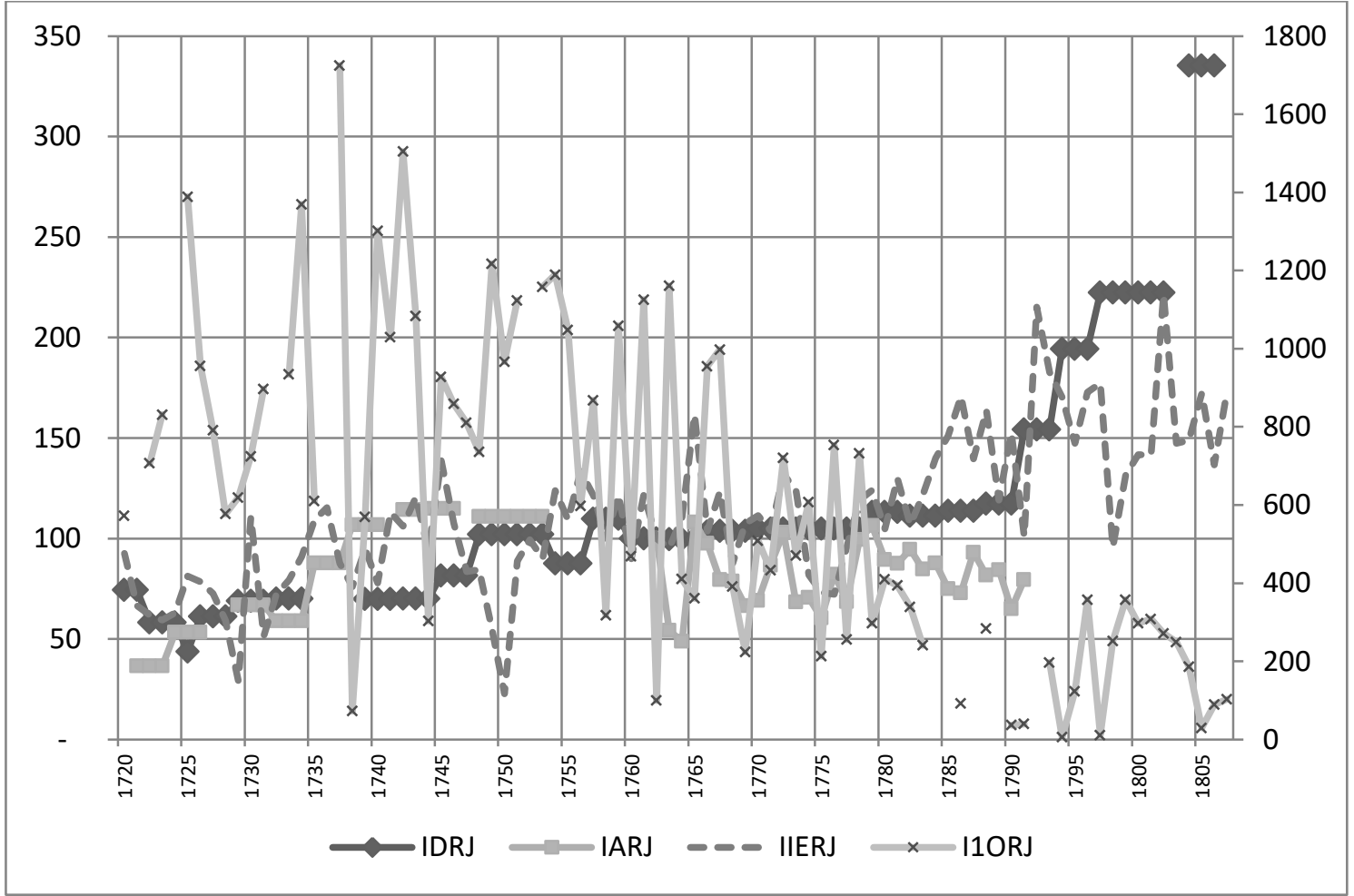

Legenda: IDRJ: Índice dos dízimos do Rio de Janeiro; IARJ: Índice das dízimas da alfândega do Rio de Janeiro; IIERJ: Índice da importação de escravos do Rio de Janeiro; I1ORJ: Índice do imposto do 1\% do ouro transportado pelo Rio de Janeiro.

Fontes: PAIVA, A. Banco de Dados dos Contratos do Conselho Ultramarino, 2012; Arquivo Histórico Ultramarino, Administração Central, Conselho Ultramarino, Rio de Janeiro, Avulsos, Cx. 10, D. 1131; Arquivo Histórico Ultramarino, Administração Central, Conselho Ultramarino, Rio de Janeiro, Avulsos, Cx. 12, D. 1355; Arquivo Histórico Ultramarino, Administração Central, Conselho Ultramarino, Rio de Janeiro, Avulsos, Cx. 15, D. 1718; Arquivo Histórico Ultramarino, Administração Central, Conselho Ultramarino, Assento e Fianças dos Contratos Reais, cód. 296; Arquivo Histórico Ultramarino, Administração Central, Conselho Ultramarino, Assento e Fianças dos Contratos Reais, cód. 297; Arquivo Histórico Ultramarino, Administração Central, Conselho Ultramarino, Assento e Fianças dos Contratos Reais, cód. 298; Arquivo Histórico do Tribunal de Contas de Portugal, Erário Régio, liv. 4132; Arquivo Histórico Ultramarino, Administração Central, Conselho Ultramarino, Rio de Janeiro, Avulsos, Cx. 129, D. 10263; Arquivo Histórico do Tribunal de Contas de Portugal, Erário Régio, liv. 4106; Arquivo Histórico Ultramarino, Administração Central, Conselho Ultramarino, Assento e Fianças dos Contratos Reais, cód. 306; Arquivo Histórico Ultramarino, Administração Central, Conselho Ultramarino, Assento e Fianças dos Contratos Reais, cód. 307; Arquivo Histórico do Tribunal de Contas de Portugal, Erário Régio, liv. 535; PAIVA, A. Banco de Dados dos Contratos do Conselho Ultramarino, 2012; Arquivo Histórico Ultramarino, Administração Central, Conselho Ultramarino, Assento e Fianças dos Contratos Reais, cód. 296; Arquivo Histórico Ultramarino, Administração Central, Conselho Ultramarino, Assento e Fianças dos Contratos Reais, cód. 297; Arquivo Histórico Ultramarino, Administração Central, Conselho Ultramarino, Rio de Janeiro, Avulsos, Cx. 78, D. 7059; Arquivo Histórico do Tribunal de Contas de Portugal, Erário Régio, liv. 4132; Arquivo Histórico do Tribunal de Contas de Portugal, Erário Régio, liv. 4057; Arquivo Histórico do Tribunal de Contas de Portugal, Erário Régio, liv. 4037; ELTIS, David, et. al. "Voyages: The TransAtlantic Slave Trade Database" (2008), www.slavevoyages.org (consultado em 12/11/2012); Gabinete de História Económica e Social - https://aquila4.iseg.ulisboa.pt/aquila/investigacao/ghes/investigacao/projetos-coordenados-pelo-ghes/o-ouro-do-brasil:remessas-e-agentes,-1720-1807 (acesso em 11/07/2016). Apud COSTA, Leonor Freire; ROCHA, Maria Manuela; SOUSA, Rita Martins de. O ouro do Brasil, 1700-1807, Lisboa, Imprensa Nacional - Casa da Moeda, 2013.

A valorização constante dos impostos arrematados e cobrados para o espaço do Rio de Janeiro prosseguiu mesmo com a queda geral dos rendimentos do ouro após 1767. A importação de escravos seguiu caminho interessante. Com a diminuição do afluxo do ouro, estes braços, que em grande quantidade eram repassados às Minas, curiosamente não diminuíram sua entrada pelo Rio de Janeiro. Ao contrário, o índice de entrada dos escravos foi crescente e aumentou até o início da década de 1790, quando sofreu uma queda, recuperando-se e voltando ao mesmo nível já em 1802. O que pode 
explicar esse movimento das importações dos escravos descolado da queda do ouro pode ser o incremento de atividades de abastecimento no Rio de Janeiro e sua própria produção para exportação que começava a tomar fôlego no período, particularmente, o açúcar.

Uma das hipóteses para estes movimentos do Rio de Janeiro está ligada à ideia da passagem desta localidade de mero entreposto das minas para uma economia mais robusta, em que os capitais acumulados nessas operações propiciam um incremento em sua atividade voltada ao mercado interno, mas não só. O que percebemos ao analisar os dados seria uma integração crescente entre as economias denominadas do sul em direção a uma especialização agrária voltada ao abastecimento. Capitaneadas pelo Rio de Janeiro, as economias de São Paulo e Rio Grande de São Pedro do Sul se voltam também ao mercado atlântico, não servindo ao norte do estado do Brasil, mas sim à economia fluminense de exportação que inicia seu desenvolvimento a partir da década de $1770 .^{22}$

O caso do Rio de Janeiro pode exemplificar como os movimentos fiscais - e em alguma medida, da economia - do Atlântico Português, podem se complementar em diversos períodos: na queda dos preços do açúcar, na primeira metade do dezoito, o ouro acabou por compensar em parte as perdas gerais do Império. Do mesmo modo, quando da diminuição do afluxo do metal amarelo se viu uma recuperação das rendas do açúcar - provavelmente mais centrada no Rio de Janeiro, enquanto nas outras capitanias se passa à diversificação (tabaco, algodão) - aproveitando-se, sobretudo, a partir da década de 1790 com a quebra da produção haitiana, provocada pelos conflitos decorrentes de sua independência.

\section{Minas Gerais}

O apogeu e o declínio dos valores de arrematação da capitania de Minas Gerais podem ser explicados pela ação do ouro como multiplicador na economia mineira. Tomando o início de nossa série, os dízimos de Minas Gerais partem dos 40 contos de réis, valor que será multiplicado em mais de duas vezes vinte anos depois, em 1740. Paralelamente, ao observarmos o movimento dos dízimos (Gráfico 28), percebemos que ainda que haja uma queda substancial a partir dos anos 40, os rendimentos seguem em

\footnotetext{
${ }^{22}$ Sobre o crescimento destas regiões, ver Tabelas 9 (Dízimos de São Paulo) e 10 (Dízimos do Rio Grande de São Pedro do Sul) nos Anexos.
} 
um patamar bastante elevado, ficando estagnados a partir de 1768 na casa dos 64 contos.

Os valores que eram aferidos na capitania de Minas Gerais em muito diferiam da maior parte das restantes localidades da América Portuguesa. Mesmo em seus períodos de menor arrecadação, como no início da série, em 1721 o valor do contrato estava na casa dos 20 contos de réis, valor que Pernambuco (Gráfico 22), por exemplo, atingirá com alguma sugestão de consolidação do valor apenas em finais da década de 1770. Isto posto, o desenvolvimento das economias de abastecimento à mineração é fato inevitável. O que pode saltar aos olhos é que mesmo que tenha havido uma grande depreciação nos dízimos, o nível deste ainda parece bastante alto, o que sugere que a produção que era destinada às Minas encontrou novas formas de desenvolvimento e/ou novos mercados.

Gráfico 28 - Dízimos de Minas Gerais 1720-1807 (em contos de réis)

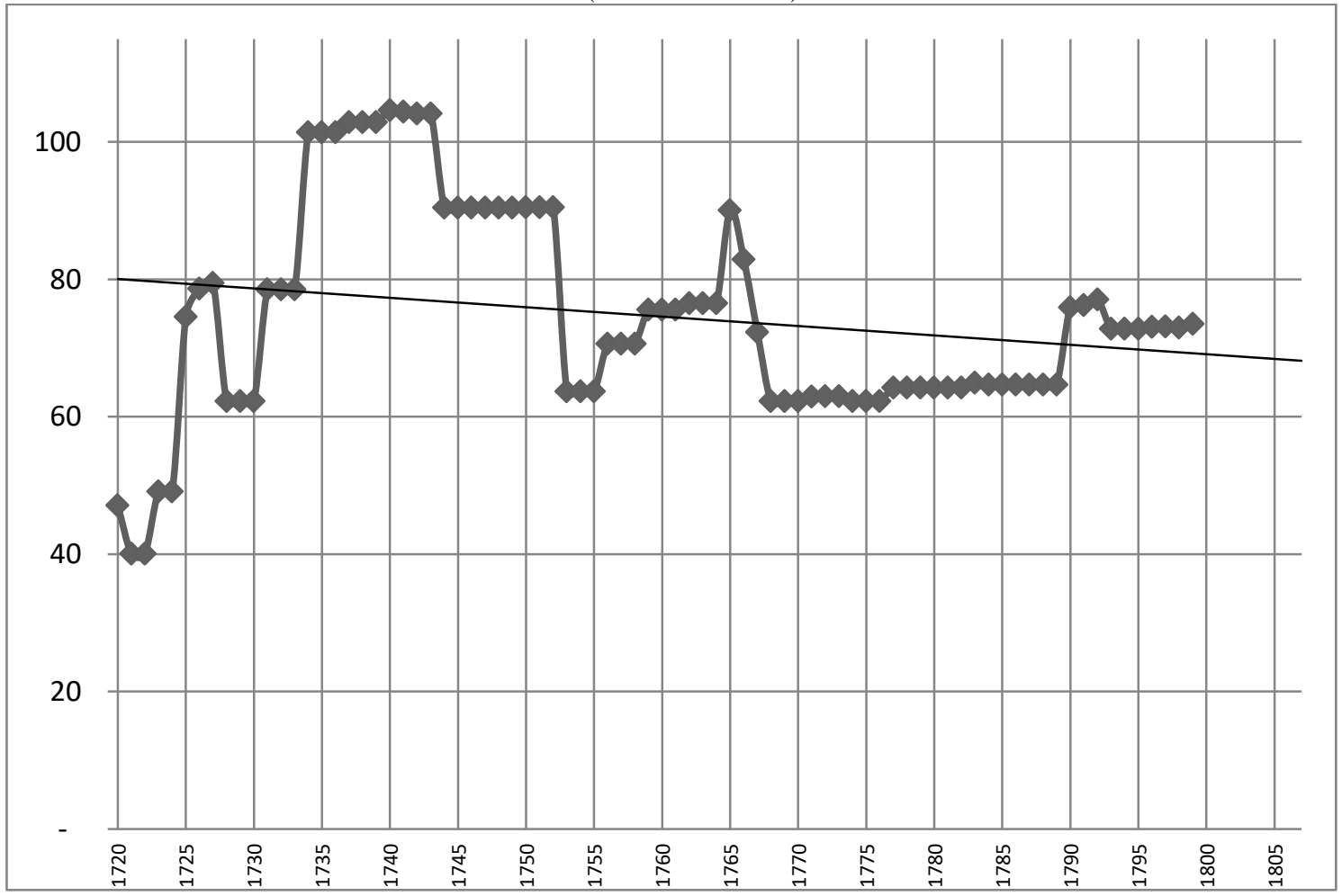

Fontes: PAIVA, A. Banco de Dados dos Contratos do Conselho Ultramarino, 2012; Arquivo Histórico Ultramarino, Administração Central, Conselho Ultramarino, Assento e Fianças dos Contratos Reais, cód. 296; Arquivo Nacional da Torre do Tombo, Manuscritos do Brasil, Contratos do Brasil; Arquivo Histórico Ultramarino, Administração Central, Conselho Ultramarino, Assento e Fianças dos Contratos Reais, cód. 297; Arquivo Histórico Ultramarino, Administração Central, Conselho Ultramarino, Assento e Fianças dos Contratos Reais, cód. 298; Arquivo Histórico do Tribunal de Contas de Portugal, Erário Régio, liv. 4104; Arquivo Histórico do Tribunal de Contas de Portugal, Erário Régio, liv. 4106. Arquivo Público Mineiro. CC 2001: Mapa geral de todo o rendimento de contratos desta capitania de minas gerais, administrados na mesma, e seus pagamentos nesta provedoria desde o $1^{\circ}$ de janeiro de 1722 até o último de dezembro de 1765 , feita a conta pelo valor do ouro ao tempo em que os remates se obrigaram pelas rematações" apud CARRARA, Ângelo Alves, Receitas e Despesas da Real Fazenda no Brasil: século XVIII, Juiz de Fora: Ed. UFJF, 2009. p. 192-93; Biblioteca Nacional (Lisboa), Coleção Pombalina, vol. 643, doc., n²04: "Relação dos rendimentos gerais desta capitania de minas gerais desde os seus descobrimentos conforme a melhor notícia que se tem alcançado e se pôde averiguar nos mesmos rendimentos" apud PINTO, Virgílio Noya, O ouro brasileiro e o comércio anglo-português: uma contribuição aos estudos da economia atlântica no século XVIII, 2 ed., São Paulo: Ed. Nacional, 1979. 
O imposto das entradas de Minas Gerais tem função análoga às alfândegas das capitanias que possuem portos marítimos, ou seja, deve regular a entrada de mercadorias, apresentada no Gráfico 29. Com os ganhos avultados da mineração, percebemos o claro movimento de ascensão e queda da produção aurífera, crescendo a um ritmo bastante alto até 1755 , estagnando-se nesta faixa - movimento que já vinha desde há uma década - dos 230-245 contos até 1763, quando a queda parece irreversível. $^{23}$

Gráfico 29 - Entradas de Minas Gerais 1720-1807 (em contos de réis)

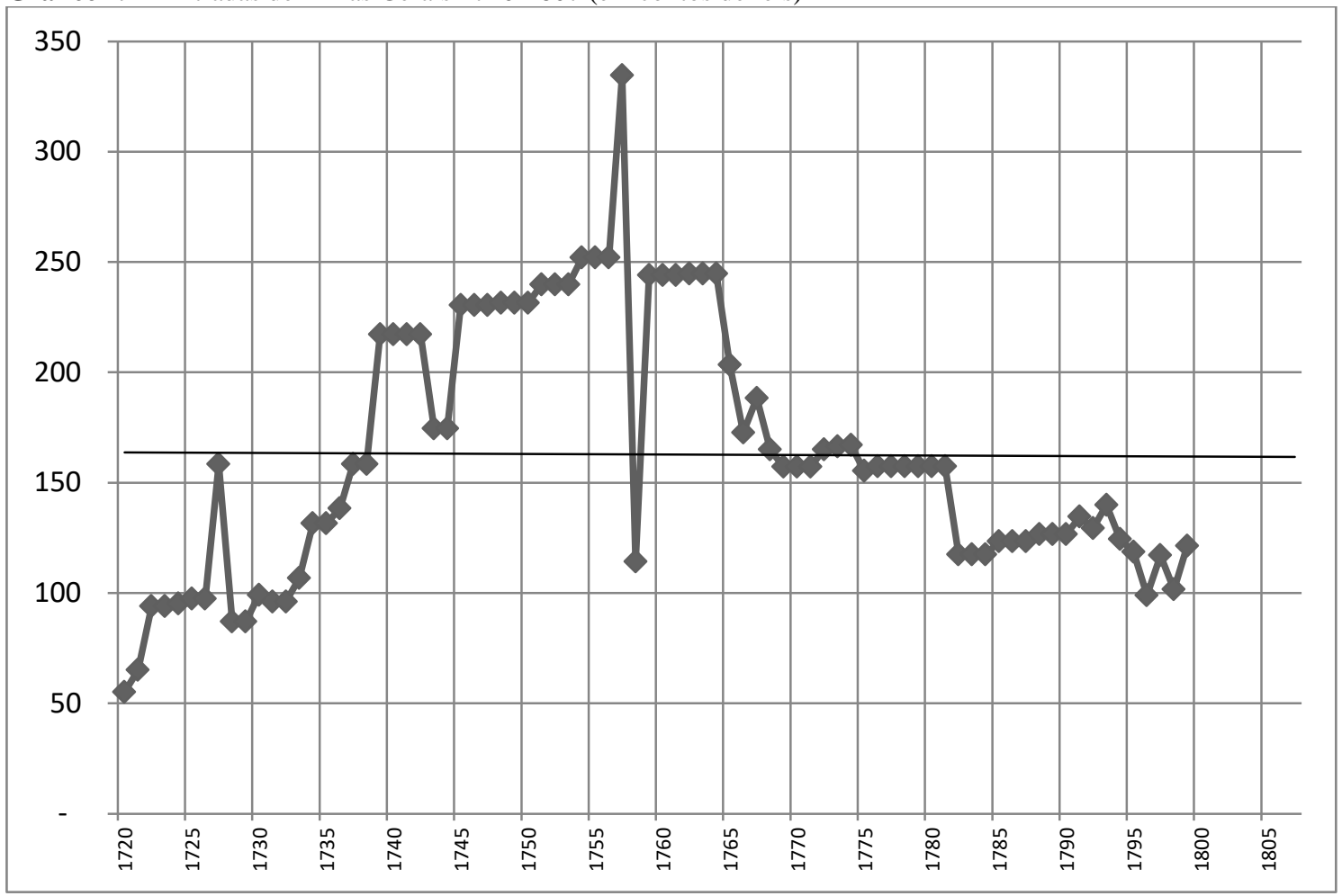

Fontes: PAIVA, A. Banco de Dados dos Contratos do Conselho Ultramarino, 2012; Arquivo Histórico Ultramarino, Administração Central, Conselho Ultramarino, Assento e Fianças dos Contratos Reais, cód. 297; Arquivo Histórico Ultramarino, Administração Central, Conselho Ultramarino, Assento e Fianças dos Contratos Reais, cód. 298; Arquivo Histórico do Tribunal de Contas de Portugal, Erário Régio, liv. 4104; Arquivo Histórico do Tribunal de Contas de Portugal, Erário Régio, liv. 4132; Arquivo Histórico do Tribunal de Contas de Portugal, Erário Régio, liv. 4037; Arquivo Histórico do Tribunal de Contas de Portugal, Erário Régio, liv. 4068. Arquivo Público Mineiro. CC 2001: Mapa geral de todo o rendimento de contratos desta capitania de minas gerais, administrados na mesma, e seus pagamentos nesta provedoria desde o $1^{\circ}$ de janeiro de 1722 até o último de dezembro de 1765 , feita a conta pelo valor do ouro ao tempo em que os remates se obrigaram pelas rematações" apud CARRARA, Ângelo Alves, Receitas e Despesas da Real Fazenda no Brasil: século XVIII, Juiz de Fora: Ed. UFJF, 2009. p. 192-93; Biblioteca Nacional (Lisboa), Coleção Pombalina, vol. 643, doc., n²04: "Relação dos rendimentos gerais desta capitania de minas gerais desde os seus descobrimentos conforme a melhor notícia que se tem alcançado e se pôde averiguar nos mesmos rendimentos" apud PINTO, Virgílio Noya, $O$ ouro brasileiro e o comércio anglo-português: uma contribuição aos estudos da economia atlântica no século XVIII, 2 ed., São Paulo: Ed. Nacional, 1979.

${ }^{23}$ O sobressalto que temos em 1757-1758 é devido ao complemento de nossos dados realizado a partir de outra fonte, obtida em CARRARA, Ângelo, Receitas e Despesas da Real Fazenda no Brasil: século XVIII... Op. cit., p. 192, em que faz uso de fontes compiladas junto ao Arquivo Público Mineiro. 
O gráfico 30, nos mostra o índice geral do $1 \%$ do ouro, escoado por todos os portos da América Portuguesa, mas cuja extração provinha das Minas. Assim como a apresentação deste dado para o Rio de Janeiro foi feita em um eixo secundário, aqui seguimos a mesma metodologia, para que as curvas sejam mais comparáveis visualmente. Para facilitar a visualização foi inserida uma linha de tendência ${ }^{24}$, para que os movimentos sejam mais bem percebidos, já que as grandes variações se dão devido ao regime de frotas, pois o imposto era cobrado somente quando o ouro chegava a Lisboa.

Gráfico 30 - Índices do imposto do $1 \%$ do ouro em relação aos dízimos e entradas de Minas Gerais 1720-1807 $(1762=100)$

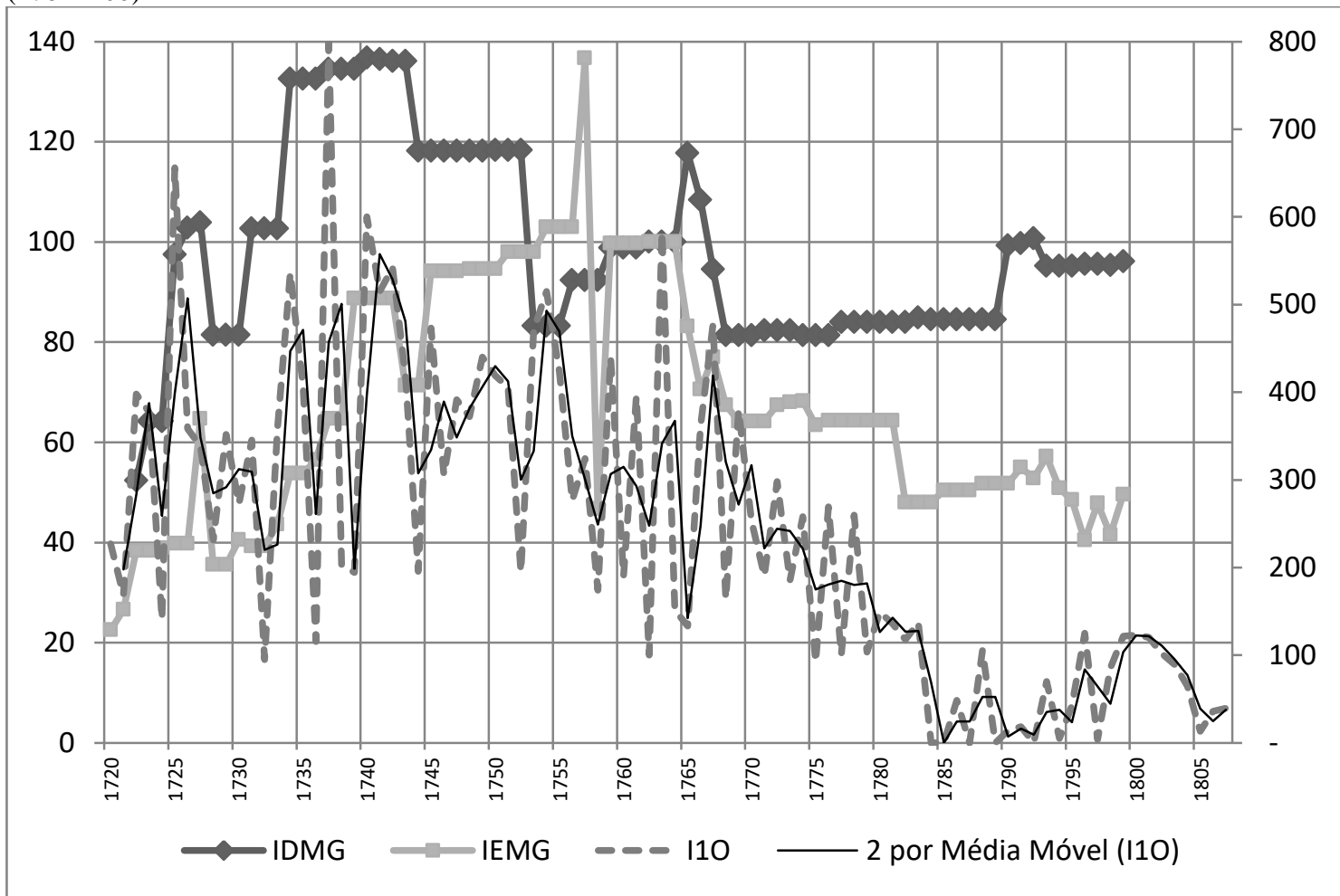

Fontes: PAIVA, A. Banco de Dados dos Contratos do Conselho Ultramarino, 2012; Arquivo Histórico Ultramarino, Administração Central, Conselho Ultramarino, Assento e Fianças dos Contratos Reais, cód. 296; Arquivo Nacional da Torre do Tombo, Manuscritos do Brasil, Contratos do Brasil; Arquivo Histórico Ultramarino, Administração Central, Conselho Ultramarino, Assento e Fianças dos Contratos Reais, cód. 297; Arquivo Histórico Ultramarino, Administração Central, Conselho Ultramarino, Assento e Fianças dos Contratos Reais, cód. 298; Arquivo Histórico do Tribunal de Contas de Portugal, Erário Régio, liv. 4104; Arquivo Histórico do Tribunal de Contas de Portugal, Erário Régio, liv. 4106. Arquivo Público Mineiro. CC 2001: Mapa geral de todo o rendimento de contratos desta capitania de minas gerais, administrados na mesma, e seus pagamentos nesta provedoria desde o $1^{\circ}$ de janeiro de 1722 até o último de dezembro de 1765 , feita a conta pelo valor do ouro ao tempo em que os remates se obrigaram pelas rematações" apud CARRARA, Ângelo Alves, Receitas e Despesas da Real Fazenda no Brasil: século XVIII, Juiz de Fora: Ed. UFJF, 2009. p. 192-93; Biblioteca Nacional (Lisboa), Coleção Pombalina, vol. 643, doc., n²04: "Relação dos rendimentos gerais desta capitania de minas gerais desde os seus descobrimentos conforme a melhor notícia que se tem alcançado e se pôde averiguar nos mesmos rendimentos" apud PINTO, Virgílio Noya, O ouro brasileiro e o comércio anglo-português: uma contribuição aos estudos da economia atlântica no século XVIII, 2 ed., São Paulo: Ed. Nacional, 1979; Fontes: PAIVA, A. Banco de Dados dos Contratos do Conselho Ultramarino, 2012; Arquivo Histórico Ultramarino, Administração Central, Conselho Ultramarino, Assento e Fianças dos Contratos Reais, cód. 297; Arquivo Histórico Ultramarino, Administração Central, Conselho Ultramarino, Assento e Fianças dos Contratos Reais, cód. 298; Arquivo Histórico do Tribunal de Contas de Portugal, Erário Régio, liv. 4104; Arquivo Histórico do Tribunal de Contas de Portugal, Erário Régio, liv. 4132; Arquivo Histórico do Tribunal de Contas de Portugal, Erário Régio, liv. 4037; Arquivo Histórico do Tribunal de Contas de Portugal, Erário Régio, liv. 4068. Arquivo Público Mineiro. CC 2001:

${ }^{24}$ Em médias móveis=2 
Mapa geral de todo o rendimento de contratos desta capitania de minas gerais, administrados na mesma, e seus pagamentos nesta provedoria desde o $1^{\circ}$ de janeiro de 1722 até o último de dezembro de 1765 , feita a conta pelo valor do ouro ao tempo em que os remates se obrigaram pelas rematações" apud CARRARA, Ângelo Alves, Receitas e Despesas da Real Fazenda no Brasil: século XVIII, Juiz de Fora: Ed. UFJF, 2009. p. 192-93; Biblioteca Nacional (Lisboa), Coleção Pombalina, vol. 643, doc., n²04: "Relação dos rendimentos gerais desta capitania de minas gerais desde os seus descobrimentos conforme a melhor notícia que se tem alcançado e se pôde averiguar nos mesmos rendimentos" apud PINTO, Virgílio Noya, O ouro brasileiro e o comércio angloportuguês: uma contribuição aos estudos da economia atlântica no século XVIII, 2 ed., São Paulo: Ed. Nacional, 1979; Gabinete de História Económica e Social - https://aquila4.iseg.ulisboa.pt/aquila/investigacao/ghes/investigacao/projetos-coordenados-peloghes/o-ouro-do-brasil:-remessas-e-agentes,-1720-1807 (acesso em 11/07/2016). Apud COSTA, Leonor Freire; ROCHA, Maria Manuela; SOUSA, Rita Martins de. O ouro do Brasil, 1700-1807, Lisboa, Imprensa Nacional - Casa da Moeda, 2013.

Dito isto, o que pode ser percebida é a movimentação semelhante nas linhas das alfândegas e dos dízimos. Estes anteciparam os movimentos daquela, criando um desenho progressivo em degraus até 1743, quando os dízimos começam sua queda, que foi sentida apenas em 1757 no rendimento das entradas. Porém, seguindo a tendência anunciada nos rendimentos do $1 \%$, desde ao menos 1754 há uma tendência negativa que segue o movimento geral do ouro, na década de 1760.

Não obstante, houve queda de 1/3 nos dízimos, no período de 1765 a 1768, quando o rendimento nunca chegou aos 60 contos de réis, patamar que o Rio de Janeiro só alcançaria em finais do XVIII, em 1797. Em relação às entradas, segue-se modelo parecido ao das demais capitanias mesmo no período de queda, com o rendimento dos dízimos girando em torno de $30 \%$ das entradas/alfândegas. O que é possível observar desde o primeiro olhar para o gráfico 30 é que a curva das Entradas cai em ritmo semelhante ao do imposto do $1 \%$ do ouro. Desta forma, podemos aventar uma hipótese de que a extração aurífera e, no caso, o fato de que o resultado de sua produção pode funcionar como expressão real de valor, quando dos primeiros indícios de sua queda já impacta diretamente nos ânimos dos arrematadores de contratos, que percebem este movimento e passam a oferecer menores lances pelos direitos de arrecadação do tributo. O cerceamento do meio circulante e a sensação de que a declínio das lavras não se reverterá pode ter de certa forma reconduzido os capitais para outras atividades que oferecessem maior segurança, ainda que relativa. ${ }^{25}$

Assim sendo, semelhante ao que se passou no Rio de Janeiro, a mineração traz a pujança e o motor que apenas o ouro pode proporcionar. Não obstante, o esgotamento das lavras, não representou o fim da vida econômica da capitania, que se voltou para novos espaços produtivos e passou a se articular às outras partes do Estado do Brasil por meio da agropecuária. A transição açucareira do Rio de Janeiro utilizando terras de

\footnotetext{
${ }^{25}$ CARRARA, Ângelo Alves, Minas e Currais...Op.cit, p. 288
} 
agricultura de abastecimento, menos cansadas, corresponde à diversificação de Pernambuco e Bahia.

Ao final deste capítulo, relacionamos as rendas aferidas nas partes mais destacadas da América Lusa e levantamos algumas questões acerca dos ritmos da economia colonial. O que em um primeiro momento parecia sugerir a existência de uma mudança completa do eixo de produção e riqueza em que a mineração atuou como força gravitacional das atividades e que com seu colapso as economias de sua sustentação desmoronariam, ao menos de acordo com nossos dados, não se provou verdade. $\mathrm{O}$ desenvolvimento contínuo da capitania do Rio de Janeiro - que, de início, parecia se aproveitar da atividade do transporte do ouro das minas e que depois se volta ao mercado atlântico do açúcar - sugere capitais acumulados na atividade de sustentação das Minas. Entretanto, quando esta passa a sofrer com o declínio das lavras, a economia fluminense continua seu curso de desenvolvimento, não mais como abastecedora, mas legando a outras regiões esta função (Gráficos 27, 30 e Anexos, Tabelas 9 e 10). A própria agropecuária mineira, em vez de servir apenas à mineração passa a atuar em outras funções do abastecimento interno, contribuindo ao desenvolvimento do Rio de Janeiro e seus novos papéis, inclusive o de capital do Estado do Brasil.

Na parte norte, o que podemos destacar, sem dúvidas, é o desenvolvimento de Pernambuco a partir do terceiro quartel do século XVIII, em que se insere no mercado algodoeiro, sem renuncias ao negócio sacarino, estimulado pela Companhia Geral de Pernambuco e Paraíba, que também estimulou a multiplicação de suas produções. Mesmo partindo de um baixo patamar em relação aos dízimos (Gráfico 22), a apreciação do contrato da dízima da alfândega (Gráfico 23) nos aporta indícios de que as atividades produtivas e/ou comerciais sofreram incremento ao longo do século.

O caso da Bahia, por conta das limitações dos dados, é o que menos podemos formular hipóteses baseadas na investigação empírica, porém, ainda alguns exercícios de análise são passiveis de serem feitos. O que os dados relativos à Bahia demonstram é uma estagnação com razoável tendência de queda, ainda que, ressalte-se, permaneça em níveis bastante altos. Os dízimos da capitania, expostos no Gráfico 19, tem um movimento de desvalorização, se considerarmos o recorte como um todo, com uma 
recuperação na década de 1780. Não pudemos aferir se resultou em uma consolidação neste patamar ou se regrediu, o que se observa no início do Oitocentos, quando volta aos 55 contos. Para a dízima da alfândega, Gráfico 20, a análise se mostra ainda mais tímida, porém o aumento que percebemos nas entradas de escravos pode indicar que o nível de renda tenha crescido ao menos o suficiente para que este aporte de mão de obra se sustentasse, ainda mais levando em conta a apreciação do açúcar. Contudo, uma parte desses escravos é reexportada para a Amazônia, economia não analisada neste trabalho, mas em plena expansão. ${ }^{26}$

Assim, não é possível afirmar que o relativo declínio da capitania da Bahia tenha se dado por conta da mudança da capital para o Rio de Janeiro, assim como esta explicação sozinha não dá conta das mudanças de patamar desta economia. O que se assiste durante o século XVIII é uma mudança do eixo econômico da colônia que se dá por conta da mineração, que integra regiões para servir ao seu abastecimento. Neste jogo, tanto regiões pouco desenvolvidas da própria capitania quanto o alargamento das fronteiras para o abastecimento vão em direção ao sul. A questão geográfica e a instituição do Caminho Novo fazem com que o Rio de Janeiro se beneficie dessa renda oriunda da mineração, o que podemos rastrear pela valorização do contrato da dízima da alfândega (Gráfico 26). Mesmo quando este tributo passa a ser administrado pela Fazenda, o rendimento fica na média dos 150 contos de réis. Para a Bahia e Pernambuco, a primeira parece retomar lugar de destaque no comércio mundial do açúcar, após a recuperação dos preços de 1780, conforme abordamos no capítulo 2, década em que também tem um incremento nas suas importações de escravos (Gráfico 17). Pernambuco, em período pouco posterior, se insere no mercado mundial do algodão.

\footnotetext{
${ }^{26}$ Cf. CHAMBOULEYRON, Rafael. Escravos do Atlântico Equatorial: tráfico negreiro para o Estado do Maranhão e Pará (século XVII e início do século XVIII). In: Revista Brasileira de História. São Paulo, v.26, $\mathrm{n}^{\circ}$ 52, 2006. (p. 79-114); DOMINGUES, Daniel. The Atlantic Slave to Maranhão, 1680-1846. Volume, Routes and Organization. Slavery and Abolition, 29:4, p. 477-501; SANTOS, Diego Pereira. Entre Costas Brasílicas: O tráfico interno de escravos em direitura à Amazônia, c.1778-c.1830. Dissertação de Mestrado apresentada ao Programa de Pós-Graduação em História do Instituto de Filosofia e Ciências Humanas da Universidade Federal do Pará. 2013, p. 38, 42-3 et seq.
} 


\section{Considerações Finais}

Chegamos ao final desta empreitada tendo percorrido os meandros da organização das finanças Imperiais portuguesas e suas estratégias de apreensão das rendas produzidas na colônia por meio da fiscalidade. $\mathrm{O}$ que parece claro é que se as remessas de rendimentos podem não ter sido tão avultadas em alguns períodos, ao menos o dispêndio de recursos do Reino para a manutenção das estruturas na América Lusa indica ter sido bastante reduzido e os custos da empreitada colonizadora foram ordinariamente bancados pelas populações locais.

Deste modo, podemos destacar como basilares para a consolidação deste sistema três aspectos: os monopólios, os privilégios e o exclusivo colonial. A escolha pelo arrendamento de contratos para administrar os impostos, aparece como uma das tecnologias do poder que fez com que a Metrópole chegasse ao seu propósito: a extração de rendas da colônia. No Império Português, o fortalecimento das arrecadações utilizando os contratadores, especialmente durante o século XVIII, como braços alargadores do controle estatal caminhava no sentido da aproximação da Coroa aos vassalos, sobretudo aqueles do Reino, criando uma classe de mercadores/negociantes que se enriqueciam e trabalhavam ao encontro da consolidação da hegemonia do Estado. Selava-se assim uma espécie de pacto entre o Estado e o capital mercantil que garantia a transferência de renda da colônia para a metrópole.

Não obstante, a extração aurífera em larga escala altera as relações entre a colônia e o Reino. Ao mesmo tempo em que as regiões ligadas ao ouro demandavam novos produtos da metrópole e de outras regiões europeias, os ganhos no sertão mineiro compensavam as perdas do conjunto do Império no comércio oriental e no negócio do açúcar.

Por outra parte, elementos interessantes podem ser aportados da análise dos preços dos gêneros coloniais, do tráfico de escravos e das séries de impostos arrematados. Os baixos preços do açúcar ajudam a entender a relativa estagnação da agricultura das capitanias do norte. A mudança do centro gravitacional da América portuguesa, produzida pelo advento da mineração, atrai mercadorias e investimentos para o sul, porém a mudança apenas se consolida no período de decadência da extração 
aurífera como se depreende da comparação dos dízimos da Bahia com os do Rio de Janeiro e da alteração da participação nas importações gerais de escravos. O que nos leva a crer que o desenvolvimento proporcionado por esta atividade alçou o Rio de Janeiro à constituição de uma agricultura voltada ao abastecimento das Minas e apenas mais tarde a sua integração ao mercado de exportação. O primeiro fenômeno é fácil de explicar: a expansão demográfica para o sul gerava demandas para a produção de alimentos, favorecendo a hinterland do Rio de Janeiro.

Entretanto, no final do século XVIII, a queda na produção aurífera e a recuperação dos preços do açúcar não diminuíram a proeminência do Rio de Janeiro, o crescimento econômico que se observa no norte deve-se principalmente ao desenvolvimento da cotonicultura no Pernambuco e, em menor medida, ao tabaco da Bahia. O Rio de Janeiro ascendeu em grande parte porque o crescimento da Bahia e de Pernambuco se deu principalmente pela alteração das exportações das capitanias do norte e, consequentemente, da fronteira agrícola dessas regiões. Estas mudanças na estrutura produtiva denotam um certo grau de escolha dos agentes coloniais, ainda que não alterem o enquadramento do Estado do Brasil na divisão mundial do trabalho que se consolidou na época moderna, como já apontado por Celso Furtado.

Por outro lado, a valorização crescente da economia fluminense por meio do açúcar representou uma resposta dos agentes locais à valorização do produto e à estagnação da Bahia e Pernambuco, o que nos leva a perguntar as razões desses movimentos relativamente divergentes. Uma primeira hipótese é que o norte do Estado do Brasil era castigado periodicamente por secas severas ou chuvas em demasia, enquanto que o espaço aberto ao sul era de grande potencial, já que esta região sofreria menos com estes ciclos climáticos, podendo gozar de maior previsibilidade e planejamento das produções, tanto voltadas ao comércio de exportação, quanto à agropecuária voltada ao abastecimento interno. Outra hipótese é que o esgotamento das terras aptas à produção açucareira ao norte teria levado à conversão da produção agrícola para o tabaco e para o algodão. No primeiro caso com rendimentos relativamente mais baixos em relação ao açúcar, no segundo caso, com ganhos auspiciosos o que ajudaria a explicar o desempenho divergente entre Bahia e Pernambuco no final do dezoito. Vale dizer, que esse movimento não impede um 
crescimento conjunto da produção açucareira nas três capitanias entre 1790 e 1811 graças à conjuntura externa extremamente favorável.

A ideia da derrocada total da capitania de Minas parece não fazer muito sentido aos olhos da fiscalidade. Como assinalado por Ângelo Carrara, ainda que, sem dúvidas, esta região tenha sofrido grandes perdas com o fim da mineração, o que parece mais acertado é que o estimulo gerado pelo ouro estimulou algumas regiões para o abastecimento e que mais tarde se voltaram a outros mercados. A explicação está na sustentação da economia fluminense que ganha destaque justamente no declínio do ouro. Não parece descabido assinalar alguns pontos de especialização na economia colonial, como o incremento do mercado interno de alimentos localizado na parte meridional, apoiando a economia do Rio de Janeiro.

Ademais, o que a análise dos preços do açúcar nas diversas praças do comércio mundial nos mostra é que existia uma hierarquização dos preços deste produto, capitaneada por aqueles que eram aferidos na praça de Amsterdã, seguidos pelo mercado de Londres. Não restam dúvidas que o arrocho dos mercadores destas localidades exercido sobre o mercado de Lisboa resultava em uma replicação desta tensão aos produtores coloniais, que por sua vez conseguiam aprisionar menores rendimentos, constituindo um movimento de pressão global e respostas locais, como já frisado por Dale Tomich. A diferença dos preços mostra que, mesmo com parte das rendas permanecendo na colônia, boa parte destes valores acabava revertida aos grupos mercantis europeus por meio do transporte e comércio. Além disso, a fiscalidade, em suas diversas facetas também produzia ganhos líquidos aos mercadores e ao Estado português, ainda que muitos desses agentes privados e estatais residissem na colônia.

Em síntese, mais do que autonomia x dependência a relação entre metrópole e colônia parece ser marcada por uma forte integração, em que a própria dependência era constituída internamente. 


\section{Fontes e Bibliografia}

\section{Fontes}

\section{Bancos de Dados:}

- PAIVA, A. Banco de Dados dos Contratos do Conselho Ultramarino, 2012;

Este banco de dados foi fruto de projeto preliminar, financiado com Bolsa TT3 FAPESP, sob orientação do prof. Dr. Maximiliano M. Menz, em que foram transcritos em tabelas todos os Contratos de tributos Régios constantes nos Livros de Registro dos Contratos Reais do Conselho Ultramarino (códices 296, 297, 298, 306 e 307), documentação oriunda do Arquivo Histórico Ultramarino, sediado em Lisboa, e que estão microfilmados por ação do Projeto Resgate de Documentação Barão do Rio Branco.

- GPIHG - Global Price and Income History Group

Disponível em http://gpih.ucdavis.edu/index.html (acesso em 04/05/2016). Sediado na Davis University of California, o banco sintetiza dados coletados e publicados individualmente por estudiosos, em períodos distintos, e dá conta de um grande espaço geográfico, estendendo-se por todos os continentes e com dados que variam desde valores nominais de produtos até variações de índices mais contemporâneos, como o PIB. Mantido pelos pesquisadores Leticia Arroyo Abad, (Middlebury College) e Peter H. Lindert, (University of California - Davis), o grupo de membros conta com mais de 20 pesquisadores de diversas universidades em todo o mundo.

- PWR - Prices, Wages and Rents in Portugal

Disponível em http://pwr.dev.simplicidade.com.pt/000000/1/index.htm e http://pwrportugal.ics.ul.pt/ (acessados em 04/05/2016). Este projeto foi iniciado em 2009, financiado pela Fundação Portuguesa para a Ciência e Tecnologia (FCT).Um dos seus objetivos foi o de construir uma base de dados de salários, preços e rendas em Portugal entre 1300 e 1910 cobrindo todo o país. Este esforço contou com a participação de diversos pesquisadores, como Inês Amorim (Universidade do Porto), Leonor Freire Costa (Instituto Técnico de Lisboa), Carlos Faisca (Universidade de Lisboa), Helder Fonseca (Universidade de Évora), António Castro Henriques (Universidade do Porto), 
Conceição Andrade Martins (Universidade de Lisboa), Álvaro Santos Pereira (Simon Fraser University), Jaime Reis (Universidade de Lisboa).

\section{Códices Projeto Resgate de Documentação Histórica Barão do Rio Branco:}

- Arquivo Histórico Ultramarino, Administração Central, Conselho Ultramarino, Assento e Fianças dos Contratos Reais, cód. 296;

O códice 296 corresponde ao primeiro Livro de Registro dos Contratos Reais, compreendendo aos anos de 1671 a 1731 . Possui 100 contratos.

- Arquivo Histórico Ultramarino, Administração Central, Conselho Ultramarino, Assento e Fianças dos Contratos Reais, cód. 297;

O códice 297 corresponde ao segundo Livro de Registro dos Contratos Reais, compreendendo aos anos de 1731 a 1753 . Possui 260 contratos.

- Arquivo Histórico Ultramarino, Administração Central, Conselho Ultramarino, Assento e Fianças dos Contratos Reais, cód. 298.

O códice 298 corresponde ao terceiro Livro de Registro dos Contratos Reais, compreendendo aos anos de 1753 a 1771. Possui 102 contratos.

- Arquivo Histórico Ultramarino, Administração Central, Conselho Ultramarino, Assento e Fianças dos Contratos Reais, cód.306;

O códice 306 corresponde ao quarto Livro de Registro dos Contratos Reais, compreendendo aos anos de 1774 a 1790. Possui 4 contratos.

- Arquivo Histórico Ultramarino, Administração Central, Conselho Ultramarino, Assento e Fianças dos Contratos Reais, cód. 307.

O códice 307 corresponde ao quinto Livro de Registro dos Contratos Reais, compreendendo aos anos de 1792 a 1793. Possui 6 contratos.

\section{Documentos Avulsos Projeto Resgate de Documentação Histórica Barão do Rio}

\section{Branco:}

Arquivo Histórico Ultramarino, Administração Central, Conselho Ultramarino, Bahia, Avulsos; Arquivo Histórico Ultramarino, Administração Central, Conselho Ultramarino, Bahia, Castro Almeida, Avulsos; Arquivo Histórico Ultramarino, Administração Central, Conselho Ultramarino, Bahia, Luísa da Fonseca, Avulsos; Arquivo Histórico Ultramarino, Administração Central, Conselho Ultramarino, Pernambuco, Avulsos; Arquivo Histórico Ultramarino, Administração Central, 
Conselho Ultramarino, Rio de Janeiro, Avulsos; Arquivo Histórico Ultramarino, Administração Central, Conselho Ultramarino, São Paulo, Mendes Gouveia, Avulsos; Arquivo Histórico Ultramarino, Administração Central, Conselho Ultramarino, Contratos do Sal.

Os documentos avulsos das capitanias do Brasil no Projeto Resgate correspondem a toda a documentação referente a determinada capitania e que não faziam parte das coleções de cartográficas e iconográficas ou de códices. Cada capitania, dadas as condições de volume de documentação, teve então seus documentos "separados" em mais de um catálogo (BA: Castro Almeida, Luisa da Fonseca; SP: Mendes Gouveia; RJ: Castro Almeida).

\section{Arquivos}

\section{Lisboa - Portugal}

\section{Arquivo Nacional da Torre do Tombo:}

- Manuscritos do Brasil, Contratos do Brasil, Livro único, 335p.

Diversos contratos, impressos. Nem todos com as cláusulas, mas ainda assim um dos melhores documentos consultados. Contém ainda uma série de leis e foi excelente para confirmar alguns valores de contratos e nomes de contratadores.

\section{Arquivo Histórico do Tribunal de Contas de Portugal:}

- Erário Régio 4253 - Livro de registo das condições dos contratos reais da Repartição da África Ocidental, Maranhão e Baía, 1753-1804.

Contratos com as condições de arrematação, livro composto por diversos contratos "menores", como miunças, gado, dentre outros. Em ordem cronológica.

- Erário Régio 535 - Livro de registo dos termos das arrematações dos contratos feitos no Erário régio

Contratos a partir de 1800; o livro encerra-se por volta de 1807.

- Erário Régio 4254 - Livro de registo das condições dos contratos reais da Repartição da África Ocidental, Maranhão e Baía

- Erário Régio 4132 - Livro de registo dos inventários das rendas reais

Este livro mostrou-se um dos mais importantes na arregimentação dos dados para a pesquisa. Contém Dízima da Alfândega e Dízimos do Rio de Janeiro, bem como 
Dízimos de São Paulo, Entradas de Minas Gerais e Dízimos do Rio Grande de São Pedro do Sul, dentre muitos outros contratos.

- Erário Régio 4106 - Livro de registo das condições dos contratos reais da Repartição da África Oriental, Ásia Portuguesa e Rio de Janeiro

- Erário Régio 4057 - Livros de registo do rendimento da Alfândega do Rio de Janeiro

- Erário Régio 4037 - Livro de registo de instruções para a Governador e Capitão General do Estado da índia e registo de diversas representações respeitantes a contratos do Brasil

Livro começa com ordens para o Estado da Índia, contém informações de diversos contratos e quiproquós que ocorreram nesses períodos, como guerras, notadamente entre França e Inglaterra, o Terramoto, entre outras situações e os desfechos ou pedidos para que se aliviassem/cobrassem os contratos.

- Erário Régio 4045 - Livro de registro de representações pertencentes à capitania do Rio de Janeiro

Correspondências apontam para a remissão de balanços, mas não consta cópia destes no livro.

- Erário Régio 4051 - Livro de representações ao Inspetor do Real Erário 5

Representações endereçadas ao Inspetor do Erário Régio, em que se discutem questões relativas aos contratos de Minas Gerais, assim como também são exibidos alguns balanços e problemas da capitania de São Paulo.

- Erário Régio 4104 - Livro de registo das condições dos contratos reais da Repartição da África Oriental, Ásia Portuguesa e Rio de Janeiro

- Erário Régio 4068 - Livros de Informações da Capitania de MG

Requerimentos de arrematantes de ofícios (escrivão da ouvidoria, tesoureiro, fiscal dos diamantes, vigário, capitães) do governador e capitão geral das MG, contratadores (alguns registros sem valores, apenas indicam o ano do contrato e o contratador), pagamentos de ordenados, depósitos de parte de côngruas de vigários, execuções de inventários.

- Erário Régio 4107 - Livro de registo das condições dos contratos reais da Repartição da África Oriental, Ásia Portuguesa e Rio de Janeiro 


\section{Arquivo Histórico Ultramarino}

REQUERIMENTOS (2) o primeiro, do procurador da Fazenda e Estado da Rainha, desembargador Inácio da Costa Quintela, ao rei D. [João V], solicitando a passagem de Padrão dos juros correspondentes à quantia auferida no transporte de casais das Ilhas para o Brasil, e este ser entregue ao vigário e demais religiosos do Hospício de São João Nepomuceno; o segundo, do contratador do Estanco do sal do Brasil, José Alves de Sá, ao rei [D. José I], solicitando passagem de ordens para que os oficiais da Mesa do Sal deem ao suplicante todos os barcos que forem precisos para o carregamento das quantidades de sal referidas no contrato. Anexo: requerimentos, certidão, contrato (impresso). Obs.: decreto assinado por D. Mariana de Áustria.

- Arquivo Histórico Ultramarino, Conselho Ultramarino, Reino, Cx. 220, pasta 20.

\section{Bibliografia}

ACIOLI, Gustavo. A ascensão do primo pobre: O tabaco na economia colonial na América Portuguesa - um balanço historiográfico. João Pessoa: Saeculum, jan./jun. 2005, (pp. 22-37).

Negócio da Costa Mina e Comércio Atlântico - tabaco, açúcar, ouro e tráfico de escravos: Pernambuco (1654-1760). Tese de doutoramento. USP: São Paulo, 2008.

ALDEN, Dauril. O periodo final do Brasil Colônia, 1750-1808. IN BETHELL, Leslie (org.). História da América Latina: América Latina Colonial. Tradução Mary Amazonas Leite de Barros e Magda Lopes. São Paulo: EDUSP, 2004.

ANTONIL, André João. Cultura e Opulência do Brasil por suas Drogas e Minas (primeira edição, 1711). Introdução de notas por Andréa Mansuy Diniz Silva. (Documenta Uspiana II) São Paulo: Editora da Universidade de São Paulo, 2007.

ARAUJO, Luiz Antônio Silva. Contratos e tributos nas Minas setecentistas: o estudo de um caso - João de Souza Lisboa (1745-1765). Dissertação de mestrado, Niterói, UFF, 2002.

Contratos, comércio e conflitos nas Minas Setecentistas. V Congresso Brasileiro de História Econômica e $6^{\mathrm{a}}$ Conferência Internacional de História de Empresas, 2003, Caxambu; V Congresso Brasileiro de História Econômica e $6^{\text {a }}$ Conferência Internacional de História de Empresas, Niterói, ABPHE, 2003. 
Negociantes e Contratos Régios: o reinado de d. João V. XII Encontro Regional de História da ANPUH, 2006, Niterói; XII Encontro Regional de História da ANPUH, Niterói, Colorgraf, 2006.

- Negociantes e Contratos de Tributos e Direitos Régios na Bahia: notas de pesquisa. IV Encontro Estadual de História, ANPUH/BA, 2008, Vitória da Conquista; Anais Eletrônicos IV Encontro Estadual de História ANPUH-BA, Vitória da Conquista, ANPUH-BA, 2008.

. Fiadores, procuradores e testas de ferro: as redes de negociantes nas arrematações de contratos na América portuguesa no setecentos IN Revista Eletrônica de História do Brasil, v. 10, n. 1 e 2, Jan. - Dez., 2008, (pp. 77-96).

ARRUDA, José Jobson de Andrade. O Brasil no Comércio Colonial. São Paulo: Ática, 1980.

A Produção Econômica, IN SILVA, Maria Beatriz Nizza da, Nova História da Expansão Portuguesa; O Império Luso-Brasileiro (1750 - 1822), vol. VIII, 1992.

O sentido da colônia. Revisitando a crise do antigo sistema colonial no Brasil (1780-1830). IN TENGARRINHA, José (org.). História de Portugal. $2^{\mathrm{a}}$ ed. São Paulo: Editora Unesp, 2001.

O Império Tripolar: Portugal, Angola, Brasil. IN MYRUP, Erik Lars e SCHWARTZ, Stuart (orgs.). O Brasil no império marítimo português. Bauru: Edusc, 2009.

Superlucros: a prova empírica do exclusivo colonial. IN Topoi (Rio J.),v. 15, n. 29, jul./dez. 2014, (pp. 706-718).

AZCUY AMEGHINO, Eduardo. Agricultura, ganadería y diezmos em el bispado de Buenos Aires, 1782-1802: uns comparación infructuosa. IN La Otra Historia. Economia, Estado y sociedad en Río de la Plata Colonial, Buenos Aires: Imago Mundi, 2002.

BARICKMAN, B. J. Um contraponto baiano: açúcar, fumo, mandioca $e$ escravidão no Recôncavo, 1780-1860. Rio de Janeiro: Civilização Brasileira, 2003.

BELlOTTO, Heloísa Liberalli, O Estado Português no Brasil: Sistema Administrativo e Fiscal, IN SILVA, Maria Beatriz Nizza da, Nova História da Expansão Portuguesa; O Império Luso-Brasileiro (1750 - 1822), vol. VIII, Lisboa: Editorial Estampa, 1992.

BETHENCOURT, Francisco, Configurações Políticas e Poderes Locais IN BETHENCOURT, Francisco e CURTO, Diogo Ramada (orgs.). A expansão marítima portuguesa, Lisboa: Edições 70, 2010.

BICALHO, Maria Fernanda e FERLINI, Vera Lúcia. Modos de Governar. Ideias e práticas políticas no Império português. Séculos XVI - XIX. São Paulo: Alameda, 2005. 
BOXER, C. O Império Marítimo Português. São Paulo: Companhia das Letras, 2002.

O Império colonial português (1415-1825). Lisboa: Edições 70, 1981.

A idade do ouro do Brasil: dores do crescimento de uma sociedade colonial, 3 ed., Rio de Janeiro: Nova Fronteira, 2000.

BRAUDEL, Fernand. Civilização Material, economia e capitalismo: séculos XV-XVIII: o tempo do mundo. Volume 3. São Paulo: Martins Fontes, 1996.

Escritos sobre a História. [Tradução J. Guinsburg e Tereza Cristina Silveira da Mota]. - São Paulo: Perspectiva, 2009. - (Debates; 131 / dirigida por J. Guinsburg).

CARDOSO, Ciro Flamarion \& BRIGNOLI, Héctor Pérez. Os Métodos da História. Rio de Janeiro: Graal, 1983.

CARRARA, Ângelo Alves. Fiscalidade e conjunturas financeiras do Estado do Brasil, 1607-1718. Seminário Hermes \& Clio, FEA-USP, São Paulo, 2008.

. Minas e currais: produção rural e mercado interno em Minas Gerais 167-1807. Juiz de Fora: Ed. UFJF, 2007.

Fora: UFJF, 2009.

Receitas e despesas da Real Fazenda no Brasil: século XVII. Juiz de

. Receitas e despesas da Real Fazenda no Brasil: século XVIII. Juiz de Fora: UFJF, 2009.

(org.). A vista ou a prazo: comércio e crédito nas Minas setecentistas.

Juiz de Fora: Ed. UFJF, 2010.

Para uma história dos preços do período colonial: questões de método IN LOCUS: revista de historia. Juiz de Fora: Programa de Pós-Graduação em Historia/Departamento de História, v. 14, n.01, 2008, (pp. 187-217).

SANTIRÓ, Ernest Sánchez (coord.) Guerra e fiscalidade na IberoAmérica colonial (séculos XVII - XIX), Juiz de Fora: Ed. UFJF, 2012.

CARVALHO, Filipe Nunes de, Do Descobrimento à União Ibérica, IN JOHNSON, Harold e SILVA, Maria Beatriz Nizza da, Nova História da Expansão Portuguesa, O império Luso Brasileiro (1500 - 1620), vol. VI, Lisboa: Editorial Estampa, 1992.

CHAMBOULEYRON, Rafael. Escravos do Atlântico Equatorial: tráfico negreiro para o Estado do Maranhão e Pará (século XVII e início do século XVIII). IN Revista Brasileira de História. São Paulo, v.26, nº 52, 2006. (p. 79-114).

COSTA, Bruno Aidar, A Vereda dos Tratos: Fiscalidade e poder regional na capitania de São Paulo, 1723 -1808, tese de doutorado, Universidade de São Paulo, 2012. 
COSTA, Fernando Dores. Crise Financeira, Dívida Pública e Capitalistas. 1796 - 1807. Lisboa, dissertação de mestrado apresentada na Faculdade de Ciências Sociais e Humanas da Universidade Nova de Lisboa. 1992.

COSTA, Leonor Freire; ROCHA, Maria Manuela; SOUSA, Rita Martins de, $O$ ouro do Brasil, 1700-1807, Lisboa, Imprensa Nacional - Casa da Moeda, 2013.

. COSTA, Leonor Freire, LAINS, P., MIRANDA, S. M., História Económica de Portugal, 1143-2010. Lisboa: Esfera dos Livros, 2014.

COSTA, Mário Júlio de Almeida, Forais, IN Dicionário de Historia de Portugal, Porto: Iniciativas Editoriais, vol. 3, 1971.

DOMINGUES, Daniel. The Atlantic Slave to Maranhão, 1680-1846. Volume, Routes and Organization. Slavery and Abolition, 29:4, p. 477-501.

FAORO, Raymundo, Os Donos do Poder: formação do patronato político brasileiro. 5. ed. (1 ed. 1958) - São Paulo: Globo, 2012.

FERLINI, Vera Lúcia do Amaral. A civilização do açúcar. Tudo é História, vol. 88. São Paulo: Editora Brasiliense, 1984.

O município no Brasil colonial e a configuração do poder econômico IN MELLO E SOUZA, Laura de, FURTADO, Júnia Ferreira, BICALHO, Maria Fernanda (orgs.), O governo dos povos, São Paulo: Alameda, 2009

Açúcar e Colonização. São Paulo: Alameda, 2010.

FERNANDES, Valter Lenine. Os contratadores e o contrato da dízima da Alfândega da cidade do Rio de Janeiro (1726-1743). Dissertação de Mestrado apresentada ao Programa de Pós Graduação da Universidade Federal do Estado do Rio de Janeiro, 2010

FRAGOSO, João. Homens de grossa aventura. Rio de Janeiro: Civilização Brasileira, 1998.

e FLORENTINO, Manolo. O arcaísmo como projeto: mercado atlântico, sociedade agrária e elite mercantil em uma economia colonial tardia: Rio de Janeiro, c. 1790 - 1840. Rio de Janeiro: Civilização Brasileira, 2001.

FURTADO, Celso. Formação econômica do Brasil. 34 a ed. São Paulo: Companhia das Letras, 2007.

GALLO, Alberto. Colóquio Internacional Economia e Colonização na Dimensão do Império Português, São Paulo, 30 de Setembro- 3 de Outubro 2008 / Mesa 1. Fiscalidade e Poder Imperial, 30 de Setembro de 2008.

GARCÍA MARÍN, José M., La burocracia castellana bajo los Austrias, Madrid, INAM, 1986.

GIL, Tiago; PESAVENTO, Fábio. Conversa de surdos: subsídio para o debate sobre o mercado interno. VI Jornada Setecentista. Curitiba, 2005. 
GODINHO, Vitorino Magalhães, Mito e Mercadoria, Utopia e prática de navegar: séculos XIII-XVIII, Lisboa: Difel, 1990

. Finanças públicas e estrutura do Estado, IN Dicionário de Historia de Portugal, vol. 3, Porto: Iniciativas Editoriais, 1971.

GOUVÊA, Maria de Fátima Silva. Conselho Ultramarino. IN VAINFAS, Ronaldo (organizador). Dicionário do Brasil colonial (1500-1808). Rio de Janeiro: Objetiva, 2001.

HESPANHA, António Manuel, História das Instituições. Épocas medieval e moderna, Coimbra: Almedina, 1982

Lisboa: Cosmos, 1992

Poder e instituições no Antigo Regime, Lisboa: Cadernos Penélope,

KANTOROWICZ, Eric. Os dois corpos do Rei: Um estudo sobre a teologia política medieval. São Paulo: Companhia das Letras, 1998

LAPA, José Roberto do Amaral. A Bahia e a Carreira da Índia. São Paulo: Companhia Editora Nacional, 1968.

LENK, Wolfgang. Guerra e Pacto Colonial: a Bahia contra o Brasil holandês (1624-1654). São Paulo: Alameda, 2013.

MAGALHÃES, Joaquim Romero, O Algarve Econômico, 1600-1773, Lisboa: Estampa, 1993

. A Fazenda, IN MAGALHÃES, Joaquim Romero (coord.). História de Portugal; No Alvorecer da Modernidade (1480 - 1620), Lisboa: Editorial Estampa, 1997, p. 89.

MARIUTTI, Eduardo Barros. Colonialismo, imperialismo e desenvolvimento econômico europeu. São Paulo: Aderaldo \& Rothschild, 2009. (Estudos Históricos; 68).

MAXWELL, Kenneth. A Devassa da Devassa: a Inconfidência Mineira, BrasilPortugal (1750-1808). Rio de Janeiro: Paz e Terra, 1977.

MENZ, Maximiliano M. Entre impérios: formação do Rio Grande na crise do antigo sistema colonial português (1777 - 1822). São Paulo: Alameda, 2009.

. Capitalismo e Colonização, Relatório Projeto Temático FAPESP, 2012.

Reflexões sobre duas crises econômicas no Império Português (1688-

1770) IN Varia História, Programa de Pós-Graduação em História, Faculdade de Filosofia e Ciências Humanas, Universidade Federal de Minas Gerais - vol. 29 no 49 jan./abr. 2013, (pp. 35-54)

MOREIRA, Alzira Teixeira Leite, Inventário do Fundo Geral do Erário Régio, Arquivo do Tribunal de Contas, Lisboa. 1977. 
NARDI, Jean Baptiste. O Fumo Brasileiro no Período Colonial. São Paulo: Brasiliense, 1996.

NEVES, Guilherme Pereira das, VAINFAS, Ronaldo, Antigo Regime IN VAINFAS, Ronaldo (org.), Dicionário do Brasil Colonial (1500 - 1808), Rio de Janeiro: Objetiva, 2001

NOVAIS, Fernando. Portugal e o Brasil na Crise do Antigo Sistema Colonial. $4^{\mathrm{a}}$ ed. São Paulo: Hucitec, 1986.

Naify, 2005.

Aproximações. Estudos de história e historiografia. São Paulo: Cosac

OLIVAL, Fernanda, COSTA, Fernando Dores, Elites económicas IN LAINS, Pedro e SILVA, Álvaro Ferreira da (orgs.) História Económica de Portugal, 1700 2000, vol. 1 O século XVIII, Lisboa: ICS. Imprensa de Ciências Sociais, $3^{\circ}$ ed., 2005.

PEDREIRA, Jorge. Estrutura Industrial e mercado colonial. Portugal e Brasil (1780-1830). Lisboa: Difel, 1994.

Custos e Tendências Financeiras do Império Português, 1415 - 1822, IN BETHENCOURT, Francisco e CURTO, Diogo Ramada (orgs.) A expansão marítima portuguesa, Lisboa: Edições 70, 2010.

PINTO, Virgílio Noya. O Ouro Brasileiro e o Comércio Anglo-português. São Paulo: Cia. Ed. Nacional, 1979.

PRADO Jr., Caio. Formação do Brasil contemporâneo: Colônia. São Paulo: Brasiliense; Publifolha, (Grandes nomes do pensamento brasileiro), 2000.

PUNTONI, Pedro, "Como coração no meio do corpo": Salvador capital do Estado do Brasil, IN MELLO E SOUZA, Laura de, FURTADO, Júnia Ferreira, BICALHO, Maria Fernanda (orgs.), O governo dos povos, São Paulo: Alameda, 2009.

São Paulo: Alameda, 2013

O Estado do Brasil: Poder e Política na Bahia Colonial 1548-1700.

RIBEIRO JÚNIOR, José. Colonização e Monopólio no Nordeste do Brasileiro. A Companhia Geral de Comércio de Pernambuco e Paraíba. São Paulo: HUCITEC, 1976.

RICUPERO, Rodrigo. A formação da elite colonial: Brasil, c. 1530 - 1630. São Paulo: Alameda, 2009.

SALGADO, Graça (coord.). Fiscais e Meirinhos: a administração no Brasil Colonial. Rio de Janeiro: Nova Fronteira; Brasília: INL, 1985.

SALVADO, João Paulo. O Estanco do Tabaco em Portugal: Contrato Geral e Consórcios Mercantis (1702-1755). IN LUXÁN, Santiago de., Política y Hacienda del Tabaco em los Impérios Ibéricos (siglos XVII-XIX), Madrid: Centro de Estudios Políticos y Constitucionales, 2014, (pp. 133-153) 
SAMPAIO, Antonio Carlos Jucá de. Na encruzilhada do império: hierarquias sociais e conjunturas econômicas no Rio de Janeiro (c.1650-c.1750). 1. Ed. Rio de Janeiro: Arquivo Nacional, 2003.

SANTOS, Diego Pereira. Entre Costas Brasílicas: O tráfico interno de escravos em direitura à Amazônia, c.1778-c.1830. Dissertação de Mestrado apresentada ao Programa de Pós-Graduação em História do Instituto de Filosofia e Ciências Humanas da Universidade Federal do Pará. 2013.

SCHWARTZ, Stuart B. Segredos internos: engenhos e escravos na sociedade colonial, 1550 - 1835. São Paulo: Companhia das Letras, 1988. . Escravos, roceiros e rebeldes. Bauru: EDUSC, 2001

SILVA, Francisco Ribeiro da. Alfândegas lusas em finais de Setecentos: fiscalidade e funcionalismo. IN O litoral em perspectiva histórica (Séc. XVI a XVIII). Porto: Instituto de História Moderna, 2002. (pp. 205-216).

SIMONSEN, Roberto. História Econômica do Brasil (1500 - 1820). São Paulo: Companhia Editora Nacional, 1978.

SUBTIL, José, A administração central da coroa IN MAGALHÃES, Joaquim Romero (coord.). História de Portugal; No Alvorecer da Modernidade (1480 - 1620), Lisboa: Editorial Estampa, 1997.

SUBTIL, José, Governo e Administração, IN HESPANHA, Antônio Manuel, História de Portugal; O Antigo Regime (1620 - 1807), Lisboa: Editorial Estampa, 1998.

TOMAZ, Fernando, As Finanças do Estado Pombalino: 1762-1776, IN Estudos e Ensaios em Homenagem a Vitorino Magalhães Godinho, Lisboa: Livraria Sá da Costa Editora, 1988.

TOMICH, Dale W. Pelo Prisma da Escravidão: Trabalho, Capital e Economia Mundial - tradução Antonio de Pádua Danesi; revisão técnica Rafael de Bivar Marquese - São Paulo: Editora da Universidade de São Paulo, 2011.

VICENS VIVES, J. Estructura administrativa estatal en los siglos XVI y XVII, 1961

VILAR, Pierre. Economía, Derecho, Historia. Barcelona: Editorial Ariel, 1983. 


\section{Anexos}

\section{Tabela 1 - Dízimos da Bahia}

\begin{tabular}{|c|c|c|c|}
\hline Arrematação: & Validade/Período: & Valor do Contrato: & Valor anual: \\
\hline $10 / 06 / 1720$ & $\begin{array}{l}3 \text { anos }-01 / 08 / 1720 \\
-31 / 07 / 1723\end{array}$ & 198.000 .000 & 66.000 .000 \\
\hline $31 / 03 / 1724$ & $\begin{array}{l}3 \text { anos - 01/08/1724 } \\
-31 / 07 / 1727\end{array}$ & 222.000 .000 & 74.000 .000 \\
\hline $11 / 02 / 1726$ & $\begin{array}{l}3 \text { anos - 01/08/1727 } \\
-31 / 07 / 1730 \\
\end{array}$ & 216.150 .000 & 72.050 .000 \\
\hline \multirow[t]{2}{*}{$01 / 01 / 1732$} & $\begin{array}{l}3 \text { anos - 01/08/1733 } \\
-31 / 07 / 1736 \\
\end{array}$ & 203.874.819 & 67.958 .273 \\
\hline & 3 anos - $1730-1733$ & 235.200 .000 & 78.400 .000 \\
\hline $11 / 03 / 1737$ & $\begin{array}{l}3 \text { anos - } 01 / 08 / 1737 \\
-31 / 07 / 1740\end{array}$ & 157.200 .000 & 52.400 .000 \\
\hline 28/06/1740 & $\begin{array}{l}3 \text { anos - } 01 / 08 / 1740 \\
-31 / 07 / 1743\end{array}$ & 157.260 .000 & 52.420 .000 \\
\hline $02 / 04 / 1743$ & $\begin{array}{l}3 \text { anos }-01 / 08 / 1743 \\
-31 / 07 / 1746 \\
\end{array}$ & 157.395 .000 & 52.465 .000 \\
\hline 29/10/1746 & $\begin{array}{l}3 \text { anos - 01/08/1747 } \\
-31 / 07 / 1750\end{array}$ & 150.090 .000 & 50.030 .000 \\
\hline $22 / 09 / 1749$ & $\begin{array}{l}3 \text { anos }-01 / 08 / 1750 \\
-31 / 07 / 1753\end{array}$ & 150.090 .000 & 50.030 .000 \\
\hline $07 / 08 / 1752$ & $\begin{array}{l}3 \text { anos - 01/08/1753 } \\
-31 / 07 / 1756\end{array}$ & 189.600 .000 & 63.200 .000 \\
\hline $19 / 04 / 1757$ & $\begin{array}{l}3 \text { anos - 01/08/1757 } \\
-31 / 07 / 1760\end{array}$ & 150.900 .000 & 50.300 .000 \\
\hline $12 / 01 / 1760$ & $\begin{array}{l}3 \text { anos }-01 / 08 / 1761 \\
-31 / 07 / 1764\end{array}$ & 150.930 .000 & 50.310 .000 \\
\hline $11 / 07 / 1768$ & $\begin{array}{l}1 \text { ano }-01 / 07 / 1768- \\
31 / 06 / 1769\end{array}$ & 50.400 .000 & 50.400 .000 \\
\hline $19 / 07 / 1768$ & $\begin{array}{l}1 \text { ano }-01 / 07 / 1768- \\
31 / 06 / 1769\end{array}$ & 50.400 .000 & 50.400 .000 \\
\hline $13 / 05 / 1769$ & $\begin{array}{l}3 \text { anos - 01/07/1769 } \\
-31 / 06 / 1772\end{array}$ & 159.600 .000 & 53.200 .000 \\
\hline 01/01/1769 & $\begin{array}{l}\text { Findou em } \\
30 / 06 / 1782 \\
\end{array}$ & 180.000 .000 & 60.000 .000 \\
\hline $01 / 01 / 1782$ & $\begin{array}{l}3 \text { anos - 01/07/1782 } \\
-30 / 06 / 1785 \\
\end{array}$ & 228.060 .000 & 76.020 .000 \\
\hline 05/05/1804 & $\begin{array}{l}3 \text { anos - 01/07/1804 } \\
-30 / 06 / 1807\end{array}$ & 165.000 .000 & 55.000 .000 \\
\hline
\end{tabular}

Fontes: PAIVA, A. Banco de Dados dos Contratos do Conselho Ultramarino, 2012; Arquivo Histórico Ultramarino, Administração Central, Conselho Ultramarino, Bahia, Avulsos, Cx. 7, D. 561; Arquivo Histórico Ultramarino, Administração Central, Conselho Ultramarino, Bahia, Avulsos, Cx. 17, D. 1544; Arquivo Histórico Ultramarino, Administração Central, Conselho Ultramarino, Bahia, Avulsos, Cx. 21, D. 1907; Arquivo Histórico Ultramarino, Administração Central, Conselho Ultramarino, Bahia, Avulsos, Cx. 17, D. 1544; Arquivo Histórico Ultramarino, Administração Central, Conselho Ultramarino, Assento e Fianças dos Contratos Reais, cód. 296; Arquivo Histórico Ultramarino, Administração Central, Conselho Ultramarino, Bahia, Avulsos, Cx. 27 D. 2482 ; Arquivo Histórico Ultramarino, Administração Central, Conselho Ultramarino, Bahia, Avulsos, Cx. 85, D. 6945; Arquivo Histórico 
Ultramarino, Administração Central, Conselho Ultramarino, Assento e Fianças dos Contratos Reais, cód. 297; Arquivo Histórico Ultramarino, Administração Central, Conselho Ultramarino, Assento e Fianças dos Contratos Reais, cód. 298; Arquivo Histórico do Tribunal de Contas de Portugal, Erário Régio, liv. 4253; Arquivo Histórico Ultramarino, Administração Central, Conselho Ultramarino, Bahia, Avulsos, Cx. 112, D. 8792; Arquivo Histórico Ultramarino, Administração Central, Conselho Ultramarino, Bahia, Castro Almeida, Avulsos, Cx. 57, D. 10961-10962; Arquivo Histórico do Tribunal de Contas de Portugal, Erário Régio, liv. 535. Arquivo Histórico Ultramarino, Administração Central, Conselho Ultramarino, Mapa Cronológico dos Contratos do Ultramar, cód. 1269 e Arquivo Histórico Ultramarino, Administração Central, Conselho Ultramarino, Bahia, 2a série, cx. 33, doc. 3031 apud CARRARA, Ângelo Alves, Receitas e Despesas da Real Fazenda no Brasil: século XVIII, Juiz de Fora: Ed. UFJF, 2009. p. 213. 
Tabela 2 - Dízima da Alfândega da Bahia

\begin{tabular}{l|l|l|l|}
\hline & & & \\
Arrematação: & Validade/Período: & Valor do Contrato: & Valor anual: \\
\hline $16 / 04 / 1723$ & $\begin{array}{l}3 \text { anos }-13 / 08 / 1723 \\
-31 / 12 / 1726\end{array}$ & 303.900 .000 & 101.300 .000 \\
\hline $10 / 02 / 1726$ & $\begin{array}{l}3 \text { anos }-01 / 01 / 1727 \\
-31 / 12 / 1729\end{array}$ & 304.200 .000 & 101.400 .000 \\
\hline $25 / 02 / 1731$ & $\begin{array}{l}3 \text { anos }-01 / 01 / 1731 \\
-31 / 12 / 1733\end{array}$ & 223.200 .000 & 74.400 .000 \\
\hline $29 / 01 / 1735$ & $\begin{array}{l}3 \text { anos }-01 / 01 / 1736 \\
-31 / 12 / 1738\end{array}$ & 265.230 .000 & 88.410 .000 \\
\hline $13 / 04 / 1739$ & $\begin{array}{l}3 \text { anos }-01 / 01 / 1739 \\
-31 / 12 / 1741\end{array}$ & 288.075 .000 & 96.025 .000 \\
\hline $01 / 04 / 1743$ & $\begin{array}{l}3 \text { anos }-01 / 01 / 1744 \\
-31 / 12 / 1746\end{array}$ & 380.700 .000 & 126.900 .000 \\
\hline $22 / 04 / 1747$ & $\begin{array}{l}3 \text { anos }-01 / 01 / 1748 \\
-31 / 12 / 1750\end{array}$ & 318.000 .000 & 106.000 .000 \\
\hline & $\begin{array}{l}6 \text { anos }-01 / 01 / 1754 \\
-31 / 12 / 1759\end{array}$ & 492.415 .000 & 82.069 .166 \\
\hline
\end{tabular}

Fontes: PAIVA, A. Banco de Dados dos Contratos do Conselho Ultramarino, 2012; Arquivo Histórico Ultramarino, Administração Central, Conselho Ultramarino, Assento e Fianças dos Contratos Reais, cód. 296; Arquivo Histórico Ultramarino, Administração Central, Conselho Ultramarino, Assento e Fianças dos Contratos Reais, cód. 297; Arquivo Histórico Ultramarino, Administração Central, Conselho Ultramarino, Assento e Fianças dos Contratos Reais, cód. 298. 
Tabela 3 - Dízimos de Pernambuco

\begin{tabular}{|c|c|c|c|}
\hline Arrematação: & Validade/Período: & Valor do Contrato: & Valor anual: \\
\hline $01 / 01 / 1720$ & $\begin{array}{l}1 \text { ano }-01 / 08 / 1720- \\
01 / 07 / 1721\end{array}$ & 19.400 .000 & 19.400 .000 \\
\hline $01 / 01 / 1721$ & $\begin{array}{l}1 \text { ano }-01 / 08 / 1721- \\
01 / 07 / 1722\end{array}$ & 22.422 .000 & 22.422 .000 \\
\hline $01 / 01 / 1722$ & $\begin{array}{l}1 \text { ano }-01 / 08 / 1722- \\
01 / 07 / 1723\end{array}$ & 24.820 .000 & 24.820 .000 \\
\hline & 2 anos $-1725-1726$ & 36.000 .000 & 18.000 .000 \\
\hline 20/03/1726 & $\begin{array}{l}3 \text { anos }-01 / 08 / 1726 \\
-31 / 07 / 1729\end{array}$ & 30.000 .000 & 10.000 .000 \\
\hline 29/07/1728 & $\begin{array}{l}3 \text { anos }-01 / 08 / 1729 \\
-31 / 07 / 1732\end{array}$ & 61.500 .000 & 20.500 .000 \\
\hline $07 / 09 / 1731$ & $\begin{array}{l}3 \text { anos }-01 / 08 / 1732 \\
-31 / 07 / 1735\end{array}$ & 61.200 .000 & 20.400 .000 \\
\hline $07 / 11 / 1735$ & $\begin{array}{l}3 \text { anos }-01 / 08 / 1736 \\
-31 / 07 / 1739\end{array}$ & 43.200 .000 & 14.400 .000 \\
\hline $15 / 11 / 1740$ & $\begin{array}{l}3 \text { anos }-01 / 08 / 1741 \\
-31 / 07 / 1744\end{array}$ & 33.780 .000 & 11.260 .000 \\
\hline $09 / 12 / 1743$ & $\begin{array}{l}3 \text { anos }-01 / 08 / 1744 \\
-31 / 07 / 1747\end{array}$ & 43.260 .000 & 14.420 .000 \\
\hline 19/09/1746 & $\begin{array}{l}3 \text { anos }-01 / 08 / 1747 \\
-31 / 07 / 1750 \\
\end{array}$ & 48.000 .000 & 16.000 .000 \\
\hline 19/08/1749 & $\begin{array}{l}3 \text { anos }-01 / 08 / 1750 \\
-01 / 07 / 1753\end{array}$ & 56.415 .000 & 18.805 .000 \\
\hline $14 / 04 / 1753$ & $\begin{array}{l}3 \text { anos }-01 / 08 / 1753 \\
-31 / 07 / 1756\end{array}$ & 53.100 .000 & 17.700 .000 \\
\hline $23 / 11 / 1756$ & $\begin{array}{l}3 \text { anos }-01 / 09 / 1756 \\
-31 / 07 / 1759\end{array}$ & 60.030 .000 & 20.010 .000 \\
\hline $20 / 07 / 1761$ & $\begin{array}{l}3 \text { anos }-01 / 08 / 1761 \\
-31 / 07 / 1764\end{array}$ & 48.000 .000 & 16.000 .000 \\
\hline
\end{tabular}




\begin{tabular}{|l|l|l|l|}
\hline $11 / 06 / 1771$ & $\begin{array}{l}3 \text { anos }-01 / 07 / 1771 \\
-31 / 06 / 1774\end{array}$ & 52.800 .000 & 17.600 .000 \\
\hline $20 / 05 / 1774$ & $\begin{array}{l}3 \text { anos }-01 / 07 / 1774 \\
-30 / 06 / 1777\end{array}$ & 62.700 .000 & 20.900 .000 \\
\hline $01 / 01 / 1777$ & $\begin{array}{l}\text { (3) } \\
-30 / 06 / 1780\end{array}$ & 62.700 .000 & 56.666 .666 \\
\hline $03 / 06 / 1777$ & $\begin{array}{l}3 \text { anos }-01 / 07 / 1780 \\
-30 / 06 / 1783\end{array}$ & 88.185 .000 & 20.900 .000 \\
\hline $29 / 07 / 1780$ & & 211.000 .000 & 70.000 \\
\hline $12 / 07 / 1800$ & 3 anos $-1801-1804$ & 29.395 .000 \\
\hline
\end{tabular}

Fontes: PAIVA, A. Banco de Dados dos Contratos do Conselho Ultramarino, 2012; Arquivo Histórico Ultramarino, Pernambuco, Avulsos, Administração Central, Conselho Ultramarino, Pernambuco, Avulsos, Cx. 32, D. 2969; Arquivo Histórico Ultramarino, Administração Central, Conselho Ultramarino, Assento e Fianças dos Contratos Reais, cód. 296; Arquivo Histórico Ultramarino, Administração Central, Conselho Ultramarino, Assento e Fianças dos Contratos Reais, cód. 297; Arquivo Histórico Ultramarino, Administração Central, Conselho Ultramarino, Pernambuco, Avulsos, Cx. 56, D. 4876; Arquivo Histórico Ultramarino, Administração Central, Conselho Ultramarino, Assento e Fianças dos Contratos Reais, cód. 298; Arquivo Histórico do Tribunal de Contas de Portugal, Erário Régio, liv. 4253; Arquivo Histórico Ultramarino, Administração Central, Conselho Ultramarino, Pernambuco, Avulsos, Cx. 128, D. 9719; Arquivo Histórico do Tribunal de Contas de Portugal, Erário Régio, liv. 4254. Arquivo Histórico Ultramarino, Administração Central, Conselho Ultramarino, Pernambuco, Avulsos, Carta do provedor da Fazenda Real da capitania de Pernambuco, João do Rego Barros, ao rei D. João V, sobre arrematação do contrato dos dízimos reais da dita capitania; anexo 1 doc.; Recife, 20 de agosto de 1725 [cx. 32, doc. 2952] apud CARRARA, Ângelo Alves, Receitas e Despesas da Real Fazenda no Brasil: século XVIII, Juiz de Fora: Ed. UFJF, 2009. p. 243. 
Tabela 4 - Dízima da Alfândega de Pernambuco

\begin{tabular}{|c|c|c|c|}
\hline Arrematação: & Validade/Período: & Valor do Contrato: & Valor anual: \\
\hline $16 / 04 / 1723$ & $\begin{array}{l}3 \text { anos }-01 / 01 / 1724 \\
-31 / 12 / 1726\end{array}$ & 98.400 .000 & 32.800 .000 \\
\hline $17 / 03 / 1727$ & 3 anos - $1728-$ & 122.550 .000 & 40.850 .000 \\
\hline 24/07/1731 & 3 anos & 126.000 .000 & 42.000 .000 \\
\hline $10 / 03 / 1732$ & $\begin{array}{l}3 \text { anos }-01 / 01 / 1732 \\
-31 / 12 / 1734\end{array}$ & 127.200 .000 & 42.400 .000 \\
\hline 29/10/1735 & $\begin{array}{l}3 \text { anos }-01 / 01 / 1736 \\
-31 / 12 / 1738\end{array}$ & 104.100 .000 & 34.700 .000 \\
\hline $13 / 04 / 1739$ & $\begin{array}{l}2 \text { anos }-01 / 01 / 1739 \\
-31 / 12 / 1740\end{array}$ & 17.320 .000 & 8.660 .000 \\
\hline 01/01/1742 & $\begin{array}{l}3 \text { anos }-01 / 01 / 1742 \\
-31 / 12 / 1745\end{array}$ & 144.000 .000 & 48.000 .000 \\
\hline 18/10/1742 & $\begin{array}{l}3 \text { anos }-01 / 01 / 1742 \\
-31 / 12 / 1744\end{array}$ & 144.000 .000 & 48.000 .000 \\
\hline 02/06/1745 & $\begin{array}{l}3 \text { anos }-01 / 01 / 1746 \\
-31 / 12 / 1748\end{array}$ & 127.200 .000 & 42.400 .000 \\
\hline $25 / 02 / 1750$ & $\begin{array}{l}3 \text { anos }-01 / 01 / 1751 \\
-31 / 12 / 1753\end{array}$ & 144.915 .000 & 48.305 .000 \\
\hline \multirow[t]{5}{*}{ 20/12/1754 } & $\begin{array}{l}3 \text { anos }-01 / 01 / 1756 \\
-31 / 12 / 1758\end{array}$ & 165.600 .000 & 55.200 .000 \\
\hline & 3 anos $-1769-1771$ & 112.222 .257 & 37.407 .419 \\
\hline & 3 anos $-1773-1775$ & 398.269 .404 & 132.756 .468 \\
\hline & 3 anos $-1776-1778$ & 188.233 .626 & 62.744 .542 \\
\hline & 3 anos $-1779-1781$ & 264.582 .183 & 88.194 .061 \\
\hline
\end{tabular}




\begin{tabular}{|l|l|l|l|}
\hline & 3 anos - 1782-1784 & 501.626 .493 & 167.208 .831 \\
\hline & 3 anos - 1785-1787 & 445.242 .624 & 148.414 .208 \\
\hline & 3 anos - 1788 - 1790 & 487.429 .509 & 162.476 .503 \\
\hline & 3 anos - 1791 - 1793 & 456.962 .811 & 152.320 .937 \\
\hline & 3 anos - 1794- 1796 & 377.237 .592 & 125.745 .864 \\
\hline & 3 anos - 1797 - 1799 & 388.858 .110 & 129.619 .370 \\
\hline & & & 167.989 .803 \\
\hline
\end{tabular}

Fontes: PAIVA, A. Banco de Dados dos Contratos do Conselho Ultramarino, 2012; Arquivo Histórico Ultramarino, Administração Central, Conselho Ultramarino, Assento e Fianças dos Contratos Reais, cód. 296; Arquivo Histórico Ultramarino, Administração Central, Conselho Ultramarino, Assento e Fianças dos Contratos Reais, cód. 297; Arquivo Histórico Ultramarino, Administração Central, Conselho Ultramarino, Pernambuco, Avulsos, Cx. 79, D. 6544. Biblioteca Nacional do Rio de Janeiro. Divisão de Manuscritos. Relação demonstrativa dos rendimentos da capitania de Pernambuco; 05, 03, 17; coleta feita a partir da folha 14 v.; inclui alguns dados da capitania de Itamaracá; na folha 95 acha-se registrado o "rendimento das sobras das provedorias do Ceará, Paraíba e Rio Grande do Norte". apud CARRARA, Ângelo Alves, Receitas e Despesas da Real Fazenda no Brasil: século XVIII, Juiz de Fora: Ed. UFJF, 2009. p. 255-57. 
Tabela 5 - Dízimos do Rio de Janeiro

\begin{tabular}{|c|c|c|c|}
\hline Arrematação: & Validade/Período: & Valor do Contrato: & Valor anual: \\
\hline & $\begin{array}{l}3 \text { anos }-01 / 03 / 1719 \\
-28 / 02 / 1722\end{array}$ & 61.200 .000 & 20.400 .000 \\
\hline & $\begin{array}{l}3 \text { anos }-01 / 03 / 1722 \\
-28 / 02 / 1725\end{array}$ & 48.000 .000 & 16.000 .000 \\
\hline $12 / 10 / 1725$ & $\begin{array}{l}1 \text { ano }-01 / 03 / 1725- \\
28 / 02 / 1726\end{array}$ & 12.000 .000 & 12.000 .000 \\
\hline $14 / 03 / 1725$ & $\begin{array}{l}3 \text { anos }-01 / 03 / 1726 \\
-28 / 02 / 1729\end{array}$ & 50.400 .000 & 16.800 .000 \\
\hline $18 / 02 / 1728$ & $\begin{array}{l}3 \text { anos }-01 / 03 / 1729 \\
-28 / 02 / 1732\end{array}$ & 56.760 .000 & 18.920 .000 \\
\hline 23/02/1731 & $\begin{array}{l}3 \text { anos }-01 / 03 / 1732 \\
-28 / 02 / 1735\end{array}$ & 57.630 .000 & 19.210 .000 \\
\hline 02/06/1738 & $\begin{array}{l}3 \text { anos }-01 / 03 / 1739 \\
-28 / 02 / 1742 \\
\end{array}$ & 57.615 .000 & 19.205 .000 \\
\hline 26/10/1740 & $\begin{array}{l}3 \text { anos }-01 / 03 / 1742 \\
-28 / 02 / 1745\end{array}$ & 57.625 .000 & 19.208 .333 \\
\hline $12 / 02 / 1744$ & $\begin{array}{l}3 \text { anos }-01 / 03 / 1745 \\
-28 / 02 / 1748\end{array}$ & 67.200 .000 & 22.400 .000 \\
\hline 09/03/1747 & $\begin{array}{l}3 \text { anos }-01 / 03 / 1748 \\
-28 / 02 / 1751\end{array}$ & 84.030 .000 & 28.010 .000 \\
\hline 01/09/1750 & $\begin{array}{l}3 \text { anos }-02 / 03 / 1751 \\
-28 / 02 / 1754\end{array}$ & 72.060 .000 & 28.020 .000 \\
\hline 03/03/1753 & $\begin{array}{l}3 \text { anos }-02 / 03 / 1754 \\
-28 / 02 / 1757\end{array}$ & 84.060 .000 & 24.020 .000 \\
\hline $24 / 02 / 1756$ & $\begin{array}{l}3 \text { anos }-01 / 03 / 1757 \\
-28 / 02 / 1760\end{array}$ & 90.360 .000 & 30.120 .000 \\
\hline \multirow[t]{2}{*}{$27 / 09 / 1758$} & $\begin{array}{l}3 \text { anos }-01 / 03 / 1757 \\
-28 / 02 / 1763\end{array}$ & 82.320 .000 & 27.440 .000 \\
\hline & $\begin{array}{l}3 \text { anos }-01 / 03 / 1763 \\
-28 / 02 / 1766\end{array}$ & 81.999 .999 & 27.333 .333 \\
\hline \multirow[t]{2}{*}{$13 / 08 / 1763$} & $\begin{array}{l}1 \text { ano }-01 / 03 / 1766- \\
28 / 02 / 1767\end{array}$ & 28.400 .000 & 28.400 .000 \\
\hline & $\begin{array}{l}3 \text { anos }-01 / 03 / 1767 \\
-30 / 06 / 1769\end{array}$ & 85.365 .000 & 28.455 .000 \\
\hline $12 / 08 / 1768$ & $\begin{array}{l}3 \text { anos }-01 / 07 / 1769 \\
-30 / 06 / 1772 \\
\end{array}$ & 85.380 .000 & 28.460 .000 \\
\hline 09/12/1769 & $\begin{array}{l}3 \text { anos }-01 / 01 / 1770 \\
-31 / 12 / 1772 \\
\end{array}$ & 86.400 .000 & 28.800 .000 \\
\hline \multirow[t]{4}{*}{ 26/09/1772 } & $\begin{array}{l}3 \text { anos }-01 / 01 / 1773 \\
-31 / 12 / 1775 \\
\end{array}$ & 86.400 .000 & 28.800 .000 \\
\hline & $\begin{array}{l}3 \text { anos }-01 / 01 / 1776 \\
-31 / 12 / 1778\end{array}$ & 86.400 .000 & 28.800 .000 \\
\hline & $\begin{array}{l}3 \text { anos }-01 / 01 / 1779 \\
-31 / 12 / 1781\end{array}$ & 93.200 .000 & 31.066 .666 \\
\hline & $\begin{array}{l}3 \text { anos }-01 / 01 / 1782 \\
-31 / 12 / 1784\end{array}$ & 91.600 .000 & 30.533 .333 \\
\hline
\end{tabular}




\begin{tabular}{|l|l|l|l|}
\hline & $\begin{array}{l}3 \text { anos }-01 / 01 / 1785 \\
-31 / 12 / 1787\end{array}$ & 93.600 .000 & 31.200 .000 \\
\hline $17 / 04 / 1787$ & $\begin{array}{l}3 \text { anos }-01 / 01 / 1788 \\
-31 / 12 / 1790\end{array}$ & 96.600 .000 & 32.200 .000 \\
\hline $04 / 03 / 1790$ & $\begin{array}{l}3 \text { anos }-01 / 01 / 1791 \\
-31 / 12 / 1793\end{array}$ & 127.000 .000 & 42.333 .333 \\
\hline $26 / 06 / 1793$ & $\begin{array}{l}3 \text { anos }-01 / 01 / 1794 \\
-31 / 12 / 1796\end{array}$ & 160.000 .000 & 53.333 .333 \\
\hline & $\begin{array}{l}6 \text { anos }-01 / 01 / 1797 \\
-31 / 12 / 1802\end{array}$ & 366.000 .000 & 61.000 .000 \\
\hline $23 / 11 / 1803$ & $\begin{array}{l}3 \text { anos }-01 / 01 / 1804 \\
-31 / 12 / 1806\end{array}$ & 276.030 .000 & 92.010 .000 \\
\hline
\end{tabular}

Fontes: PAIVA, A. Banco de Dados dos Contratos do Conselho Ultramarino, 2012; Arquivo Histórico Ultramarino, Administração Central, Conselho Ultramarino, Rio de Janeiro, Avulsos, Cx. 10, D. 1131; Arquivo Histórico Ultramarino, Administração Central, Conselho Ultramarino, Rio de Janeiro, Avulsos, Cx. 12, D. 1355; Arquivo Histórico Ultramarino, Administração Central, Conselho Ultramarino, Rio de Janeiro, Avulsos, Cx. 15, D. 1718; Arquivo Histórico Ultramarino, Administração Central, Conselho Ultramarino, Assento e Fianças dos Contratos Reais, cód. 296; Arquivo Histórico Ultramarino, Administração Central, Conselho Ultramarino, Assento e Fianças dos Contratos Reais, cód. 297; Arquivo Histórico Ultramarino, Administração Central, Conselho Ultramarino, Assento e Fianças dos Contratos Reais, cód. 298; Arquivo Histórico do Tribunal de Contas de Portugal, Erário Régio, liv. 4132; Arquivo Histórico Ultramarino, Administração Central, Conselho Ultramarino, Rio de Janeiro, Avulsos, Cx. 129, D. 10263; Arquivo Histórico do Tribunal de Contas de Portugal, Erário Régio, liv. 4106; Arquivo Histórico Ultramarino, Administração Central, Conselho Ultramarino, Assento e Fianças dos Contratos Reais, cód. 306; Arquivo Histórico Ultramarino, Administração Central, Conselho Ultramarino, Assento e Fianças dos Contratos Reais, cód. 307; Arquivo Histórico do Tribunal de Contas de Portugal, Erário Régio, liv. 535. 
Tabela 6 - Dízima da Alfândega do Rio de Janeiro

\begin{tabular}{|c|c|c|c|}
\hline Arrematação: & Validade/Período: & Valor do Contrato: & Valor anual: \\
\hline 26/11/1720 & $\begin{array}{l}3 \text { anos }-01 / 01 / 1721 \\
-31 / 12 / 1723\end{array}$ & 199.803 .600 & 66.601 .200 \\
\hline $16 / 04 / 1723$ & $\begin{array}{l}3 \text { anos }-01 / 01 / 1724 \\
-31 / 12 / 1726\end{array}$ & 291.600 .000 & 97.200 .000 \\
\hline 04/02/1728 & $\begin{array}{l}3 \text { anos }-01 / 01 / 1729 \\
-31 / 12 / 1731\end{array}$ & 366.300 .000 & 122.100 .000 \\
\hline 29/01/1731 & $\begin{array}{l}3 \text { anos }-01 / 01 / 1732 \\
-31 / 12 / 1734\end{array}$ & 322.800 .000 & 107.600.000 \\
\hline 24/10/1733 & $\begin{array}{l}3 \text { anos }-01 / 01 / 1735 \\
-31 / 12 / 1737 \text { (aj.) }\end{array}$ & 480.000 .000 & 160.000 .000 \\
\hline 05/03/1738 & $\begin{array}{l}3 \text { anos }-01 / 01 / 1738 \\
-31 / 12 / 1740\end{array}$ & 584.415 .000 & 194.805 .000 \\
\hline 01/01/1741 & $\begin{array}{l}3 \text { anos }-01 / 01 / 1742 \\
-31 / 12 / 1744\end{array}$ & 625.200 .000 & 208.400 .000 \\
\hline 08/02/1744 & $\begin{array}{l}3 \text { anos }-01 / 01 / 1744 \\
-31 / 12 / 1746\end{array}$ & 628.800 .000 & 209.600.000 \\
\hline 08/05/1747 & $\begin{array}{l}3 \text { anos }-01 / 01 / 1748 \\
-31 / 12 / 1750\end{array}$ & 607.200 .000 & 202.400 .000 \\
\hline $13 / 08 / 1750$ & $\begin{array}{l}3 \text { anos }-01 / 01 / 1751 \\
-31 / 12 / 1753\end{array}$ & 607.200 .000 & 202.400 .000 \\
\hline $31 / 12 / 1762$ & 1762 & 182.391 .051 & 182.391 .051 \\
\hline $31 / 12 / 1763$ & 1763 & 99.107.207 & 99.107.207 \\
\hline $31 / 12 / 1764$ & 1764 & 88.913 .760 & 88.913 .760 \\
\hline $31 / 12 / 1765$ & 1765 & 197.195 .465 & 197.195 .465 \\
\hline $31 / 12 / 1766$ & 1766 & 177.808 .798 & 177.808 .798 \\
\hline $31 / 12 / 1767$ & 1767 & 145.099 .510 & 145.099 .510 \\
\hline $31 / 12 / 1768$ & 1768 & 143.524 .804 & 143.524 .804 \\
\hline $31 / 12 / 1769$ & 1769 & 121.350 .025 & 121.350 .025 \\
\hline $31 / 12 / 1770$ & 1770 & 125.995 .119 & 125.995 .119 \\
\hline $31 / 12 / 1771$ & 1771 & 158.079 .810 & 158.079 .810 \\
\hline $31 / 12 / 1772$ & 1772 & 188.031 .261 & 188.031 .261 \\
\hline $31 / 12 / 1773$ & 1773 & 124.643 .099 & 124.643 .099 \\
\hline $31 / 12 / 1774$ & 1774 & 128.873 .266 & 128.873 .266 \\
\hline $31 / 12 / 1775$ & 1775 & 110.270 .571 & 110.270 .571 \\
\hline $31 / 12 / 1776$ & 1776 & 149.957 .435 & 149.957 .435 \\
\hline
\end{tabular}




\begin{tabular}{|c|c|c|c|}
\hline $31 / 12 / 1777$ & 1777 & 125.178 .554 & 125.178 .554 \\
\hline $31 / 12 / 1778$ & 1778 & 181.521 .547 & 181.521 .547 \\
\hline $31 / 12 / 1779$ & 1779 & 194.061 .657 & 194.061 .657 \\
\hline $31 / 12 / 1780$ & 1780 & 163.276 .929 & 163.276 .929 \\
\hline $31 / 12 / 1781$ & 1781 & 159.603 .001 & 159.603 .001 \\
\hline $31 / 12 / 1782$ & 1782 & 172.568 .821 & 172.568 .821 \\
\hline $31 / 12 / 1783$ & 1783 & 154.496 .863 & 154.496 .863 \\
\hline $31 / 12 / 1784$ & 1784 & 160.078 .489 & 160.078 .489 \\
\hline $31 / 12 / 1785$ & 1785 & 136.918 .143 & 136.918 .143 \\
\hline $31 / 12 / 1786$ & 1786 & 133.024 .458 & 133.024 .458 \\
\hline $31 / 12 / 1787$ & 1787 & 169.800 .180 & 169.800 .180 \\
\hline $31 / 12 / 1788$ & 1788 & 149.020 .163 & 149.020 .163 \\
\hline $31 / 12 / 1789$ & 1789 & 153.993 .739 & 153.993 .739 \\
\hline $31 / 12 / 1790$ & 1790 & 118.500 .398 & 118.500 .398 \\
\hline $31 / 12 / 1791$ & 1791 & 145.159 .224 & 145.159 .224 \\
\hline
\end{tabular}

Fontes: PAIVA, A. Banco de Dados dos Contratos do Conselho Ultramarino, 2012; Arquivo Histórico Ultramarino, Administração Central, Conselho Ultramarino, Assento e Fianças dos Contratos Reais, cód. 296; Arquivo Histórico Ultramarino, Administração Central, Conselho Ultramarino, Assento e Fianças dos Contratos Reais, cód. 297; Arquivo Histórico Ultramarino, Administração Central, Conselho Ultramarino, Rio de Janeiro, Avulsos, Cx. 78, D. 7059; Arquivo Histórico do Tribunal de Contas de Portugal, Erário Régio, liv. 4132; Arquivo Histórico do Tribunal de Contas de Portugal, Erário Régio, liv. 4057; Arquivo Histórico do Tribunal de Contas de Portugal, Erário Régio, liv. 4037. 
Tabela 7 - Dízimos de Minas Gerais

\begin{tabular}{|c|c|c|c|}
\hline Arrematação: & Validade/Período: & Valor do Contrato: & Valor anual: \\
\hline & 1720 & 47.085 .440 & 47.085 .440 \\
\hline & 1721 & 40.082 .117 & 40.082 .117 \\
\hline & 1722 & 40.084 .457 & 40.084 .457 \\
\hline & 1723 & 49.111.646 & 49.111 .646 \\
\hline & 1724 & 49.111.646 & 49.111.646 \\
\hline & 1725 & 74.542 .168 & 74.542 .168 \\
\hline & 1726 & 78.661.245 & 78.661 .245 \\
\hline & 1727 & 79.461.078 & 79.461 .078 \\
\hline 21/02/1727 & $\begin{array}{l}3 \text { anos }-01 / 08 / 1728 \\
-1731\end{array}$ & 96.384 .000 & 32.128 .000 \\
\hline 21/02/1727 & $\begin{array}{l}3 \text { anos }-01 / 08 / 1728 \\
-1731\end{array}$ & 59.712 .000 & 19.904.000 \\
\hline 01/01/1728 & $\begin{array}{l}3 \text { anos }-01 / 08 / 1728 \\
-1731\end{array}$ & 30.720 .000 & 10.240 .000 \\
\hline 27/01/1730 & $\begin{array}{l}3 \text { anos - 01/8/1730- } \\
33\end{array}$ & 133.440 .000 & 44.480 .000 \\
\hline 27/01/1730 & $\begin{array}{l}3 \text { anos - } \\
01 / 08 / 1731-34\end{array}$ & 64.896 .000 & 21.632 .000 \\
\hline 27/01/1730 & $\begin{array}{l}3 \text { anos - } \\
01 / 08 / 1731-34\end{array}$ & 37.248 .000 & 12.416 .000 \\
\hline 29/08/1733 & $\begin{array}{l}3 \text { anos }-01 / 08 / 1734 \\
-31 / 07 / 1737\end{array}$ & 150.528 .000 & 50.176 .000 \\
\hline 29/08/1733 & $\begin{array}{l}3 \text { anos }-01 / 08 / 1734 \\
-31 / 07 / 1737\end{array}$ & 98.304 .000 & 32.768 .000 \\
\hline 29/08/1733 & $\begin{array}{l}3 \text { anos }-01 / 08 / 1734 \\
-31 / 07 / 1737\end{array}$ & 55.322 .750 & 18.440 .917 \\
\hline 22/03/1738 & $\begin{array}{l}3 \text { anos }-01 / 08 / 1738 \\
-31 / 07 / 1741\end{array}$ & 152.064 .000 & 50.688 .000 \\
\hline 22/03/1738 & $\begin{array}{l}3 \text { anos }-01 / 08 / 1738 \\
-31 / 07 / 1741\end{array}$ & 101.376 .000 & 33.792 .000 \\
\hline \multirow[t]{4}{*}{ 22/03/1738 } & $\begin{array}{l}3 \text { anos }-01 / 08 / 1738 \\
-31 / 07 / 1741 \\
\end{array}$ & 55.296 .000 & 18.432 .000 \\
\hline & 1740 & 104.642 .798 & 104.642 .798 \\
\hline & 1741 & 104.427 .332 & 104.427 .332 \\
\hline & 1742 & 104.125 .680 & 104.125 .680 \\
\hline
\end{tabular}




\begin{tabular}{|c|c|c|c|}
\hline & 1743 & 104.125 .680 & 104.125 .680 \\
\hline 21/02/1744 & $\begin{array}{l}3 \text { anos - 01/8/1744- } \\
1747\end{array}$ & 271.296 .000 & 90.432 .000 \\
\hline 19/04/1746 & $\begin{array}{l}3 \text { anos - } \\
01 / 08 / 1747-1750\end{array}$ & 271.296 .000 & 90.432 .000 \\
\hline 19/08/1749 & $\begin{array}{l}3 \text { anos - } \\
01 / 08 / 1750-1753\end{array}$ & 271.488 .000 & 90.496 .000 \\
\hline $17 / 04 / 1753$ & $\begin{array}{l}3 \text { anos }-03 / 08 / 1753 \\
-1756\end{array}$ & 191.050 .000 & 63.683 .333 \\
\hline $17 / 10 / 1755$ & $\begin{array}{l}3 \text { anos - } \\
04 / 08 / 1756-59\end{array}$ & 211.915 .000 & 70.638 .333 \\
\hline 05/10/1758 & $\begin{array}{l}3 \text { anos - } \\
04 / 08 / 1759-62\end{array}$ & 226.800 .000 & 75.600 .000 \\
\hline \multirow[t]{4}{*}{ 18/11/1761 } & $\begin{array}{l}3 \text { anos - } \\
01 / 08 / 1762-65\end{array}$ & 229.230 .000 & 76.510 .000 \\
\hline & 1766 & 82.934 .756 & 82.934 .756 \\
\hline & 1767 & 72.335 .635 & 72.335 .635 \\
\hline & 1765 & 90.079 .268 & 90.079 .268 \\
\hline \multirow[t]{4}{*}{$12 / 11 / 1768$} & $\begin{array}{l}3 \text { anos }-01 / 08 / 1768 \\
-31 / 07 / 1771\end{array}$ & 186.777 .600 & 62.259 .200 \\
\hline & 1771 & 62.962 .547 & 62.962 .547 \\
\hline & 1772 & 62.964 .880 & 62.964 .880 \\
\hline & 1773 & 62.964 .880 & 62.964 .880 \\
\hline \multirow[t]{2}{*}{$01 / 12 / 1773$} & $\begin{array}{l}3 \text { anos }-01 / 08 / 1774 \\
-31 / 07 / 1777\end{array}$ & 186.789 .600 & 62.263 .200 \\
\hline & 1783 & 64.968 .347 & 64.968 .347 \\
\hline 22/03/1777 & $\begin{array}{l}6 \text { anos }-01 / 08 / 1777 \\
-31 / 12 / 1783 \\
\end{array}$ & 388.050 .000 & 64.266 .666 \\
\hline $13 / 05 / 1757$ & $\begin{array}{l}3 \text { anos }-01 / 01 / 1784 \\
-31 / 12 / 1786\end{array}$ & 194.000 .000 & 64.666 .667 \\
\hline \multirow[t]{5}{*}{$02 / 04 / 1787$} & $\begin{array}{l}3 \text { anos }-01 / 01 / 1787 \\
-31 / 12 / 1789 \\
\end{array}$ & 194.000 .000 & 64.666 .667 \\
\hline & 1790 & 75.947 .842 & 75.947 .842 \\
\hline & 1791 & 76.269 .003 & 76.269 .003 \\
\hline & 1792 & 77.067 .299 & 77.067 .299 \\
\hline & 1793 & 72.816 .965 & 72.816 .965 \\
\hline
\end{tabular}




\begin{tabular}{l|l|l|l|}
\hline & 1794 & 72.811 .590 & 72.811 .590 \\
\hline & 1795 & 72.831 .305 & 72.831 .305 \\
\hline & 1796 & 73.104 .303 & 73.104 .303 \\
\hline & 1797 & 73.118 .317 & 73.118 .317 \\
\hline & 1798 & 72.971 .343 & 72.971 .343 \\
\hline & 1799 & 73.525 .164 & 73.525 .164 \\
\hline
\end{tabular}

Fontes: PAIVA, A. Banco de Dados dos Contratos do Conselho Ultramarino, 2012; Arquivo Histórico Ultramarino, Administração Central, Conselho Ultramarino, Assento e Fianças dos Contratos Reais, cód. 296; Arquivo Nacional da Torre do Tombo, Manuscritos do Brasil, Contratos do Brasil; Arquivo Histórico Ultramarino, Administração Central, Conselho Ultramarino, Assento e Fianças dos Contratos Reais, cód. 297; Arquivo Histórico Ultramarino, Administração Central, Conselho Ultramarino, Assento e Fianças dos Contratos Reais, cód. 298; Arquivo Histórico do Tribunal de Contas de Portugal, Erário Régio, liv. 4104; Arquivo Histórico do Tribunal de Contas de Portugal, Erário Régio, liv. 4106. Arquivo Público Mineiro. CC 2001: Mapa geral de todo o rendimento de contratos desta capitania de minas gerais, administrados na mesma, e seus pagamentos nesta provedoria desde o $1^{\circ}$ de janeiro de 1722 até o último de dezembro de 1765 , feita a conta pelo valor do ouro ao tempo em que os remates se obrigaram pelas rematações" apud CARRARA, Ângelo Alves, Receitas e Despesas da Real Fazenda no Brasil: século XVIII, Juiz de Fora: Ed. UFJF, 2009. p. 192-93; Biblioteca Nacional (Lisboa), Coleção Pombalina, vol. 643, doc., n²04: "Relação dos rendimentos gerais desta capitania de minas gerais desde os seus descobrimentos conforme a melhor notícia que se tem alcançado e se pôde averiguar nos mesmos rendimentos" apud PINTO, Virgílio Noya, O ouro brasileiro e o comércio anglo-português: uma contribuição aos estudos da economia atlântica no século XVIII, 2 ed., São Paulo: Ed. Nacional, 1979. 
Tabela 8 - Entradas de Minas Gerais

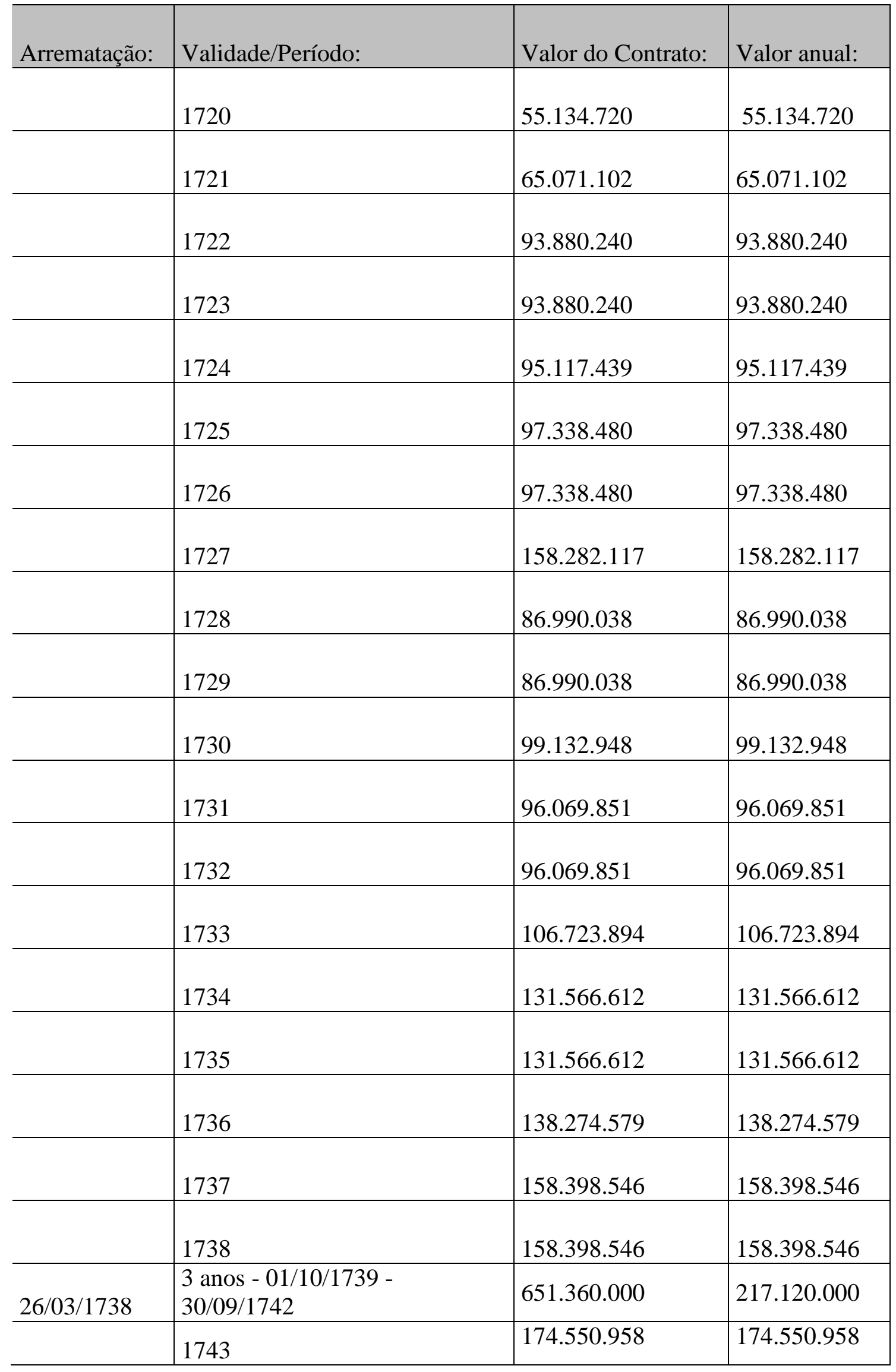




\begin{tabular}{|c|c|c|c|}
\hline & 1744 & 174.550 .958 & 174.550 .958 \\
\hline 20/02/1744 & $\begin{array}{l}3 \text { anos }-01 / 10 / 1745- \\
30 / 09 / 1748\end{array}$ & 691.296 .000 & 230.432 .000 \\
\hline \multirow[t]{5}{*}{ 21/04/1747 } & 3 anos $-01 / 10 / 1748-1751$ & 694.272 .000 & 231.424 .000 \\
\hline & $\begin{array}{l}3 \text { anos }-01 / 01 / 1751- \\
31 / 12 / 1753\end{array}$ & 719.040 .000 & 239.680 .000 \\
\hline & $\begin{array}{l}3 \text { anos }-01 / 01 / 1754- \\
31 / 12 / 1757\end{array}$ & 755.900 .000 & 251.966 .667 \\
\hline & 1757 & 334.510 .879 & 334.510 .879 \\
\hline & 1758 & 114.239 .519 & 114.239 .519 \\
\hline 01/10/1758 & $\begin{array}{l}3 \text { anos }-01 / 01 / 1759- \\
31 / 12 / 1761\end{array}$ & 732.015 .000 & 244.005 .000 \\
\hline \multirow[t]{5}{*}{$18 / 11 / 1761$} & $\begin{array}{l}3 \text { anos }-01 / 01 / 1762- \\
31 / 12 / 1764\end{array}$ & 734.040 .000 & 244.680 .000 \\
\hline & 1765 & 203.438 .420 & 203.438 .420 \\
\hline & 1766 & 172.677 .304 & 172.677 .304 \\
\hline & 1767 & 188.261 .672 & 188.261 .672 \\
\hline & 1768 & 164.964 .545 & 164.964 .545 \\
\hline \multirow[t]{5}{*}{ 01/04/1769 } & $\begin{array}{l}3 \text { anos }-01 / 01 / 1769- \\
31 / 12 / 1771\end{array}$ & 471.300 .000 & 157.100 .000 \\
\hline & 1772 & 164.993 .572 & 164.993 .572 \\
\hline & 1773 & 166.418 .020 & 166.418 .020 \\
\hline & 1774 & 166.946 .852 & 166.946 .852 \\
\hline & 1775 & 155.220 .251 & 155.220 .251 \\
\hline \multirow[t]{7}{*}{ 30/10/1775 } & $\begin{array}{l}6 \text { anos }-01 / 01 / 1776- \\
31 / 12 / 1781\end{array}$ & 944.000 .000 & 157.333 .333 \\
\hline & 1782 & 117.370 .667 & 117.370 .667 \\
\hline & 1783 & 117.370 .666 & 117.370 .666 \\
\hline & 1784 & 117.370 .666 & 117.370 .666 \\
\hline & $\begin{array}{l}3 \text { anos - 01/01/1785 - } \\
31 / 12 / 1787\end{array}$ & 370.000 .000 & 123.333 .333 \\
\hline & $\begin{array}{l}3 \text { anos }-01 / 01 / 1788- \\
31 / 12 / 1790\end{array}$ & 380.000 .000 & 126.666 .667 \\
\hline & 1791 & 134.547 .923 & 134.547 .923 \\
\hline
\end{tabular}




\begin{tabular}{l|l|l|l|}
\hline & 1792 & 129.256 .860 & 129.256 .860 \\
\hline & 1793 & 139.879 .746 & 139.879 .746 \\
\hline & 1794 & 124.401 .222 & 124.401 .222 \\
\hline & 1795 & 118.676 .665 & 118.676 .665 \\
\hline & 1796 & 98.971 .111 & 98.971 .111 \\
\hline & 1797 & 117.008 .549 & 117.008 .549 \\
\hline & 1798 & 101.600 .058 & 101.600 .058 \\
\hline & 1799 & 121.298 .450 & 121.298 .450 \\
\hline
\end{tabular}

Fontes: PAIVA, A. Banco de Dados dos Contratos do Conselho Ultramarino, 2012; Arquivo Histórico Ultramarino, Administração Central, Conselho Ultramarino, Assento e Fianças dos Contratos Reais, cód. 297; Arquivo Histórico Ultramarino, Administração Central, Conselho Ultramarino, Assento e Fianças dos Contratos Reais, cód. 298; Arquivo Histórico do Tribunal de Contas de Portugal, Erário Régio, liv. 4104; Arquivo Histórico do Tribunal de Contas de Portugal, Erário Régio, liv. 4132; Arquivo Histórico do Tribunal de Contas de Portugal, Erário Régio, liv. 4037; Arquivo Histórico do Tribunal de Contas de Portugal, Erário Régio, liv. 4068. Arquivo Público Mineiro. CC 2001: Mapa geral de todo o rendimento de contratos desta capitania de minas gerais, administrados na mesma, e seus pagamentos nesta provedoria desde o $1^{\circ}$ de janeiro de 1722 até o último de dezembro de 1765, feita a conta pelo valor do ouro ao tempo em que os remates se obrigaram pelas rematações" apud CARRARA, Ângelo Alves, Receitas e Despesas da Real Fazenda no Brasil: século XVIII, Juiz de Fora: Ed. UFJF, 2009. p. 192-93; Biblioteca Nacional (Lisboa), Coleção Pombalina, vol. 643, doc., n²04: "Relação dos rendimentos gerais desta capitania de minas gerais desde os seus descobrimentos conforme a melhor notícia que se tem alcançado e se pôde averiguar nos mesmos rendimentos" apud PINTO, Virgílio Noya, O ouro brasileiro e o comércio anglo-português: uma contribuição aos estudos da economia atlântica no século XVIII, 2 ed., São Paulo: Ed. Nacional, 1979. 
Tabela 9 - Dízimos de São Paulo

\begin{tabular}{|c|c|c|c|}
\hline Arrematação: & Validade/Período: & Valor do Contrato: & Valor anual: \\
\hline $13 / 11 / 1726$ & $\begin{array}{l}3 \text { anos }-01 / 08 / 1728 \\
-31 / 07 / 1731\end{array}$ & 33.000 .000 & 11.000 .000 \\
\hline 27/01/1730 & \begin{tabular}{|l}
3 anos - \\
$01 / 08 / 1731-34$
\end{tabular} & 21.015 .000 & 7.005 .000 \\
\hline $15 / 02 / 1738$ & \begin{tabular}{|l|}
3 anos - \\
$01 / 08 / 1738-1741$
\end{tabular} & 30.150 .000 & 10.050 .000 \\
\hline $15 / 11 / 1740$ & \begin{tabular}{|l|}
3 anos - \\
$01 / 08 / 1741-1744$
\end{tabular} & 30.180 .000 & 10.060 .000 \\
\hline 30/03/1743 & $\begin{array}{l}3 \text { anos - } \\
01 / 08 / 1744-1747\end{array}$ & 36.015 .000 & 12.005 .000 \\
\hline 22/04/1747 & \begin{tabular}{|l}
3 anos - \\
$01 / 08 / 1747-1750$
\end{tabular} & 31.800 .000 & 10.600 .000 \\
\hline 27/09/1749 & 3 anos - & 32.445 .000 & 10.815 .000 \\
\hline $02 / 03 / 1753$ & 3 anos & 32.460 .000 & 10.820 .000 \\
\hline 08/01/1756 & $\begin{array}{l}3 \text { anos }-01 / 08 / 1757 \\
-31 / 07 / 1760\end{array}$ & 32.835 .000 & 10.945 .000 \\
\hline $12 / 01 / 1760$ & $\begin{array}{l}3 \text { anos }-1 / 08 / 1761- \\
31 / 07 / 1764\end{array}$ & 32.865 .000 & 10.955 .000 \\
\hline \multirow[t]{8}{*}{ 28/07/1763 } & 3 anos $-01 / 08 / 1764$ & 34.800 .000 & 11.600 .000 \\
\hline & $\begin{array}{l}1 \text { ano }-01 / 08 / 1764- \\
31 / 07 / 1765\end{array}$ & 7.625 .000 & 7.625 .000 \\
\hline & $\begin{array}{l}1 \text { ano }-01 / 08 / 1765- \\
31 / 07 / 1766\end{array}$ & 7.625 .000 & 7.625 .000 \\
\hline & $\begin{array}{l}1 \text { ano }-01 / 08 / 1766- \\
31 / 07 / 1767\end{array}$ & 7.625 .000 & 7.625 .000 \\
\hline & $\begin{array}{l}1 \text { ano }-01 / 08 / 1767- \\
30 / 06 / 1768\end{array}$ & 7.000 .000 & 7.000 .000 \\
\hline & $\begin{array}{l}1 \text { ano - 01/07/1768- } \\
30 / 06 / 1769\end{array}$ & 7.910 .000 & 7.910 .000 \\
\hline & $\begin{array}{l}1 \text { ano - 01/07/1769- } \\
30 / 06 / 1770\end{array}$ & 8.112 .000 & 8.112 .000 \\
\hline & $\begin{array}{l}1 \text { ano }-01 / 07 / 1770- \\
30 / 06 / 1771\end{array}$ & 8.112 .000 & 8.112 .000 \\
\hline $12 / 08 / 1768$ & $\begin{array}{l}3 \text { anos }-01 / 07 / 1769 \\
-30 / 06 / 1772 \\
\end{array}$ & 33.000 .000 & 11.000 .000 \\
\hline 01/01/1773 & $\begin{array}{l}3 \text { anos }-01 / 08 / 1773 \\
-31 / 07 / 1776\end{array}$ & 33.000 .000 & 11.000 .000 \\
\hline $12 / 06 / 1771$ & $\begin{array}{l}3 \text { anos }-01 / 07 / 1771 \\
-30 / 06 / 1774\end{array}$ & 24.799 .998 & 8.266 .666 \\
\hline $01 / 06 / 1774$ & $\begin{array}{l}3 \text { anos }-01 / 07 / 1774 \\
-30 / 06 / 1777\end{array}$ & 26.400 .000 & 8.800 .000 \\
\hline 02/06/1777 & $\begin{array}{l}3 \text { anos }-01 / 07 / 1777 \\
-30 / 06 / 1780 \\
\end{array}$ & 32.100 .000 & 10.700 .000 \\
\hline
\end{tabular}




\begin{tabular}{l|l|l|l|}
\hline & $\begin{array}{l}3 \text { anos }-01 / 07 / 1780 \\
-30 / 06 / 1783\end{array}$ & 41.500 .000 & 13.833 .333 \\
\hline $28 / 04 / 1783$ & $\begin{array}{l}3 \text { anos }-01 / 07 / 1783 \\
-30 / 06 / 1786\end{array}$ & 46.510 .000 & 15.503 .333 \\
\hline $07 / 04 / 1786$ & $\begin{array}{l}3 \text { anos }-01 / 07 / 1786 \\
-30 / 06 / 1789\end{array}$ & 61.100 .000 & 20.366 .666 \\
\hline $17 / 04 / 1789$ & $\begin{array}{l}3 \text { anos }-01 / 07 / 1789 \\
-30 / 06 / 1792\end{array}$ & 68.500 .000 & 22.833 .333 \\
\hline $01 / 07 / 1792$ & $\begin{array}{l}3 \text { anos }-01 / 07 / 1792 \\
-30 / 06 / 1795\end{array}$ & 74.700 .000 & 24.900 .000 \\
\hline $3 / 12 / 1795$ & $\begin{array}{l}3 \text { anos }-01 / 07 / 1795 \\
-30 / 06 / 1798\end{array}$ & 76.000 .000 & 25.333 .333 \\
\hline $\begin{array}{l}3 \text { anos }-01 / 07 / 1801 \\
-30 / 06 / 1804\end{array}$ & 89.200 .000 & 29.733 .333 \\
\hline $21 / 04 / 1804$ & $\begin{array}{l}3 \text { anos }-01 / 07 / 1804 \\
-30 / 06 / 1807\end{array}$ & 119.000 .000 & 39.666 .667 \\
\hline $18 / 03 / 1807$ & $\begin{array}{l}3 \text { anos }-01 / 07 / 1807 \\
-30 / 06 / 1810\end{array}$ & 120.000 .000 & 40.000 .000 \\
\hline
\end{tabular}

Fontes: PAIVA, A. Banco de Dados dos Contratos do Conselho Ultramarino, 2012; Arquivo Histórico Ultramarino, Administração Central, Conselho Ultramarino, Assento e Fianças dos Contratos Reais, cód. 296; Arquivo Histórico Ultramarino, Administração Central, Conselho Ultramarino, Assento e Fianças dos Contratos Reais, cód. 297; Arquivo Histórico Ultramarino, Administração Central, Conselho Ultramarino, São Paulo, Mendes Gouveia, Avulsos, Cx. 13, D. 1325; Arquivo Histórico Ultramarino, Administração Central, Conselho Ultramarino, São Paulo, Mendes Gouveia, Avulsos, Cx. 66, D. 5090; Arquivo Histórico Ultramarino, Administração Central, Conselho Ultramarino, Assento e Fianças dos Contratos Reais, cód. 298; Arquivo Histórico Ultramarino, Administração Central, Conselho Ultramarino, São Paulo, Mendes Gouveia, Avulsos, Cx. 22, D. 2116; Arquivo Histórico Ultramarino, Administração Central, Conselho Ultramarino, São Paulo, Mendes Gouveia, Avulsos, Cx. 23, D. 2230; Arquivo Histórico do Tribunal de Contas de Portugal, Erário Régio, liv. 4132; Arquivo Histórico Ultramarino, Administração Central, Conselho Ultramarino, São Paulo, Mendes Gouveia, Avulsos, Cx. 66, D. 5090; Arquivo Histórico Ultramarino, Administração Central, Conselho Ultramarino, São Paulo, Mendes Gouveia, Avulsos, Cx. 29, D. 2631; Arquivo Histórico Ultramarino, Administração Central, Conselho Ultramarino, São Paulo, Mendes Gouveia, Avulsos, Cx. 30, D. 2680; Arquivo Histórico Ultramarino, Administração Central, Conselho Ultramarino, São Paulo, Mendes Gouveia, Avulsos, Cx. 43, D. 3480; Arquivo Histórico do Tribunal de Contas de Portugal, Erário Régio, liv. 4045; Arquivo Histórico do Tribunal de Contas de Portugal, Erário Régio, liv. 4051; Arquivo Histórico Ultramarino, Administração Central, Conselho Ultramarino, São Paulo, Mendes Gouveia, Avulsos, Cx. 56, D. 4231; Arquivo Histórico Ultramarino, Administração Central, Conselho Ultramarino, São Paulo, Mendes Gouveia, Avulsos, Cx. 53, D. 4101; Arquivo Histórico Ultramarino, Administração Central, Conselho Ultramarino, São Paulo, Mendes Gouveia, Avulsos, Cx. 63, D. 4811; Arquivo Histórico do Tribunal de Contas de Portugal, Erário Régio, liv. 4106; Arquivo Histórico do Tribunal de Contas de Portugal, Erário Régio, liv. 535 . 
Tabela 10 - Dízimos do Rio Grande de São Pedro do Sul

\begin{tabular}{l|l|l|l|}
\hline Arrematação: & Validade/Período: & Valor do Contrato: & Valor anual: \\
\hline & $\begin{array}{l}3 \text { anos }-01 / 08 / 1760 \\
-31 / 07 / 1763\end{array}$ & 99.000 .000 & 3.300 .000 \\
\hline $18 / 04 / 1771$ & $\begin{array}{l}3 \text { anos }-01 / 07 / 1771 \\
-31 / 12 / 1774\end{array}$ & 23.333 .335 & 6.666 .666 \\
\hline $17 / 06 / 1786$ & $\begin{array}{l}3 \text { anos }-01 / 01 / 1787 \\
-31 / 12 / 1789\end{array}$ & 24.000 .000 & 8.000 .000 \\
\hline $29 / 08 / 1789$ & $\begin{array}{l}1 \text { ano }-01 / 01 / 1790- \\
31 / 12 / 1790\end{array}$ & 8.110 .000 & 8.110 .000 \\
\hline & $\begin{array}{l}3 \text { anos }-01 / 01 / 1791 \\
-31 / 12 / 1793\end{array}$ & 26.300 .000 & 8.766 .667 \\
\hline $06 / 07 / 1790$ & $\begin{array}{l}3 \text { anos }-01 / 01 / 1794 \\
-31 / 12 / 1796\end{array}$ & 27.000 .000 & 9.000 .000 \\
\hline $17 / 07 / 1793$ & $\begin{array}{l}9 \text { anos }-01 / 01 / 1797 \\
-31 / 12 / 1805\end{array}$ & 84.000 .000 & 9.333 .333 \\
\hline & $\begin{array}{l}3 \text { anos }-01 / 01 / 1806 \\
-31 / 12 / 1808\end{array}$ & 40.200 .000 & 13.400 .000 \\
\hline
\end{tabular}

Fontes: PAIVA, A. Banco de Dados dos Contratos do Conselho Ultramarino, 2012; Arquivo Histórico do Tribunal de Contas de Portugal, Erário Régio, liv. 4132; Arquivo Histórico do Tribunal de Contas de Portugal, Erário Régio, liv. 4104; Arquivo Histórico do Tribunal de Contas de Portugal, Erário Régio, liv. 4106; Arquivo Histórico do Tribunal de Contas de Portugal, Erário Régio, liv. 4045; Arquivo Histórico do Tribunal de Contas de Portugal, Erário Régio, liv. 4107. 